\title{
ANÁLISE TÉRMICA E DINÂMICA DO SISTEMA DE FREIO A DISCO DE VEÍCULOS COMERCIAIS PESADOS
}

\author{
Silvia Faria Iombriller
}

Tese apresentada à Escola de Engenharia de São Carlos, da Universidade de São Paulo, como parte dos requisitos para obtenção do título de Doutor em Engenharia Mecânica.

Orientador: Prof. Dr. Antônio Carlos Canale

São Carlos

2002 
À Deus, por Seu amor e Sua constante presença, orientando minha vida e este trabalho.

"Confia no Senhor de todo o teu coração, e não te estribes no teu próprio entendimento."

Provérbios 3:5

Bíblia Sagrada 
Ao meu marido Marcos,

por caminhar e sonhar comigo,

pelas palavras de incentivo,

olhares e sorrisos repletos de amor.

Aos meu pais, Luisa e Antônio, pelo colo sempre pronto, pelo amor e carinho.

Aos meus irmãos, Edson e Sorai, por sua presença e carinho.

Às minhas sobrinhas, Anna e Gabriella, pela ternura de seus abraços. 


\section{AGRADECIMENTOS}

Ao Prof. Dr. Antônio Carlos Canale, pela amizade, orientação e apoio no desenvolvimento deste trabalho.

À Prof ${ }^{\mathrm{a}} \mathrm{Dr}^{\mathrm{a}}$. Lauralice Canale, pelo apoio e compreensão durante a elaboração do trabalho final.

Ao Conselho Nacional de Pesquisa - CNPq, pela bolsa de estudo concedida.

Ao Prof. Dr. Josmar Pagliuso, pela orientação e apoio.

Aos colegas e professores do Departamento de Engenharia de Materiais, Aeronáutica e Automobilística da EESC - USP, pelo incentivo.

À Ana Paula Bueno Bardelotte da secretaria de pós-graduação, à Helena Peres da biblioteca central, e demais funcionários da Escola de Engenharia de São Carlos, pela boa vontade em ajudar sempre.

A Camilo Adas, Fernando Dusi, Dirceu Fernandes, César Ferreira, Oswaldir Torres, Edmilson Costa, Francisco Magrini Filho, Anderson Silva, Júlio Beluzo, Carlos, Idélcio e demais colegas da DaimlerChrysler do Brasil, pelo apoio, amizade e grande ajuda na execução deste trabalho.

A Fernando Andrade, pelo apoio, amizade e por acreditar neste trabalho e nas propostas de trabalhos futuros.

A Paulo Ávila, por sua importante colaboração no processo de aquisição de dados durante os testes, e sua imensa boa vontade em ajudar sempre.

À Fras-Le, e seus colaboradores, pela realização dos testes em dinamômetro realizados em seu laboratório.

À DaimlerChrysler do Brasil, pela realização dos testes com seus veículos e pelo seu incentivo a este trabalho de pesquisa. 
SUMÁRIO

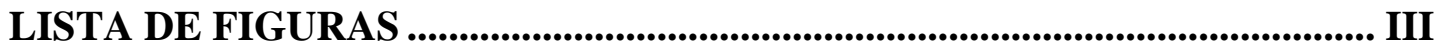

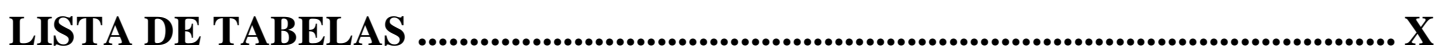

LISTA DE ABREVIATURAS E SIGLAS .....................................................XI

LISTA DE SÍMBOLOS...................................................................................... XII

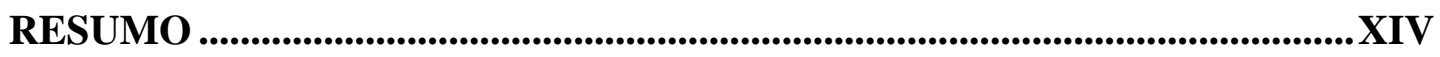

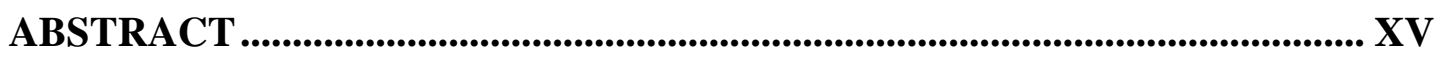

1. INTRODUÇÃ

2. ASPECTOS DA UTILIZAÇÃO DO SISTEMA DE FREIOS............................. 7

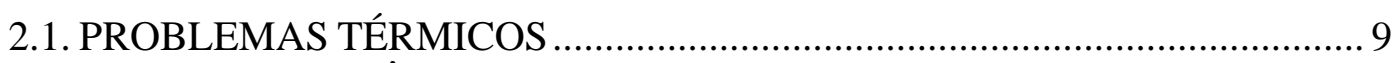

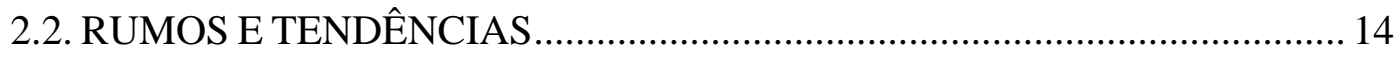

3. REVISÃO BIBLIOGRÁFICA........................................................... 16

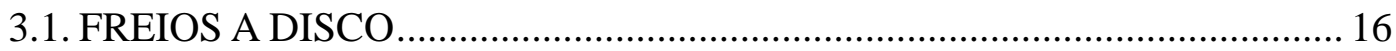

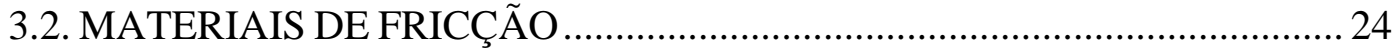

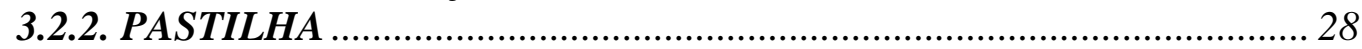

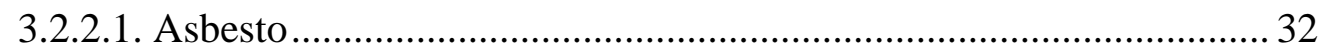

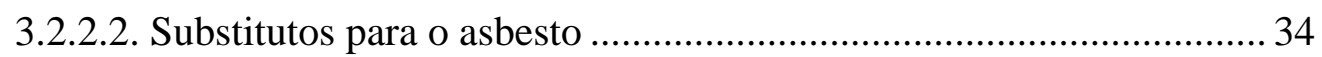

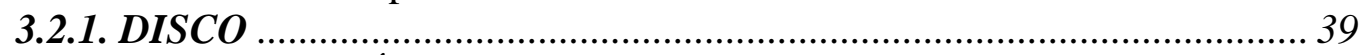

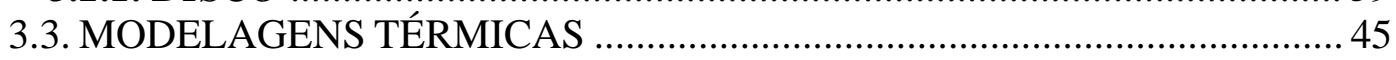

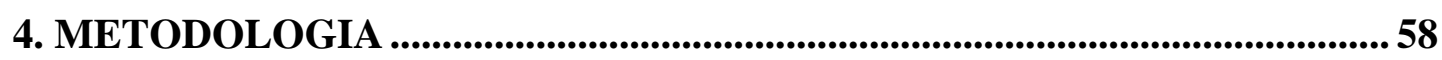

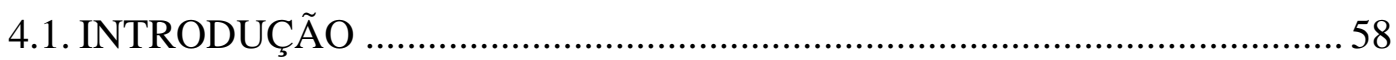

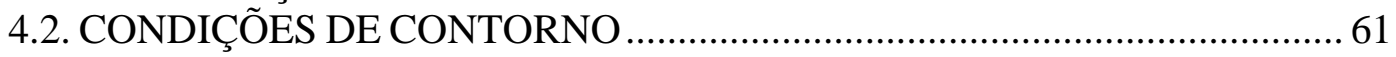

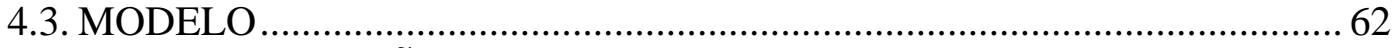

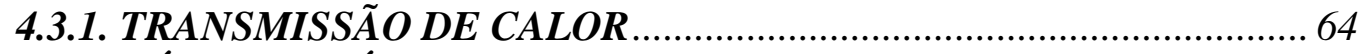

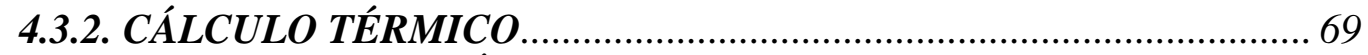

4.3.3. PROGRAMA DE CÁLCULO PARA SIMULAÇÃO VEICULAR ........ 73

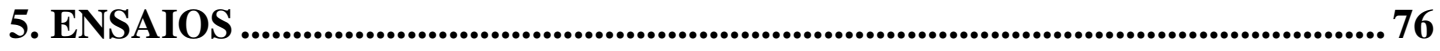

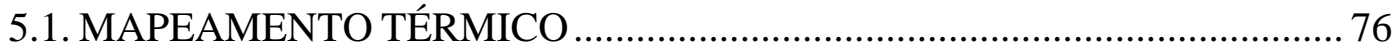

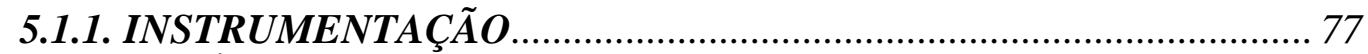

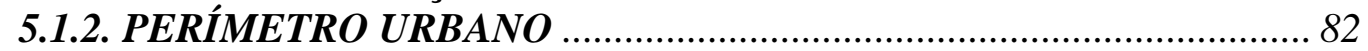

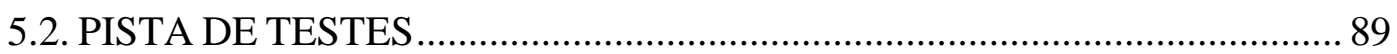

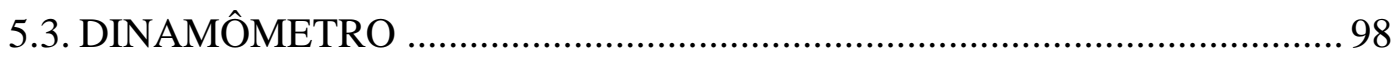

6. APLICAÇÃO DO PROGRAMA COMPUTACIONAL ................................. 105

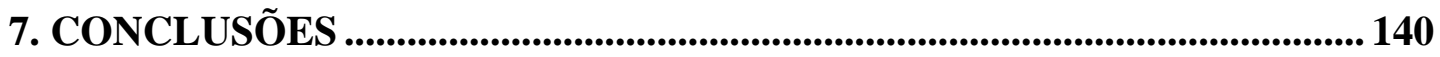

8. PROPOSTAS DE TRABALHOS FUTUROS ................................................. 142 
9. REFERÊNCIAS BIBLIOGRÁFICAS .......................................................... 144

10. BIBLIOGRAFIA CONSULTADA........................................................... 156

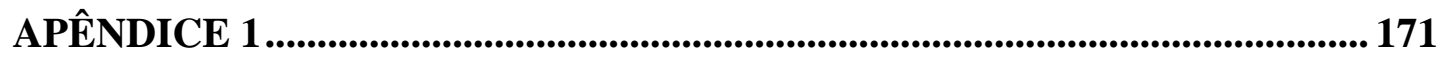

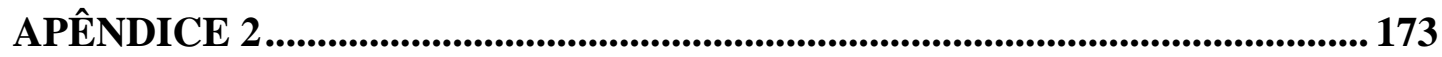

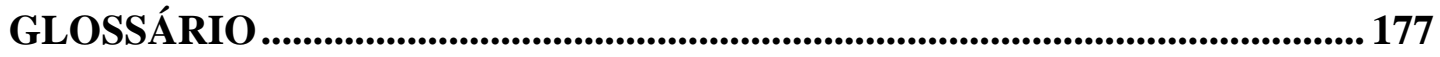




\section{LISTA DE FIGURAS}

Figura 1 - Mudança na distorção térmica em relação ao tempo - YEVTUSHENKO

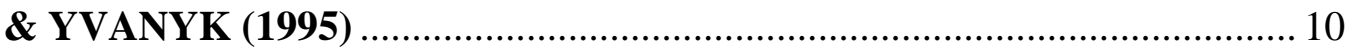

Figura 2 - Eficiência variando com a histerese - GOHRING \& VON GLASNER (1990)

Figura 3 - Desaceleração em relação ao tempo enquanto o veículo faz uma curva -

GOHRING \& VON GLASNER (1990)

Figura 4 - Tempo de resposta de um freio a disco e outro a tambor, em relação ao

valor de requisito - PAUL \& BUENO JR. (1999)

Figura 5 - Procedimento de previsão de desgaste da pastilha. MINEGISHI,

SHIMIZU, WAKAMATSU \& YOSHIMO (1984)

Figura 6 - Fluxograma da análise térmica - GARRO, GAVELLO \& ROSSI (1981)

Figura 7 - Sistema de projeto integrado para discos de freio - FUKANO \& MATSUI (1986)

Figura 8 - Sistema de simulação - GOHRING \& VON GLASNER (1988)........... 51

Figura 9 - Modelagem térmica do sistema de freios - HIGHLEY (1971)............... 53

Figura 10 - Algoritmo termomecânico - BENSEDDIQ, WEICHERT,

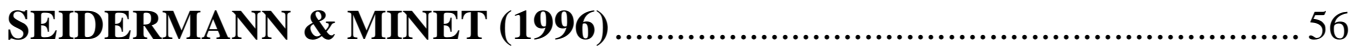

Figura 11 - Modelagem térmica do sistema de freios - LIMPERT (1992) ............. 57

Figura 12 -. Variáveis envolvidas nas condições que influenciam a temperatura na frenagem - CANALE, IOMBRILLER, ADAS \& ANDRADE (1999). 62

Figura 13 - Frenagem de emergência - Comparativo qualitativo da variação de temperatura - RITZ, ADAS \& FRANCISCO (1995)

Figura 14 - Variação da temperatura do disco ao final de uma frenagem com várias aplicações do freio - NEWCOMB (1960) 66

Figura 15 - Frenagem contínua - Comparativo qualitativo da variação da temperatura - RITZ, ADAS \& FRANCISCO (1995) 66

Figura 16 - Diagrama do programa computacional utilizado. 73 


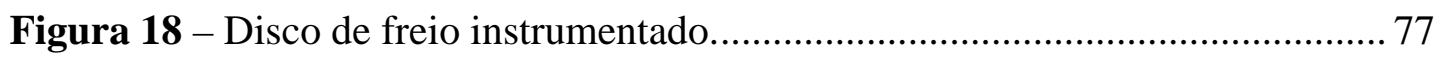

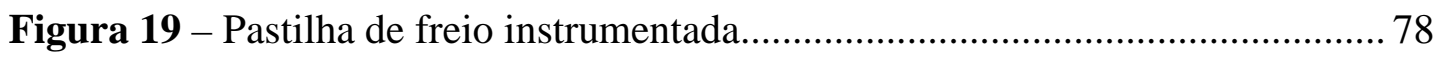

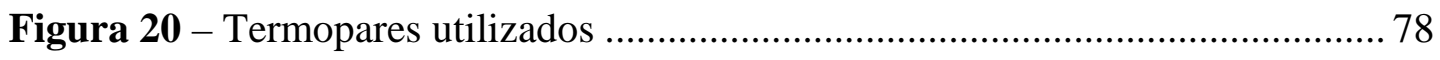

Figura 21 - Instrumentação do cubo de roda ........................................................... 79

Figura 22 - Montagem do eixo instrumentado ...................................................... 79

Figura 23 - Instalação do eixo instrumentado no veículo. ........................................ 80

Figura 24 - Vista do coletor rotativo acoplado ao cubo da roda no veículo.............. 80

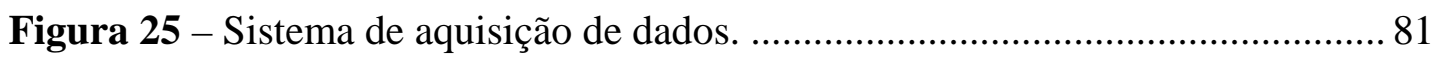

Figura 26 - Temperatura nos discos de freio em perímetro urbano. ........................ 83

Figura 27 - Temperatura em diferentes pontos instrumentados no disco dianteiro direito (face interna do disco) em perímetro urbano......................................... 83

Figura 28 - Temperatura em diferentes pontos instrumentados no disco traseiro esquerdo (face interna do disco) em perímetro urbano.

Figura 29 - Curva de tendência da temperatura do disco de freio em perímetro urbano.

Figura 30 - Curva de tendência das temperaturas dos discos de freio em perímetro urbano - eixo dianteiro.

Figura 31 - Curva de tendência das temperaturas dos discos de freio em perímetro urbano - eixo traseiro. 86

Figura 32 - Curva de tendência das temperaturas do disco de freio em perímetro urbano -eixo traseiro - lado direito.

Figura 33 - Curva de tendência das temperaturas das pastilhas em perímetro urbano.

Figura 34 - Curva de tendência das temperaturas dos pneus em perímetro urbano. 88

Figura 35 - Curva de tendência das temperaturas das pistas dos retentores em perímetro urbano. 88

Figura 36 - Pista de testes da TRW em Limeira. 89

Figura 37 - Comparativo do sentido da pista de testes - temperatura dos discos de freio.

Figura 38 - Comparativo do sentido da pista de testes - temperatura das pastilhas. 91

Figura 39- Comparativo do sentido da pista de testes - temperatura dos pneus...... 92

Figura 40 - Fixação do sistema de ventilação forçada. 
Figura 41 - Vista dos dutos de ventilação forçada................................................. 93

Figura 42 - Dutos de ventilação forçada direcionados aos discos.

Figura 43 - Comparativo das temperaturas atingidas no disco de freio dianteiro considerando o efeito da ventilação forçada.

Figura 44 - Comparativo das temperaturas atingidas no disco de freio traseiro considerando o efeito da ventilação forçada.

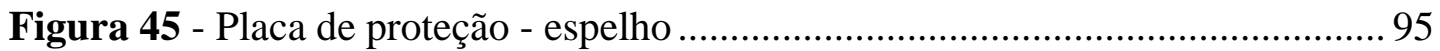

Figura 46 - Espelho instalado em uma das rodas do veículo. 95

Figura 47 - Comparativo das temperaturas atingidas no disco de freio dianteiro considerando o efeito do espelho.

Figura 48 - Comparativo das temperaturas atingidas no disco de freio traseiro considerando o efeito do espelho. 96

Figura 49 - Vista do carregamento do veículo. 97

Figura 50 - Comparativo das temperaturas atingidas no disco de freio dianteiro considerando a variação de carga.....

Figura 51 - Comparativo das temperaturas atingidas no disco de freio traseiro considerando a variação de carga. 98

Figura 52 - Dinamômetros inerciais no laboratório de testes da Fras-le. 99

Figura 53 - Sistema de freio a disco montado em dinamômetro inercial. 100

Figura 54 - Volantes do dinamômetro inercial. 100

Figura 55 - Disco de freio sob elevadas temperaturas. 101

Figura 58 - Imagens da câmera de infra-vermelho de um quadrante do disco de freio no dinamômetro inercial.

Figura 59 - Temperatura no disco de freio traseiro, com fator de freio variável, para diferentes velocidades iniciais de frenagem. 106

Figura 60 - Fator de freio no eixo traseiro, para diferentes velocidades iniciais de frenagem.

Figura 61 - Fator de freio no eixo dianteiro, para diferentes velocidades iniciais de frenagem.

Figura 62 - Força de frenagem no eixo dianteiro, para diferentes velocidades iniciais de frenagem. 108 
Figura 63 - Desaceleração do veículo para diferentes velocidades iniciais de frenagem

Figura 64 - Coeficiente de aderência dos pneus.

Figura 65 - Escorregamento parcial do eixo dianteiro, para diferentes velocidades iniciais de frenagem.

Figura 66 - Escorregamento parcial do eixo traseiro, para diferentes velocidades iniciais de frenagem.

Figura 67 - Coeficiente de aderência no eixo dianteiro, para diferentes velocidades iniciais de frenagem.

Figura 68 - Coeficiente de aderência no eixo traseiro, para diferentes velocidades iniciais de frenagem.

Figura 69 - Força de frenagem no eixo dianteiro, considerando diferentes fatores de freio para a velocidade inicial de frenagem de $60 \mathrm{~km} / \mathrm{h}$.

Figura 70 - Força de frenagem no eixo traseiro, considerando diferentes fatores de freio para a velocidade inicial de frenagem de $60 \mathrm{~km} / \mathrm{h}$.

Figura 71 - Escorregamento parcial do eixo dianteiro, considerando diferentes fatores de freio para a velocidade inicial de frenagem de $60 \mathrm{~km} / \mathrm{h}$.

Figura 72 - Escorregamento parcial do eixo traseiro, considerando diferentes fatores de freio para a velocidade inicial de frenagem de $60 \mathrm{~km} / \mathrm{h}$.

Figura 73 - Coeficiente de aderência no eixo dianteiro, considerando diferentes fatores de freio para a velocidade inicial de frenagem de $60 \mathrm{~km} / \mathrm{h}$.

Figura 74 - Coeficiente de aderência no eixo traseiro, considerando diferentes fatores de freio para a velocidade inicial de frenagem de $60 \mathrm{~km} / \mathrm{h}$.

Figura 75 - Fator de freio no eixo dianteiro, para a velocidade inicial de frenagem de $80 \mathrm{~km} / \mathrm{h}$

Figura 76 - Fator de freio no eixo dianteiro, para a velocidade inicial de frenagem de $80 \mathrm{~km} / \mathrm{h}$

Figura 77 - Força de frenagem no eixo traseiro, considerando diferentes fatores de freio para a velocidade inicial de frenagem de $80 \mathrm{~km} / \mathrm{h}$.

Figura 78 - Escorregamento parcial do eixo traseiro, considerando diferentes fatores de freio para a velocidade inicial de frenagem de $80 \mathrm{~km} / \mathrm{h}$. 
Figura 79 - Coeficiente de aderência no eixo traseiro, considerando diferentes fatores de freio para a velocidade inicial de frenagem de $80 \mathrm{~km} / \mathrm{h}$.

Figura 80 - Fator de freio no eixo dianteiro, para a velocidade inicial de frenagem de $100 \mathrm{~km} / \mathrm{h}$.

Figura 81 - Fator de freio no eixo traseiro, para a velocidade inicial de frenagem de $100 \mathrm{~km} / \mathrm{h}$. 120

Figura 82 - Força de frenagem no eixo dianteiro, considerando diferentes fatores de freio para a velocidade inicial de frenagem de $100 \mathrm{~km} / \mathrm{h}$.

Figura 83 - Força de frenagem no eixo traseiro, considerando diferentes fatores de freio para a velocidade inicial de frenagem de $100 \mathrm{~km} / \mathrm{h}$.

Figura 84 - Escorregamento parcial do eixo traseiro, considerando diferentes fatores de freio para a velocidade inicial de frenagem de $100 \mathrm{~km} / \mathrm{h}$.

Figura 85 - Coeficiente de aderência no eixo traseiro, considerando diferentes fatores de freio para a velocidade inicial de frenagem de $100 \mathrm{~km} / \mathrm{h}$.

Figura 86 - Temperatura no disco de freio dianteiro, com fator de freio variável, considerando diferentes condições de ventilação e velocidade inicial de frenagem de $60 \mathrm{~km} / \mathrm{h}$.

Figura 87 - Temperatura no disco de freio traseiro, com fator de freio variável, considerando diferentes condições de ventilação e velocidade inicial de frenagem de $60 \mathrm{~km} / \mathrm{h}$.

Figura 88 - Variação do fator de freio no eixo dianteiro, considerando diferentes condições de ventilação e velocidade inicial de frenagem de $60 \mathrm{~km} / \mathrm{h}$

Figura 89 - Variação do fator de freio no eixo traseiro, considerando diferentes condições de ventilação e velocidade inicial de frenagem de $60 \mathrm{~km} / \mathrm{h}$.

Figura 90 - Variação do fator de freio no eixo dianteiro, considerando diferentes condições de ventilação e velocidade inicial de frenagem de $80 \mathrm{~km} / \mathrm{h}$.

Figura 91 - Variação do fator de freio no eixo traseiro, considerando diferentes condições de ventilação e velocidade inicial de frenagem de $80 \mathrm{~km} / \mathrm{h}$.

Figura 92 - Força de frenagem no eixo dianteiro, com fator de freio variável, considerando diferentes condições de ventilação e velocidade inicial de frenagem de $80 \mathrm{~km} / \mathrm{h}$. 
Figura 93 - Força de frenagem no eixo traseiro, com fator de freio variável, considerando diferentes condições de ventilação e velocidade inicial de frenagem de $80 \mathrm{~km} / \mathrm{h}$.

Figura 94 - Escorregamento parcial do eixo traseiro, com fator de freio variável, considerando diferentes condições de ventilação e velocidade inicial de frenagem de $80 \mathrm{~km} / \mathrm{h}$.

Figura 95 - Temperatura no disco de freio dianteiro, com fator de freio variável, considerando diferentes condições de ventilação e velocidade inicial de frenagem de $100 \mathrm{~km} / \mathrm{h}$.

Figura 96 - Temperatura no disco de freio traseiro, com fator de freio variável, considerando diferentes condições de ventilação e velocidade inicial de frenagem de $100 \mathrm{~km} / \mathrm{h}$.

Figura 97 - Variação do fator de freio no eixo dianteiro, considerando diferentes condições de ventilação e velocidade inicial de frenagem de $100 \mathrm{~km} / \mathrm{h}$.....

Figura 98 - Variação do fator de freio no eixo traseiro, considerando diferentes condições de ventilação e velocidade inicial de frenagem de $100 \mathrm{~km} / \mathrm{h}$.

Figura 99 - Força de frenagem no eixo dianteiro, com fator de freio variável, considerando diferentes condições de ventilação e velocidade inicial de frenagem de $100 \mathrm{~km} / \mathrm{h}$.

Figura 100 - Força de frenagem no eixo traseiro, com fator de freio variável, considerando diferentes condições de ventilação e velocidade inicial de frenagem de $100 \mathrm{~km} / \mathrm{h}$.

Figura 101 - Escorregamento relativo no eixo traseiro, com fator de freio variável, considerando diferentes condições de ventilação e velocidade inicial de frenagem de $100 \mathrm{~km} / \mathrm{h}$

Figura 102 - Coeficiente de aderência do eixo traseiro, com fator de freio variável, considerando diferentes condições de ventilação e velocidade inicial de frenagem de $100 \mathrm{~km} / \mathrm{h}$.

Figura 103 - Temperatura no disco de freio dianteiro, com fator de freio variável, considerando a instalação do espelho e velocidade inicial de frenagem de $60 \mathrm{~km} / \mathrm{h}$. 
Figura 104 - Temperatura no disco de freio traseiro, com fator de freio variável, considerando a instalação do espelho e velocidade inicial de frenagem de $60 \mathrm{~km} / \mathrm{h}$.

Figura 105 - Fator de freio no eixo dianteiro, considerando a instalação do espelho e velocidade inicial de frenagem de $60 \mathrm{~km} / \mathrm{h}$.

Figura 106 - Fator de freio no eixo traseiro, considerando a instalação do espelho e velocidade inicial de frenagem de $60 \mathrm{~km} / \mathrm{h}$.

Figura 107 - Temperatura no disco de freio dianteiro, com fator de freio variável, considerando a instalação do espelho e velocidade inicial de frenagem de $80 \mathrm{~km} / \mathrm{h}$.

Figura 108 - Fator de freio no eixo dianteiro, considerando a instalação do espelho e velocidade inicial de frenagem de $80 \mathrm{~km} / \mathrm{h}$. 136

Figura 109 - Força de frenagem no eixo dianteiro, com fator de freio variável, considerando a instalação do espelho e velocidade inicial de frenagem de $80 \mathrm{~km} / \mathrm{h}$.

Figura 110 - Temperatura no disco de freio dianteiro, com fator de freio variável, considerando a instalação do espelho e velocidade inicial de frenagem de $100 \mathrm{~km} / \mathrm{h}$.

Figura 111 - Fator de freio no eixo dianteiro, considerando a instalação do espelho e velocidade inicial de frenagem de $100 \mathrm{~km} / \mathrm{h}$.

Figura 112 - Força de frenagem no eixo dianteiro, com fator de freio variável, considerando a instalação do espelho e velocidade inicial de frenagem de $100 \mathrm{~km} / \mathrm{h}$. 


\section{LISTA DE TABELAS}

Tabela 1 - Exigências para aplicações de fricção - SAUER \& FLIEDNER (2001) .25

Tabela 2 - Variação da quantidade de calor dissipado variando com a velocidade e com o tipo de freio a disco - INGRAM (1983). 54 


\title{
LISTA DE ABREVIATURAS E SIGLAS
}

\author{
ABS - Antilock Braking System \\ EBS - Eletronic Braking System
}

ABNT - Associação Brasileira de Normas Técnicas

CONTRAN - Conselho Nacional de Trânsito 


\section{LISTA DE SÍMBOLOS}

$\mathrm{a}=$ aceleração, $\mathrm{m} / \mathrm{s}^{2}$

$\mathrm{A}_{\mathrm{d}}=$ área total do disco de freio, $\mathrm{m}^{2}$

$\mathrm{A}_{\mathrm{l}}=$ área lateral do disco, $\mathrm{m}^{2}$

$\mathrm{A}_{\mathrm{P}}=$ área da pastilha, $\mathrm{m}^{2}$

$\mathrm{A}_{\mathrm{r}}=$ área da roda, $\mathrm{m}^{2}$

$\mathrm{b}=$ coeficiente de resfriamento

ca $=$ calor específico do ar, N.m/kg.K

$\mathrm{Cd}=$ coeficiente de dissipação de calor

$\mathrm{cr}=$ calor específico do disco, N.m/kg.K

Cs $=$ coeficiente de calor armazenado

$\mathrm{C}^{*}=$ fator de freio

dh = diâmetro hidráulico, $\mathrm{m}$

$\mathrm{D}$ = diâmetro externo do disco, $\mathrm{m}$

$\mathrm{E}=$ energia cinética, $\mathrm{J}$

$\mathrm{Ff}_{(\mathrm{d} / \mathrm{r})}=$ fator de forma geométrico entre o disco e a roda

$\mathrm{Ff}_{(\mathrm{d} / \mathrm{a})}=$ fator de forma geométrico entre o disco e o ambiente

$\mathrm{Ff}_{\mathrm{r}}=$ fator de forma da roda para o disco

$\mathrm{Ff}_{\mathrm{d}}=$ fator de forma do disco para a roda

$\mathrm{h}=$ coeficiente de transferência de calor, $\mathrm{W} / \mathrm{m} .{ }^{\circ} \mathrm{C}$

$\mathrm{hr}=$ coeficiente de transferência de calor, $\mathrm{Nm} / \mathrm{hKm}^{2}$

$\mathrm{k}_{\mathrm{a}}=$ condutividade térmica do $\mathrm{ar}, \mathrm{Nm} / \mathrm{hKm}$

$\mathrm{k}_{\mathrm{d}}=$ condutividade térmica do disco, $\mathrm{W} / \mathrm{m} .{ }^{\circ} \mathrm{C}$

$\mathrm{L}=$ comprimento da ventoinha do resfriamento, $\mathrm{m}$

$\mathrm{L}_{\mathrm{dc}}=$ distância do disco ao cubo de roda [m]

$\mathrm{m}$ = massa do veículo, $\mathrm{kg}$

$\mathrm{N}$ = força normal, $\mathrm{N}$

na $=$ número de aplicações do freio

$\mathrm{p}=$ pressão, bar 
$\operatorname{Pr}=$ número de Prandtl = 3600.ca. $\mu \mathrm{a} / \mathrm{ka}$

$\mathrm{q}=$ calor inicial para o tempo $\mathrm{t}^{\prime}=0$

qi $\left(\mathrm{t}^{\prime}\right)=$ calor no tempo $\mathrm{t}^{\prime}$

qo = potência de frenagem absorvida pelo disco, N.m/h

Qc = calor dissipado por condução, $\mathrm{W}$

$\mathrm{Qcv}=$ calor dissipado por convecção, $\mathrm{W}$

$\mathrm{Qr}=$ calor dissipado por radiação, $\mathrm{W}$

Qr(ambiente) = calor dissipado por radiação do disco para o ambiente, $\mathrm{W}$

Qr(roda) = calor dissipado por radiação do disco para a roda, $\mathrm{W}$

$\mathrm{R}=$ força tangencial, $\mathrm{N}$

$\mathrm{Re}=$ número de Reynolds $=[\rho \mathrm{a} \cdot \mathrm{dh} / \mu \mathrm{a}] . \mathrm{Vm}$

$\mathrm{t}$ = tempo durante o qual os freios são aplicados, $\mathrm{h}$

ts $=$ tempo de frenagem para uma parada, $\mathrm{s}$

$\mathrm{Ti}$ = temperatura inicial, $\mathrm{K}$

$\mathrm{Tr}=$ temperatura da face do disco, $\mathrm{K}$

$\mathrm{T}_{\mathrm{d}}=$ temperatura do disco, ${ }^{\circ} \mathrm{C}$

$\mathrm{T}_{\mathrm{a}}=$ temperatura ambiente, ${ }^{\circ} \mathrm{C}$

$\mathrm{T}_{\mathrm{C}}=$ temperatura do cubo de roda, ${ }^{\circ} \mathrm{C}$

$\mathrm{T}_{\mathrm{r}}=$ temperatura da roda, ${ }^{\circ} \mathrm{C}$

$\mathrm{T}_{\mathrm{s}}=$ temperatura de estabilização, ${ }^{\circ} \mathrm{C}$

$\mathrm{v}=$ velocidade do veículo, $\mathrm{m} / \mathrm{s}$

$\mathrm{vr}=$ volume do disco, $\mathrm{m}^{3}$

$\mathrm{Vm}$ = velocidade média, $\mathrm{m} / \mathrm{s}$

$\mu=$ coeficiente de fricção entre o disco e a pastilha

$\mu \mathrm{a}=$ viscosidade do ar, $\mathrm{kg} / \mathrm{m} . \mathrm{s}$

$\gamma \mathrm{b}=$ efeito das partes rotativas

$\sigma=$ constante de Stefan-Boltzman $=5,669 \cdot 10^{8} \mathrm{~W} / \mathrm{m}^{2} \cdot \mathrm{K}^{4}$

$\varepsilon=$ emissividade

$\varepsilon \mathrm{r}=$ emissividade do disco

$\rho=$ densidade do material, $\mathrm{kg} / \mathrm{m}^{3}$

$\rho \mathrm{a}=$ densidade do $\mathrm{ar}, \mathrm{kg} / \mathrm{m}^{3}$

$\rho r=$ densidade do disco, $\mathrm{kg} / \mathrm{m}^{3}$ 


\section{RESUMO}

IOMBRILLER, S. F. (2002). Análise térmica e dinâmica do sistema de freio a disco de veículos comerciais pesados. São Carlos, 2002. 177p. Tese (Doutorado) Escola de Engenharia de São Carlos, Universidade de São Paulo.

Este trabalho desenvolve um procedimento para a análise dinâmica da frenagem total de emergência de um veículo de dois eixos (4x2), considerando os efeitos do aumento da temperatura no sistema de freios.

Um protótipo de ônibus urbano equipado com freios a disco foi utilizado nos ensaios em perímetro urbano e em pista de teste da TRW Automotive em Limeira SP. O sistema de freios do veículo protótipo foi instrumentado com termopares em diversos de seus componentes, com sensores de velocidade e pressão, percorrendo um perímetro típico urbano com trânsito intenso na cidade de São Paulo. Os pontos críticos de aquecimento foram observados bem como sua tendência de aumento de temperatura no tempo.

Paralelamente ao teste em perímetro urbano foi realizado um teste padrão de fade na pista da TRW Automotive, estendendo o ciclo de frenagens até se observar o aumento e estabilização da temperatura do sistema de freios.

Simultaneamente aos testes de pista foi realizado um teste em dinamômetro inercial na Fras-Le, em Caxias do Sul - RS, para se obter a variação do fator de freio com a variação da temperatura do sistema de freios.

Parte de um programa computacional em Matlab foi desenvolvido que simula computacionalmente o veículo freando, considerando os efeitos da temperatura do sistema de freios, durante frenagens totais de emergência, partindo de diferentes velocidades iniciais de frenagem. O sistema de freios em estudo mostrou-se capaz na simulação de frear o veículo em emergência mesmo estando em altas temperaturas observadas no perímetro urbano.

Palavras-chave: freios a disco, análise térmica, análise dinâmica de veículos. 


\section{ABSTRACT}

IOMBRILLER, S. F. (2002). Thermal and dynamic analysis of disc brake system of heavy vehicles. São Carlos, 2002. 177p. Tese (Doutorado) - Escola de Engenharia de São Carlos, Universidade de São Paulo.

One procedure for vehicle dynamics analysis during total emergency braking in a two axles vehicle $(4 \times 2)$ was developed. For this procedure the effect of increasing temperature in the brake system was considered.

A bus (prototype) equipped with disc brake was used in two practical test when the bus go through: a urban rout (São Paulo city) and a TRW's test lane (Limeira - SP).

Thermocouples were installed in several parts of the brake system as well as velocity and pressure sensors. Acquisitions of date were made during the intensive traffic of São Paulo city. Critical temperature points were observed as well as the raise temperature tendency with the time.

Tests in an inertial dynamometer were also performed in Fras-Le company (Caxias do Sul - RS) to get the brake factor variation related to temperature variation of the brake system.

Simulation using MatLab program to study the vehicle performance during braking was developed. In this simulation the effect of brake system temperature was considered. Two main conclusions could be obtained: MatLab model is a useful tool to study emergency braking considering the variation of brake system and the brake system studied was able to stop the vehicle in a emergency braking even under high temperature.

Keywords: disc brakes, thermal analysis, vehicle dynamic analysis. 


\section{INTRODUÇÃO}

Muitas têm sido as mudanças adotadas nos autoveículos na última década, melhorando a potência dos motores, reduzindo o arrasto aerodinâmico e a resistência ao rolamento dos pneus, tornando o consumo de combustível mais eficiente e otimizando a capacidade de carga. E, embora a velocidade média tenha aumentado, através de dispositivos de segurança, é possível se observar maior conforto e estabilidade mesmo em alta velocidade.

ROMARO (1998) salienta que a busca por um equilíbrio que favoreça o convívio entre homem, veículo, via e meio-ambiente, de uma maneira adequada e disciplinada é cada vez mais importante. Visando uma interface satisfatória entre tais fatores, sugere ainda que o aumento da segurança veicular e conseqüentemente a redução no número de acidentes de trânsito, baseia-se principalmente:

- na mudança do comportamento do motorista;

- nos projetos mais modernos e seguros das vias;

- na melhoria do desempenho da segurança ativa e passiva dos veículos.

Recentemente as técnicas de desenvolvimento de veículos pesados têm avançado rapidamente. Em especial na Europa, os sistemas de freios, a fixação dos freios e as suspensões têm mudado muito e BOIOCCHI (1999) destaca que soluções como freios a disco, sistemas de freios com ABS (Antilock Braking System) e EBS (Eletronic Braking System) e suspensões a ar tornaram-se equipamentos padrão em muitos caminhões. No entanto, no Brasil, o desenvolvimento de veículos pesados segue o caminho europeu, com alguns anos de atraso e com adaptações obviamente necessárias para as diferentes condições operacionais.

Para que um veículo seja desenvolvido de maneira eficiente é necessário que o desempenho de cada componente seja estimado acuradamente durante a fase de projeto. 
Muitas são as partes que contribuem ativa ou passivamente para que um veículo ofereça um desempenho satisfatório, mas sua segurança está intimamente ligada à eficiência do sistema de freios, o qual está sujeito a elevadas cargas mecânicas e térmicas.

Assim, torna-se de fundamental importância a acuracidade na análise e desenvolvimento do sistema de freios, considerando todos os aspectos envolvidos em seu comportamento térmico e dinâmico.

A fim de melhorar o desempenho do sistema de freios, bem como do veículo, sem inviabilizá-lo economicamente, atendendo às necessidades do mercado consumidor é preciso buscar:

- otimizar mão-de-obra

treinando e qualificando os profissionais;

- reduzir custos

considerando cuidadosamente a relação custo/benefício nas possíveis modificações;

- aperfeiçoar o projeto e a produção

avaliando novos materiais, bem como novos métodos de produção;

- reduzir o tempo de desenvolvimento

tornando os cálculos e ensaios mais objetivos;

- diversificar os produtos

oferecendo uma gama maior de alternativas ao consumidor, de acordo com diversas necessidades.

Segundo KOWALSKI \& EBERT (1993), os engenheiros projetistas não podem mais limitar suas avaliações aos parâmetros físicos tradicionais, como distância de frenagem, torque e balanceamento de frenagem, pois mesmo sendo considerações fundamentais, podem não relacionar diretamente desempenho na frenagem à percepção do motorista.

Historicamente, a sensação do veículo freando tem sido usualmente avaliada de uma maneira subjetiva. As medidas usadas mais objetivas foram a relação entre a desaceleração do veículo e a distância de frenagem. 
No entanto, a distância de frenagem representa o desempenho do limite da frenagem, mas ignora o desempenho sob condições normais de uso, o que é experimentado na maior parte do tempo.

EBERT \& KAATZ (1994) tem desenvolvido um método para traduzir as expectativas de sensibilidade do freio do ponto de vista do consumidor (usuário) para o desempenho métrico objetivo. Essas medidas são correlacionadas com avaliações subjetivas atuais e são usadas para fixar objetivos nos requisitos mensuráveis de desempenho. Tendo definido tais requisitos, pode-se usar um modelo computacional para tornar o projeto e processo mais rápido no desenvolvimento de um veículo, o qual terá uma grande conformidade com a satisfação do consumidor.

O sistema de freios de um veículo tem por finalidade proporcionar ao motorista uma ação segura de desaceleração levando à redução da velocidade do veículo, conforme as condições de tráfego e o desejo do motorista, obedecendo aos requisitos estabelecidos pelo fabricante do veículo e pela legislação vigente, como destaca FERNANDES (2000).

No entanto, deve-se ter sempre em vista as exigências essenciais para um sistema de freios; tais como:

- alta eficiência;

- pequena histerese;

- alto fator de freio;

- redução do fade;

- boas características de resposta;

- grande vida útil do material de fricção;

- redução de peso;

- facilidade de manutenção;

Em um projeto otimizado de freio a disco, o espaço disponível e o peso máximo permitido também irão limitar as dimensões e a energia térmica do freio, como destaca DIKE (1974).

Durante muito tempo o projeto de freios foi dependente unicamente da experiência, resolvendo seus problemas através de protótipos pelo método de 
tentativa e erro, o que requer muito tempo para o desenvolvimento e conseqüentemente muitos recursos financeiros.

Para diminuir estes tempos as empresas vêm utilizando tecnologias computacionais de cálculo e simulação, reduzindo os ensaios a um mínimo suficiente para o desenvolvimento do projeto.

Através de métodos de cálculo como o método de elementos finitos, já é possível prever e simular o comportamento do sistema de freios em relação às características de rigidez e vibração, com certa facilidade. Entretanto, para desenvolver e aplicar um método de análise de seu comportamento térmico são ainda necessários alguns dados empíricos, em virtude da dificuldade em se quantificar os coeficientes de transferência de calor, por dependerem estes de condições bastante específicas e particulares.

No entanto, torna-se cada vez mais necessário prever teoricamente o desempenho do sistema de freios, considerando os aspectos térmicos, buscando diminuir custos através da redução dos testes de pista, e aumentar a segurança veicular através de uma maior eficiência de frenagem.

Com a finalidade de avaliar de forma objetiva o desempenho dinâmico do sistema de freios, foi elaborado um método de simulação veicular considerando a influência térmica durante a frenagem.

Considerando o levantamento bibliográfico realizado sobre o assunto, tal análise mostra-se original e inovadora, conciliando a abordagem dinâmica e térmica do sistema de freios na simulação veicular.

Assim, o principal objetivo deste trabalho é o desenvolvimento de um procedimento prático, com embasamento matemático e com utilização de recursos computacionais, de aplicação industrial, que permita prever o desempenho de um veículo em frenagens de emergência, sob condições de contorno obtidas em tráfego urbano, consideradas estas como condições operacionais severas. Tanto o procedimento prático como o modelo matemático, devem considerar os efeitos térmicos no desempenho do sistema de freios.

Para o desenvolvimento do procedimento prático, do modelo matemático e do programa computacional será utilizado um ônibus protótipo, de uso urbano, equipado com freios a disco. Os testes práticos serão desenvolvidos em perímetro urbano 
típico da Grande São Paulo e arredores, sob severas condições operacionais, e na pista de testes da TRW Automotive , em Limeira - SP, sob condições normalizadas, além de testes em dinamômetro inercial nos laboratórios da Fras-Le, em Caxias do Sul - RS.

Como objetivos complementares, foi ainda possível obter dos testes em perímetro urbano, bem como da análise termográfica em dinamômetro, um mapeamento térmico do disco de freio, indicando pontos críticos para a instrumentação.

O programa computacional desenvolvido para simulação, considera o veículo freando em emergência, partindo de condições iniciais encontradas nos testes em perímetro urbano, sob severas condições operacionais.

Com a finalidade de oferecer uma visão geral da organização deste trabalho, segue abaixo uma descrição sucinta dos capítulos que o compõem.

No Capítulo 2 encontra-se uma breve descrição da problemática do aquecimento do sistema de freios.

No Capítulo 3 tem-se uma revisão bibliográfica abordando a aplicação de freios a disco e os diferentes materiais utilizados tanto nos discos como nos materiais de fricção. Encontram-se relacionados ainda, os trabalhos desenvolvidos em diferentes tipos de modelagens térmicas do sistema de freios.

No Capítulo 4 tem-se uma descrição da metodologia aplicada ao sistema de freios como um sistema térmico cujo desempenho é fortemente influenciado pela geração de calor, transferências de calor por condução, convecção e radiação, pelas características físicas e construtivas dos sistemas e pela forma de operação do equipamento. Os critérios de cálculo adotados e o programa computacional também se encontram descritos neste capítulo.

O Capítulo 5 mostra a instrumentação do sistema de freios, utilizada para a realização dos ensaios em perímetro urbano, em pista de testes e em dinamômetro inercial, bem como os resultados obtidos nestes ensaios. Tais resultados nortearam o desenvolvimento do procedimento prático, do modelo matemático e do programa computacional desenvolvido. 
No Capítulo 6 é realizada uma aplicação da simulação computacional desenvolvida, considerando o veículo protótipo freando em emergência após atingir as temperaturas de estabilização nos discos de freio.

O Capítulo 7 contém as principais conclusões obtidas no desenvolvimento deste trabalho e no Capítulo 8 são ainda sugeridas outras propostas de trabalhos futuros considerando os aspectos térmicos na simulação veicular. 


\section{ASPECTOS DA UTILIZAÇÃO DO SISTEMA DE FREIOS}

Algumas condições de utilização do veículo podem agravar significativamente o efeito térmico no sistema de freios, aumentando a temperatura do disco, bem como de rodas e pneus.

Entre as principais situações críticas a que os veículos são solicitados pode-se citar:

- pistas irregulares;

- congestionamento;

- sobrecarga;

- direção agressiva

- excesso de velocidade;

- manobras bruscas;

- ausência do uso de mecanismos atenuadores, tais como:

- freio motor;

- freio auxiliar retardador;

Além desses fatores, a melhoria no desenvolvimento dos motores, aumentando sua potência conseqüentemente aumenta a velocidade média com que trafegam os veículos.

Uma das mais comuns justificativas para acidentes de trânsito, especialmente envolvendo veículos comerciais pesados, é a chamada "falta" de freio. No entanto, ROMARO (1998) faz algumas considerações:

- todos os veículos, independentes de tipo, classe ou marca, são projetados segundo rígidas normas internacionais; 
- no caso dos freios, eles são desenvolvidos conforme a norma européia ECER13, cujo espaço de frenagem do veículo é especificado e limitado para diferentes condições de carga e velocidade;

- todos os componentes do veículo são exaustivamente testados em durabilidade.

No entanto, a frenagem exige um determinado espaço até a imobilização total do veículo, espaço este diretamente ligado ao tempo de reação do motorista, à velocidade, carga e manutenção do veículo, além das condições de atrito da pista.

Desta forma, torna-se possível concluir que as falhas atribuídas ao sistema de freios, em sua grande maioria, correspondem à condições de utilização do veículo diferentes das especificadas, além da ausência de manutenção correta do sistema de freios.

No caso do tráfego urbano, principalmente nos grandes centros, ocorrem freqüentes paradas com alta desaceleração e curto espaço de tempo para resfriamento, devido à grande incidência de lombadas, valetas, semáforos, além das paradas obrigatórias e dos congestionamentos.

Como este tráfego ocorre em baixas velocidades, isto reduz ainda mais as possibilidades de resfriamento pelo fluxo de ar que atravessa o sistema de freios.

O percurso típico dos ônibus urbanos é descrito por PAULETTI (1993) como caracterizado por ciclos de aceleração e desaceleração de curto período. Em cada um desses ciclos, o veículo passa do repouso para a velocidade de passeio, trafegando nesta velocidade por um determinado intervalo de tempo e a seguir sofre um processo de frenagem. Desta forma a energia cinética do veículo é dissipada sob forma de calor, provocando o aumento da temperatura no sistema de freios.

Além de todos os fatores já citados, o comportamento do motorista tem um importante papel no processo de frenagem, o que tem sido alvo de estudo por diversos pesquisadores, entre os quais destacam-se LISTER (1950), TEICHNER (1954), LERNER (1993), SCHWEITZER; APTER; PARUSH; LIEBERMANN \& BEM-DAVID (1995), SOHN \& STEPLEMAN (1998).

Tratando-se dos grandes centros, em virtude do tráfego denso e constantemente congestionado, os motoristas encontram-se freqüentemente sob 
condições de desgaste emocional, apresentando um comportamento mais agressivo ao volante, o que causa frenagens mais bruscas e uma utilização menos cuidadosa do veículo e conseqüentemente do sistema de freios.

Se a estas condições críticas somar-se ainda que muitos veículos trafegam com sobrecarga e com o veículo sem manutenção, tendo além de discos e pastilhas desgastados (o que provoca redução da eficiência de frenagem, já que compromete o contato disco/pastilha), também pneus desgastados (o que reduz sensivelmente o atrito com o solo durante a frenagem), inevitavelmente o sistema de freios sofrerá superaquecimento.

\subsection{PROBLEMAS TÉRMICOS}

O superaquecimento do disco de freio pode trazer sérias conseqüências, reduzindo a segurança veicular.

Os principais problemas associados ao aquecimento do par de fricção são:

- Fade - Trata-se da perda de atrito entre disco e pastilha, provocada pelo excessivo calor gerado durante as frenagens. Segundo LIMPERT (1992), nos freios a disco só aparece significativamente acima de $400^{\circ} \mathrm{C}$. No entanto, esta perda de atrito deve manter-se dentro de limites aceitáveis, de modo que o sistema de freio ainda apresente uma boa eficiência na frenagem.

- Distorções cônicas - Também são responsáveis pela redução do contato entre disco e pastilha, principalmente sob condições de tráfego urbano, modificando as condições de contato entre o disco e a pastilha, podendo gerar instabilidade na frenagem.

Tal distorção do disco foi modelada por DAY, TIROVIC \& NEWCOMB (1991) em um modelo tridimensional da parte interna em contato com a pastilha, concluindo que a diminuição da atuação das forças na face interna em contato com a pastilha mostrou ter mais influência da distorção cônica do disco do que da distribuição de pressões. 
YEVTUSHENKO \& YVANYK (1995) também avaliaram os efeitos do calor na distorção da interface do disco na região de contato friccional. Destacaram os autores que embora possa considerar-se em determinados cálculos a região de contato sendo constante durante o processo de fricção, bem como as propriedades térmicas dos materiais, sabe-se que o aquecimento friccional da superfície leva à distorção térmica, a qual sofre variação no tempo, como pode ser observado na Figura 1.

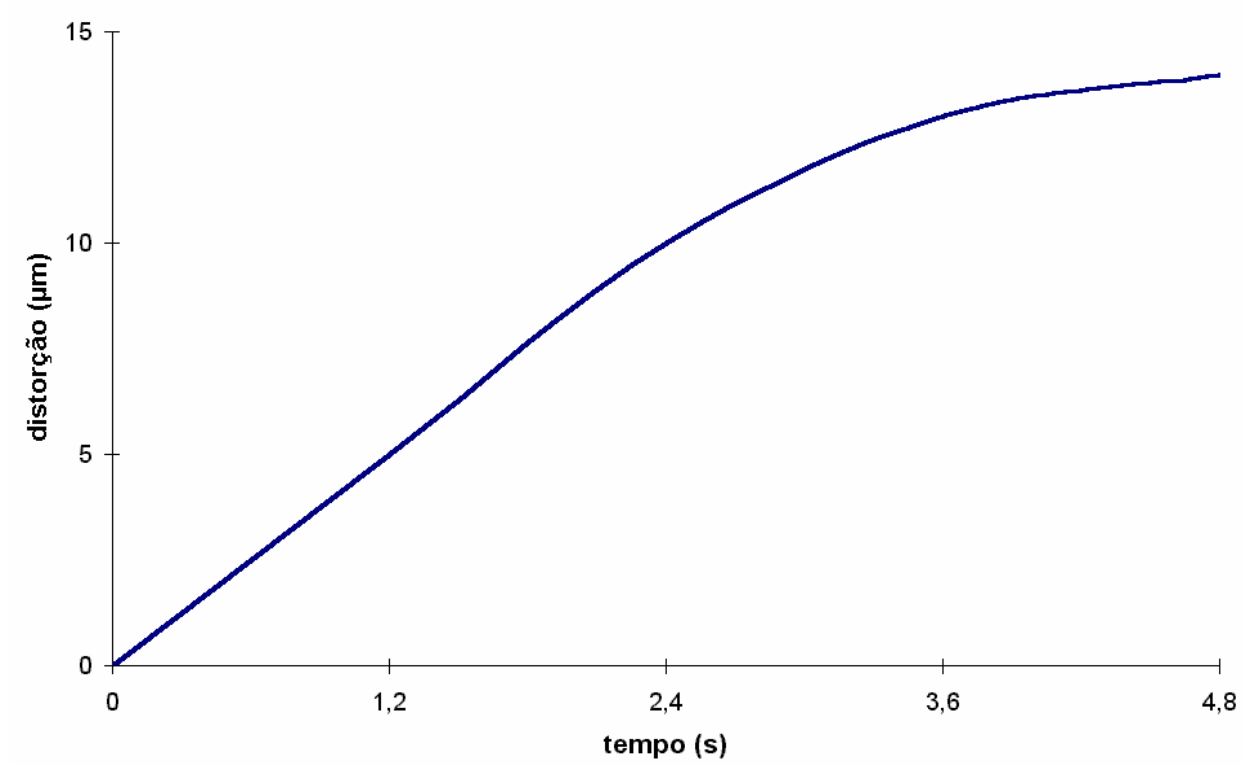

Figura 1 - Mudança na distorção térmica em relação ao tempo - YEVTUSHENKO \& YVANYK (1995)

- Mudança do coeficiente de friç̧ão - O coeficiente de friç̧ão é característica particular da pastilha utilizada, entretanto, quando o limite térmico do material é ultrapassado, aumenta o desgaste e seu comportamento muda, reduzindo seu coeficiente de friç̧ão e conseqüentemente a eficiência de frenagem.

- Variação do fator de freio - O fator de freio é definido por GILLESPIE (1992) como a razão entre a força de frenagem produzida no contato disco/pastilha e a força aplicada para comprimir as pastilhas contra o disco. Algumas variáveis podem influenciar o fator de freio, tais como a temperatura, a pressão e a velocidade na frenagem. Entretanto, como observado por IOMBRILLER (1997), a temperatura é a variável mais significativa, em muitos veículos, reduzindo o fator de freio. A 
redução do fator de freio será diretamente responsável pela redução das forças de frenagem, tornando o sistema de freios menos eficiente.

- Pontos de aquecimento no disco - As altas temperaturas locais no disco provocam pontos de aquecimento, ocasionando mudança do comportamento do metal. Tais pontos são partes do metal que apresentam descoloração devido à geração de calor por altas taxas de fricção. Uma característica destes pontos é que se apresentam mais duros que o resto da superfície devido às transformações metalúrgicas e à formação da martensita. Além disso, costumam apresentar-se regularmente espaçados ao redor do disco.

- Trincas no disco - Além dos pontos de aquecimento também podem surgir manchas de aquecimento devido a grandes taxas de trabalho aplicadas ao disco e à pressão não uniforme no contato disco/pastilha, como destacam DAY, TIROVIC \& NEWCOMB (1991). Foi possível observarem ainda que a distribuição de pressão foi muito ruim para operações leves quando o disco estava cônico e o contato cobriu somente $60 \%$ da superfície de fricção (pastilha), comparando com $80 \%$ no estado normal.

Tais pontos e manchas de calor causam trincas no disco em virtude do escoamento plástico do material da superfície, induzindo tensões após o resfriamento.

O contínuo uso pesado do veículo associado a tensões cíclicas poderá causar fadiga, propagando as trincas e provocando a quebra do disco.

FUAD, DAIMARUYA \& KOBAYASHI (1994) analisaram o mecanismo inicial da quebra térmica em tambor de freio, investigando as distribuições de temperatura e das tensões térmicas no tambor de freio durante o seu aquecimento e resfriamento, através de um modelo bidimensional axisimétrico pelo método de elementos finitos. Observaram que efeitos indesejáveis causados pelos aumentos de temperatura e tensões térmicas que conduzem ao início de uma trinca e conseqüente a quebra, podem ser pequenos para um veículo de passeio, mas são preocupantes para veículos comerciais pesados.

Uma investigação teórica e experimental sobre trincas e quebras em discos de freio para caminhões com peso total superior a 7,5 toneladas foi realizada por KLOOS (1999). Algumas de suas principais conclusões foram: 
1. Trincas em discos são vistas mais freqüentemente em caminhões que percorrem longa distância;

2. Quanto maior o disco, maior o problema de trincas. Para um disco de 17,5 polegadas é menos provável de ocorrer falha do que para um disco de 22,5 polegadas;

3. Discos combinados com pastilhas de alto nível de fricção são mais prováveis de apresentar falhas;

4. As trincas no disco podem ser influenciadas pelo caliper, pela deflexão axial da pastilha e pelo material do próprio disco, quando a frenagem ocorre com altas forças de entrada;

5. Em frenagem contínua, as trincas podem ser influenciadas pela pastilha (desgaste, deflexão axial e expansão) e pelo disco (material e forma).

- Desgaste - Quando altas temperaturas são atingidas no sistema de freios alterando a forma de contato disco/pastilha, o desgaste do material de friç̧ão não será uniforme. Assim, a vida útil das pastilhas será reduzida, e caso não seja feita sua troca, o freio ficará cada vez mais sensível e irregular.

No entanto, o desgaste das pastilhas de freio varia de acordo com o freio usado, como destacam MINEGISHI, SHIMIZU, WAKAMATSU \& YOSHINO (1984).

Os desgastes mais comuns que ocorrem nas pastilhas em freios a disco de veículos comerciais são:

$\Rightarrow$ tangencial;

$\Rightarrow$ radial;

$\Rightarrow$ côncavo.

Estes tipos de desgaste também podem ser ocasionados por:

- forças de atuação consideravelmente altas;

- variação da distribuição de pressões sobre a superfície da pastilha;

- tensões da estrutura do caliper.

As pastilhas de freio que apresentam algum destes tipos de desgaste irregular têm como conseqüência os choques no cilindro de freio e uma queda na eficiência como resultado da redução do raio efetivo de frenagem. Além disso, poderá ocorrer um aumento no curso do pistão, resultando em um consumo alto de ar. 
O desgaste côncavo é particularmente crítico, já que as pastilhas estão sujeitas a altas cargas mecânicas e visto que pode provocar a quebra das sapatas como resultado de sua deflexão e com o decorrer do tempo pode ocasionar trincas, e gradualmente conduz para frenagens com falta de contato da maior parte das pastilhas. Como conseqüência, a vida útil das pastilhas deve divergir consideravelmente daquela determinada teoricamente.

GUDMAND-HAYER, BACH, NIELSEN \& MORGEN (1999) estudaram as propriedades tribológicas de freios a disco automotivos com diferentes pastilhas e concluíram que a variação na fricção e no desgaste é muito maior quando a frenagem ocorre em altas temperaturas e pressão do que para baixas temperaturas e pressão.

Outras partes do sistema de freios também podem ser afetadas pelas grandes taxas de calor atingidas, como eixos, rodas, rolamentos, retentores e pneus. Em alguns destes componentes pode ocorrer alteração em suas propriedades, fazendo com que sua vida útil seja reduzida.

COSTA, IGLESE, NATALINI \& XAVIER (1996) destacam que embora as rodas sejam aquecidas por radiação, estas aquecem os pneus por condução. Quando ocorre superaquecimento, o calor que chega aos pneus provoca um envelhecimento precoce dos compostos de borracha nos talões, com perda das características físicas.

Através de provas severas, reproduziram também as situações extremas de utilização, concluindo que o pneumático fica inalterado até $100^{\circ} \mathrm{C}$. A partir desta temperatura, a vida dos compostos de borracha decresce exponencialmente.

A fim de estudarem a influência dos fatores responsáveis pelo superaquecimento, bem como para avaliarem o efeito de modificações no projeto de veículos, os autores propuseram um modelo em elementos finitos utilizando fórmulas semi-empíricas para obtenção dos coeficientes de transferência de calor. 


\subsection{RUMOS E TENDÊNCIAS}

Nos últimos anos vem se tornando cada vez mais comum a utilização de freios a disco em veículos pesados, substituindo os tambores de freio. Isto se deve principalmente à busca de maior eficiência na frenagem, assim como a menor ocorrência do fenômeno de fade, já que os freios a disco suportam temperaturas superiores às que suportam os freios a tambor.

Entretanto, observa-se que a simples troca do sistema tambor/lona pelo sistema disco/pastilha não é suficiente, tornando-se necessária a análise do sistema de freio como um todo, bem como sua influência no desempenho do veículo e na segurança veicular.

No entanto, o próprio conceito de segurança veicular vem passando por modificações, ultrapassando os limites internos do veículo e destacando também sua iteração com o meio ambiente e a sociedade.

Tais modificações de conceitos vêm sendo refletidas nas alterações da própria legislação para homologação de novos sistemas.

Segundo POVEL, BERGMANN, VON GLASNER \& MARWITZ (2000), para atingir um aumento satisfatório na segurança ativa, os fabricantes de veículos comerciais tem aumentado consideravelmente seus esforços, desenvolvendo sistemas eletrônicos inteligentes para melhorar o desempenho de seus veículos.

DUSI \& ADAS (2001) destacam que para manter o nível de segurança em um veículo onde novas tecnologias são usadas para aumentar a capacidade de carga e a velocidade de operação, novas tecnologias também devem ser usadas nos demais sistemas do veículo, como no sistema de freios.

Alguns dos aspectos que podem tornar a frenagem de veículos comerciais mais segura, são:

- melhorar a atuação e a resposta do pedal de freio;

- aumentar a eficiência de frenagem;

- minimizar a redução no desempenho que ocorre durante o fade. 
GILLESPIE (1992) mostra que há uma relação entre eficiência de frenagem e ocorrência de escorregamento total das rodas durante a frenagem, destacando que quanto maior a eficiência de frenagem menor a probabilidade de ocorrer escorregamento total das rodas.

FERNANDES, CANALE, ADAS \& FONSECA (1995) salientam que a ocorrência de escorregamento total das rodas de qualquer eixo pode afetar a dirigibilidade do veículo, o que pode levar à ocorrência de acidentes. Concluem desta forma que melhorar a eficiência da frenagem é elevar o desempenho e proporcionar maior estabilidade ao veículo, e que evitar o escorregamento das rodas é reduzir o número de acidentes, o que contribui efetivamente para aumentar a segurança veicular.

CANALE \& RUFFINO (1993) destacam ainda que a prevenção do deslizamento de um autoveículo rodoviário é a chave para se manter a estabilidade direcional e a manobrabilidade numa frenagem.

É preciso que a engenharia automotiva caminhe rumo à segurança veicular, submetendo ao processo de análise e otimização todos os componentes que contribuem ativa ou passivamente para a segurança.

Diversos trabalhos tem sido desenvolvidos avaliando os efeitos do aquecimento do par de fricção de freios a disco, bem como muitas pesquisas foram realizadas para analisar o desempenho dinâmico do veículo na frenagem. No entanto, na elaboração deste trabalho, busca-se avaliar o comportamento dinâmico do veículo durante a frenagem, considerando os efeitos do aquecimento do sistema de freios. Através da metodologia de análise e do programa de cálculo desenvolvidos será possível reduzir o tempo e o custo das modificações no projeto de novos veículos, bem como de melhorias nos modelos já utilizados, a fim de contribuir efetivamente para o aumento da segurança veicular. 


\section{REVISÃO BIBLIOGRÁFICA}

\subsection{FREIOS A DISCO}

INGRAM (1983) relata que já no início dos anos 60 houve veículos com todos os freios a disco, tratavam-se do BMMOS14 (um ônibus simples, urbano) e o CM5 (um ônibus rodoviário), dos quais foram produzidos conjuntamente cerca de 400 unidades. Estes veículos foram equipados com freios hidráulicos a disco nos eixos dianteiro e traseiro, com um balanceamento de frenagem de 50/50 e peso total bruto de 7,9 e 9,7 toneladas, respectivamente.

O sucesso desta inovação tecnológica levou outras fábricas a considerarem o uso do freio a disco no projeto de seus ônibus e caminhões. Em meados dos anos 60, Guy Motors colocou o GVW (um ônibus de dois andares para 14 toneladas), em serviço com freios a disco em ambos os eixos. A despeito do fato de que um grande avanço tecnológico tenha sido encontrado na instalação do freio a disco neste veículo, a vida útil da pastilha no veículo em uso foi inadequada, cerca de 16 a 24 mil km, quando se esperava 120 mil km. Conseqüentemente, o freio a disco nesses veículos foi substituído por freio a tambor.

Nos anos 70 houve um ressurgimento do interesse em freios a disco, mas sendo centrado nos veículos leves (1,8 a 3,5 toneladas).

A partir dos anos 80, os programas de fabricação de veículos foram mais seriamente considerados, resultando em uma adoção de freios a disco em larga escala.

Atualmente mais de 50\% dos veículos produzidos na Europa vêm equipados com freio a disco. 
Os freios a disco, de um modo geral tem apresentado algumas vantagens no desempenho em veículos:

- facilidade de operação devido às menores variações na frenagem com as mudanças de velocidade;

- mantém sua eficiência de frenagem até em altas temperaturas porque a redução da força de frenagem após repetidas aplicações do freio é pequena;

- curva de torque plana, com uma pequena mudança da força de frenagem durante a aplicação dos freios.

O freio a disco construtivamente apresenta um projeto mais compacto, podendo proporcionar uma redução de até $60 \mathrm{~kg}$ em um veículo de dois eixos, como afirmam DUSI \& ADAS (2001).

BOIOCHI (1999) enfatiza ainda outras importantes características do freio a disco:

- maior força de frenagem - esta característica é geralmente usada pelos fabricantes de veículos pesados para aumentar o desempenho do freio e reduzir a distância de frenagem.

- insensibilidade ao coeficiente de friç̧ão da pastilha - o efeito desta característica do freio a disco é bom para a estabilidade do veículo, mantendo constante a força de frenagem.

Entretanto, torna-se necessário que apresente algumas características que definem seu projeto, entre as quais:

* desempenho térmico;

* desempenho mecânico;

* durabilidade;

* acondicionamento;

* massa;

* facilidade construtiva;

* facilidade de manutenção. 
Freios a disco têm uma maior área de superfície exposta à atmosfera que os freios a tambor e conseqüentemente se resfriam com maior eficiência. Entretanto, este maior resfriamento só é observado durante repetidas frenagens, pois NEWCOMB (1960) realizou experimentos que mostraram uma redução térmica muito pequena nas frenagens de emergência, cerca de $6 \%$.

Posteriormente, foi feita por NEWCOMB \& MILLNER (1965) uma avaliação da capacidade de resfriamento, comparando-se freios a tambor e a disco. Através de termopares inseridos nos sistemas de freios, avaliaram seu comportamento após um aquecimento de cerca de 300 a $400{ }^{\circ} \mathrm{C}$, variando a velocidade de frenagem. Entre os resultados obtidos, destaca-se que:

- as razões de resfriamento dos freios dianteiros são cerca de $20 \%$ maiores que os freios traseiros;

- freios a disco dianteiros resfriam-se cerca de $25 \%$ mais rápido que os freios a tambor de tamanho equivalente, recomendado para o mesmo veículo.

De acordo com GOHRING \& VON GLASNER (1988), uma das características significativas dos freios a disco é a facilidade na troca das pastilhas. Estas podem ser removidas em uma direção radial, sem a necessidade de usar-se ferramentas especiais. Já nos freios a tambor, perde-se muito tempo tirando e pondo rebites.

No entanto, destacam ainda que uma desvantagem do freio a disco é o desgaste da pastilha. Dependendo da forma como as forças são aplicadas, desgastes consideráveis no sentido radial, tangencial ou côncavo podem ocorrer quando as pastilhas são deformadas correspondentemente, resultando que:

- o volume da pastilha não pode ser completamente usado;

- o curso do freio torna-se maior e conseqüentemente a distância de frenagem aumenta.

TANAKA, KUBOTA, IWASAKI \& HATANAKA (1990) avaliaram a compatibilidade de freios a disco e a tambor instalados em veículos combinados através de:

- comparação das características dos freios a disco e a tambor usando um dinamômetro; 
- previsão do comportamento dos veículos combinados freando nas curvas pela média da simulação calculada;

- confirmando a compatibilidade nos testes do veículo em pista:

- comparando os testes de eficiência de frenagem e de recuperação do fade;

- comparando o comportamento durante a frenagem em curva.

Como resultado observaram que:

1. Os freios a disco mostram menor variação na força de frenagem com a velocidade, o que é uma excelente característica para freios em geral;

2. Os freios a disco mostram alta elevação da temperatura quando os freios são aplicados repetidamente;

3. Os freios a disco também experimentam uma pequena queda na eficiência de frenagem, ou menores variações na potência de frenagem com a mudança da temperatura;

4. O torque de frenagem nos freios a disco muda menos que nos freios a tambor. Além disso, freios a disco têm uma característica de torque plano;

5. Veículos combinados com freios a disco instalados no cavalo e freios a tambor na carreta são melhores que veículos com freios a tambor unicamente, em desempenho na frenagem, conferindo maior estabilidade ao veículo em altas velocidades e alta resistência ao fade;

6. Já que os freios a disco e a tambor têm diferentes fatores de freio e tem suas forças de frenagem variando diferentemente com a velocidade, torna-se imprescindível o correto balanceamento do veículo, testando-o sob várias condições de fade para diversas velocidades até encontrar-se uma boa distribuição das forças de frenagem.

Geralmente a distribuição do peso próprio de um veículo e de suas cargas não é uniforme entre as rodas de cada eixo, acarretando um trabalho de frenagem diferente para cada freio. A proporção de frenagem normalmente mantém-se constante para cada tipo de veículo, definindo assim seu balanceamento.

A condição de máximo desempenho do sistema de freio de um auto-veículo é conseguida somente quando a distribuição das forças de frenagem nos eixos dianteiro 
e traseiro, tiver a mesma proporção dos respectivos pesos dinâmicos, conforme CANALE \& RUFFINO (1993a).

A distribuição ideal das forças de frenagem nos eixos do veículo ocorre quando as rodas de cada eixo utilizam a máxima fricção longitudinal entre o pneu e a pista durante o processo de frenagem. Nesta condição, as rodas de cada eixo estão no limite do escorregamento.

Por isso, a distribuição da força de frenagem deve seguir a distribuição das forças verticais nos eixos do veículo durante o processo de frenagem.

A distribuição das forças de frenagem indica a participação de cada eixo na força total de frenagem produzida pela aplicação do sistema de freio instalado. Esta distribuição depende de características construtivas e funcionais do sistema de freios instalado no veículo, segundo ADAS, FONSECA, FERNANDES \& CANALE (1995).

Também compararam o desempenho de freios a tambor e a disco para veículos pesados, GOHRING \& VON GLASNER (1990), concluindo:

- quando aumenta a temperatura inicial e a velocidade de frenagem ocorre nos freios a tambor uma redução de $14 \%$ a mais no torque que nos freios a disco. Sob condições de superaquecimento, os freios a disco chegaram a atingir em testes até $750^{\circ} \mathrm{C}$ com uma redução máxima de $15 \%$ no torque, enquanto os freios a tambor atingindo a temperatura máxima de $580^{\circ} \mathrm{C}$ sofreram uma redução de $51 \%$ no torque de frenagem.

- Como pode ser visto na Figura 2, a eficiência de frenagem de um freio a disco é maior para uma baixa histerese, em relação ao freio a tambor. 


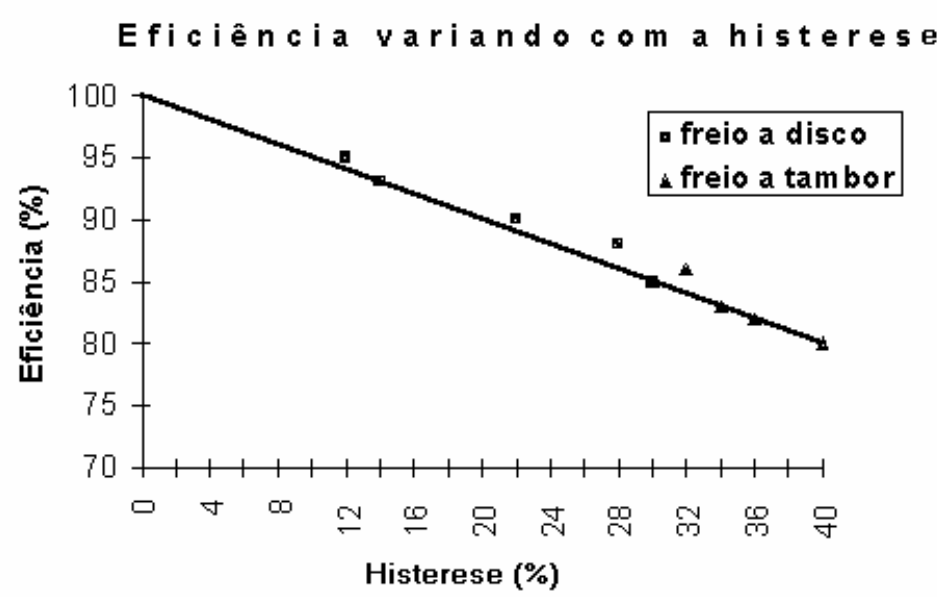

Figura 2 - Eficiência variando com a histerese - GOHRING \& VON GLASNER (1990)

- O freio a disco possui maior eficiência de frenagem que o freio a tambor quando submetidos a excessivas cargas térmicas.

- O veículo equipado com freios a disco em ambos os eixos mostra uma significativa redução na distância de frenagem.

- O veículo com freios a tambor em ambos os eixos sofre redução das forças de frenagem para temperaturas do freio muito altas.

- No veículo com freios a disco somente no eixo dianteiro, o freio a tambor no eixo traseiro tem seu efeito reduzido em virtude da alta temperatura que atinge o disco no eixo dianteiro. Isto muda a distribuição das forças de frenagem. As rodas dianteiras sofrem um alto escorregamento inicialmente e o veículo tende a escorregar para fora da curva. A distância de frenagem é levemente maior que o veículo equipado com freios a disco em ambos os eixos. A comparação entre as diferentes configurações é ilustrada pela Figura 3. 


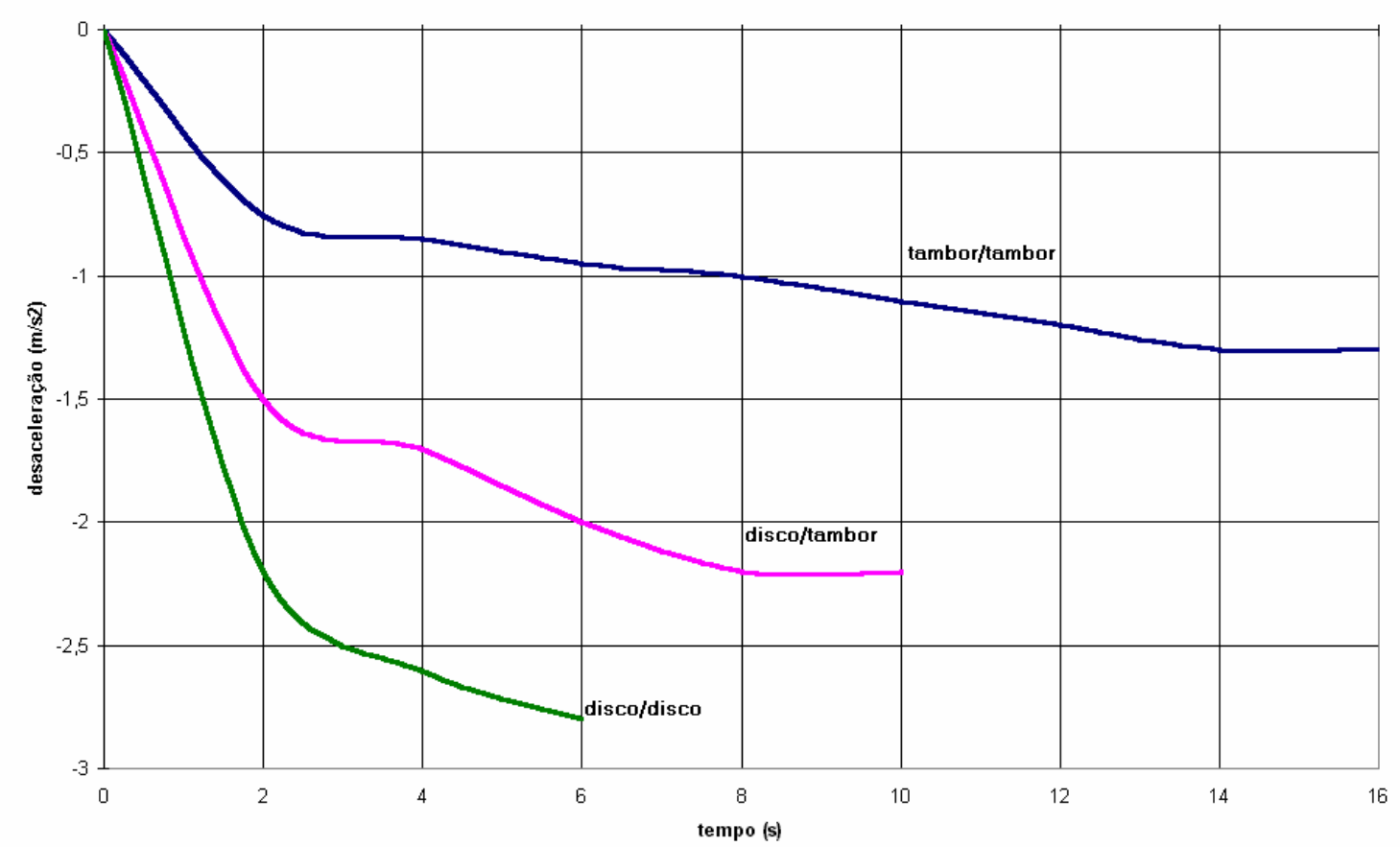

Figura 3 - Desaceleração em relação ao tempo enquanto o veículo faz uma curva GOHRING \& VON GLASNER (1990)

DUSI \& ADAS (2001) destacam ainda que a menor histerese do freio a disco, na prática, representa um comportamento mais previsível para o sistema de freio, uma vez que a relação entre o curso do pedal e a força de frenagem passa a ser mais próxima entre o acionamento e o desacionamento do freio.

Esta menor histerese do freio a disco também traz vantagens na operação do sistema ABS, aumentando seu desempenho. Com a histerese menor, o sistema ABS consegue provocar reduções ou aumentos na força de frenagem variando menos a pressão e conseqüentemente reduzindo assim seu tempo de resposta.

Através da realização de ensaios, PAUL \& BUENO JR. (1999) observaram esta mesma vantagem do freio a disco, a redução do tempo de resposta, como mostra a Figura 4. 


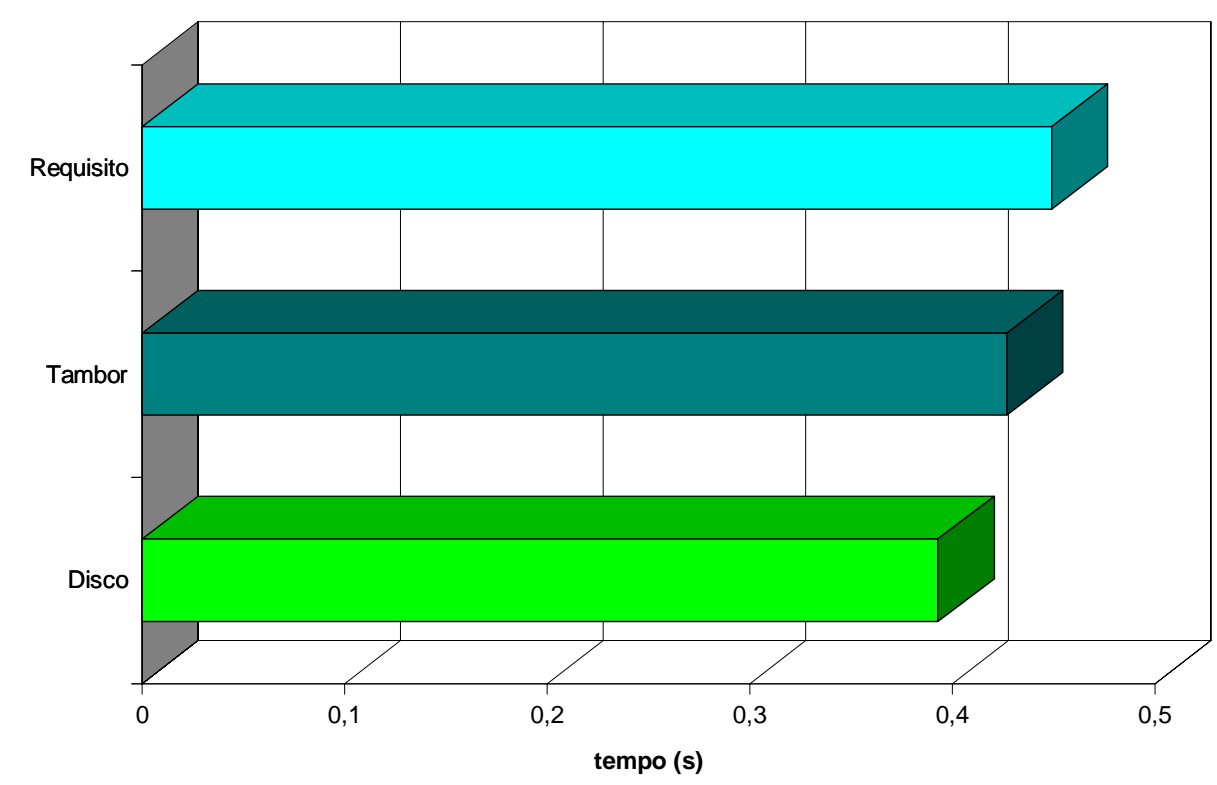

Figura 4 - Tempo de resposta de um freio a disco e outro a tambor, em relação ao valor de requisito ${ }^{1}$ - PAUL \& BUENO JR. (1999)

Segundo DAY \& NEWCOMB (1984), a principal vantagem do freio a disco é que o calor pode ser transferido diretamente para o ambiente pelas faces livres do disco. E através de canais de ventilação podem ainda ser alcançadas melhorias na convecção de calor.

A principal diferença na capacidade de perda de calor entre um disco ventilado e outro sólido consiste no fato de que para uma massa equivalente de metal, o disco ventilado oferece uma maior área de dissipação, conforme destaca INGRAM (1983).

Embora os freios a disco ventilados sejam termicamente mais eficientes do que os discos sólidos, a ventilação interna só começa a ser efetiva quando a velocidade aumenta. Pode-se concluir, portanto que para veículos com baixa velocidade, o disco sólido pode oferecer capacidade de resfriamento próxima à oferecida pelo disco ventilado.

\footnotetext{
${ }^{1} \mathrm{O}$ valor de requisito aqui considerado consta nas normas ABNT MB-3160, MB-3161, NB-1254 e NB-1255 responsáveis pela certificação Contran 777.
} 


\subsection{MATERIAIS DE FRICÇÃO}

No desenvolvimento e projeto do sistema de freios, além das características dimensionais, físicas e térmicas, é fundamental ao projetista o completo conhecimento das características friccionais dos materiais com os quais irá trabalhar.

As propriedades dos materiais de fricção são muito diferentes e geralmente dependem da temperatura. A escolha do material de fricção mais conveniente é essencial para o projeto do freio bem sucedido, mas o projeto do freio também tem um forte impacto sobre o comportamento do material de fricção.

Em análises de freios a disco, HARDING \& WINTLE (1978) observaram a influência importante que a compressibilidade do material de fricção tem no desempenho e segurança do freio.

Na área da engenharia de materiais, muitas pesquisas têm sido feitas a fim de se avaliar os materiais mais apropriados para compor os discos e pastilhas de freio. Entre os principais objetivos destacam-se:

$\Rightarrow$ redução de custo;

$\Rightarrow$ diminuição de peso;

$\Rightarrow$ melhoria nas características de desempenho e segurança.

Em virtude das pesquisas estarem concentradas, em sua maior parte, nas grandes indústrias e da escassez de literatura nessa área, a tecnologia de materiais de fricção é ainda considerada por muitos como "magia negra", a qual deve ser desmistificada, pois como afirma SMALES (1995), modernas técnicas de análise permitem que tais materiais sejam hoje desenvolvidos por uma ciência bem conhecida, o que torna possível a determinação de suas características.

O autor prova sua afirmação através de sua experiência no desenvolvimento e instalação da engenharia de materiais de fricção da Mintex Don Limited, onde modernas técnicas de análise, instrumentação eletrônica e métodos computacionais auxiliam a ciência no desenvolvimento de novas fórmulas para materiais de fricção, considerando as normas e regulamentos vigentes.

NAERHEIM, PAN \& MIN (1999) destacam algumas características importantes dos materiais para freios a disco: 
- grande tempo de vida sem necessidade de manutenção;

- curta distância de frenagem;

- $\quad$ sem produção de ruído;

- sem produzir vibração;

- fricção estável sob todas as condições de frenagem;

- baixo desgaste das pastilhas e discos;

- sem causar danos ao meio-ambiente.

Na Tabela 1, SAUER \& FLIEDNER (2001) mostram um levantamento geral das exigências para aplicações de fricção.

\begin{tabular}{|c|c|c|c|}
\hline $\begin{array}{l}\text { Desempenho/ } \\
\text { Segurança }\end{array}$ & Conforto & $\begin{array}{c}\text { Custo/ } \\
\text { Eficiência } \\
\text { econômica }\end{array}$ & $\begin{array}{c}\text { Meio ambiente/ } \\
\text { Aspectos da } \\
\text { produção }\end{array}$ \\
\hline $\begin{array}{l}\text { Coeficiente de fricção } \\
\mu=f(T, p, v) \\
\text { (resfriamento, umidade, } \\
\text { salinidade) }\end{array}$ & Ruído & Desgaste da pastilha & $\begin{array}{l}\text { Emissões (na produção } \\
\text { e durante a utilização) }\end{array}$ \\
\hline $\begin{array}{l}\text { Coeficiente de friç̧ão } \\
\text { estático }\end{array}$ & $\begin{array}{l}\text { Vibrações do } \\
\text { veículo }\end{array}$ & Desgaste do disco & $\begin{array}{l}\text { Reciclagem (apropriada } \\
\text { para o meio ambiente) }\end{array}$ \\
\hline Propriedades básicas & $\begin{array}{l}\text { Sensibilidade do } \\
\text { pedal }\end{array}$ & Peso & $\begin{array}{l}\text { Poluição do meio } \\
\text { ambiente pelo desgaste } \\
\text { abrasivo }\end{array}$ \\
\hline Dilatação e contração & Força de atuação & Custo de produção & \\
\hline Compressibilidade & Cheiro & $\begin{array}{l}\text { Reciclagem (com custo } \\
\text { moderado) }\end{array}$ & \\
\hline Transferência de calor & $\begin{array}{l}\text { Formação de } \\
\text { fumaça }\end{array}$ & & \\
\hline Resistência térmica & & & \\
\hline Força & & & \\
\hline Trincas, quebras & & & \\
\hline Inflamabilidade & & & \\
\hline
\end{tabular}

Tabela 1 - Exigências para aplicações de fricção - SAUER \& FLIEDNER (2001) 
Segundo RHEE (1974), uma das características desejáveis em um material de fricção automotivo ideal é um coeficiente de fricção constante. Na prática, entretanto, sabe-se que ele varia freqüentemente.

Outra importante característica do material de fricção é sua durabilidade, ou seja, sua expectativa de vida útil.

Altas temperaturas influem nas propriedades mecânicas dos materiais do par de fricção, ativando processos físico-químicos, estruturais, mudança de fase e desgaste, alterando o comportamento do par de fricção.

Como as pressões na superfície e as temperaturas dependem das propriedades termofísicas do material de fricção, tais propriedades podem também afetar o desempenho de fricção dos freios.

A influência da temperatura nas pastilhas de freio foi analisada por TRICHÊS JR., JORDAN, GUGES \& TOUSSI (2001), concluindo que o aumento da temperatura causa variações nas propriedades do material de fricção, sendo que o módulo de elasticidade é o mais afetado, causando um aumento nos fatores de amortecimento da pastilha.

DAY (1988) destaca que as propriedades termofísicas dos materiais de fricção são notavelmente difíceis de medir, por sua dependência da temperatura e do tempo, sua natureza anisotrópica e limitações impostas por sua fabricação.

Segundo DAY, HARDING \& NEWCOMB (1984), pode haver significativas diferenças entre as propriedades do material de fricção novo e usado, particularmente na expansão térmica, um parâmetro que é muito importante na determinação do contato na interface e na distribuição de pressão. Análises químicas de material de fricção usado tem indicado que uma fina camada da superfície (aproximadamente $0,5 \mathrm{~mm}$ ) é carbonizada pela degradação térmica resultante das altas temperaturas na superfície. Tal camada carbonizada ocasiona tensões físicas e baixa condutividade.

Os pesquisadores observaram ainda que o desgaste do material de fricção é diretamente proporcional à pressão na interface e exponencialmente proporcional à temperatura. O problema da distribuição desigual de pressão, segundo TIROVIC \& TODOROVIC (1988), é enfatizado em pastilhas de freios a disco de veículos comerciais pesados, devido a suas grandes dimensões. Tais pesquisadores 
apresentaram uma análise das distorções e distribuições de pressão para uma grande pastilha de freio, usando um modelo tridimensional de análise, com cargas mecânicas e térmicas. Da análise realizada, observaram que altas forças atuando, forças de arrasto de fricção e carregamentos térmicos podem provocar significativas deformações nas pastilhas e uma distribuição desigual de pressão. Isto pode resultar em redução do torque de frenagem, desgaste desigual do material de fricção, altas temperaturas na interface de contato entre disco e pastilha, além de segregação do material de fricção, bem como ruído no freio.

A fim de prever as deformações da pastilha e a distribuição de pressão na interface entre a pastilha e o disco, alguns cálculos foram ainda realizados por TIROVIC \& TODOROVIC (1988), usando a teoria de vigas com fundamentos elásticos. O método de elementos finitos foi usado para calcular as deformações e tensões da pastilha para todos os casos de carregamento (forças atuando, forças de arrasto de fricção e cargas térmicas). Entre os resultados obtidos foi possível concluir que embora as cargas mecânicas causem deformações consideráveis e levantamento das extremidades das pastilhas, a introdução de cargas térmicas foi determinante para o comportamento da pastilha, causando excessiva distorção e altas pressões na interface.

Avaliando ainda as diferenças entre os materiais de fricção, NICHOLSON (1995) destaca a importância de também se considerar os dois distintos mercados dos materiais de fricção nas pesquisas de formulação do material. A formulação para a indústria de autoveículos (equipamento original) deve ser diferente da formulação para o usuário, onde os veículos podem ser novos ou velhos, estar em boas ou más condições, e a mão-de-obra pode ser realizada por bons ou maus profissionais.

Para avaliar o estado técnico do freio de um veículo, SEGAL (1999) desenvolveu um método de diagnóstico baseado na medida da razão de aumento da temperatura das partes de fricção do freio durante a rotação da roda com os freios aplicados sob condições de estado estacionário.

A importância de analisar-se corretamente o material dos freios usados especialmente em ônibus urbanos, antes de adotá-los, é salientada por BARBER \& TUTEN (1986). Embora a velocidade de frenagem seja relativamente baixa, a frequiência de aplicação dos freios é muito grande. Estes dois fatores somados 
dificultam significativamente o resfriamento do sistema de freios, acelerando o desgaste de seus componentes.

\subsubsection{PASTILHA}

NICHOLSON (1995) relata um histórico da evolução dos materiais de fricção, sintetizado a seguir.

Em 1897, Herbert Frood desenvolveu o primeiro material de fricção, que se tratava de uma base de algodão ligada por uma solução de betume. Sua limitação era que o algodão, por se tratar de uma fibra natural, carboniza a $150^{\circ} \mathrm{C}$ e reduz as propriedades de fricção e tensão.

O mesmo inventor introduziu em 1908, uma trama de asbesto, que se tornou a base dos materiais de fricção para as próximas seis décadas.

No início dos anos 20 foi desenvolvida uma fórmula com moldes, utilizando pequenas fibras crisólitas de asbesto, que em função de serem abundantes, promoveram redução no custo.

Resinas flexíveis com alta estabilidade térmica passaram a ser utilizadas nos anos 30. Simultaneamente, outros pesquisadores desenvolveram materiais de fricção vindos da indústria da borracha. Tramas de algodão e depois tramas de asbesto foram sendo recobertas com composição de borracha e então eram trabalhadas nas fábricas de borracha até atingir a espessura necessária. Depois, fibras compostas de borracha e asbesto foram desenvolvidas e laminadas, usando a maquinaria convencional da borracha com somente algumas pequenas modificações.

Nos anos 50 a S. K. Wellman Company introduziu uma resina de liga metálica para as lonas de freio, baseando-se nas experiências com materiais metálicos de fricção usados na aeronáutica. Esta resina era uma mistura de pó de ferro, grafite e ligante. Ela tornou-se mais popular nos anos 70 em freios a disco.

Com o surgimento de novos veículos, nos anos 60 esperou-se mais dos freios e assim muitas empresas passaram a buscar alternativas para o asbesto, já que era o maior constituinte do material de fricção e passou a mostrar algumas limitações, tais 
como: aumento de custo, qualidade variável e suprimento esgotável. Nesta época também se levantou o problema da segurança no uso do asbesto, causando problemas à saúde. Esta somatória de fatores tornou os materiais semi-metálicos mais atrativos.

Entretanto, os semi-metálicos não são ideais para todas as aplicações, pois têm pouca flexibilidade e aumentam a condutividade térmica.

Assim, nos anos 70 os materiais de fricção eram desenvolvidos com fibra de vidro entre outras, substituindo o asbesto. Desde o início dos anos 80 algumas companhias já vêm equipando seus veículos com materiais de fricção à base de fibra de vidro, e sem asbesto.

De qualquer maneira o uso do asbesto ainda continua em alguns países, principalmente pela sua facilidade de obtenção e baixo custo em relação às fórmulas misturando cerâmica, vidro e fibras naturais.

A composição básica das pastilhas de freio é descrita por LIMPERT (1992) da seguinte maneira:

- fibras;

- material de preenchimento;

- ligantes;

- modificadores de fricção.

- Fibras - Provêem a força e rigidez necessárias para as pastilhas. No caso de ressecamento, as fibras mantém a forma prévia do material. Para altas temperaturas no material de fricção as fibras também proporcionam estabilidade térmica. Os materiais de fibra incluem asbesto e palha de aço.

- Material de Preenchimento - São minerais indispensáveis para aumentar a vida da pastilha, preenchendo os espaços e minimizando o custo. Tais materiais podem ser:

* Sulfato de Bário - famoso pelo baixo custo, embora possua uma grande densidade específica. Aumenta um pouco o desgaste e reduz o nível de friç̧ão. Aumenta a densidade e como é relativamente inerte, tem alta estabilidade térmica. 
* Carbonato de cálcio - tem menor densidade específica, sendo necessário menor quantidade, entretanto não é tão resistente ao calor.

* Sílica (dióxido de silício) - é um abrasivo suave e pode aumentar o peso do material de fricção em até $5 \%$.

- Ligantes - São o material aglutinante que mantém os materiais da pastilha juntos. Os ligantes mais comumente usados são os fenolformaldeídos. Os fenolformaldeídos podem ser de dois tipos:

1. Resinas crisol - são mais duras e quebradiças, mas resistem melhor ao calor

2. Novolak - precisa de um agente para completar a cura.

Outras resinas alternativas são:

* Resinas de óleo modificado (de linhaça, de rícino ou de soja) oferecem flexibilidade, aumentam as cargas de fricção e diminuem as características de "fade".

* Resinas de óleo da casca da castanha de caju - aumentam a eficiência e tornam o freio mais silencioso.

* Resinas fenólicas modificadas por elastômeros - oferecem flexibilidade e altos coeficientes de fricção.

* Resinas de crisol - usadas para modificar as resinas fenólicas, tornam a resina mais macia e de cura mais lenta.

* Resinas fenólicas modificadas por óxidos metálicos - aumentam a resistência ao calor antes de iniciar o "fade", além de reduzir os tempos de cura.

* Resinas fenólicas modificadas por ácido bórico - melhoram a resistência ao calor e a limitação do desgaste.

- Modificadores de friccão - Geralmente são elastômeros que proporcionam propriedades mecânicas e resistência ao desgaste, agentes de cura e outros que afetam a uniformidade da fricção. Latão, zinco ou outros metais são adicionados para controlar as propriedades abrasivas e para limpeza total da superfície do disco. 
Alguns tipos comuns de elastômeros são:

* Borracha natural - caiu em desuso devido ao seu alto custo e às características de proporcionar "fade" e exalar um forte cheiro quando aquecida.

* Borracha de Estireno Butadieno - usada em combinação com resinas fenólicas, oferece rigidez e força adicional, além de resistência ao "fade".

* Borracha de Acrilonitrila Butadieno - usada só ou combinada com resinas fenólicas em guarnições flexíveis e oferece melhor resistência ao calor que outras borrachas, auxilia na eficiência e melhora a compressão contra a superfície oposta.

Para aumentar o nível de fricção alguns abrasivos são incluídos nos materiais de friç̧ão. Alguns destes são:

* Óxido de alumínio anidro (alumina) - é um material bastante duro e abrasivo, apresenta estabilidade em altas temperaturas. Uma fina poeira de alumina misturada com uma solução de resina fenólica foi usada para pintar a superfície final da pastilha, desta forma foi possível polir e moldar a superfície do disco durante os primeiros $100 \mathrm{~km}$ de uso, combatendo a baixa fricção sem reduzir a vida da pastilha.

* Óxido de cromo - aumenta a fricção, mas não é comum devido ao alto custo na maior parte do mundo.

* Óxido de zinco - tem algum efeito lubrificante e oferece resistência ao desgaste, entretanto em excesso pode desgastar também o disco.

* Cal (hidróxido de cálcio) - oferece dureza e combate a ferrugem em fórmulas contendo palha de aço e partículas de ferro. Aumenta a estabilidade térmica das resinas de fenolformaldeído, retardando o "fade" até altas temperaturas. Reduz a dilatação e absorve gases durante o processo de cura, reduzindo as laminações necessárias.

* Óxido de cobre - aumenta o nível de friç̧ão, mas não garante a qualidade da superfície oposta, ou seja, o disco.

* Óxido de ferro - os diferentes tipos são usados para aumentar o nível de fricção e dar alguma estabilidade térmica, além de mudar a cor. 
* Óxido de ferro vermelho (hematita) - é um suave abrasivo, usado como agente polidor da superfície.

* Óxido de ferro preto (magnetita) - em fórmulas semi-metálicas é usado para elevar a fricção a frio.

* Óxido de magnésio - usado para aumentar a estabilidade térmica das resinas. No estado fundido aumenta o nível de fricção, pois se torna mais duro e menos reativo.

* Grafite - reduz o nível de fricção, mas melhora o "fade".

* Lascas de latão (62\% cobre e 38\% zinco) - 4\% em peso na fórmula é suficiente para controlar o "fade". Acima desta quantidade, aumenta a condutividade térmica, ajuda a difundir o calor gerado na superfície de frenagem e contribui para prolongar a vida do material. Tende a provocar polimento do disco, limpando depósitos de resíduos. Entretanto, com o aumento do seu custo, as quantidades têm se reduzido nas fórmulas.

* Pó de cobre - aumenta a eficiência, é bom condutor, entretanto em grandes quantidades provoca desgaste.

* Chumbo - inicialmente era utilizado para aumentar o peso, mas também oferece estabilidade friccional em altas temperaturas. No entanto, devido a sua toxidade tem sido retirado de muitas fórmulas.

\subsubsection{Asbesto}

Trata-se de um mineral complexo e único, é um silicato de magnésio hidratado, contendo talco e alguns traços de magnetita. O asbesto é capaz de combinar a resistência ao calor de um mineral com a força e flexibilidade de uma fibra.

Suas fibras são particularmente convenientes para materiais de fricção devido a alguns aspectos:

- Termicamente estável acima de $500^{\circ} \mathrm{C}$, resistente à fusão e retém sua fibra natural acima de $1400^{\circ} \mathrm{C}$. 
- Acima de $500^{\circ} \mathrm{C}$ perde água, mas cria outros silicatos, regenerando a superfície original de fricção. Tal característica é difícil de obter em fibras sintéticas.

- Bom isolador.

- De fácil processo.

- Grande área de superfície para absorver resinas e outros ligantes.

- Apresenta boas tensões, sendo resistente ao cisalhamento.

- Bom preço.

- Grande quantidade disponível. Tem sido extraído no Canadá, sul da África, Itália e Rússia por muitos anos, mas recentemente também tem sido encontrado no Brasil e México.

- Favorece o pouco desgaste do disco.

Entretanto, o asbesto e suas partículas podem ser perigosos para a saúde, e a exposição por um período prolongado pode aumentar o risco de desenvolver doenças como: asbestose, câncer no pulmão ou no aparelho digestivo.

Algumas indústrias já vêm tomando algumas precauções para diminuir o nível de poeira e para evitar a exposição desnecessária ao asbesto, alertando os trabalhadores para sua própria segurança. Em muitos países têm sido estabelecidos padrões para exposição, tendo algumas empresas até mesmo um monitoramento da qualidade do ar no local de trabalho.

Segundo LIMPERT (1992), embora algumas pesquisas sugiram que a poeira de asbesto do freio é pequena demais para causar câncer, o uso de asbesto em freios vem se tornando cada vez mais limitado, sendo já proibido seu uso em alguns países.

HARRISON, LEVY, PATRICK, PIGOTT \& SMITH (1999) concluíram que os cristais de asbesto (asbesto crisólito) são intrinsecamente mais perigosos do que as fibras de aramida, o PVA ou as fibras de celulose e que seu uso continuado em materiais de fricção não é justificado em face de seus substitutos tecnicamente viáveis. 


\subsubsection{Substitutos para 0 asbesto}

NICHOLSON (1995) apresenta alguns substitutos para o asbesto e mostra que a tendência para substituí-lo não é motivada apenas pelas regulamentações que visam a proteção da saúde.

A Alemanha começou a usar palha de aço para substituir as fibras de asbesto durante a Segunda Guerra, quando possuíam pouco asbesto. Usaram tais pastilhas laminadas em aviões, servindo esta como base para as fórmulas desenvolvidas sem asbesto nos anos 80 .

Algumas típicas alternativas avaliadas atualmente são:

- Wollastonite $\left(\mathrm{CaSiO}_{3}\right)$ - possui tamanho de fibras variáveis, dependendo do local de extração e apresenta um custo baixo.

- Vermiculite - trata-se de um mineral, um silicato de alumínio e magnésio hidratado. Resistente ao calor, absorvente e de baixa densidade. Não é fibroso, portanto não acrescenta força física ao produto. Entretanto, é usado como um preenchimento de baixo custo, pois melhora as características de desgaste e reduz o inchaço e o crescimento.

- Mica - se houver um bom ligante entre a mica e a resina, ela irá contribuir para aumentar a força física.

- Fibra de basalto - possui pouca quantidade de ferro e pouco cálcio.

- Fibra cerâmica - alta resistência térmica e baixo custo.

- Poliacrilonitrila - rende seis vezes mais que o asbesto. Possui características que reforçam a força física do material, por isso é usada em freios de veículos pesados.

- Fibras de celulose - tornam o freio mais silencioso e o material mais elástico.

- Poliester - fibra orgânica, mas ainda não é tão boa quanto a poliacrilonitrila.

- Fibra de vidro - tem tido sucesso em substituir o asbesto, mas possui um ponto de fusão muito baixo.

- Fibras de algodão - presentes em muitos materiais de fricção de veículos pesados. 
- Fibras de aramida - possui propriedades que oferecem força e resistência ao calor, além de facilitar na manufatura das fórmulas sem asbesto. Entretanto, o aumento em seu custo fez com que as fórmulas tivessem sua quantidade reduzida.

- Carbono - apresenta muitos atrativos em freios:

$\Rightarrow$ peso reduzido;

$\Rightarrow$ boa condutividade térmica;

$\Rightarrow$ alto calor específico;

$\Rightarrow$ fisicamente forte;

$\Rightarrow$ termicamente estável;

Por possuir pouco peso e excelentes propriedades de absorção de calor, o carbono foi inicialmente utilizado nos aviões, em sua forma grafitizada. Mas o grafite não é necessariamente forte, a não ser que ele seja feito de fibras de carbono, o que aumenta bastante o custo.

Atualmente há muitas novas fórmulas contento carbono, mas não em forma de fibras. Ele melhora a dissipação de calor e a estabilidade friccional, mas não oferece força.

NICHOLSON (1995) destaca a importância de que as fórmulas sejam simples, como muitas que já tem funcionado bem. Para isso pode-se usar asbesto e resina na trama, adicionando material de preenchimento para reduzir o custo ou oferecer características de desempenho, grafite pode ajudar na lubrificação e abrasivos aumentam a fricção. Quaisquer outras substâncias servirão apenas como cosmético no material final.

Há outros aspectos além do desempenho a ser considerado na formulação de um material de friç̧ão. A formulação deve ser acima de tudo operacional, assim torna-se importante analisar os seguintes aspectos:

* segregação de partículas;

* facilidade construtiva;

* bolhas e laminações;

* estabilidade dimensional;

* eliminação de resíduos. 
Para baixas temperaturas de frenagem, a razão de desgaste da pastilha é controlada principalmente pelo abrasivo e mecanismos adesivos, enquanto para altas temperaturas de frenagem, a razão de desgaste aumenta exponencialmente com o aumento da temperatura por causa da degradação térmica do ligante e de outros componentes. Tal razão de desgaste exponencial é freqüentemente acompanhada pelo "fade" do freio, como explicam HARTTER, SCHWARTZ \& RHEE (1974).

NAERHEIM, PAN \& MIN (1999) realizaram avaliações tribológicas a fim de estudar as películas de fricção em freios a disco. Algumas de suas principais conclusões foram:

- para altas temperaturas a película começa a endurecer com elementos que segregam para a superfície;

- a análise química da superfície da película de fricção e a avaliação topográfica das superfícies junto com análises e testes dos materiais, são necessários primeiramente para compreender a formação da película e seu comportamento;

- a formação da película e sua composição química dependem da microestrutura da pastilha e do disco, de suas composições e das temperaturas de contato na interface.

Contanto que as pastilhas de freio mantenham alguma semelhança em seus valores de fricção considerados durante o projeto, sempre ocorrerá o efeito da atuação do motorista sobre o pedal.

Apesar de ocorrer uma certa variação para cada motorista, o desgaste da pastilha deve ser mantido em um mínimo. Sob condições normais de direção, as pastilhas devem durar entre 30 a 50 mil quilômetros.

MOORE \& WATTON (1971) compilaram um histograma de temperaturas de pastilhas de freios em rodovias e usaram isto como base para uma avaliação do desgaste das pastilhas de freio.

MINEGISHI, SHIMIZU, WAKAMATSU \& YOSHIMO (1984) propuseram um método de avaliação da vida da pastilha que pode ser aplicado a qualquer veículo em condições típicas de tráfego. Tomaram como principais fatores 
que afetam a absorção de energia cinética e conseqüentemente a temperatura do freio:

- a freqüência de aplicação dos freios;

- a velocidade do veículo quando os freios são aplicados;

- a velocidade do veículo quando os freios são soltos;

- a razão de desaceleração.

Considerando tais fatores, equacionaram o fator de severidade do freio.

A equação que define o fator de severidade do freio é função da distância percorrida, da velocidade de aplicação do freio e da freqüência de aplicações do freio durante a distância percorrida.

O procedimento adotado para prever o desgaste da pastilha de freio está ilustrado na Figura 5, através de um diagrama esquemático.

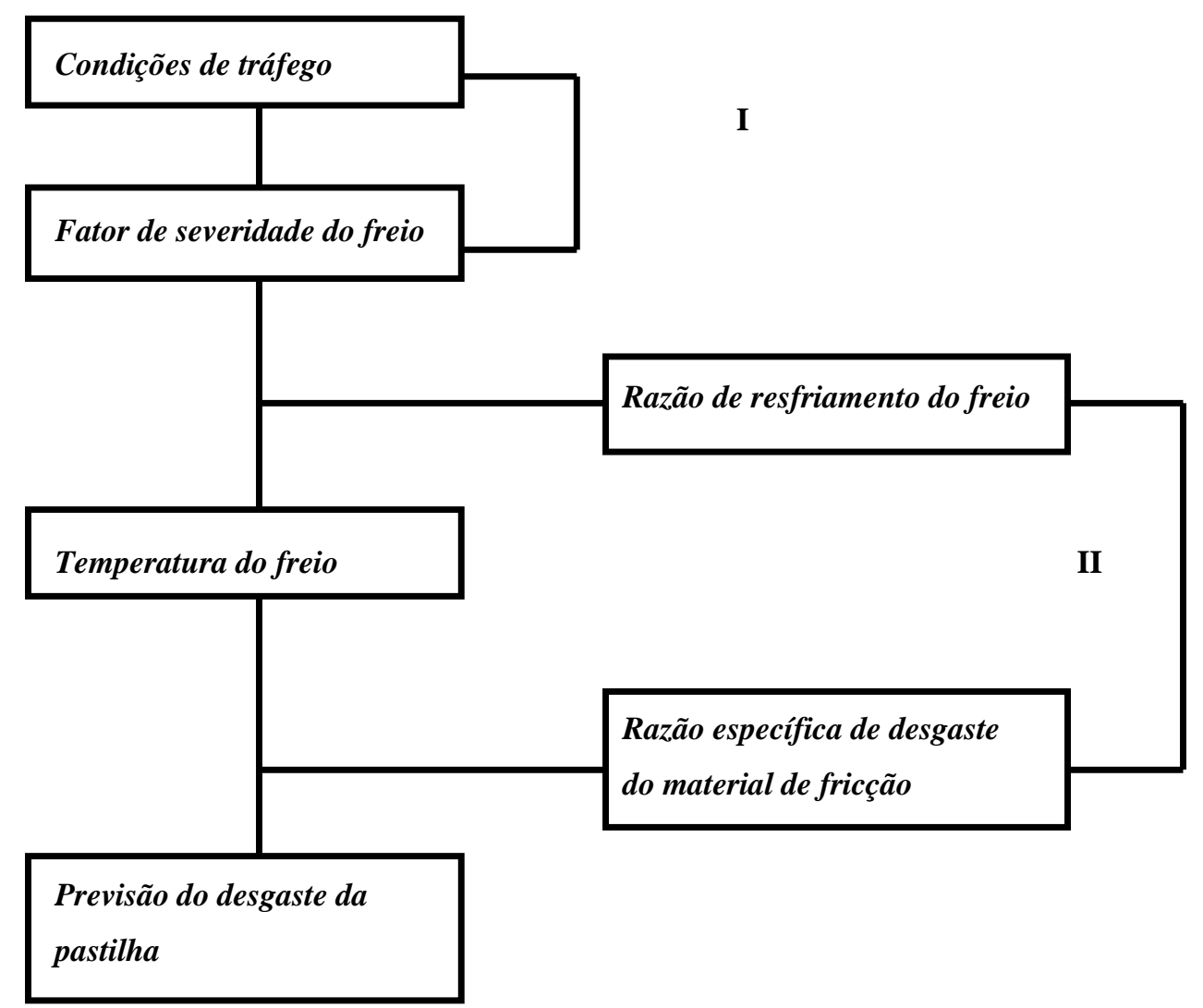

Figura 5 - Procedimento de previsão de desgaste da pastilha. MINEGISHI, SHIMIZU, WAKAMATSU \& YOSHIMO (1984) 
BURKMAN (1962) avaliou as mudanças que ocorrem nas pastilhas sob o efeito da água. Partiu do fato que anormalmente foram obtidos bons resultados de frenagem, com baixa pressão no pedal, durante períodos de alta umidade e anormalmente foi obtida baixa eficiência de frenagem com pressão máxima no pedal, sob condições de inundação. Obviamente concluiu que mudanças drásticas podem ocorrer no coeficiente de fricção das pastilhas. Através de um método de testes em laboratório, medindo a variação do coeficiente de fricção das pastilhas com vários graus de variação de umidade, concluiu que os coeficientes de fricção são mais altos sob condições úmidas do que sob seca, entretanto são extremamente baixos quando os freios são inundados. Foi observado que ocorrem variações entre as pastilhas, sendo algumas muito mais sensíveis à umidade do que outras.

As pastilhas devem ter uma certa quantidade de porosidade para minimizar o efeito da água no coeficiente de fricção, segundo LIMPERT (1992). Estes poros abertos, no entanto, não devem armazenar sal ou resíduos de desgaste que afetam a fricção, pois os materiais metálicos que compõem as pastilhas, em contato com a água irão corroer a superfície do disco.

Além disso, a resistência mecânica das pastilhas tem dupla importância: força para resistir às cargas exteriores e integridade estrutural, que pode ser obtida pela redução das tensões residuais e da expansão térmica, e pelo aumento da resistência ao calor.

Ainda é destacado por NICHOLSON (1995), que diferentes processos de fabricação para a mesma fórmula podem mudar a porosidade, a compressibilidade e a elasticidade entre outras características. Um número maior de fatores deve ser observado quando se desenvolvem fórmulas sem asbesto, visto que este mineral, com suas propriedades únicas, oferece automaticamente muitas destas características. Durante o momento da mistura, na pré-moldagem e durante a cura podem ocorrer falhas que afetem o desempenho e as propriedades físicas do produto. Portanto, torna-se necessário o acompanhamento e a definição detalhada de cada etapa do processo de fabricação do material de fricção. 


\subsubsection{DISCO}

O material dos discos de freio deve ser capaz de resistir à fadiga térmica. Além disso, a grande quantidade de calor gerado durante a frenagem deve ser absorvida e depois dissipada tão rápido quanto possível, como destacam JIMBO, TAKAHIRO, AKIYAMA, MATSUI, YOSHIDA \& OZAWA (1990). Salientam ainda que o material deve ter também uma boa resistência mecânica, ser fácil de usinar, leve, barato e fácil de fundir.

Desde o início dos anos cinqüenta, a maioria dos discos de freio têm sido fabricados em ferro fundido cinzento, material que permite boa resistência às variações térmicas.

O ferro fundido é um material complexo, com características de tensão e deformação não lineares. Como as tensões são afetadas pela distribuição de temperaturas, estas influenciarão no comportamento do metal. O grafite é um dos mais importantes constituintes do metal porque influencia no desgaste, aumenta a condutividade térmica e abaixa o módulo de elasticidade. Assim, a forma e distribuição do grafite são muito importantes. Quando o grafite está sob resfriamento ou segregado pode ocorrer aumento na porção de ferrita livre. No entanto, a matriz deve ser predominantemente perlítica, com no máximo 5\% de ferrita, pois sua baixa dureza e a não uniformidade desta dureza, tornam o metal mais sujeito a riscos. Algumas vezes, pequenas porções de elementos de liga são adicionadas para dar ao ferro fundido as propriedades físicas requeridas à determinada aplicação.

Os ferros fundidos cinzentos pertencem ao grupo de ligas de alto carbono e são caracterizados por apresentarem o grafite na forma lamelar, o que segundo SILVA \& DIEHI (1996) favorece a dissipação térmica, já que na forma lamelar o grafite possui maiores extensões superficiais e maiores pontos de contato entre si. O grafite na forma lamelar também favorece a estabilidade dimensional durante o aquecimento.

As principais características do ferro fundido cinzento são:

- boa condutividade e difusividade térmica;

- facilidade de fabricação; 
- facilidade de usinagem;

- baixo coeficiente de expansão térmica;

- suporta gradientes de temperatura entre a superfície e seu interior;

E conforme ainda destaca MARCON (1999), outra vantagem deste material é que o calor específico é diretamente proporcional à temperatura, possibilitando um aumento na capacidade de absorção de calor nas condições críticas de uso.

Além da quantidade de grafite, também é importante na condutividade térmica, a estrutura da matriz, a qual pode conter:

* Ferrita: apresenta baixa resistência mecânica e dureza, mas possui condutividade térmica levemente maior que a perlita;

* Perlita: apresenta elevada resistência mecânica e dureza, assim como boa usinabilidade e resistência ao atrito;

* Bainita: apresenta alto nível de dureza.

A estrutura da matriz também afeta o coeficiente de expansão térmica. Quando se usa simultaneamente matrizes com diferentes coeficientes, podem ocorrer tensões que provocam trincas.

No caso das matrizes de ferrita e perlita, ocorre o mesmo valor de coeficiente de expansão térmica, não havendo formação de tensões quando misturadas. Já a matriz de bainita tem um coeficiente relativamente maior.

O ferro fundido com grafita vermicular também vem encontrando uma maior utilização em aplicações onde ocorrem condições de resistência mecânica, fadiga térmica e altas temperaturas. Tal material apresenta a grafita em forma de vermes, que confere propriedades mecânicas e térmicas intermediárias entre o ferro fundido cinzento e o ferro fundido nodular.

Segundo CUEVA, TSCHIPTSCHIN, SINATORA \& GUESSER (2000), o ferro fundido com grafita vermicular tem resistência à tração pelo menos 75\% maior e tenacidade $35 \%$ mais elevada que o ferro fundido cinzento. Tem ainda aproximadamente o dobro da resistência à tração e tenacidade e mais de cinco vezes a resistência à fadiga térmica em temperaturas de operação semelhantes quando comparado com o alumínio.

GUESSER \& GUEDES (1997) destacam que os ferros fundidos com grafita vermicular podem conter elementos de liga, sendo comum o uso de molibdênio e de 
altos teores de silício, objetivando melhorar as propriedades a quente, ou adições de titânio, para melhorar a resistência ao desgaste, visando seu potencial de utilização em discos e tambores de freios.

A resistência ao desgaste de um ferro fundido com grafita vermicular, foi estudada por CUEVA, TSCHIPTSCHIN, SINATORA \& GUESSER (2000) visando a utilização deste material em discos de freio. Ensaios foram realizados e os resultados obtidos foram comparados com outros adquiridos em ensaios semelhantes, realizados com três ferros fundidos cinzentos normalmente usados em discos de freio. Tais resultados mostraram que:

- a melhor resistência ao desgaste, medida através da perda de massa, foi apresentada pelo ferro fundido cinzento com alto carbono, seguido do ferro fundido vermicular, de um ferro fundido cinzento típico da classe Fe250 e de um ferro fundido cinzento com titânio;

- os maiores valores de força de atrito foram alcançados pelos materiais que mais se desgastaram, ou seja, nesta ordem: ferro fundido com titânio, ferro fundido Fe250, ferro fundido vermicular e ferro fundido de alto carbono;

- as maiores temperaturas de contato foram atingidas pelo ferro fundido vermicular, seguido do ferro com titânio, o ferro Fe250 e do ferro de alto carbono.

Os pesquisadores salientam ainda que os carbonitretos de titânio são partículas muito duras dispersas na matriz metálica (relativamente mole) e durante o processo de frenagem se desprendem, ficando algumas engastadas na superfície da pastilha, e atuando como partículas abrasivas que aceleram o desgaste dos discos. Já os valores de atrito e desgaste medidos nos discos de Fe250, mostram que este material é o que apresenta a melhor combinação de propriedades de frenagem, pois mesmo sofrendo desgaste maior que o ferro fundido com alto carbono e o vermicular, teve um comportamento muito uniforme durante todos os ciclos de frenagem, com alta força de atrito e baixas temperaturas de funcionamento.

Através de ensaios em bancada, SARTORI (1972) concluiu que sob o ponto de vista da temperatura máxima atingida, os materiais bons condutores de calor 
levam vantagem, mas sob o ponto de vista da freqüência das frenagens, o tipo de material influi pouco.

Uma investigação analítica sobre a otimização térmica do projeto do freio a disco de um caminhão foi feita por SCHWARTZ, HARTTER, RHEE \& BYERS (1975). Através de tal estudo foram analisados as temperaturas e o fluxo de calor, enquanto o material do disco e suas dimensões eram variados. Neste caso, somente o disco foi considerado, desprezando-se os efeitos da pastilha e do caliper.

A análise foi realizada nas seguintes etapas:

- um modelo térmico analítico do disco experimental foi desenvolvido;

- o modelo foi comparado com testes em dinamômetro de ambos os projetos de disco, de cobre/cromo e de ferro fundido cinzento;

- modificações geométricas foram então executadas no modelo para melhorar o projeto.

Um estudo das propriedades químicas e físicas do carbono relacionadas ao desempenho de freios foi realizado por BLANCO, BERMEJO, MARSH \& MENENDEZ (1997).

Tais pesquisadores destacam algumas propriedades dos materiais compósitos de carbono que interessam ao sistema de freios.

Em relação aos carbonos grafíticos:

- São refratários e não se fundem a temperaturas abaixo de $3000^{\circ} \mathrm{C}$;

- Tem excelentes coeficientes de condutância térmica (conduz o calor friccional para fora da superfície do freio);

- Tem coeficientes de fricção que mudam pouco com a temperatura da superfície (quando seco);

- Tem alta capacidade térmica (armazenamento de energia gerada para temperaturas mínimas)

- Oferecem fragmentos interfaciais para criar uma superfície friccional, por causa das propriedades de segmentação dos cristais de grafite;

- Não se fadigam como ocorre com os metais.

E ainda, os compósitos de carbonos grafíticos oferecem materiais friccionais e estruturais ao mesmo tempo, no interior do disco de freio. 
Outros materiais também têm sido avaliados para a fabricação de discos. NEITZEL, BARTH \& MATIC (1994), assim como GRIEVE, BARTON, CROLLA \& BUCKINGHAM (1998) através de testes em veículos e em laboratório observaram que freios a disco, compostos por uma matriz metálica de alumínio oferecem significativa vantagem em peso, comparados com o disco tradicional de ferro fundido, mas têm a desvantagem de suportar uma temperatura máxima de operação muito menor, tornando-se ainda necessário avaliar cuidadosamente os aspectos térmicos, o desempenho tribológico, as tensões, além dos custos envolvidos.

De maneira geral, o material do disco de freio deve atender aos seguintes requisitos:

$\Rightarrow$ resistência ao desgaste - não deve ultrapassar determinado limite, de forma que se evite a corrosão dos detritos de desgaste e de materiais depositados durante frenagens drásticas;

$\Rightarrow$ resistência à umidade - para que não ocorra corrosão do disco;

$\Rightarrow$ resistência mecânica - para suportar os esforços e fatores externos à frenagem;

$\Rightarrow$ resistência a trincas térmicas - deve manter a integridade estrutural quando submetido ao superaquecimento;

$\Rightarrow$ facilidade de fabricação - para que seja possível manter a acuracidade do processo, assim como reduzir o custo;

$\Rightarrow$ capacidade de amortecimento - deve absorver vibrações resultantes das tensões cíclicas por atrito, transformando a energia mecânica em calor. Entretanto, vibrações durante a frenagem são causadas por flutuações do torque de frenagem que resulta de discos de freios com espessuras não uniformes. Tais variações de espessura podem ser decorrentes de defeitos de fabricação e manutenção ou pelo depósito de material de guarnição desprendido.

$\Rightarrow$ condutividade térmica - dissipar rapidamente o calor gerado durante a frenagem; $\Rightarrow$ eficiência de frenagem - o coeficiente de fricção do disco não deve sofrer grandes variações quando submetido a altas temperaturas. 
Em situações normais de uso, o ferro fundido cinzento tem atendido bem estas necessidades, sofrendo alguma alteração nas porcentagens dos elementos de liga constituintes, conforme a aplicação mais específica do veículo.

Entretanto, em veículos freando repetidamente em altas velocidades têm surgido trincas na superfície do disco.

Através de uma análise por elementos finitos, JIMBO, MIBE, AKIYAMA, MATSUI, YOSHIDA \& OZAWA (1990) observaram que tais trincas são geradas no estágio inicial da frenagem, resultado do gradiente elevado entre as temperaturas da superfície e do interior do disco. Tal diferença de temperatura diminui ao final da frenagem.

Algumas medidas podem ser adotadas para reduzir o gradiente elevado entre a superfície e o interior do disco, tais como:

- Acrescentar dutos de ar para resfriamento do sistema, o que, entretanto impõe grandes restrições ao projeto do veículo;

- Usar discos de grande tamanho, aumentando sua capacidade térmica, o que torna o sistema mais pesado, dificultando sua montagem e manutenção, além de elevar o custo substancialmente, pelo maior consumo de material.

Desta forma, tais pesquisadores desenvolveram um tipo de ferro fundido que além de satisfazer os requisitos comuns ao ferro fundido cinzento tradicional, também é resistente às trincas térmicas no superaquecimento.

Como descrito anteriormente, o grafite contribui para a condutividade térmica, assim a melhor maneira para que se aumente a quantidade de grafita, é aumentar a quantidade de carbono.

Entretanto, quando há muito carbono, a resistência do material é reduzida, tornando-se necessário adicionar uma liga ao material, em quantidade pequena, para não alterar a condutividade térmica. O melhor elemento de liga encontrado foi o molibdênio, pois não interfere na grafitização como o vanádio e o cromo e não traz aumentos de custo significativos.

Assim, JIMBO, MIBE, AKIYAMA, MATSUI, YOSHIDA \& OZAWA (1990) concluíram que a composição básica do material do disco é um ferro fundido com alto carbono, baixo silício e adição de molibdênio. 
Também foi feita uma avaliação de discos de freio com diferentes composições, por MARCON (1999), utilizando um dinamômetro inercial e simulando diferentes situações de frenagem, tornando possível indicar qual a melhor composição para cada aplicação específica do sistema de freios.

\subsection{MODELAGENS TÉRMICAS}

Muitas técnicas foram utilizadas para que através de testes comparativos fossem encontradas melhores soluções para os problemas térmicos no sistema de freios. OLIVEIRA, ANTONELLI \& VANZETTI (1993) desenvolveram uma destas técnicas e realizando testes comparativos em dinamômetro inercial e também na pista, contrariaram um antigo conceito que defende a redução da dimensão do freio como causador de aumento na temperatura. Através de ensaios observaram que a redução do freio em caminhões pode ser uma forma de reduzir o calor, permitindo que haja um maior espaço para o fluxo de ar refrigerá-lo.

A variabilidade nas características dos freios pode parecer limitar a utilidade das predições computacionais. Entretanto, tal variabilidade reflete-se nos resultados dos testes, fazendo com que haja um projeto de eficiência proporcional.

Torna-se necessário ainda que se tomem os diferentes freios disponíveis, considerando a evolução dos sistemas de freios e a previsão de seu desempenho. Desta forma, uma simulação computacional pode ser uma ferramenta importante para estudar a influência das variações das características dos freios no desempenho dos veículos na frenagem.

O motivo para se observar diferentes modelos é uma questão de preferência pela investigação teórica ou pela experiência. E visto que, ambos tipos de modelos já existem de forma prática, eles devem ser comparados em relação ao custo, à facilidade de uso e à taxa de aplicação, entre outros, a fim de encontrar-se a melhor relação entre custo e benefício para cada projeto. 
Os efeitos da transferência de calor no sistema de freios foram avaliados por MORGAN \& DENNIS (1972), que através de experimentos feitos em laboratório mediram os coeficientes de transferência de calor, desprezando, no entanto, a radiação. Através de um modelo desenvolvido em elementos finitos puderam prever as temperaturas no disco de freio. Embora não considerassem algumas variáveis e sua modelagem se apresente sem muito detalhamento, os resultados foram importantes para avaliar, por exemplo, o fenômeno de fade em caminhões.

O modelo matemático desenvolvido por GARRO, GAVELLO \& ROSSI (1981) para analisar o transiente térmico do freio a disco é baseado nas operações mostradas na Figura 6, partindo da definição das propriedades do material e culminando com a deformação térmica do disco. Tal modelo não atingiu uma boa relação custo/benefício, pois devido ao seu grande tamanho, o modelo atingiu um elevado custo operacional. No entanto, como ofereceu resultados com boa acuracidade teve grande aplicação em estudos fenomenológicos.

Um modelo é apresentado por DAY \& NEWCOMB (1980), o qual incorpora a maioria dos parâmetros do par de fricção em uma frenagem usando o método de elementos finitos. Tem sido mostrado como os efeitos térmicos, mecânicos e de desgaste no par de fricção mudam a distribuição de temperatura e os padrões de contato durante a aplicação dos freios. Destacam que o processo de desgaste é responsável por uma importante contribuição na variação do contato na superfície de friç̧ão.

SANTINI, KENNEDY \& LING (1976) realizaram uma análise das temperaturas, fricção, desgaste e condições de contato que ocorrem em freios a disco sujeitos a altas cargas de energia. A superfície do disco e regiões próximas foram monitoradas para várias posições do caliper, com o coeficiente de fricção e os níveis de desgaste também sendo determinados.

Os pesquisadores puderam observar que o contato na superfície de fricção não era uniforme, com áreas constantemente deslizando devido à expansão térmica não uniforme e ao desgaste. O efeito do resfriamento externo e modificações do projeto em fricção, desgaste e temperaturas foram também investigados. Descobriram desta forma que significantes reduções na temperatura da superfície e no nível de desgaste podem ser atingidas sem redução da fricção, modificando-se o 
projeto do suporte da pastilha para que ela acomode-se melhor, resultando em condições de contato uniformes na superfície de fricção.

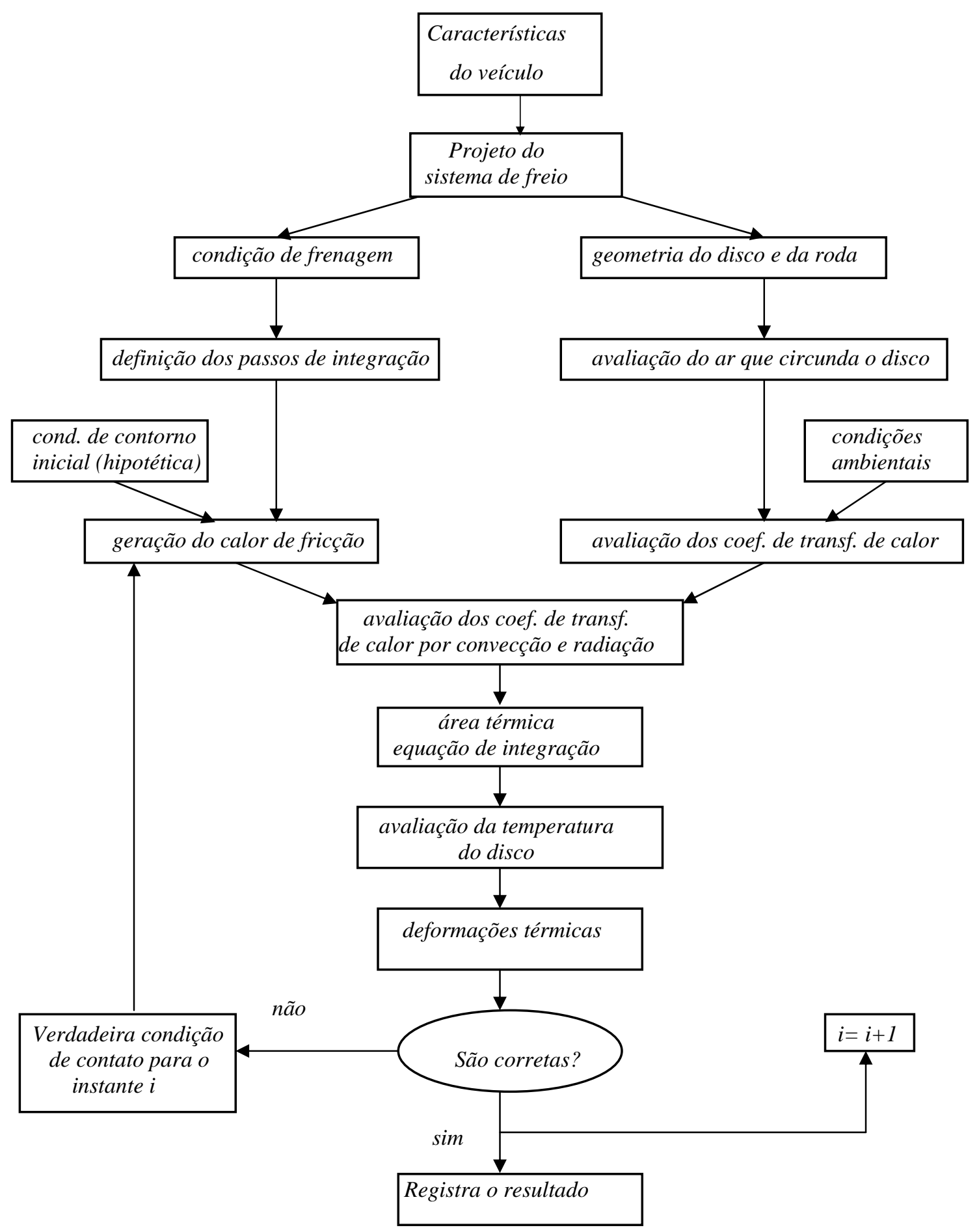

Figura 6 - Fluxograma da análise térmica - GARRO, GAVELLO \& ROSSI (1981) 
O problema de contato no freio a disco foi também avaliado por SAMIE \& SHERIDAN (1990), que iniciaram seu trabalho analisando o comportamento mecânico do caliper a fim de compreenderem melhor os fatores que influenciam na distribuição de pressão entre disco e pastilha.

DAY, TIROVIC \& NEWCOMB (1991) avaliaram através de uma análise de contato disco/pastilha, pelo método de elementos finitos, que pressões uniformes na superfície de fricção são muito importantes para minimizar os problemas térmicos.

A abordagem conjunta do problema térmico e friccional aplicada a freios a tambor de veículos comerciais foi salientada por DAY, HARDING \& NEWCOMB (1984) como de fundamental interesse ao projeto de freios, oferecendo informações mais detalhadas, relacionando ambos os carregamentos (mecânico e térmico). Em seu trabalho utilizaram um modelo em elementos finitos, avaliando o comportamento mecânico de desgaste dos materiais e o desempenho térmico, usando para isso coeficientes de fricção e de transferência de calor calculados por relações empíricas de resfriamento convectivo.

Uma simulação em freio a disco aeronáutico, sujeito a altas cargas, foi feita por KENNEDY JR. \& LING (1974). Tal análise térmica mostrou que a distribuição da temperatura transiente no disco de freio pode ser determinada mais acuradamente pelo uso da análise termomecânica do que por uma análise convencional que assume as condições de contato constantes. Concluíram ainda que baixas temperaturas em um freio a disco podem ser atingidas pelo aumento da condutividade do disco e, especialmente pelo aumento da capacidade térmica dos componentes aquecidos.

FUKANO \& MATSUI (1986) primeiramente avaliaram teoricamente o fenômeno de temperatura no disco de freio considerando os dados experimentais de estudos realizados anteriormente nesta área. A partir do resultado desta análise, desenvolveram uma técnica de simulação computacional com possibilidade para quantificar em condições contínuas, as características transientes de temperatura e 
desempenho de cargas térmicas. A Figura 7 ilustra o caminho de projeto desenvolvido.

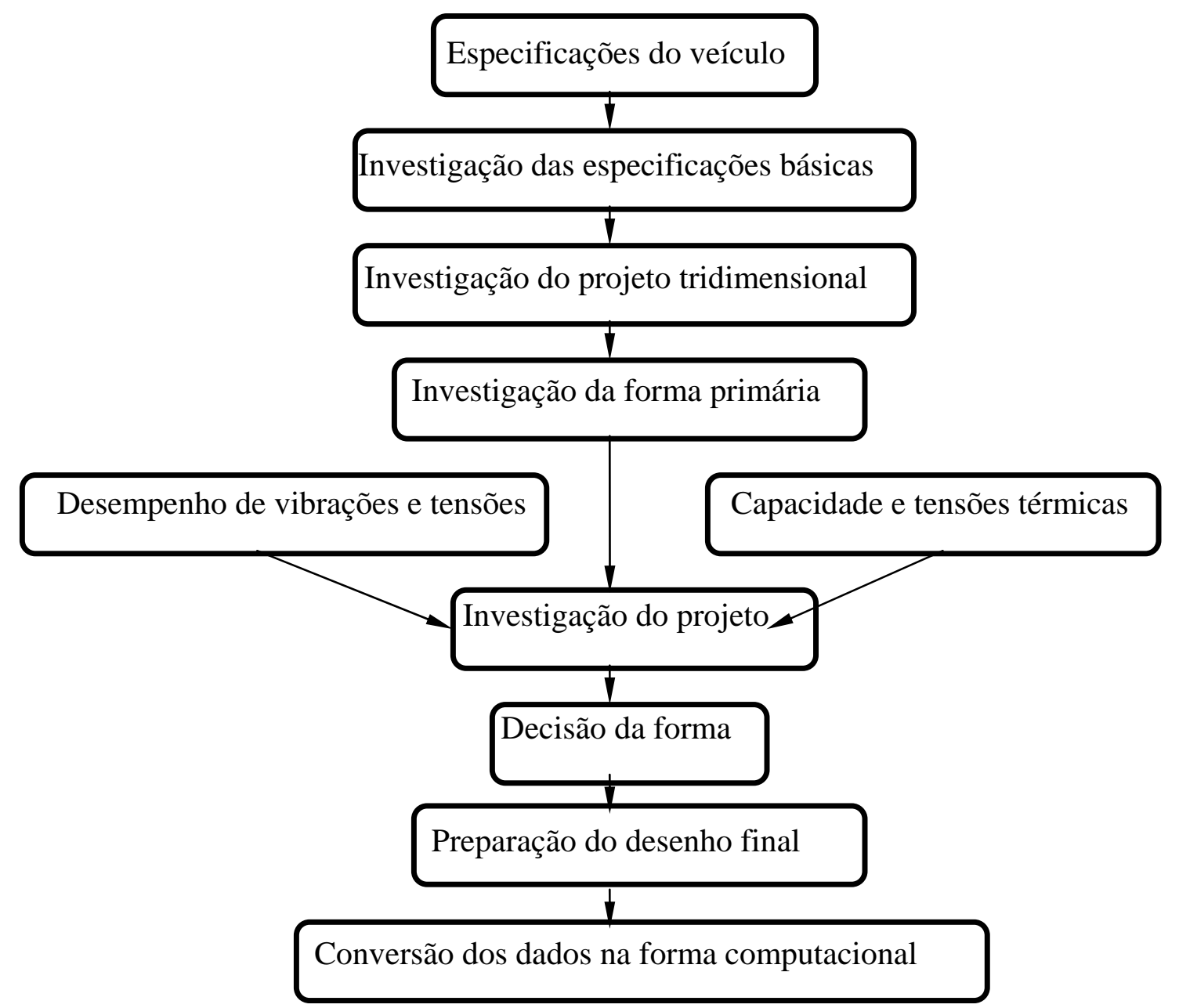

Figura 7 - Sistema de projeto integrado para discos de freio - FUKANO \& MATSUI (1986)

O trabalho desenvolvido por SHERIDAN, KUTCHEY \& SAMIE (1988) apresenta quatro diferentes modelagens para análise térmica de freios a disco. Tais modelos abrangem desde um simples modelo de parâmetros agrupados até um modelo tridimensional complexo, os quais apresentam-se mais adequados conforme as necessidades de projeto e desenvolvimento. 
As temperaturas transientes mais críticas no disco podem ser avaliadas por um modelo de parâmetros agrupados, já o modelo unidimensional além das temperaturas críticas, pode mostrar os picos de temperatura na face de contato. É possível modelar as entradas do sistema de freios obtendo-se as temperaturas durante diversas paradas através de um modelo bidimensional, enquanto um modelo tridimensional complexo pode oferecer a distribuição detalhada de temperatura para qualquer seqüência de frenagens.

O modelo de parâmetros agrupados para o disco pode somente oferecer informações referentes às temperaturas máximas ou médias no disco inteiro.

Entretanto, esta é uma ferramenta extremamente válida durante o estágio preliminar da definição da medida do disco no projeto.

O modelo transiente unidimensional oferece informações referentes ao aumento da temperatura relativa da superfície para o aumento da temperatura máxima em qualquer tempo durante a frenagem.

A suposição que a distribuição de temperatura para o disco é simétrica no plano de rotação permite que apenas metade do disco seja incluída no modelo.

Do modelo térmico unidimensional espera-se um nível de acuracidade satisfatório para o processo preliminar do projeto.

$\mathrm{Na}$ modelagem térmica bidimensional, diferentes modelos foram desenvolvidos para os vários componentes do sistema de freio, onde o tipo e a complexidade de cada modelo é baseado em quão significante é sua contribuição para o desempenho térmico do freio.

Um modelo 2D do disco foi desenvolvido primeiramente para calcular as temperaturas dentro do disco ventilado, assim como as perdas por convecção das faces do disco. Diferentes coeficientes de transferência de calor são descritos para cada superfície, baseado nas várias correlações empíricas encontradas na literatura.

Uma solução por diferenças finitas é usada para resolver o problema de condução de calor em estado estacionário do disco 2D.

Foi ainda construído um modelo tridimensional do disco por elementos finitos. Tal modelo pode mostrar o comportamento térmico do disco tanto em frenagens de emergência como para múltiplas frenagens. No entanto, tal modelo 
necessita de dados acurados do material e das propriedades do fluido, do coeficiente de transferência de calor convectivo e da proporção de energia que entra no sistema.

Um sistema de simulação desenvolvido por GOHRING \& VON GLASNER (1988) auxilia na discussão de resultados para o desenvolvimento veicular. A Figura 8 ilustra o conceito de tal sistema, onde um teste padrão para o pneumático estabelece o pneu para a superfície de rodagem, com o auxílio de um dinamômetro com multi-eixos de frenagem, as forças nas rodas são medidas simultaneamente, e o balanceamento de frenagem nas rodas é determinado por um teste padrão servohidráulico.

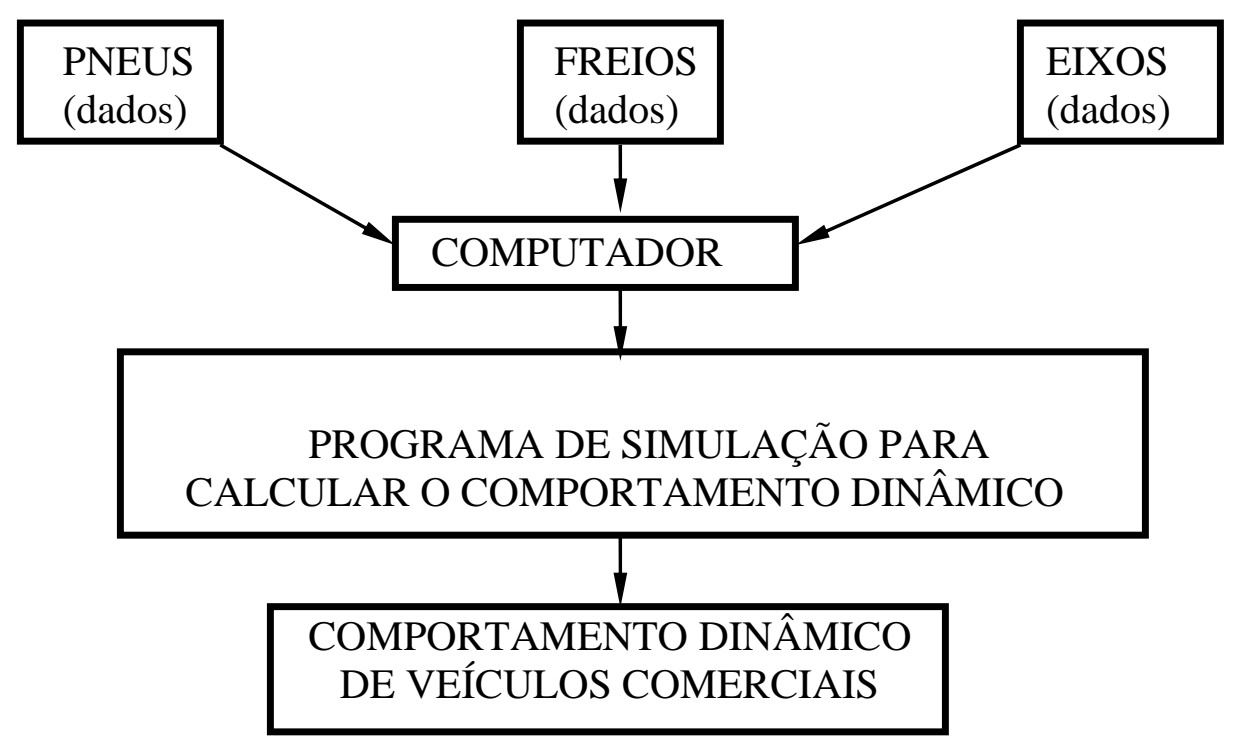

Figura 8 - Sistema de simulação - GOHRING \& VON GLASNER (1988)

HIGHLEY (1971) mostra técnicas para determinar as características térmicas dos discos de freios, confrontando teoria e testes de pista. Foram desenvolvidos e definidos os coeficientes de calor armazenado, de resfriamento e de dissipação de calor que descrevem as características térmicas dos discos de freio.

O termo "coeficiente de calor armazenado" (Cs), foi usado para substituir o termo W.C, que relaciona o peso e o calor específico, considerando na prática as variações do calor específico. Além disso, no tambor ou disco de freio, o coeficiente 
de transferência de calor não foi assumido uniforme, substituindo o termo A.h, que relaciona a área exposta com o coeficiente de transferência de calor, pelo "coeficiente de dissipação de calor” (Cd). Para definir a razão entre o coeficiente de calor dissipado e o coeficiente de calor armazenado foi adotado o "coeficiente de resfriamento" (b).

$$
\mathrm{b}=\mathrm{Cd} / \mathrm{Cs}
$$

A temperatura do ar resfriando foi assumida como "temperatura de estabilização” (Ts), e definida como a temperatura encontrada para tambor ou disco depois de um tempo infinito de resfriamento.

Técnicas de testes para obter valores numéricos foram descritas em detalhes, e exemplos de ensaios foram mostrados. Testes de descida de serra foram realizados para obter-se as forças de resistência do ar e de resistência ao rolamento. Os testes de repetidas frenagens foram realizados para obter-se os valores de temperatura inicial para uma série de paradas. Já os testes de resfriamento para diferentes velocidades foram realizados para determinar o coeficiente de resfriamento (b) como uma função da velocidade e para determinar a temperatura de estabilização. Além disso, foi ainda destacado o uso do coeficiente de resfriamento como instrumento para simulação do veículo usando um freio em dinamômetro.

Os aspectos e variáveis avaliados por HIGHLEY (1971) podem ser sintetizados na Figura 9.

Experimentos foram realizados por RAMACHANDRA RAO, RAMASUBRAMANIAN \& SEETHARAMU (1988), em dinamômetro inercial, conforme sugerido por NEWCOMB (1958) e HIGHLEY (1971) para obter um valor médio do coeficiente de transferência de calor por convecção para freio a tambor de um caminhão. A simulação da distribuição de temperatura no tambor de freio foi feita usando o método de elementos finitos. 


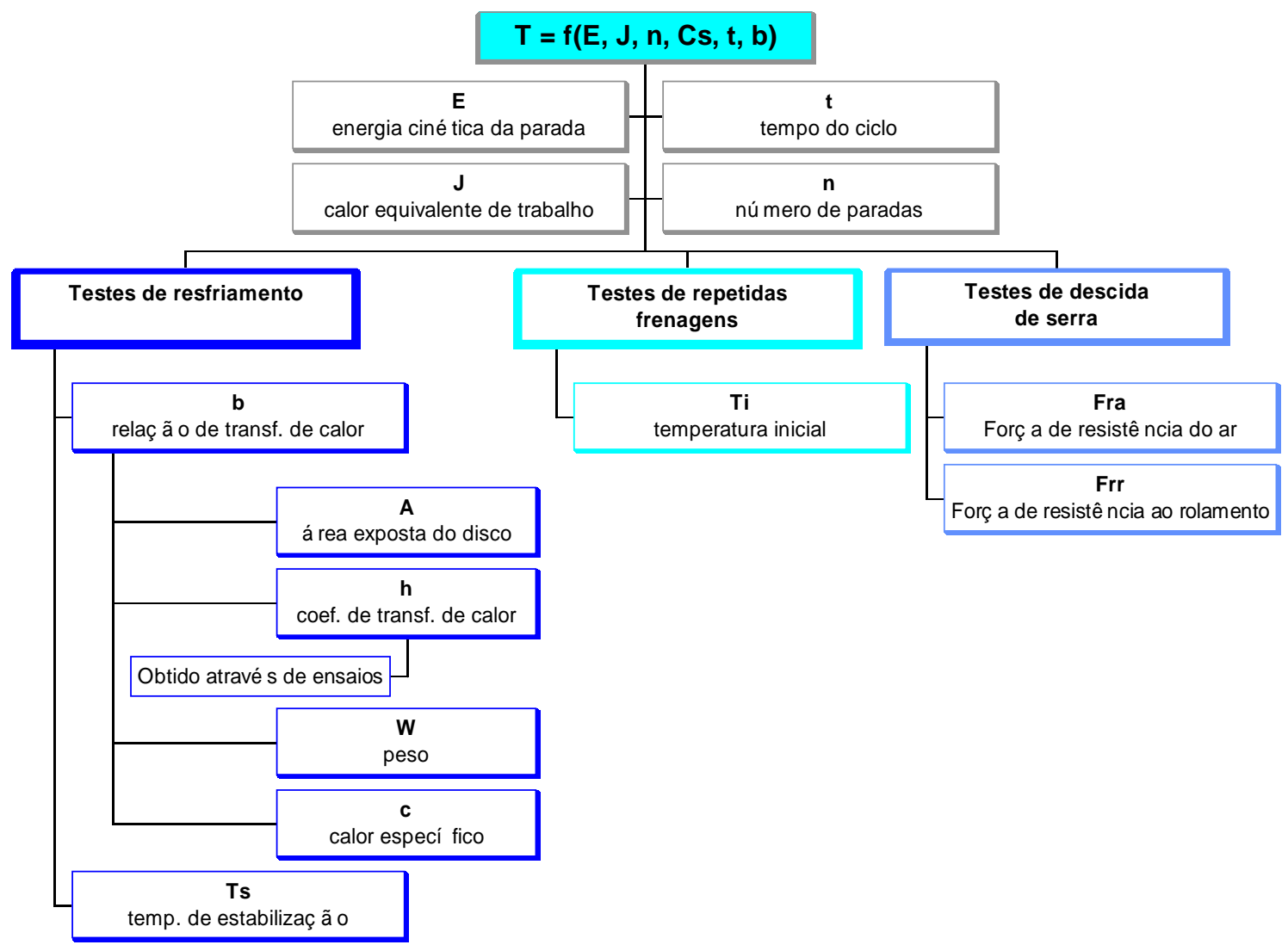

Figura 9 - Modelagem térmica do sistema de freios - HIGHLEY (1971)

Uma técnica capaz de mostrar a variação de calor transferido no sistema de freios, e o coeficiente de transferência de calor como uma função da velocidade do veículo foi desenvolvida por RENFROE (1990). Para isso, considerou parâmetros experimentais tais como: a temperatura no freio, a velocidade do veículo e o torque de frenagem, variando amplamente as condições operacionais. Através de um sistema de aquisição de dados computacional e métodos estatísticos de análise por regressão foram desenvolvidas as equações matemáticas que relacionam tais parâmetros experimentais. Destas equações foi possível formar uma função nãolinear de todas as variáveis modeladas no sistema, específica para o veículo considerado. 
Através de seu trabalho, INGRAM (1983) mostrou a necessidade de estudarse cuidadosamente o balanço entre a melhoria da capacidade térmica evitando, no entanto, um processo de fabricação complexo. Considerou também em sua análise os efeitos de condução, convecção e radiação, além de assumir o calor constante na superfície de frenagem.

Foram ainda realizados ensaios, comparando os coeficientes de transferência de calor variando com o tipo de disco e com a velocidade. Os resultados podem ser observados na Tabela 2.

\begin{tabular}{|l|l||r||r|}
\hline \multirow{4}{*}{$\mathbf{v}=\mathbf{5 m} / \mathbf{s}$} & \multicolumn{1}{|c||}{ Disco Sólido } & \multicolumn{1}{|c|}{ Disco Ventilado } \\
\cline { 2 - 4 } & Condução & $30 \%$ & $22 \%$ \\
\cline { 2 - 4 } & Conveção & $34 \%$ & $51 \%$ \\
\cline { 2 - 4 } & Radiação & $36 \%$ & $27 \%$ \\
\cline { 2 - 4 } & Total & $3,05 \mathrm{KW}$ & $4,1 \mathrm{KW}$ \\
\hline \hline \multirow{3}{*}{$\mathbf{v}=\mathbf{2 0 m} / \mathbf{s}$} & Condução & $18 \%$ & $11 \%$ \\
\cline { 2 - 4 } & Conveçãa & $60 \%$ & $75 \%$ \\
\cline { 2 - 4 } & Radiação & $22 \%$ & $14 \%$ \\
\cline { 2 - 4 } & Total & $5,1 \mathrm{KW}$ & $8,1 \mathrm{KW}$ \\
\hline
\end{tabular}

Tabela 2 - Variação da quantidade de calor dissipado variando com a velocidade e com o tipo de freio a disco - INGRAM (1983)

Um método de avaliação de freios foi também sugerido por INGRAM (1983), o qual assume que a massa do veículo é o principal critério que influencia a energia gerada no freio. Desta forma, sugere que a relação entre a área da superfície total de frenagem e o peso bruto do veículo é uma comparação satisfatória entre várias configurações de freios. Para comparar a vida útil de pastilhas em diferentes tipos de freios, sugere ainda que basta multiplicar a proporção de vida útil pela proporção do volume específico da pastilha (relação entre o volume total da pastilha e o peso bruto do veículo). 
Para otimizar o resfriamento do freio a disco, o fluxo de ar ao redor e através do disco foi simulado por KRÜSEMANN \& SCHMIDT (1995). O freio de roda foi modelado como um elemento tridimensional usando um programa computacional fluidodinâmico e como resultado algumas modificações geométricas foram introduzidas no projeto.

Utilizando o mesmo programa computacional, KRÜSEMANN, URBAN \& ZAJCW (1997) obtiveram uma distribuição aproximada dos coeficientes de transferência de calor nas superfícies do freio a disco. Os cálculos de temperatura foram aplicados em um modelo de elementos finitos bidimensional, avaliando e transferindo o coeficiente de transferência de calor por convecção como parâmetro de resfriamento aproximado.

Um modelo de elementos finitos, bidimensional usando um algoritmo termomecânico foi usado por BENSEDDIQ, WEICHERT, SEIDERMANN \& MINET (1996) para prever a variação da superfície de contato e seu efeito na distribuição de temperaturas na interface entre o disco e a pastilha de freios a disco para ferrovias.

O fluxograma na Figura 10 descreve o algoritmo:

1. O cálculo do contato inicial dá as condições de contato efetivo da pastilha para a pressão nominal. A distribuição de pressões é então usada para calcular a distribuição do fluxo de calor no cálculo térmico transiente durante o primeiro passo de tempo.

2. A geometria é então considerada para avaliar o desgaste, o qual é calculado usando o critério de energia.

3. Para o tempo $t+\Delta t$, o contato é calculado da variação de geometria depois de $\Delta \mathrm{t}$ segundos de frenagem, considerando as distorções térmicas. A atual distribuição de pressão e a distribuição de fluxo de calor são então calculadas na análise térmica de $\mathrm{ti}=\Delta \mathrm{t}$ para $\mathrm{tf}=\mathrm{ti}+\Delta \mathrm{t}$, e assim sucessivamente. 


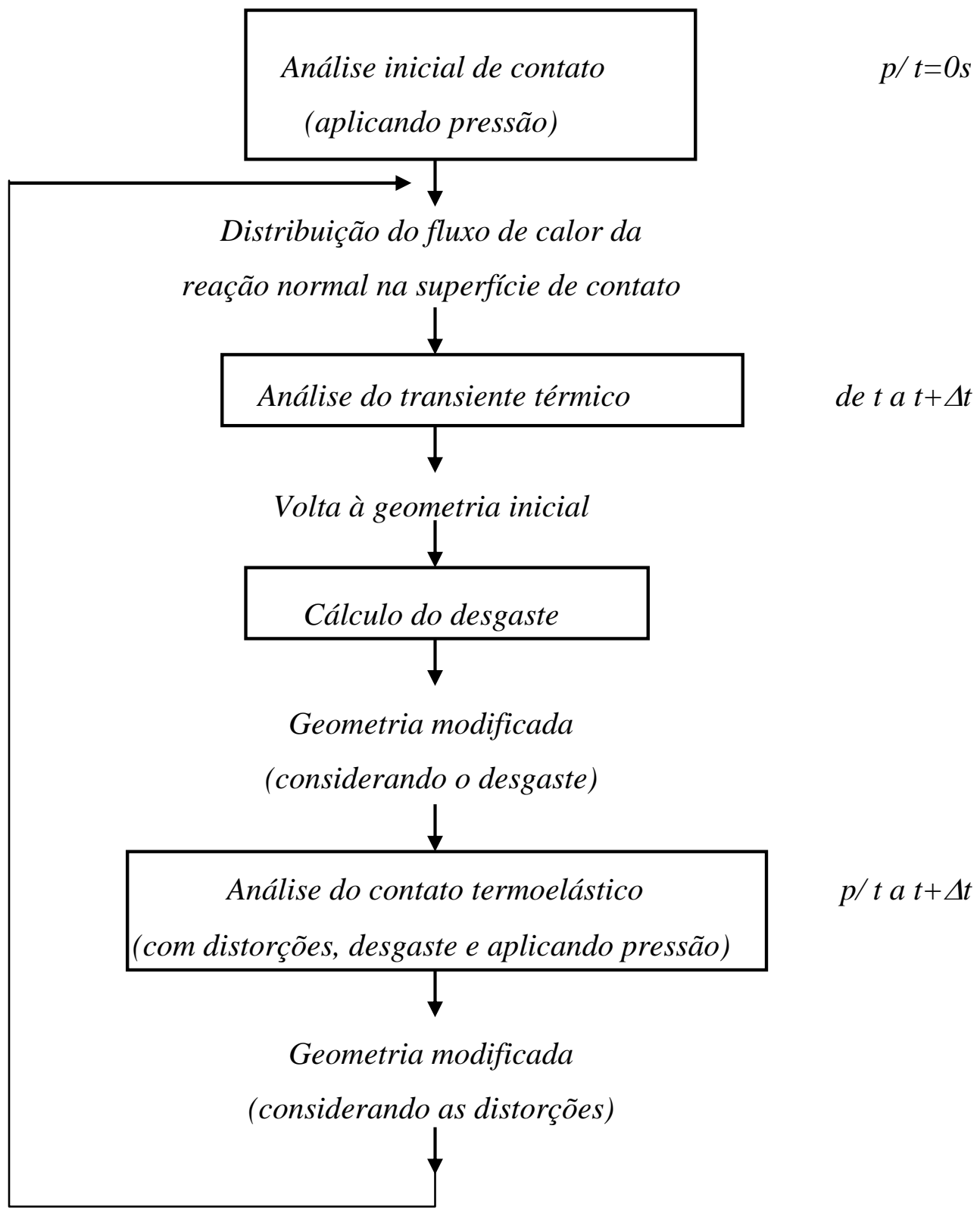

Figura 10 - Algoritmo termomecânico - BENSEDDIQ, WEICHERT, SEIDERMANN \& MINET (1996)

LIMPERT (1992) apresenta metodologias que permitem o cálculo das forças de frenagem, bem como a análise térmica do sistema de freios, visto que mostra formulações consistentes para o cálculo das temperaturas de frenagem considerando diferentes condições de frenagem, como descida de serra e repetidas frenagens, além 
de considerar os efeitos de resfriamento por convecção e radiação. A Figura 11 ilustra a metodologia e as variáveis abordadas.

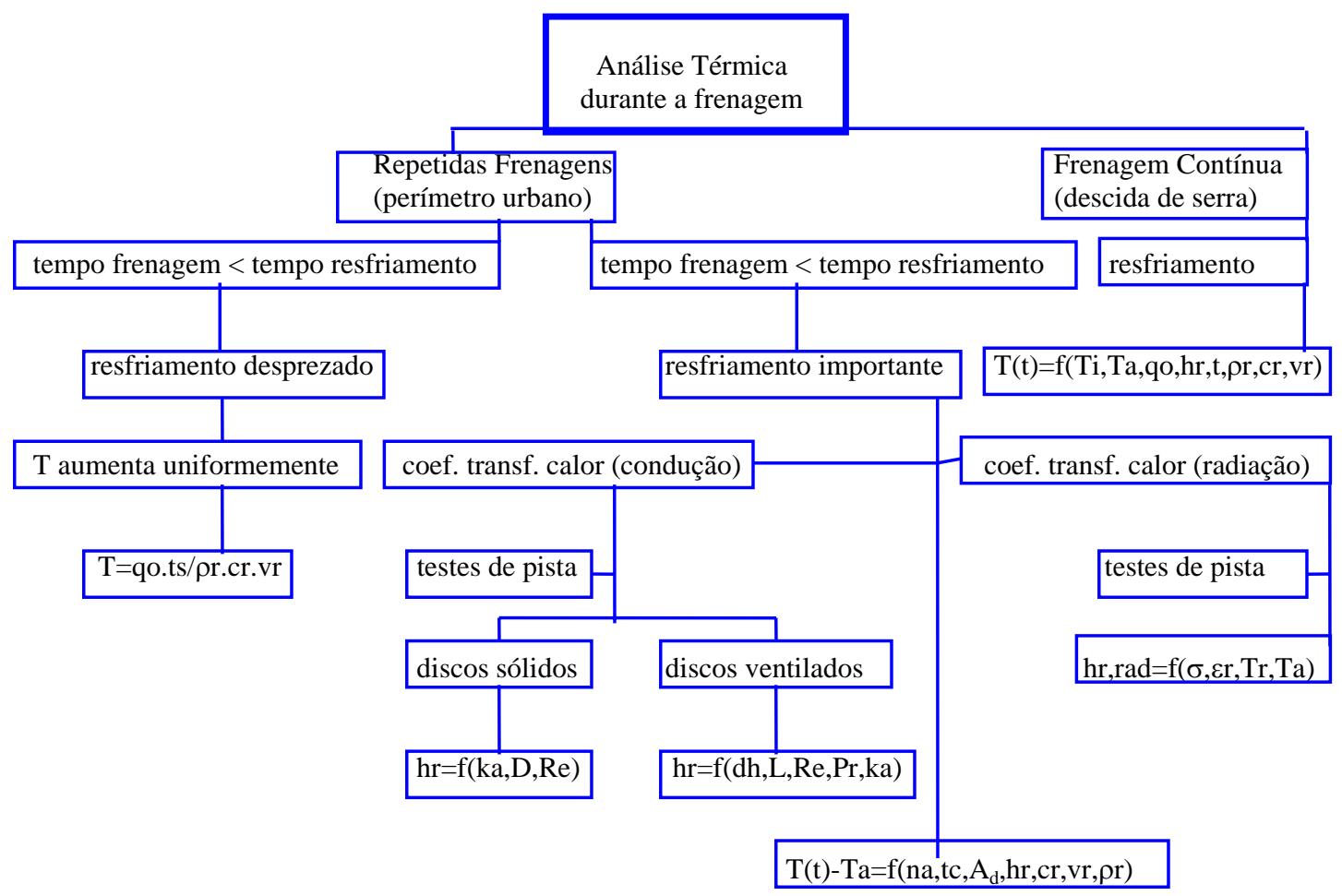

Figura 11 - Modelagem térmica do sistema de freios - LIMPERT (1992)

Uma modelagem anisotérmica aplicada a um sistema de freios a disco foi desenvolvida por EL ABDI \& SAMROUT (1999), que em seu estudo consideraram sete diferentes coeficientes de transferência de calor, obtidos através de testes. Descreveram a equação de equilíbrio térmico como uma equação diferencial e através de técnicas numéricas transformaram-na em uma equação matricial adequada para a análise usando o método dos elementos finitos.

Na equação matricial foram considerados, entre outros, os seguintes aspectos: calor específico, condutividade térmica, contribuição da convecção e condução, temperaturas e tempo. No entanto, os efeitos da radiação térmica foram desprezados. 


\section{METODOLOGIA}

\subsection{INTRODUÇÃO}

O calor gerado pelo contato entre a face do disco e o material de fricção em uma frenagem não é sempre uniformemente distribuído sobre a superfície do disco, mas depende da pressão local sobre ele.

A distribuição do calor de fricção gerado na interface disco/pastilha além de dependente da distribuição de pressão nesta interface, também é afetada pelo desgaste do material e pela expansão térmica, como destacam DAY \& NEWCOMB (1984).

Nos freios a disco a expansão do rotor (disco) ocorre em relação à pastilha de freio, tornando a expansão térmica de pouca importância. Já nos freios a tambor, a mudança na folga entre lona e tambor contribui para alterações térmicas, reduzindo o torque quando o tambor expande (aquecimento) e aumentando o torque quando o tambor contrai (resfriamento).

A força de fricção entre dois corpos em contato de escorregamento é primariamente gerada pela iteração física. Em uma escala microscópica, a aspereza da superfície aliada ao trabalho realizado produz energia térmica na camada superficial do par de fricção.

O transiente resultante na mudança de temperatura afeta as condições físicas da superfície de contato, que junto às mudanças químicas no material de fricção ajudam a explicar o fato da temperatura dos freios ser dependente do desgaste e da fricção. 
A interface de contato disco/pastilha, a distribuição de pressão e os efeitos localizados do desgaste do material e da expansão térmica invariavelmente conduzem à geração de calor não uniforme e como esses aspectos são interdependentes no processo de fricção na frenagem, torna-se necessário estimá-los corretamente para que um completo tratamento do problema térmico seja feito.

A fim de atacar o problema da distribuição das forças de contato entre pastilha e disco, HOHMANN, SCHIFFNER, OERTER \& REESE (1999) desenvolveram um modelo em elementos finitos que consiste do disco, caliper e duas pastilhas de freio. O modelo físico foi gerado usando elementos geométricos e a área foi mapeada em uma malha. Como resultado avaliaram a deformação, distribuição de tensões, pressão de contato e as regiões que momentaneamente deixavam a condição de fixação e tornavam-se deslizantes no contato.

Também a formação de produtos de degradação térmica na interface disco/pastilha pode modificar o desempenho friccional, como concluíram DAY \& NEWCOMB (1984).

Observaram ainda que altas temperaturas e grandes desgastes ocorrem sobre as regiões da interface onde há altas pressões.

Sob condições dinâmicas da frenagem, a pressão na interface raramente é uniforme e varia com o tempo, sendo continuamente modificada pela combinação de:

- tensões térmicas originadas da geração de calor friccional;

- tensões mecânicas originadas das forças aplicadas;

- desgaste do material.

Estes efeitos podem provocar perdas localizadas de contato na interface para algum estágio durante a frenagem com o conseqüente aumento das pressões e da razão de trabalho sobre as regiões remanescentes de contato.

A despeito das diferenças geométricas de projeto, ambos os tipos de freio (tambor e disco) usam o mesmo princípio para gerar força de frenagem: sapatas fixas são pressionadas contra um corpo rotacionando.

Forças normais são geradas pela pressão que empurra as pastilhas contra o disco. Uma reação aparece no local onde o caliper transfere a força para a pastilha no 
outro lado do disco. Desta forma, a força normal (N) em cada pastilha pode ser calculada pela Eq. 2.

$$
\mathrm{N}=\mathrm{p} \cdot \mathrm{A}_{\mathrm{P}}
$$

A força tangencial (R) gerada na superfície de fricção resulta na força de friç̧ão em cada lado do disco, calculada na Eq. 3.

$$
\mathrm{R}=\mu \cdot \mathrm{N}
$$

Com as forças de fricção agindo em ambos os lados do disco, pode-se calcular o fator de freio ( $\left.\mathrm{c}^{*}\right)$. Partindo da definição de que fator de freio é a razão entre a força de frenagem produzida no contato entre pastilhas e disco e a força aplicada para comprimir as pastilhas contra o disco, tem-se a Eq. 4.

$$
\mathrm{C}^{*}=2 \mathrm{R} / \mathrm{N}
$$

Substituindo (3) em (4), tem-se o valor do fator de freio para freios a disco.

$$
\mathrm{C}^{*}=2(\mu . \mathrm{N}) / \mathrm{N}=2 \mu
$$

Este resultado parece indicar que o fator de freio é um valor constante em freios a disco, dependendo unicamente do coeficiente de fricção do material utilizado. No entanto, é importante relembrar que alguns fatores podem influenciar e alterar tal coeficiente durante o processo de frenagem, dentre os quais destaca-se a temperatura. 


\subsection{CONDIÇÕES DE CONTORNO}

Conforme FERNANDES, ADAS, HAGE \& CANALE (2000), o fenômeno da frenagem é bastante complexo, pois envolve relações entre sistemas complexos cuja modelagem física e matemática nem sempre pode ser desenvolvida facilmente. Entre elas tem-se: as reações do motorista, do veículo e do sistema de freios, o contato entre pneumático e pavimento e a transformação de energia cinética e potencial em energia acústica e térmica durante a frenagem, além dos aspectos humanos, ambientais, legais veiculares e operacionais relacionados com o desempenho, a estabilidade e a segurança veicular.

A acuracidade de qualquer modelo térmico é primariamente dependente de quão cuidadosamente as condições de contorno para entrada e saída de energia são especificadas e a acuracidade com que o calor específico do material (para a energia armazenada) e a condutividade térmica do material (para o transporte de energia) são conhecidos, destacam SHERIDAN, KUTCHEY \& SAMIE (1988).

Na realidade, as condições de contorno, em contínua evolução com a velocidade do veículo, dependem do meio ambiente circundante e da geometria da roda e por isso não podem ser consideradas constantes.

As condições de contorno que definem a razão pela qual a energia térmica é transferida do disco para o ambiente consistem do coeficiente de transferência de calor por convecção e da emissividade da radiação. Já para as superfícies adjacentes, o disco pode transferir calor tanto por condução como por radiação térmica.

A variação de energia determina a variação de temperatura de um corpo. Desta forma, a temperatura de um corpo depende da temperatura ambiente, do material que constitui o corpo e das condições de energia final e inicial. Muitas são as condições que influenciam a temperatura durante a frenagem, mas de um modo geral, é possível classificá-las, segundo CANALE, IOMBRILLER, ADAS \& ANDRADE (1999), em cinco grandes grupos:

$\Rightarrow$ condições de frenagem;

$\Rightarrow$ características do veículo;

$\Rightarrow$ especificações do disco; 
$\Rightarrow$ especificações da pastilha;

$\Rightarrow$ condições ambientes.

Através da Figura 12, é possível observar as variáveis envolvidas em cada um destes aspectos que mais influenciam na temperatura.

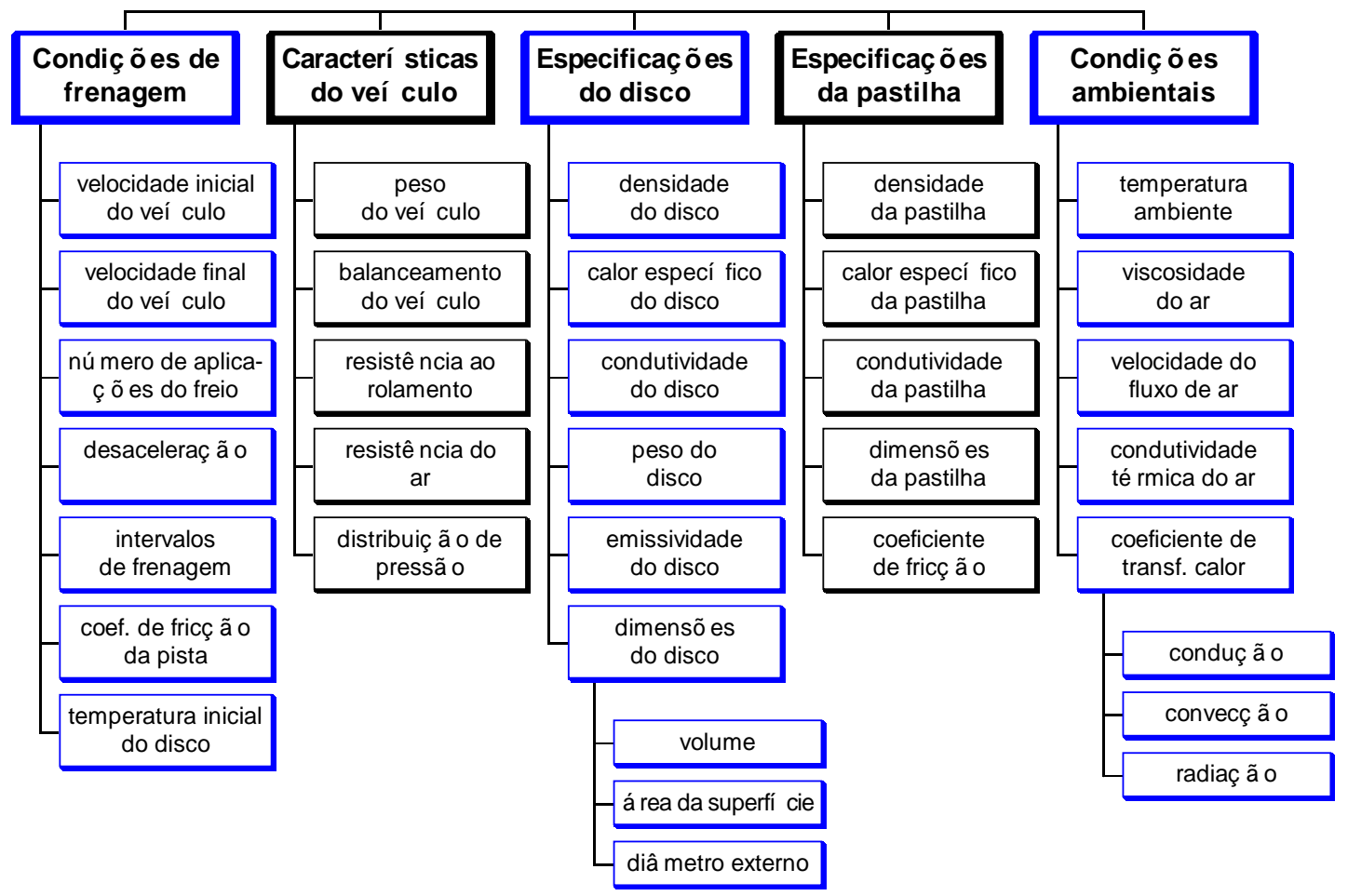

Figura 12 -. Variáveis envolvidas nas condições que influenciam a temperatura na frenagem - CANALE, IOMBRILLER, ADAS \& ANDRADE (1999)

\subsection{MODELO}

SHERIDAN, KUTCHEY \& SAMIE (1988) salientam que qualquer modelo térmico tem certas limitações, mas todos podem ser ferramentas úteis quando o impacto de alguma suposição feita (respeitando particularmente as condições de contorno e propriedades do material) é bem compreendido. 
Quando se aplica numa frenagem, um torque constante atuando em cada pastilha, produz-se uma desaceleração constante no disco, então a razão de geração de calor nas superfícies de fricção tende a diminuir linearmente com o tempo.

Se as pastilhas de freio não cobrem a área total do disco, a razão de geração de calor não é uniforme na direção circunferencial ao longo do disco.

Entretanto, na prática, como afirma NEWCOMB (1960), a razão de rotação é tão alta que é possível assumir-se que a razão efetiva de geração de calor para algum ponto é a média para o disco todo, exceto próximo ao final da aplicação, quando a razão da dissipação de energia é muito pequena em algumas situações. Desta forma, o gradiente circunferencial de temperatura pode ser negligenciado sem apresentar um erro considerável.

Para pastilhas de material convencional, o calor gerado pode ser assumido fluindo totalmente para o disco de freio, o que a pastilha absorve é desprezível, exceto em aplicações de freio muito longas.

Salienta ainda NEWCOMB (1960) que a espessura do disco deve ser considerada na variação de temperatura, pois foi observado que quanto menor a espessura do disco, maior será a temperatura na superfície.

O projeto do sistema de freio e seu modo de utilização influenciam sua capacidade de resfriamento. Muitas vezes usa-se a temperatura como medida de quão adequada é a capacidade de resfriamento do freio. No entanto, como destaca LIMPERT (1975), a temperatura é uma variável dependente, isto é, ela é função da geometria do freio, da forma de frenagem, do fluxo de ar que circunda o freio e das propriedades térmicas dos materiais envolvidos no processo de dissipação de calor, assim é preciso cautela na avaliação da capacidade de resfriamento do sistema de freios, considerando-se todos os demais fatores que afetam sua temperatura.

No levantamento bibliográfico realizado neste trabalho foi possível observar os aspectos térmicos da frenagem, bem como diferentes metodologias utilizadas para analisar o desempenho do sistema de freios.

No entanto, nota-se que este trabalho traz uma contribuição original para a análise do desempenho na frenagem de veículos pesados considerando a influência do aquecimento do sistema de freios, em particular, avaliando a variação do fator de freio no processo de frenagem. 
No desenvolvimento deste trabalho foi de fundamental importância o resultado dos testes em perímetro urbano, onde sob condições críticas de seguidas frenagens e precário resfriamento, foram obtidos elevados valores de temperaturas de estabilização. Através dos diferentes pontos instrumentados foi possível definir os pontos mais críticos de aquecimento, principalmente no par de fricção.

A partir destes dados do trecho urbano foi elaborado um procedimento de teste de pista, a fim de atingir os mesmos níveis de temperatura. Durante os testes de pista foram ainda consideradas diversas variações tanto na ventilação como na carga do veículo.

Paralelamente foram realizados testes em dinamômetro inercial para obter a curva do fator de freio do sistema de freios estudado, em relação à temperatura.

\subsubsection{TRANSMISSÃO DE CALOR}

No sistema de freios no momento da frenagem, praticamente toda energia cinética do veículo é transformada em energia térmica, através do atrito entre disco e pastilha.

Tal energia térmica será distribuída no sistema dependendo de como ocorre o processo de frenagem, que poderá ser:

- frenagem de emergência - quando o sistema de freio é acionado proporcionando uma frenagem total e rápida.

- frenagens repetidas - quando o sistema de freios é repetidamente acionado em intervalos, como o que ocorre em perímetro urbano.

- frenagem em descida de serra - quando o sistema de freios é acionado durante um longo período para controle de velocidades em declive.

A frenagem de emergência é caracterizada por alta desaceleração e como ocorre em um curto espaço de tempo, é possível considerar-se toda a energia sendo absorvida pelo disco. Será pequeno o efeito de condução para os componentes próximos, assim como a convecção e a radiação, conforme mostra IOMBRILLER (1997). 
Através da Figura 13, é possível observar-se o comportamento qualitativo da temperatura em uma frenagem de emergência.

Já nos casos de frenagens repetidas e em descida de serra a dissipação do calor gerado é muito importante, evitando que temperaturas muito elevadas sejam atingidas.

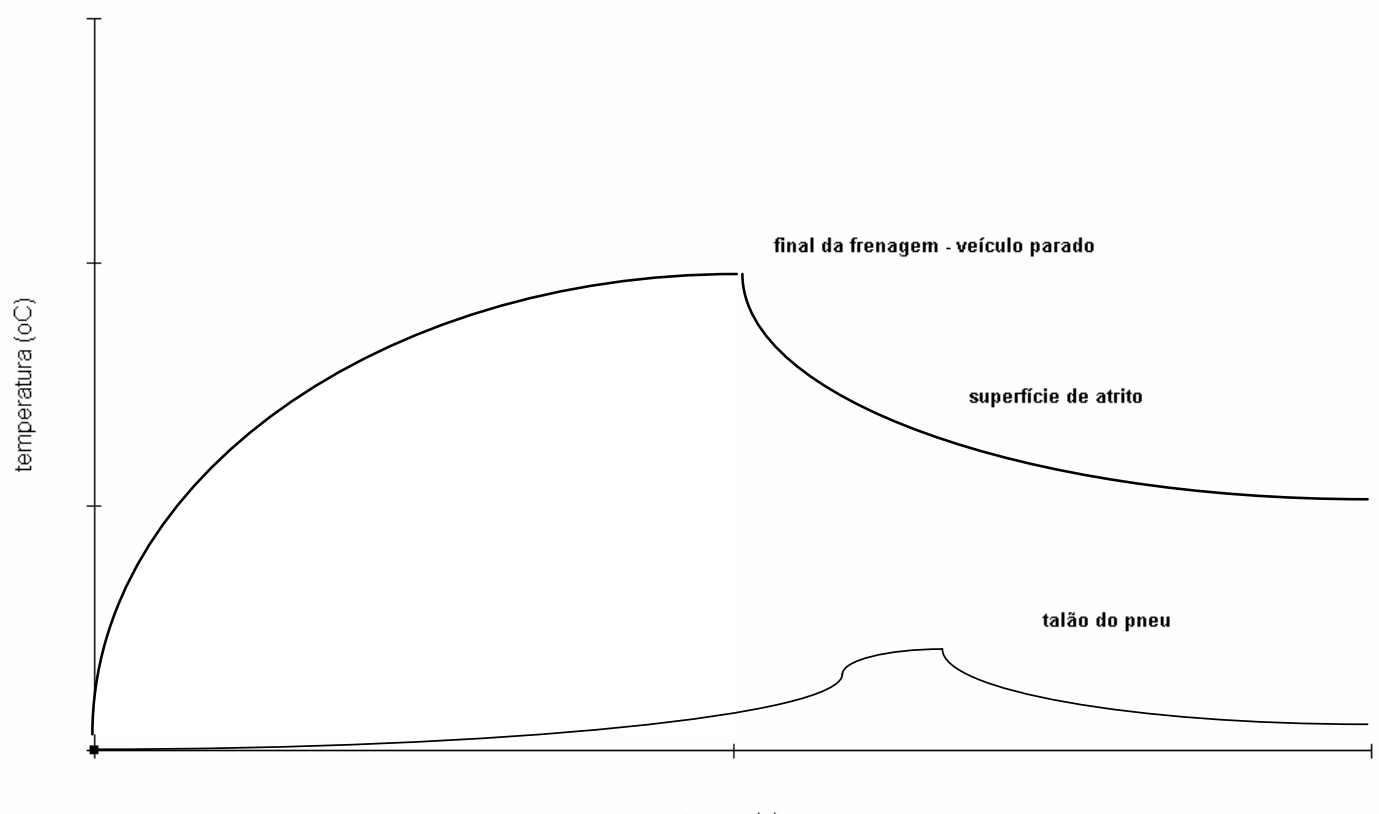

Figura 13 - Frenagem de emergência - Comparativo qualitativo da variação de temperatura - RITZ, ADAS \& FRANCISCO (1995)

Quando ocorrem repetidas frenagens, a temperatura do disco aumenta rápida ou lentamente, dependendo principalmente da velocidade e desaceleração na frenagem e atinge uma temperatura de equilíbrio, chamada de temperatura de estabilização, como mostra a Figura 14.

A frenagem em descida de serra é caracterizada por velocidade geralmente constante e aceleração nula. Do aspecto térmico, RITZ, ADAS \& FRANCISCO (1995) definem que o tempo pode ser tomado como infinito, aquecendo-se o freio uniformemente, a temperatura estabiliza-se e continua constante, como ilustra a Figura 15. 
Tf-To

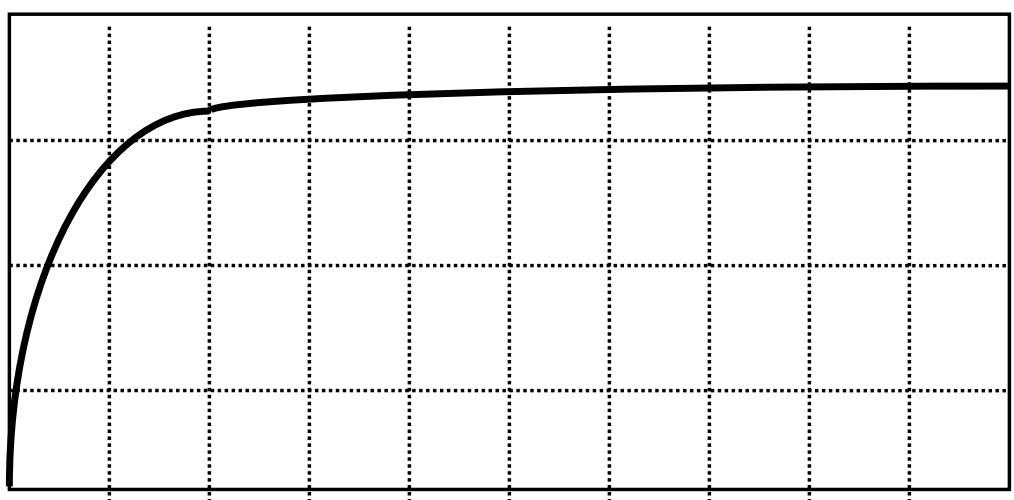

número de aplicações

Figura 14 - Variação da temperatura do disco ao final de uma frenagem com várias aplicações do freio - NEWCOMB (1960)

Temperatura $\left({ }^{\circ} \mathrm{C}\right)$

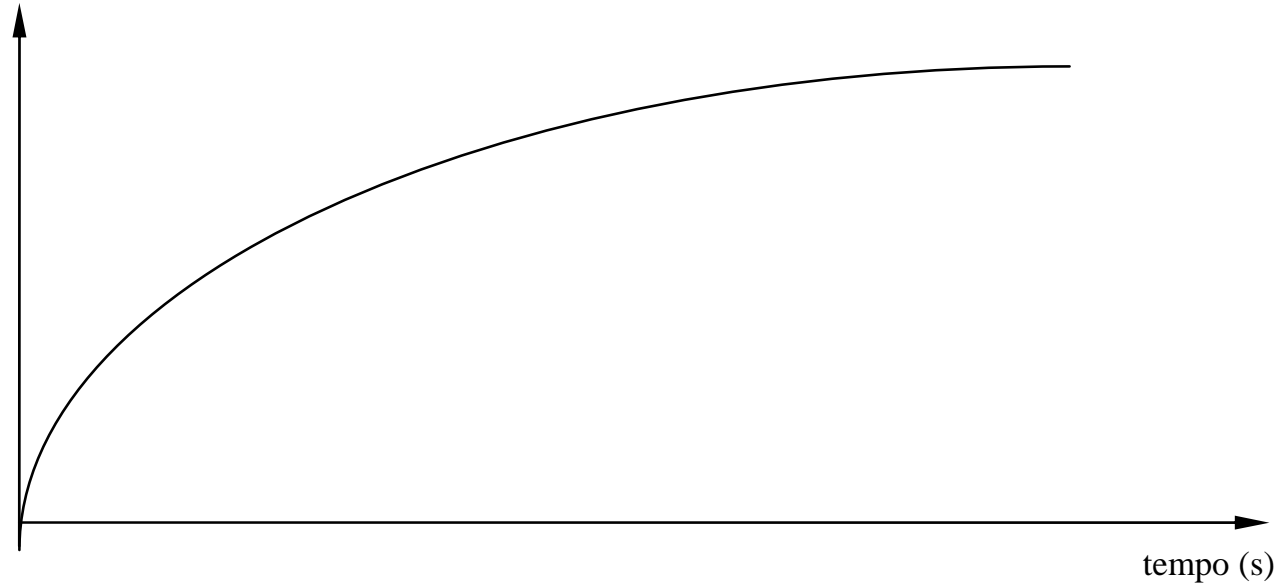

Figura 15 - Frenagem contínua - Comparativo qualitativo da variação da temperatura - RITZ, ADAS \& FRANCISCO (1995)

A aplicação de cargas no disco de freio é complexa. Ele está sujeito a frenagens de emergência, frenagens longas ou repetidas frenagens. Durante um percurso, o disco de freio pode ser submetido a todos estes tipos de frenagem, geralmente com uma freqüência variável. Desta forma a definição de um ciclo médio 
não é fácil de ser estabelecida. No entanto, a fim de possibilitar o estudo térmico e dinâmico do processo de frenagem, torna-se necessário a definição de um tipo específico de frenagem.

ROWSON (1978) chama a atenção do fato de que durante a aplicação de uma frenagem, o calor é gerado continuamente, mas diminui linearmente com o tempo, e sugere que o valor instantâneo de calor seja calculado conforme a Eq. 5.

$$
\text { qi }\left(t^{\prime}\right)=q\left(1-t^{\prime} / t s\right)
$$

A energia térmica (calor) produzida durante a frenagem é inicialmente armazenada pela capacidade térmica do material da superfície de contato do disco e depois vai para as regiões de menor temperatura, e simultaneamente é transferida para o ambiente, com uma constante de tempo que depende das distâncias entre os componentes do sistema de freios e das propriedades térmicas dos materiais que os constituem.

Embora a transmissão de calor seja um efeito combinado de condução, convecção e radiação. No processo de frenagem é possível avaliar-se a importância de cada um deles.

LIMPERT (1975) destaca que a contribuição de cada modo de transferência de calor varia com a temperatura atingida no freio, a forma de frenagem e os parâmetros de carga térmica específicos.

A condução de calor ocorre através de um sólido, como mostra KERN (1982). O mecanismo consiste de uma transmissão de energia através de um corpo cujas moléculas, exceto vibrações, permaneçam sempre em posições fixas. No sistema de freios é possível observar-se o fenômeno de condução transmitindo calor do disco de freio principalmente para o cubo de roda.

Além da geometria, e das diferenças de temperaturas, a condução de calor é diretamente proporcional ao coeficiente de condutividade térmica, propriedade do material.

Na convecção o calor é inicialmente absorvido de uma fonte pelas partículas do fluido imediatamente adjacentes a ela e é então transferido para o interior do fluido, misturando-se com ele. 
A quantidade de calor transferido por convecção é diretamente proporcional às temperaturas e às dimensões, mas depende também de um coeficiente de transferência de calor.

O coeficiente de transferência de calor por convecção depende da velocidade do ar, da sua direção e da temperatura do corpo considerado. Também depende da geometria do projeto do disco (sólido, ventilado, com aletas). Este coeficiente pode ser diferente para pontos distintos da mesma superfície e ainda variar em função do tempo.

Tal coeficiente é de difícil definição já que depende de características que se alteram constantemente, como o comportamento do ar e o número de Reynolds, Nusselt e Prandtl, entre outras.

Segundo SARTORI (1972), o efeito da turbulência produzido por irregularidades pode aumentar a troca térmica por convecção em até 50\%. Já a presença de aletas pode aumentar a transferência de calor por convecção forçada em até 5 vezes em relação à superfície lisa.

Tanto a condução quanto a convecção de calor necessitam da presença de um meio para conduzir o calor de uma fonte para um receptor. Entretanto, a transmissão de calor por radiação não necessita de um meio intermediário, e o calor pode ser transmitido até mesmo através do vácuo absoluto.

A radiação térmica é fortemente influenciada pela temperatura, pois é diretamente proporcional à sua quarta potência. Também depende das dimensões dos corpos envolvidos e de dois outros fatores: a emissividade e o fator de forma geométrico.

Emissividade, segundo KERN (1982), é a razão entre a potência emissiva verdadeira e a potência emissiva de um corpo negro sob temperatura idêntica. Uma vez que ela é tomada como referência, a emissividade de um corpo negro é igual a um.

As emissividades dos materiais comuns cobrem um grande intervalo de valores e muitas já se encontram tabeladas. A emissividade depende do acabamento ou polimento da superfície e pode variar com a temperatura. Superfícies altamente polidas e brancas geralmente possuem menores valores do que superfícies negras. 
O fator de forma geométrico, ou fator de configuração, relaciona a posição e a forma geométrica das áreas consideradas. Em alguns casos é possível encontrar-se gráficos de formas padronizadas, obtidos experimentalmente, ou se for necessário faz-se o cálculo aproximado.

No processo de frenagem quando altas temperaturas são atingidas (acima de $400^{\circ} \mathrm{C}$ ) observa-se o aquecimento de rodas e pneus devido ao fenômeno de radiação térmica. Desta forma, no projeto de um sistema de freios, a radiação de calor deve ainda ser limitada pelas temperaturas máximas admissíveis nos pneus.

Experimentos realizados por LIMPERT (1975) mostraram que em frenagens normais, a transferência de calor do disco por radiação contribui em menos de 5\%. No entanto, em altas temperaturas pode chegar a ser responsável por $1 / 3$ do resfriamento.

No entanto, durante a frenagem, nem toda a energia cinética do veículo transforma-se em energia térmica pela fricção entre a pastilha e o disco. As perdas que ocorrem são, em parte, devido às forças de resistência do ar, resistência ao rolamento dos pneus e pela fricção das partes rotativas do sistema de transmissão.

Uma forma prática de prever e estimar as perdas pela dissipação de energia através do arrasto aerodinâmico, da resistência ao rolamento e pelo escorregamento da roda é analisando-se o desempenho de um veículo protótipo.

No entanto, CASSETARI (1998) em seu trabalho de investigação da resistência friccional concluiu que em aerodinâmica de veículos terrestres, a parcela devido à fricção pode ser desprezada, sem que erros significativos ocorram.

\subsubsection{CÁLCULO TÉRMICO}

A energia cinética do veículo (E) pode ser calculada considerando-se o efeito das partes rotativas, a massa do veículo e sua velocidade, como mostra a Eq. 6.

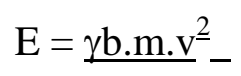


É importante considerar que esta é a energia cinética total do veículo, que deverá ser dividida pelo número de discos de freio presentes no veículo para que esta energia seja equivalente à energia térmica dissipada na frenagem em cada roda (descontadas as perdas), a qual será dissipada por radiação, condução e convecção.

A pastilha inteira é considerada em contato com o disco durante a frenagem e a superfície de contato corresponde à superfície de fricção da pastilha. Por causa da alta velocidade de rotação do disco, o calor é assumido sendo uniformemente gerado no anel de contato.

Esta consideração significa que o gradiente circunferencial de temperaturas é negligenciado, especialmente entre o início e o final do contato da pastilha.

A quantidade de calor dissipada por radiação ocorre principalmente do disco para as rodas e para o ambiente e pode aproximadamente ser calculada da seguinte forma, pela Eq. 7.

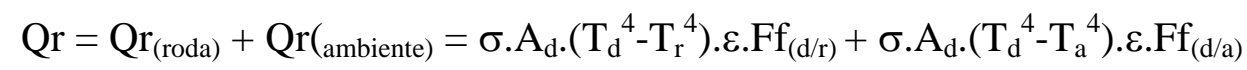

O valor de emissividade pode ser obtido em tabelas de valores médios para diversos materiais, como as encontradas em HOLMAN (1983).

O fator de forma pode ser obtido considerando-se as formas do disco e da roda como dois cilindros concêntricos, para os quais há relações definidas em HOLMAN (1983). Entretanto, estes valores correspondem ao corpo externo emitindo para o interno, para que possamos obter o valor do disco emitindo para a roda é necessário usar a relação de reciprocidade, expressa na Eq. 8.

$$
A_{r} \cdot F f_{r}=A_{d} \cdot F f_{d}
$$

Já o fator de forma do disco emitindo para o ambiente, pode ser considerado unitário, considerando-se todo o ambiente ao redor do disco.

A quantidade de calor transferido por condução, considerando-se o disco e o cubo de roda, pode ser assim calculada pela Eq. 9. 


$$
\begin{aligned}
& \mathrm{QC}_{\mathrm{c}}=\underline{\mathrm{k}}_{\mathrm{d}} \cdot \mathrm{A}_{\underline{\mathrm{l}}} \cdot\left(\mathrm{T}_{\underline{\mathrm{c}}}-\underline{T}_{\mathrm{d}}\right) \\
& \mathrm{L}_{\mathrm{dc}}
\end{aligned}
$$

Para a maior parte dos cálculos realizados, a condutividade térmica utilizada pode ser obtida através de tabelas como indica KERN (1982).

Considerando que a energia cinética transforma-se em energia térmica, podemos considerar que a derivada da energia cinética no tempo será correspondente à somatória da quantidade de calor dissipado por radiação, condução e convecção, como na Eq. 10.

$$
\underline{\mathrm{dE}}=\mathrm{Qr}+\mathrm{Qc}+\mathrm{Qcv}
$$

dt

Substituindo os termos correspondentes, tem-se a Eq. 11:

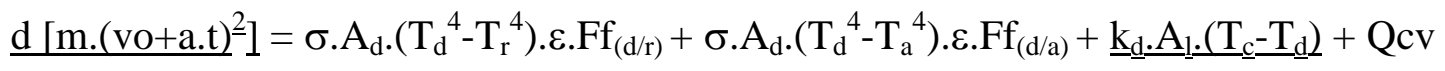
dt $\quad 2$

$\mathrm{L}$

Solucionando-se a equação diferencial, é possível obter a quantidade de calor transmitida por convecção (Qcv), a qual pode ser descrita da forma indicada na Eq. 12.

$$
\text { Qcv }=h \cdot A_{d} \cdot\left(T_{d}-T_{a}\right)
$$

Considerando-se o valor correspondente para a temperatura ambiente, é possível calcular-se o coeficiente de transferência de calor por convecção.

Para avaliar este fenômeno sem estudar profundamente o complexo problema fluido-mecânico, o coeficiente de transferência de calor por convecção é geralmente considerado uniforme no disco.

No entanto, é importante ressaltar que a equação diferencial (11) é normalmente resolvida de forma discreta, o que leva, para sistemas complexos como 
o estudado neste caso, a modelos com muitos graus de liberdade, o que demanda programas especializados (elementos finitos, elementos de contorno, diferenças finitas, etc.), recursos computacionais caros, com computadores rápidos e com grande capacidade de manusear dados, mão-de-obra qualificada e treinada, uma grande quantidade de dados e parâmetros para representar adequadamente e discretamente o sistema. Tudo isto resulta em análises que demandam um grande tempo para aplicação industrial e elevados custos de desenvolvimento.

De maneira geral, para a solução da Eq. 11 são necessários valores empíricos obtidos de testes. Ou seja, não é possível encontrar valores objetivos de temperatura, quantidade de calor ou coeficiente de transferência de calor independentes da realização de ensaios.

Observa-se na literatura científica que na modelagem térmica dos sistemas de freios, os coeficientes de transferência de calor são alterados para que o resultado do modelo matemático reflita os valores encontrados nos testes de pista. Os coeficientes de transferência de calor geralmente são calibrados, para que o modelo teórico dê resultados próximos aos observados na prática. Esta é uma solução acadêmica, mas não prática e industrial, já que é muito difícil se ter bons resultados na modelagem do sistema de freios, sem um protótipo e testes do veículo, o que limita seu uso de maneira intensiva em projetos.

Considerando estas dificuldades matemáticas e práticas, e observando o comportamento térmico do disco de freio durante os ensaios realizados, é possível concluir que a solução deste equacionamento é bastante útil durante o período transitório do percurso urbano, onde as temperaturas ainda estão em elevação. No entanto, quando o sistema entra em regime permanente, ou seja, quando são atingidas as temperaturas de estabilização, torna-se viável a análise das próximas frenagens como sendo frenagens de emergência, usando-se o ponto de estabilização como condições iniciais de contorno.

A partir destas considerações foi desenvolvido um programa computacional simulando o veículo freando em emergência a partir das condições de contorno iniciais para a temperatura de estabilização atingida. 


\subsubsection{PROGRAMA DE CÁLCULO PARA SIMULAÇÃO VEICULAR}

VON GLASNER, POVEL \& WUEST (1994) destacam que a simulação do desempenho veicular oferece a possibilidade de analisar o comportamento de um novo projeto de veículo, ou de novos sistemas a serem integrados, bem antes do estágio dos primeiros protótipos, o que reduz sensivelmente o tempo e os custos de desenvolvimento.

Sob esta mesma ótica, um programa de cálculo para simulação veicular foi desenvolvido durante este trabalho. De um modo geral, o esquema do programa segue o formato indicado no Apêndice 1.

As Figuras 16 e 17 mostram ainda alguns diagramas de blocos que fazem parte do programa computacional.

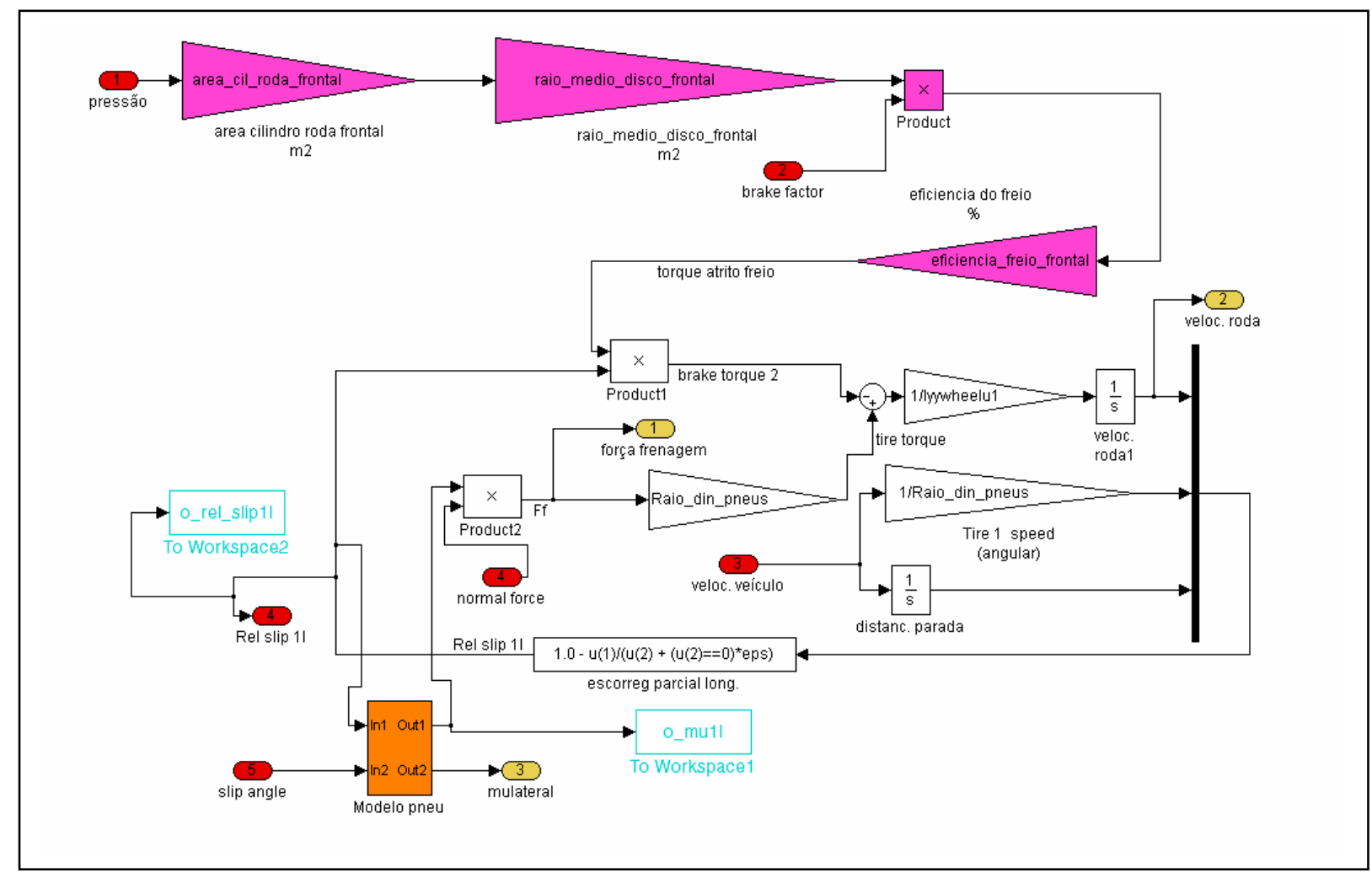

Figura 16 - Diagrama do programa computacional utilizado 


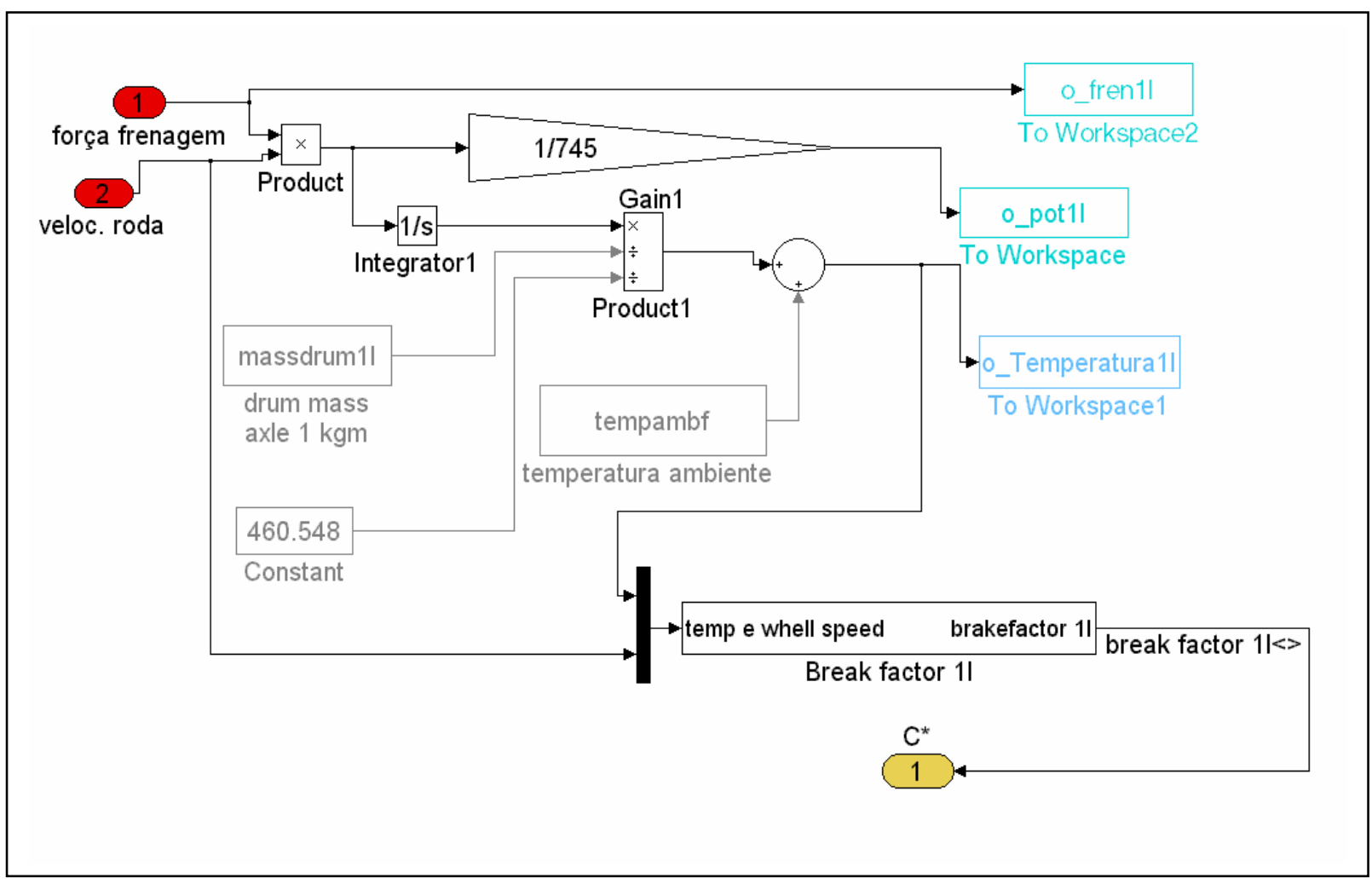

Figura 17 - Diagrama do programa computacional - cálculo da frenagem

A partir dos dados geométricos do sistema de freio em conjunto com a entrada de pressão aplicada é obtido o torque de frenagem, considerando os efeitos térmicos através da equação para o fator de freio em função da temperatura. Paralelamente, a partir das forças de frenagem em cada roda é obtido o torque real. A diferença entre estes torques é aplicada na inércia de cada roda, fornecendo a desaceleração da roda, que através de uma integração oferece a velocidade angular da roda.

Através da velocidade angular da roda e da velocidade angular do veículo é obtido o escorregamento relativo, que em conjunto com a força normal (calculada através do peso do veículo, distância entre eixos e posição do CG) e o conjunto roda/pneu fornece a força real de frenagem.

O sistema continua o mesmo processo com um $\Delta \mathrm{t}=0,001 \mathrm{~s}$, até o final da frenagem. 
SPERANZA NETO, SILVA \& MARTINEZ (1992) salientam que a simulação consiste na solução de um modelo matemático e na interpretação dos resultados obtidos. Um modelo é capaz de fornecer apenas as informações implícitas nas hipóteses estabelecidas para o seu desenvolvimento, e as respostas de um dado sistema sempre serão função das excitações e das condições iniciais impostas.

Assim, a primeira preocupação ao se simular um sistema, é a definição destas condições iniciais e excitações.

O programa computacional utilizado oferece uma grande gama de possibilidades considerando:

- diferentes geometrias de veículos de dois eixos;

- diferentes condições de carregamento do veículo (posição do CG);

- variações geométricas do sistema de freios (dimensões do disco, massa do disco);

- diversas condições de frenagem (variando as velocidades iniciais e finais, o coeficiente de escorregamento da pista, temperatura ambiente). 


\section{ENSAIOS}

\subsection{MAPEAMENTO TÉRMICO}

A fim de otimizar a realização de testes com os veículos em desenvolvimento, tornando estes testes mais rápidos e objetivos é necessário realizar ensaios em pista, mapeando o sistema de freios térmica e dinamicamente, localizando assim os pontos mais importantes de avaliação térmica.

Através dos ensaios em pista será possível obter os valores da temperatura em diferentes pontos do sistema de freios, variando com a velocidade, com a pressão e com o tempo. Ainda será possível observar-se os efeitos do ambiente e do trajeto padrão adotado, assim como do tipo de frenagem.

Com a finalidade de obter detalhadamente a variação de temperatura em diversos componentes do sistema de freio, um mapeamento completo foi feito através da instalação de termopares em 130 pontos.

Os componentes monitorados foram:

- pista do retentor

- pista dos rolamentos

- cubo da roda

- manga do eixo

- talão do pneu

- disco de freio

- pastilha de freio 
Tanto o disco como a pastilha, foram instrumentados em diversos pontos, buscando definir os pontos críticos.

\subsubsection{INSTRUMENTAÇÃO}

O veículo utilizado nos testes de pista foi um ônibus urbano protótipo de dois eixos, com carga total máxima (17.000 kg), equipado com sistema de freios a disco pneumático.

Primeiramente foram instrumentados os discos (Figura 18) e as pastilhas (Figura 19), os quais tiveram furos de 3mm, diâmetro este o mínimo necessário para introduzir o termopar e o máximo para não afetar a integridade estrutural dos componentes.

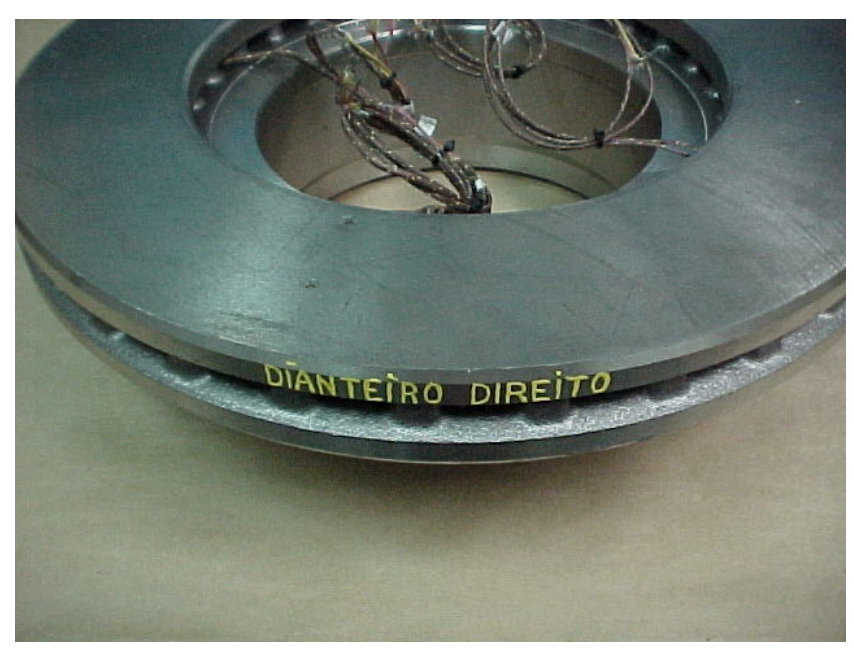

Figura 18 - Disco de freio instrumentado. 


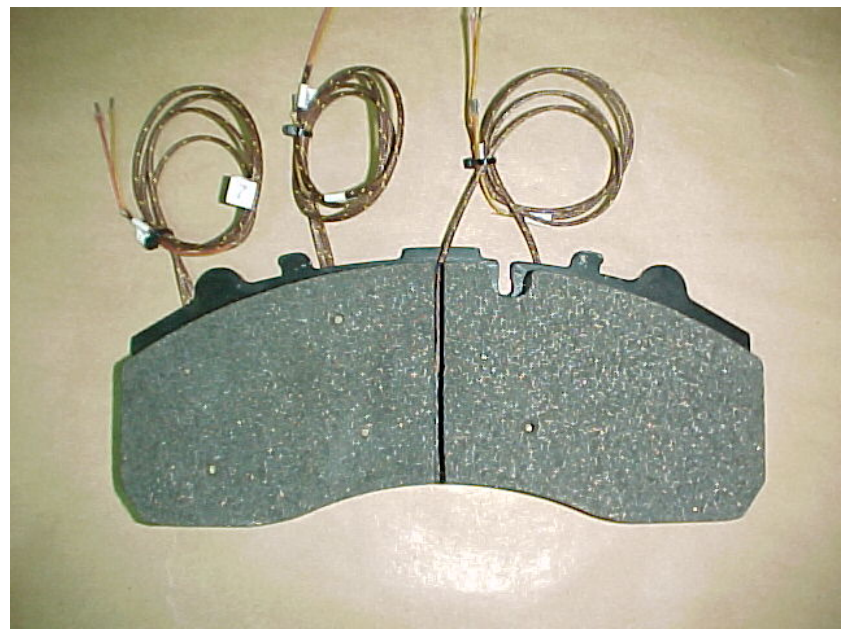

Figura 19 - Pastilha de freio instrumentada.

O termopar utilizado foi do tipo $\mathrm{K}$ (Cr-Al), conforme ilustra a Figura 20, com 3mm de diâmetro, que em ensaios anteriores tem demonstrado boa acuracidade nas medidas, com ponta seca (o que evita quebras e facilita a montagem no veículo) e isolado com fibra de vidro (oferece maior maleabilidade). Este tipo de termopar foi escolhido devido a sua grande faixa de trabalho, oferecendo uma maior margem de segurança, por ser este um trabalho de pesquisa onde valores extremos podem ser obtidos. Todos os termopares utilizados foram inspecionados e testados, conforme relatórios fornecidos pela DaimlerChrysler do Brasil. Um exemplo de tais relatórios está no Apêndice 2 deste trabalho.

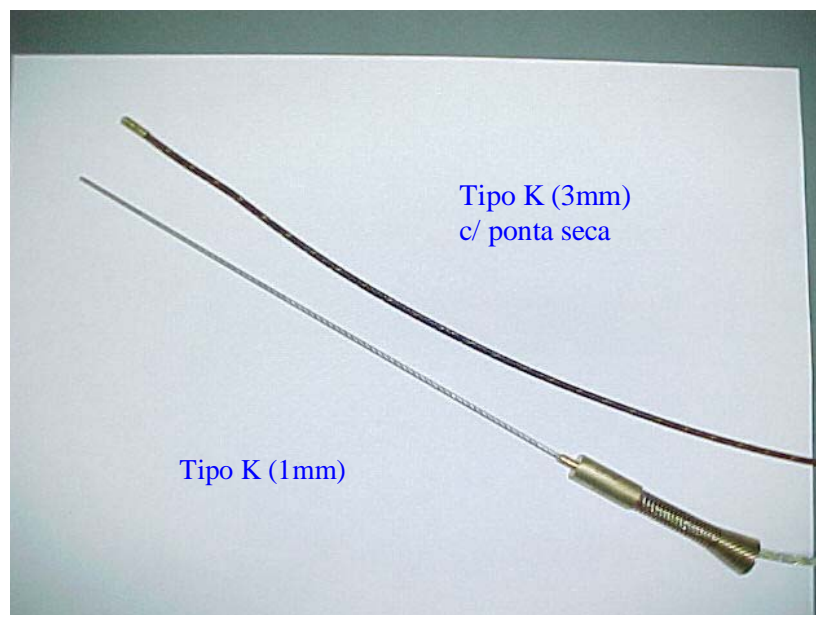

Figura 20 - Termopares utilizados 
Os cubos de roda (Figura 21), as pistas dos rolamentos, bem como as pistas do retentor, foram instrumentados com termopar do tipo K, com 1mm de diâmetro, com isolação mineral, garantindo segurança visto que o cubo trabalha na presença de graxa.

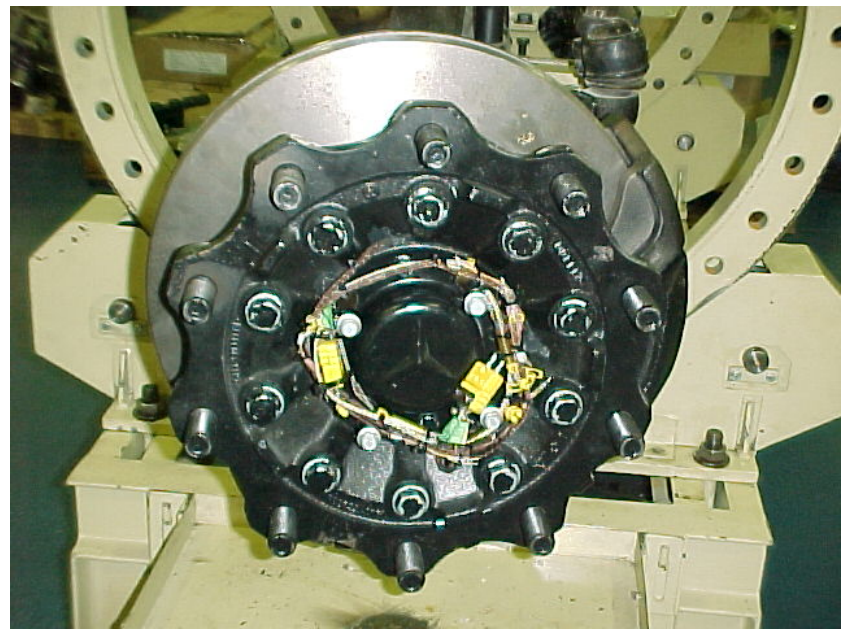

Figura 21 - Instrumentação do cubo de roda

A instrumentação dos pneus foi feita utilizando o mesmo tipo de termopar que os discos e as pastilhas, já que nesta região é fundamental que haja maleabilidade para evitar quebras. Os termopares foram instalados na roda, tendo contato com a borracha do talão do pneu.

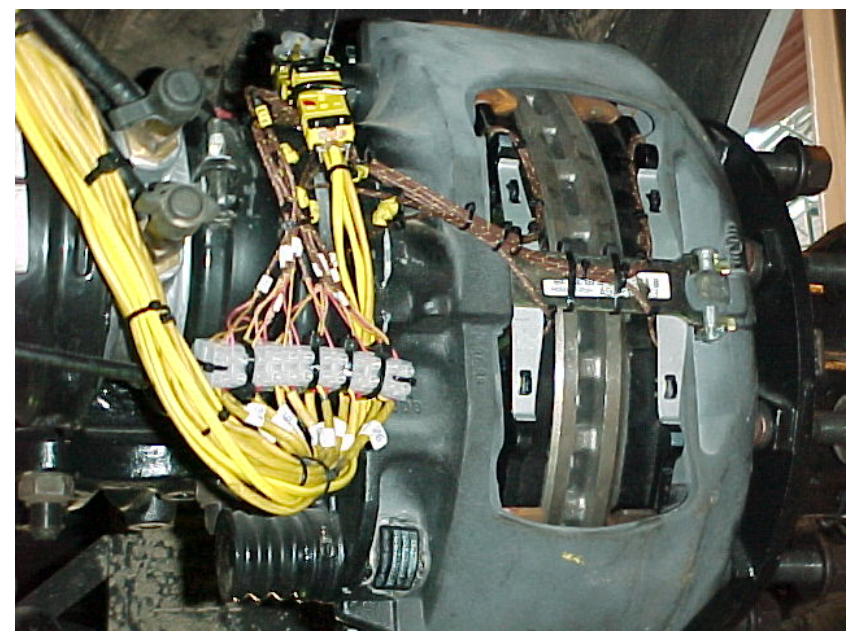

Figura 22 - Montagem do eixo instrumentado 
Os componentes instrumentados foram instalados no veículo (Figuras 22 e 23) e para que fossem ligados ao sistema de aquisição de dados, foram usados cabos de extensão do mesmo tipo que os termopares (tipo K), com medida de comprimento padrão para todos os pontos.

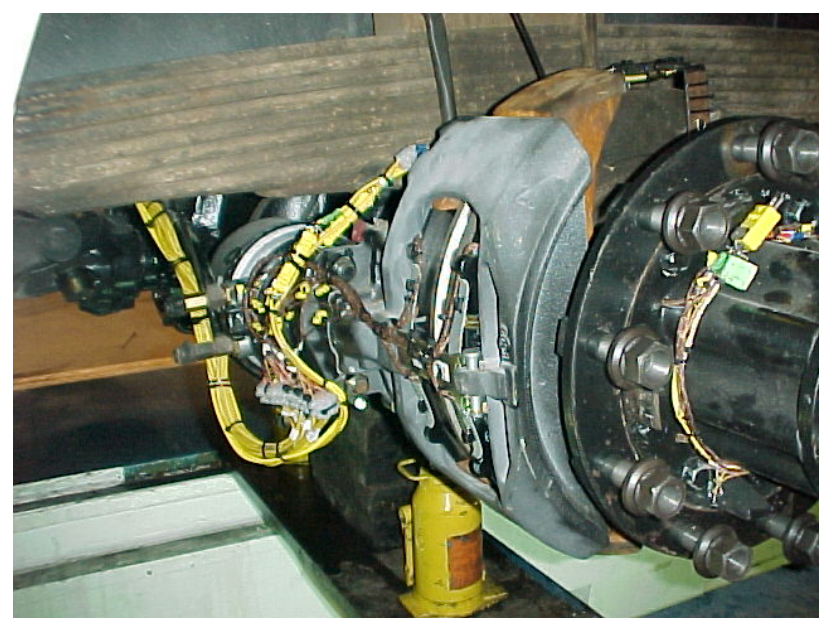

Figura 23 - Instalação do eixo instrumentado no veículo.

Os pontos rotativos (disco, cubo, pneu) têm suas medidas captadas por um coletor rotativo com 10 canais (Figura 24), que através de um sistema tipo escova transmite as medidas para o sistema de aquisição de dados.

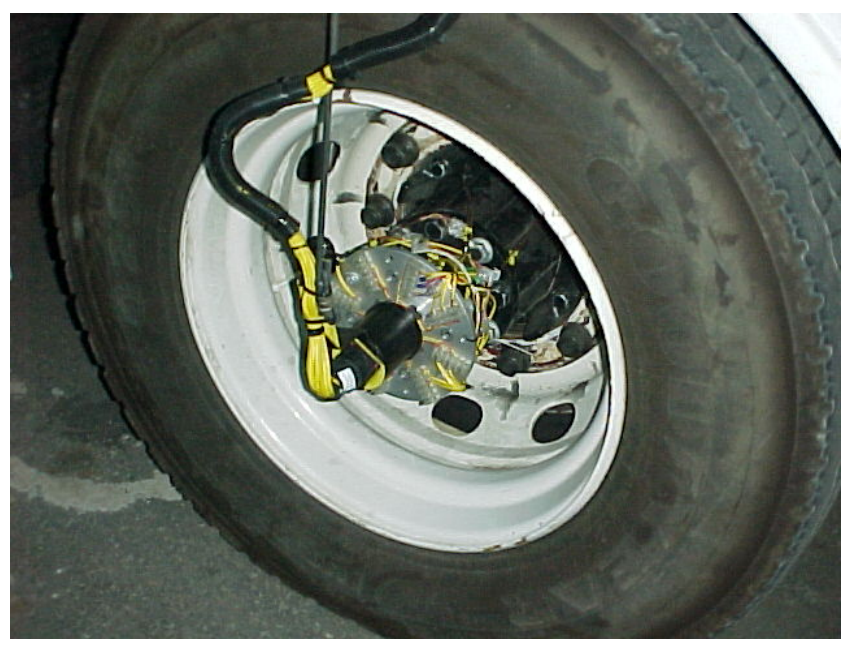

Figura 24 - Vista do coletor rotativo acoplado ao cubo da roda no veículo. 
O sistema de aquisição de dados (Figura 25) converte o sinal de um termopar para sinal digital para um computador da linha PC. O sistema completo consta de três partes. Inicialmente um pré-amplificador de sinal de termopar (da ordem de microvolt para volt), em seguida o sinal analógico em volt é transferido em sinal digital (12 bits) que por sua vez é lido por um microcomputador da linha PC (pentium 2 MMX 233MHz). Este sistema é um pacote comercial desenvolvido pela National em formato PXI (padrão internacional de computação industrial).

Todo esse processo é manipulado via software em linguagem Labview. O aplicativo foi desenvolvido pela FAC/USP/DaimlerChrysler.

Simultaneamente à aquisição dos dados térmicos, outro instrumento (Correvit) coletava os dados dinâmicos tais como velocidade do veículo, desaceleração média durante a frenagem, pressão de atuação do freio e espaço percorrido.

Após ter sido completada a montagem, o sistema de aquisição de dados foi calibrado com entradas padronizadas nos diversos sensores.

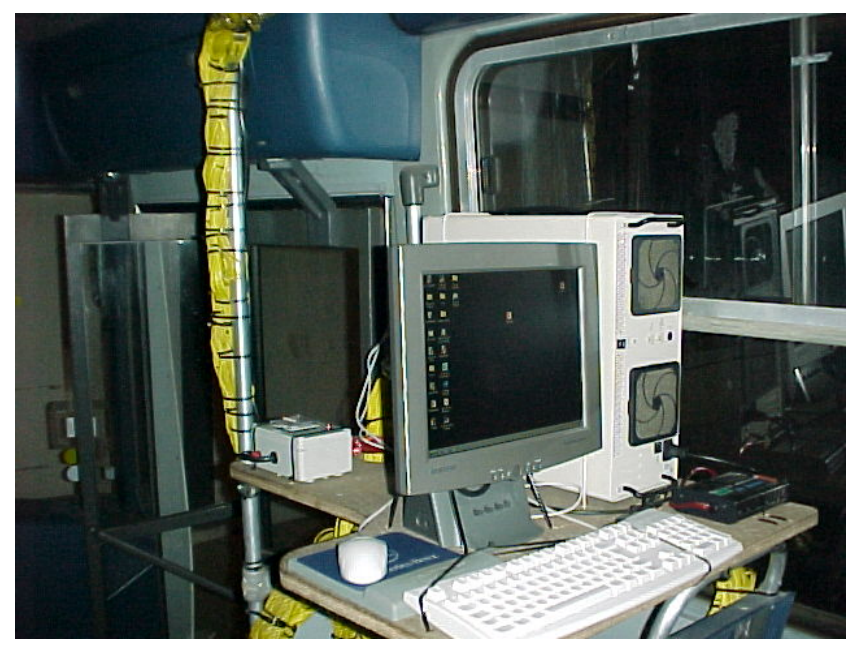

Figura 25 - Sistema de aquisição de dados. 


\subsubsection{PERÍMETRO URBANO}

Os testes foram realizados em perímetro urbano, percorrendo $70 \mathrm{~km}$ em um trecho considerado crítico na Grande São Paulo, com grande número de rampas (aclives e declives), lombadas, valetas, semáforos, curvas (tanto à direita como à esquerda) e pontos de parada de ônibus.

Os testes realizados em perímetro urbano forneceram, entre outros, dois importantes resultados:

- a obtenção das temperaturas de estabilização para os diferentes componentes do sistema de freio, bem como dos diferentes pontos instrumentados em cada componente;

- a avaliação dos pontos mais aquecidos em cada componente e a conseqüente definição de regiões críticas termicamente.

As Figuras 26, 27 e 28 mostram o comportamento térmico de alguns componentes do freio de roda, monitorados durante a realização dos testes em perímetro urbano.

Neste trabalho, no entanto, não serão mostrados em detalhes todos os resultados dos testes em perímetro urbano, bem como de pista de provas, garantindo o sigilo das informações fornecidas pela DaimlerChrysler. Desta forma, a maior parte dos resultados será ilustrada através de curvas de tendência, e embora alguns números não estejam expostos, as escalas entre os gráficos equivalentes será mantida para efeito de comparação. 
Temperatura nos discos de freio

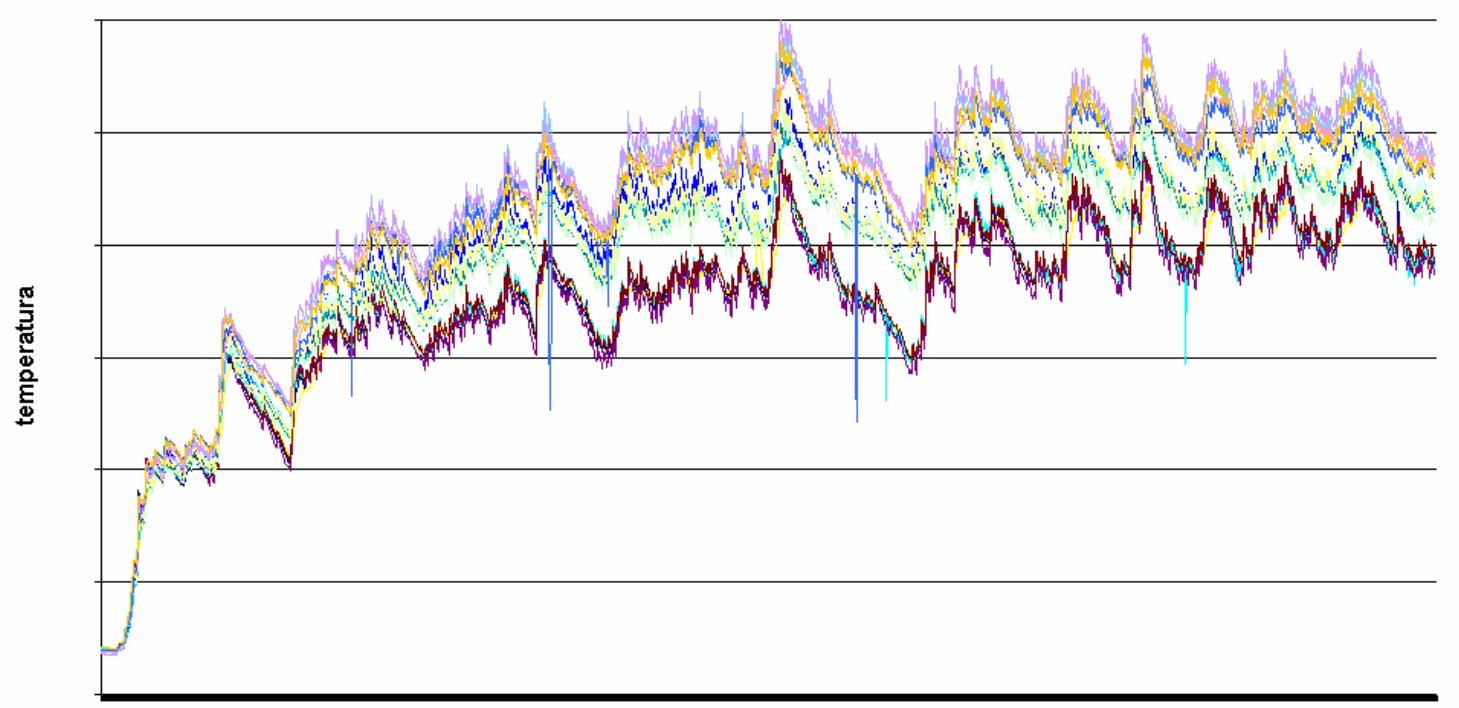

tempo

Figura 26 - Temperatura nos discos de freio em perímetro urbano.

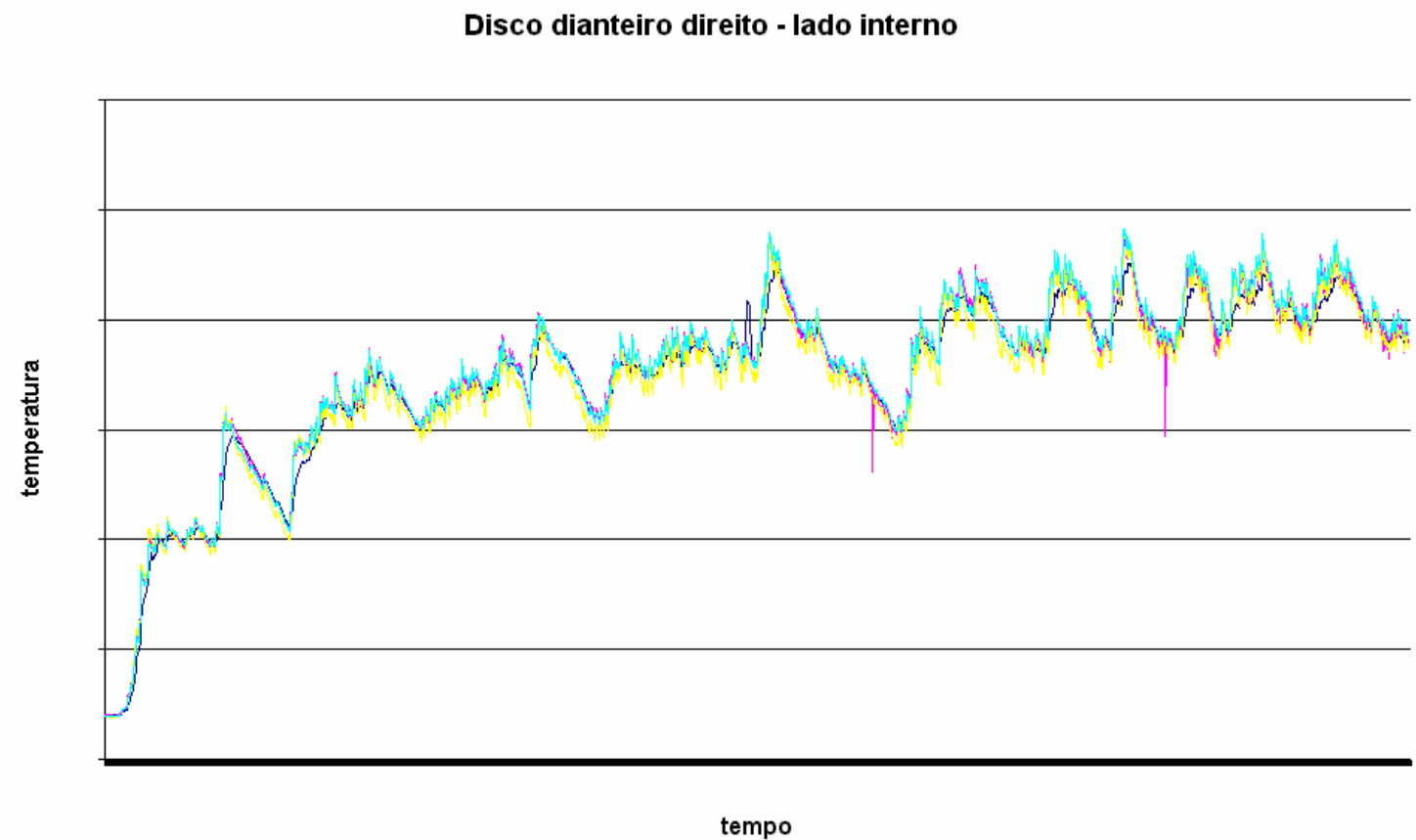

Figura 27 - Temperatura em diferentes pontos instrumentados no disco dianteiro direito (face interna do disco) em perímetro urbano. 
Disco traseiro esquerdo - lado interno

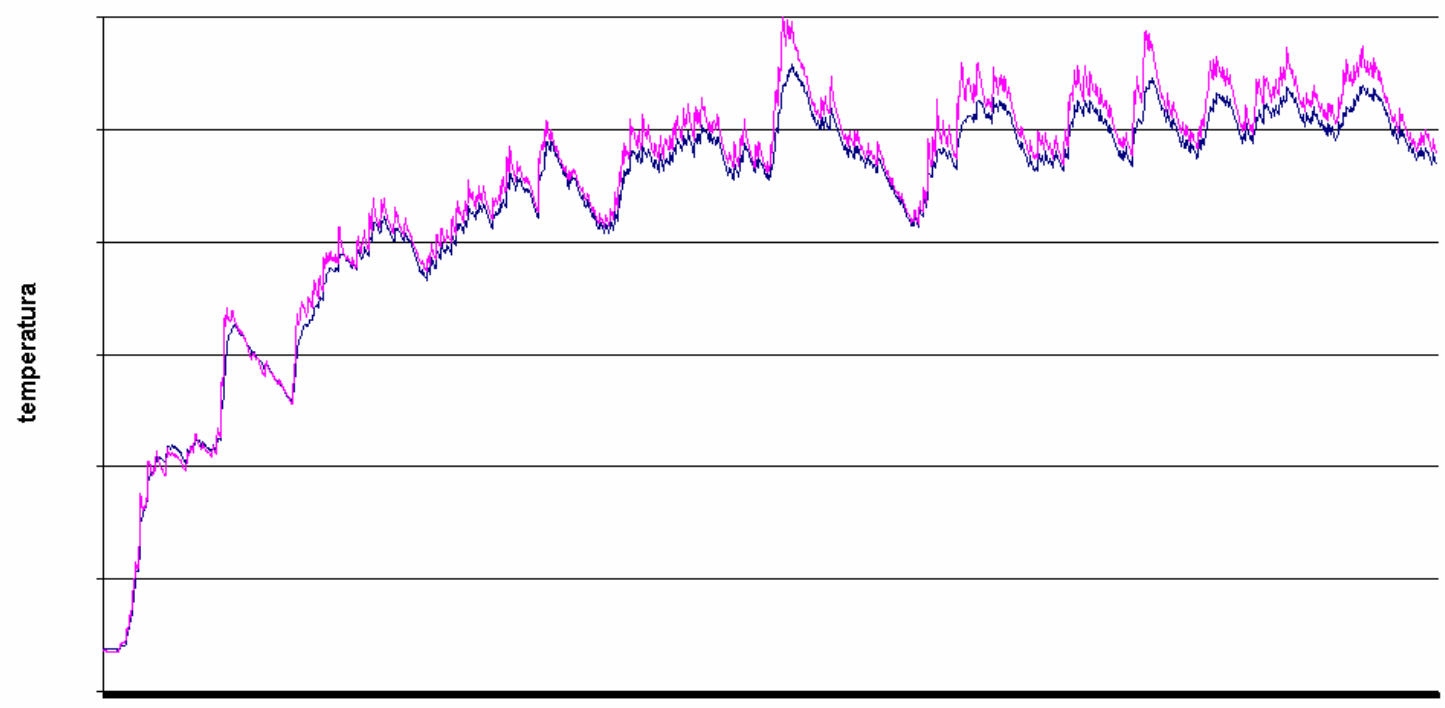

tempo

Figura 28 - Temperatura em diferentes pontos instrumentados no disco traseiro esquerdo (face interna do disco) em perímetro urbano.

A Figura 29 mostra a curva de tendência obtida na medição da temperatura do disco de freio durante o percurso de teste urbano, que teve cerca de três horas e meia de duração. Observa-se que o veículo atinge a temperatura de estabilização entre 2,5 e 3 h. de trajeto. Devido às condições do final do trajeto, passando a trafegar por uma região de condições menos críticas de frenagem, tem início um certo resfriamento.

De forma similar, os demais componentes do sistema mapeado foram monitorados e a partir destes resultados foram definidos os pontos mais críticos do disco de freio, bem como da pastilha. Também foi analisado o comportamento térmico, considerando-se as diferenças entre os lados do veículo e os eixos traseiro e dianteiro, como ilustram as Figuras 30 e 31. 
Temperatura do disco - trecho urbano

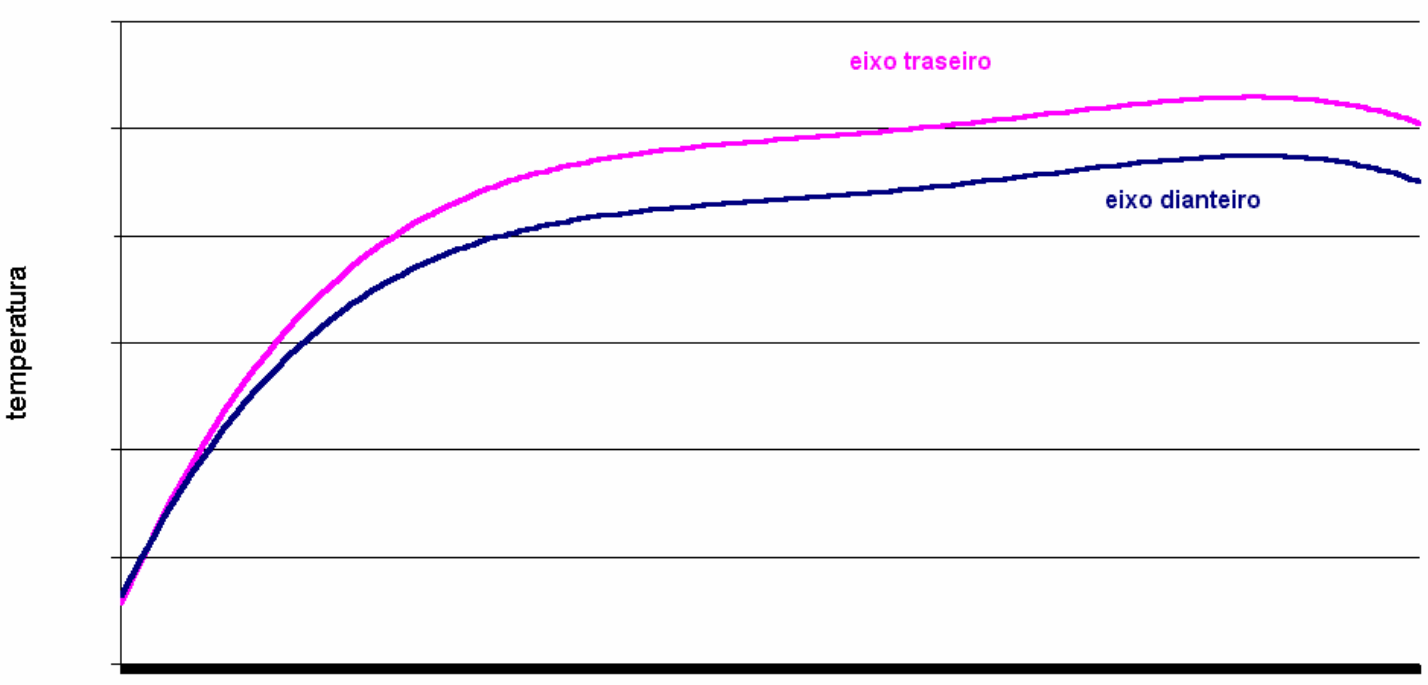

tempo

Figura 29 - Curva de tendência da temperatura do disco de freio em perímetro urbano.

Temperaturas no disco (lado interno) - eixo dianteiro

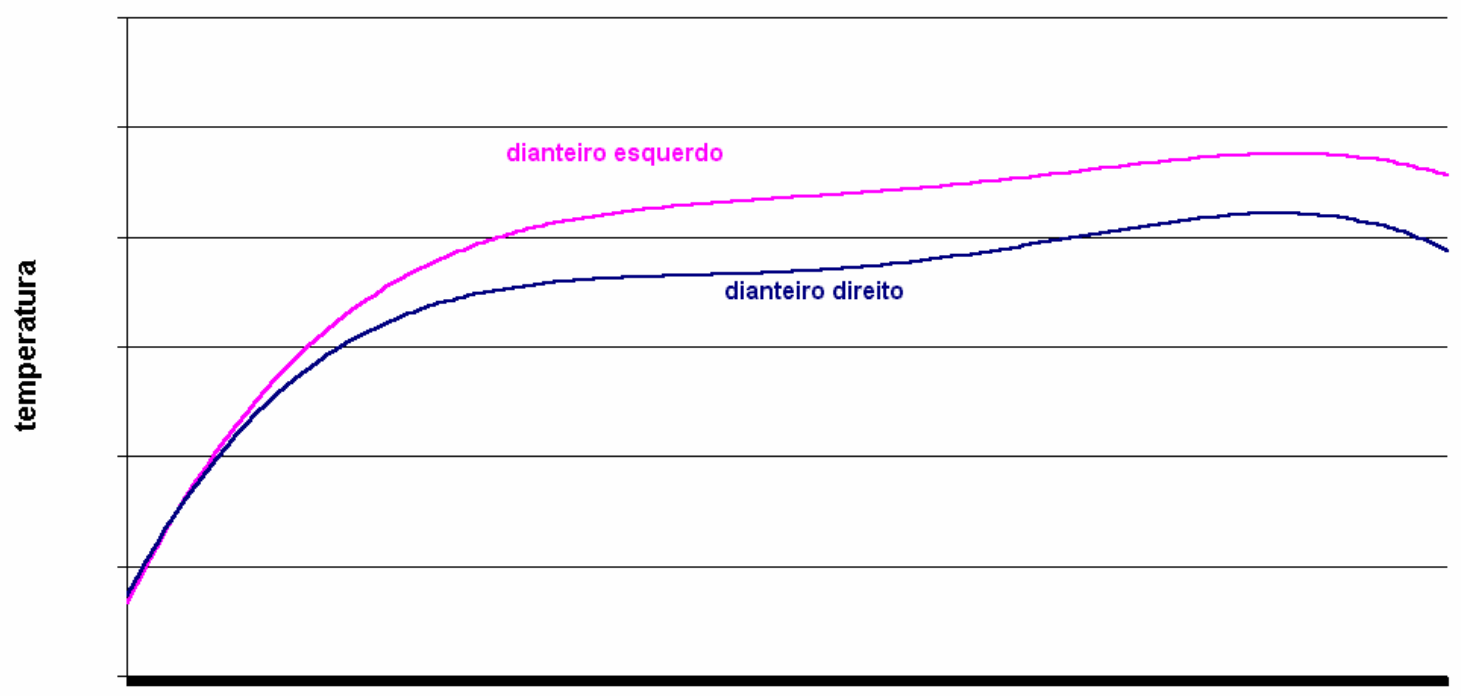

tempo

Figura 30 - Curva de tendência das temperaturas dos discos de freio em perímetro urbano - eixo dianteiro. 
Temperatura nos discos (lado interno) - eixo traseiro

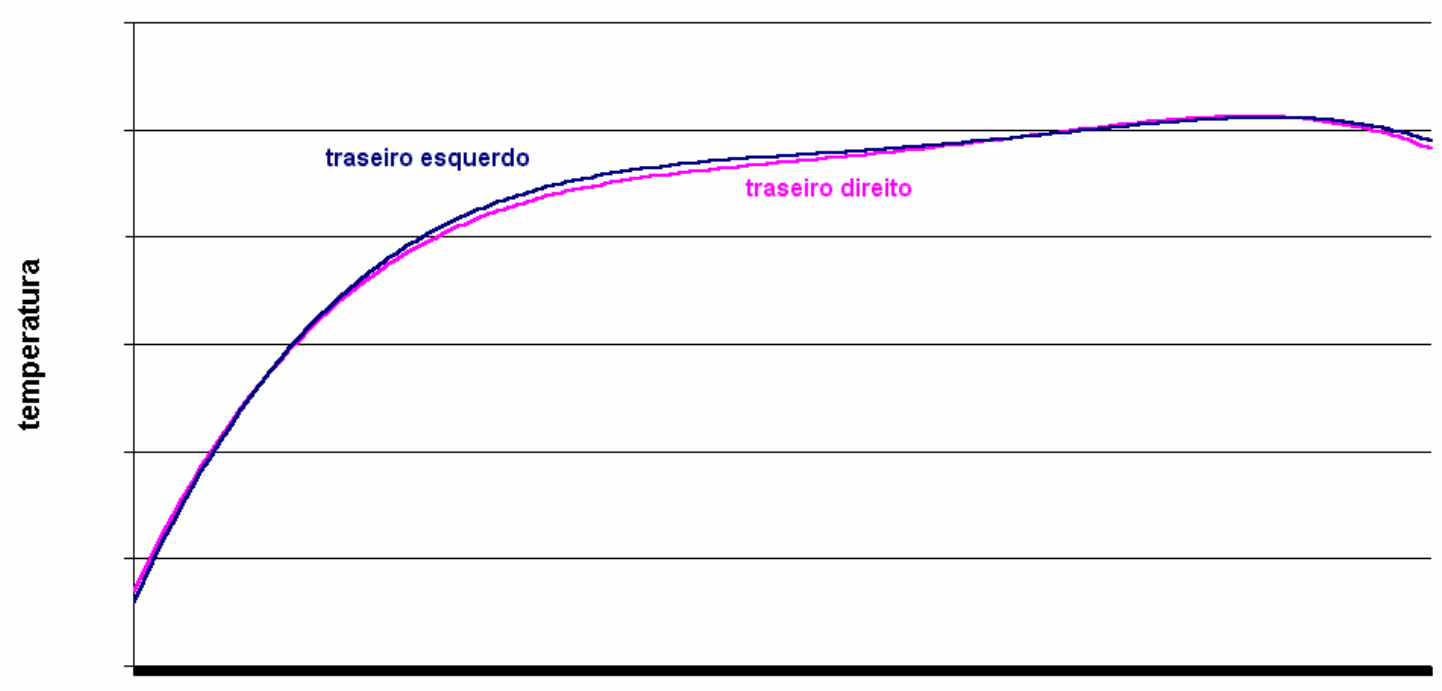

tempo

Figura 31 - Curva de tendência das temperaturas dos discos de freio em perímetro urbano - eixo traseiro.

Foram instalados termopares tanto na face interna como externa do disco, e observadas as diferenças, como mostra a Figura 32.

Apesar das temperaturas mais elevadas do sistema de freios corresponderem ao disco de freio, também foram monitorados os demais componentes, como pastilhas, rolamentos, retentores, cubo de roda e pneus, entre outros. As Figuras 33, 34 e 35 ilustram análises comparativas de alguns destes componentes. A escala destes gráficos corresponde à mesma utilizada para os discos de freio, a fim de oferecer uma maior clareza comparativa, visto que tais valores devem ser mantidos em sigilo industrial. 
Temperatura no disco - eixo traseiro

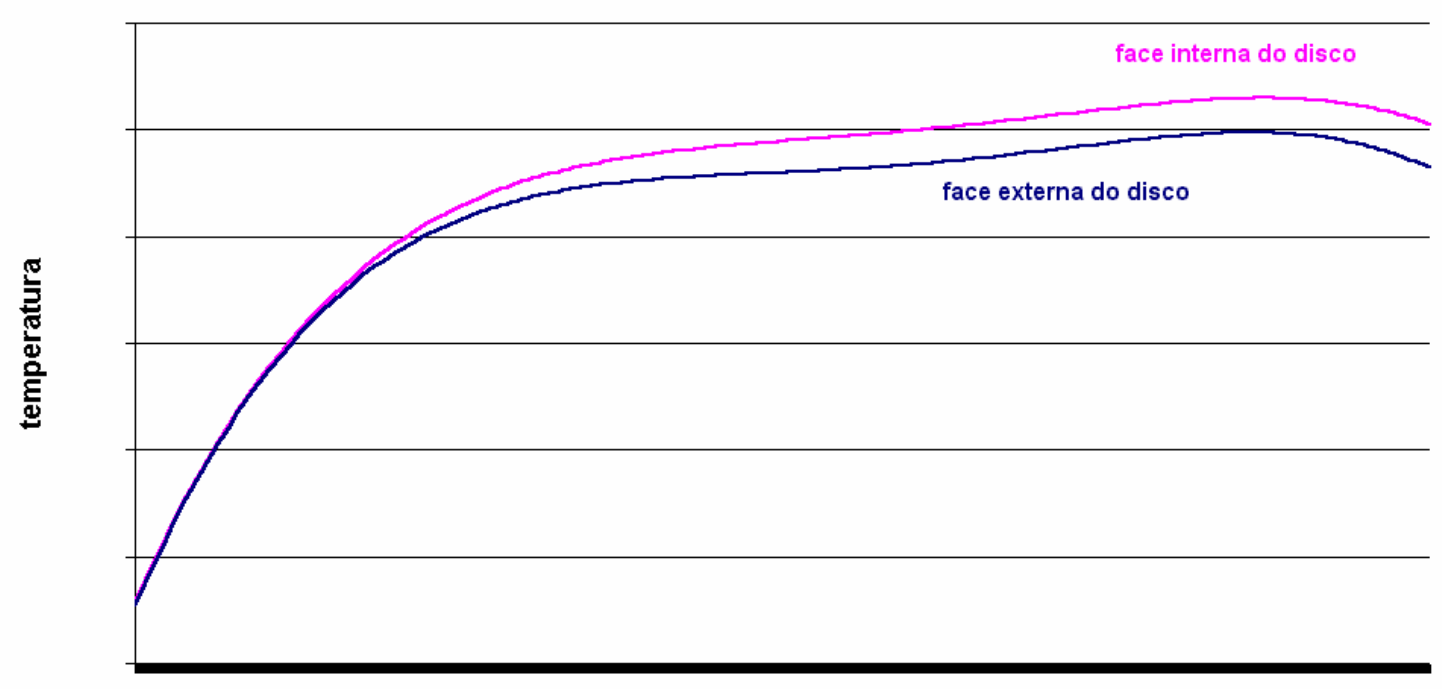

tempo

Figura 32 - Curva de tendência das temperaturas do disco de freio em perímetro urbano -eixo traseiro - lado direito.

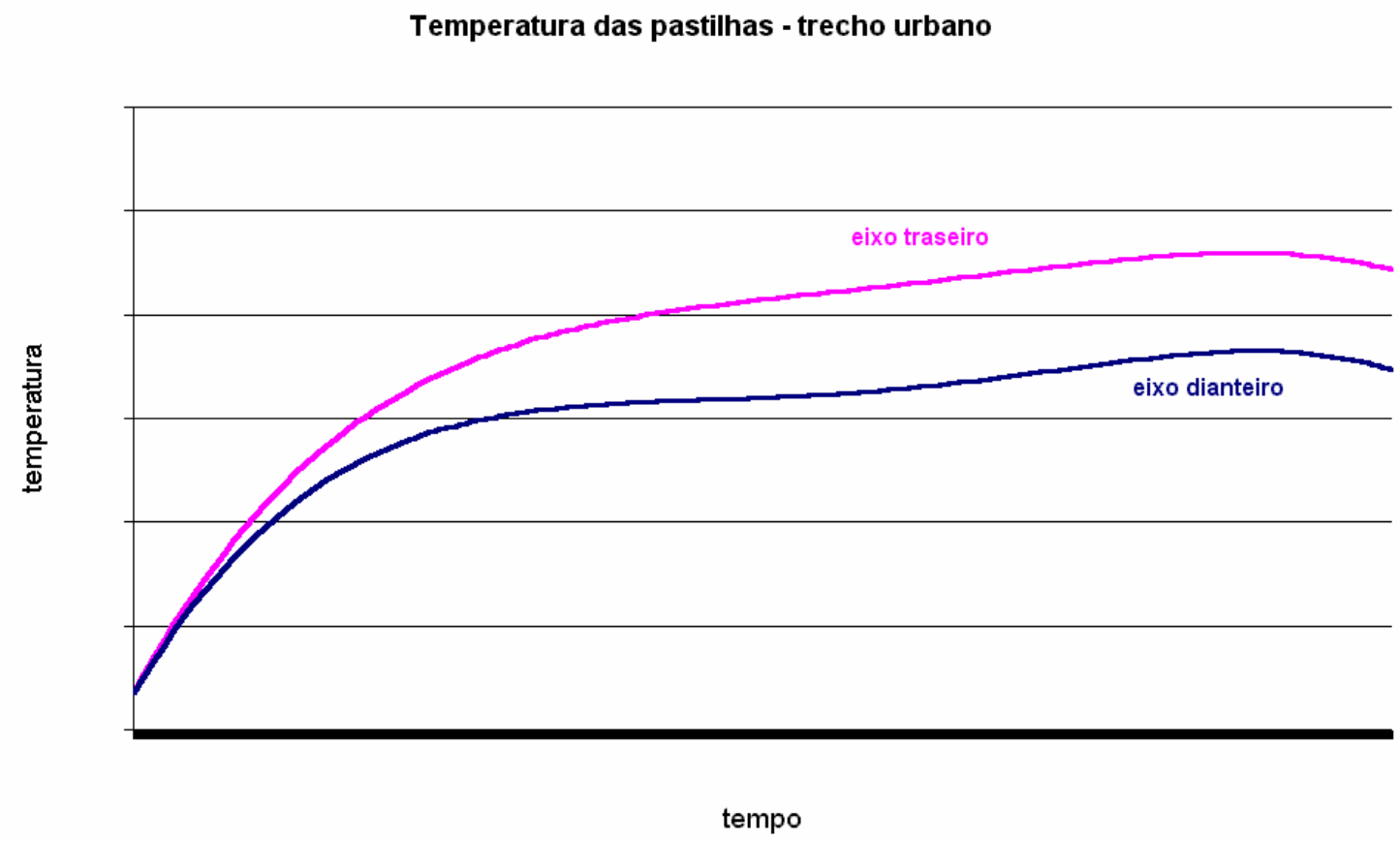

Figura 33 - Curva de tendência das temperaturas das pastilhas em perímetro urbano. 
Temperatura nos pneus - trecho urbano

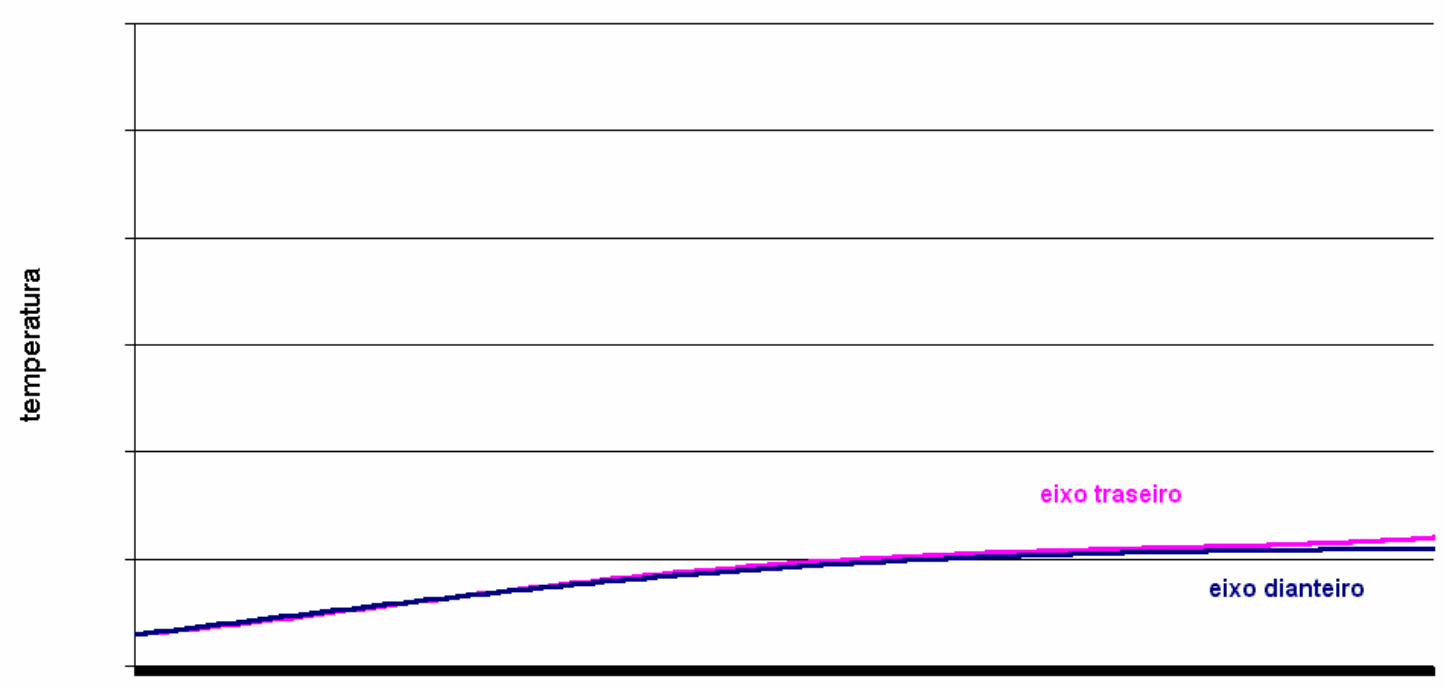

tempo

Figura 34 - Curva de tendência das temperaturas dos pneus em perímetro urbano.

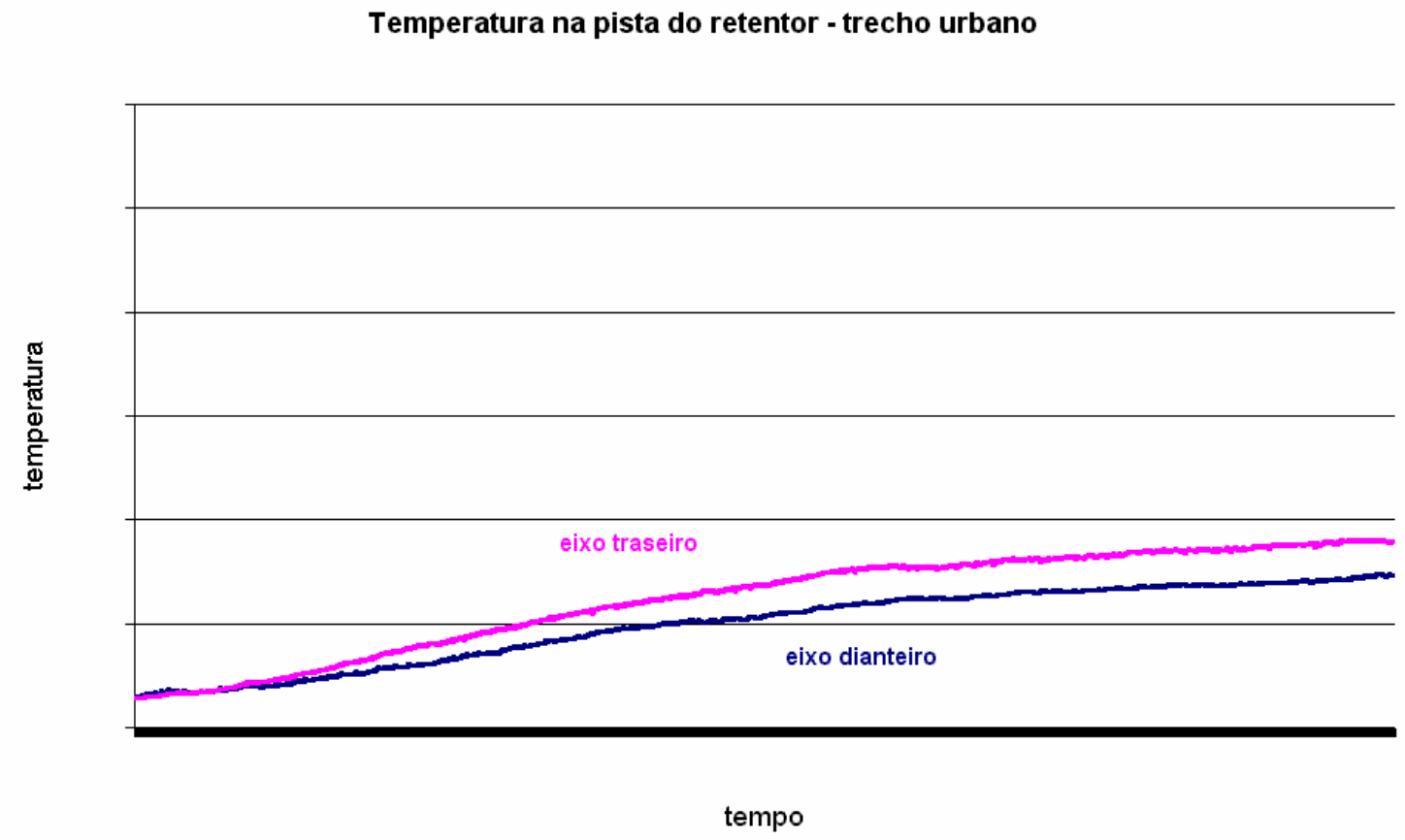

Figura 35 - Curva de tendência das temperaturas das pistas dos retentores em perímetro urbano. 


\subsection{PISTA DE TESTES}

Com relação à pista, o veículo pode trafegar em pistas de asfalto, de concreto, de terra, etc. Tais pistas podem estar molhadas ou secas, em bom ou ruim estado de conservação. Desta forma, tem-se uma grande diversidade de coeficientes de aderência possíveis entre o contato do pneumático com o pavimento, como destacam FERNANDES, CANALE \& ADAS (1998).

Durante o desenvolvimento deste trabalho foram realizados testes na pista de provas da TRW Automotive, em Limeira - SP, ilustrada na Figura 36.

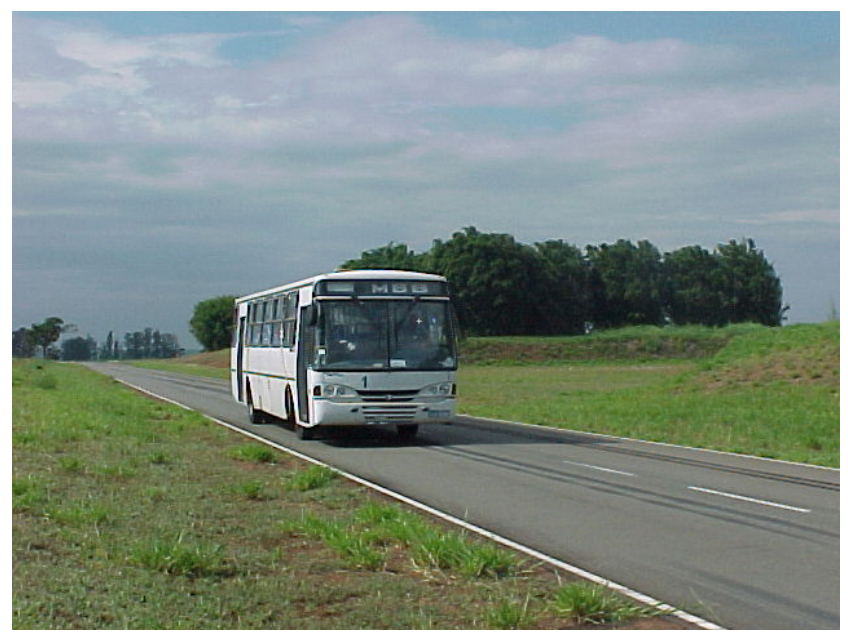

Figura 36 - Pista de testes da TRW em Limeira.

Os testes de pista foram baseados no procedimento padronizado pela Norma NBR 10967, denominado Teste Tipo I, que indica as condições do teste conforme a categoria a que pertence o veículo.

Para o veículo protótipo utilizado, um ônibus urbano, deveriam ser realizadas 20 frenagens com um intervalo de 60 segundos, freando de $60 \mathrm{~km} / \mathrm{h}$ a $30 \mathrm{~km} / \mathrm{h}$, com uma desaceleração de $3 \mathrm{~m} / \mathrm{s}^{2}$.

No entanto, como se buscava observar na pista os níveis térmicos atingidos no trecho percorrido em perímetro urbano, tornou-se necessário triplicar o teste padrão, realizando 60 frenagens, quando somente assim as temperaturas de estabilização dos discos e pastilhas foram atingidas. 
Todos os testes foram realizados partindo-se de temperaturas inferiores à $100^{\circ} \mathrm{C}$ no freio, como recomenda ainda a Norma NBR 10967.

A partir da avaliação dos resultados obtidos no perímetro urbano foi possível selecionar os pontos mais importantes termicamente, somente os quais passaram a ser monitorados nos testes de pista.

Antes da realização de cada teste, os termopares eram devidamente conferidos e calibrados, evitando assim erros de leitura no sistema de aquisição de dados.

Os primeiros testes em pista foram realizados com o veículo em sua configuração padrão, com carga máxima de 17 toneladas, discos e pastilhas novos e assentados e com pista seca.

A fim de evitar o desgaste irregular da pista de testes, o sentido de utilização (horário e anti-horário) é diariamente alternado.

Para avaliar o efeito de tal mudança de sentido na avaliação térmica do freio, foram realizados testes, tendo como única variável, o sentido de utilização da pista.

As Figuras 37 e 38 mostram a influência insignificante que há na temperatura de discos e pastilhas em virtude da variação do sentido de utilização da pista de testes, com diferenças inferiores à $10^{\circ} \mathrm{C}$.

A temperatura dos pneus sofre alguma variação em virtude das possíveis diferenças de ventilação em relação ao sentido da pista, como mostra a Figura 39. No entanto, observa-se que no período de teste em que foram monitorados os pneus sob diferentes sentidos de direção, não foi possível atingir a temperatura de estabilização dos pneus. É possível que quando os pneus atingirem estes níveis térmicos, a influência de sentido da pista também passe a ser desprezível. 


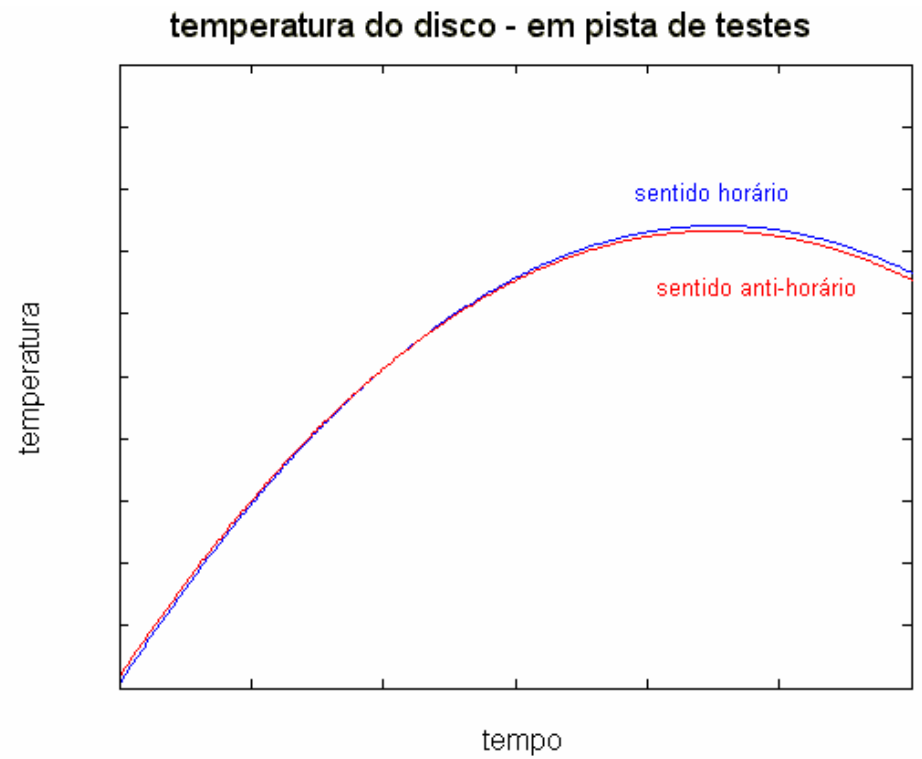

Figura 37 - Comparativo do sentido da pista de testes - temperatura dos discos de freio.

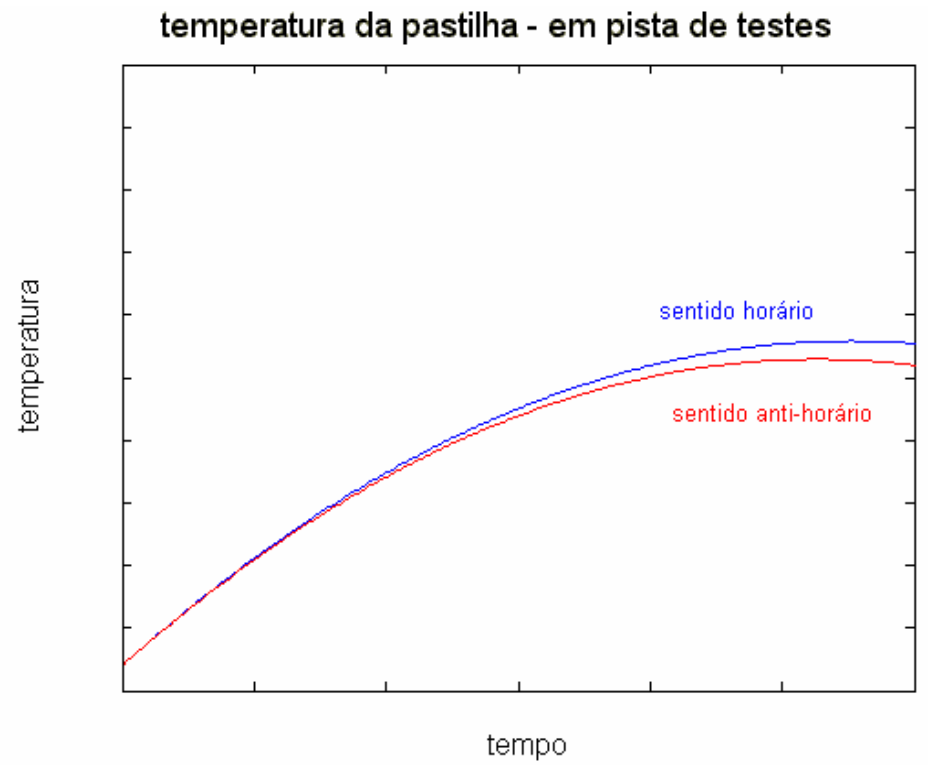

Figura 38 - Comparativo do sentido da pista de testes - temperatura das pastilhas. 


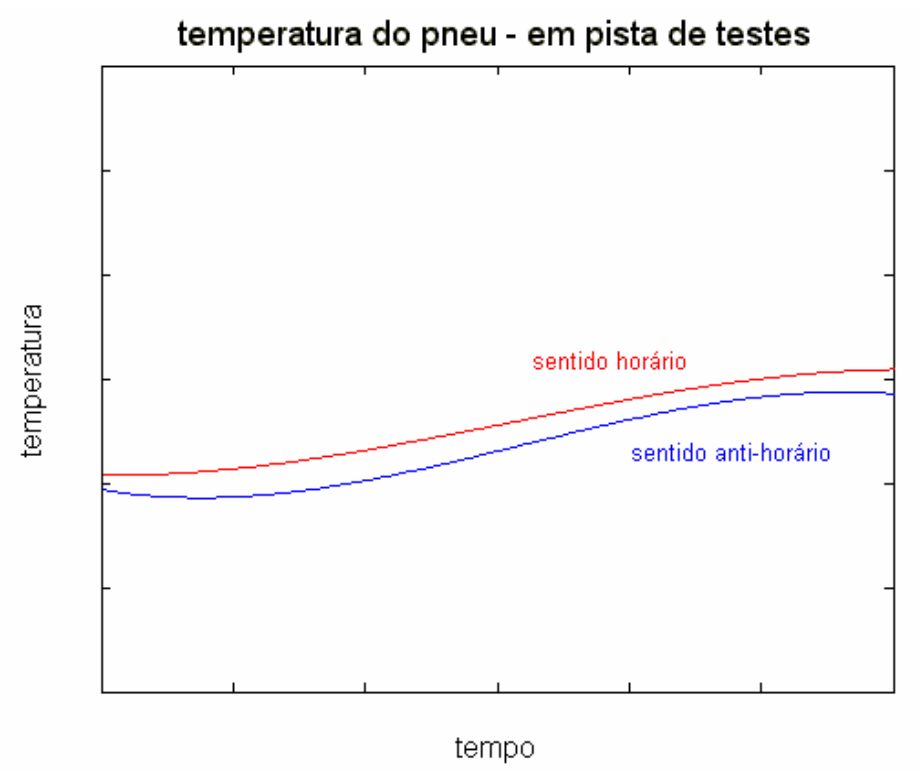

Figura 39- Comparativo do sentido da pista de testes - temperatura dos pneus.

Com o veículo em sua configuração padrão, com carga máxima, duas possíveis modificações no sistema de freios foram ainda avaliadas:

- Ventilação forçada: um sistema de ventilação foi instalado em cada freio de roda, conduzindo ar através de dutos direcionados à região de contato disco/pastilha, como ilustram as Figuras 40, 41 e 42;

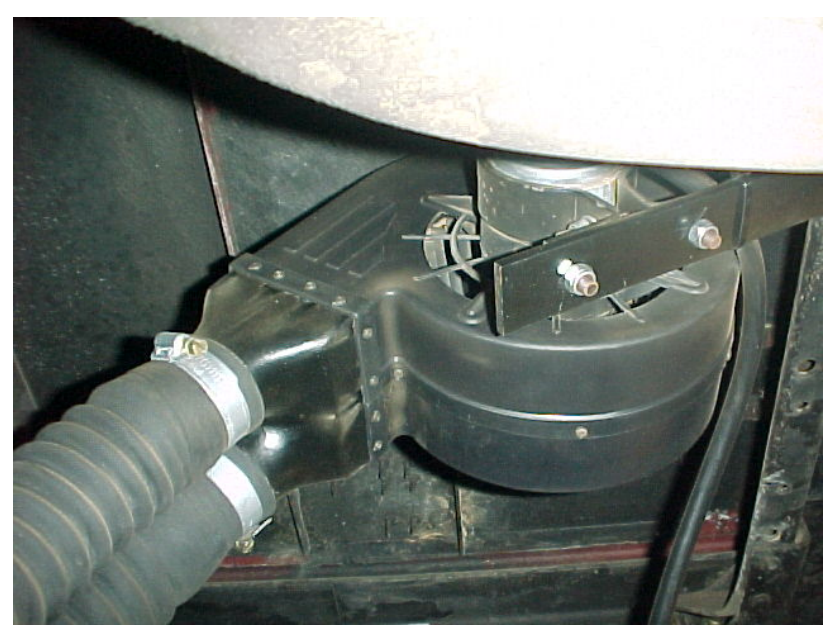

Figura 40 - Fixação do sistema de ventilação forçada. 


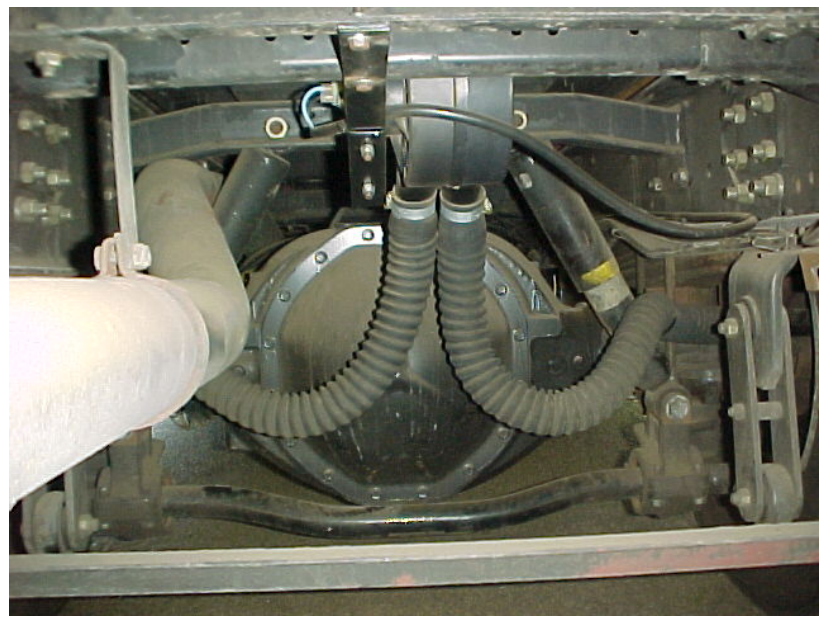

Figura 41 - Vista dos dutos de ventilação forçada.
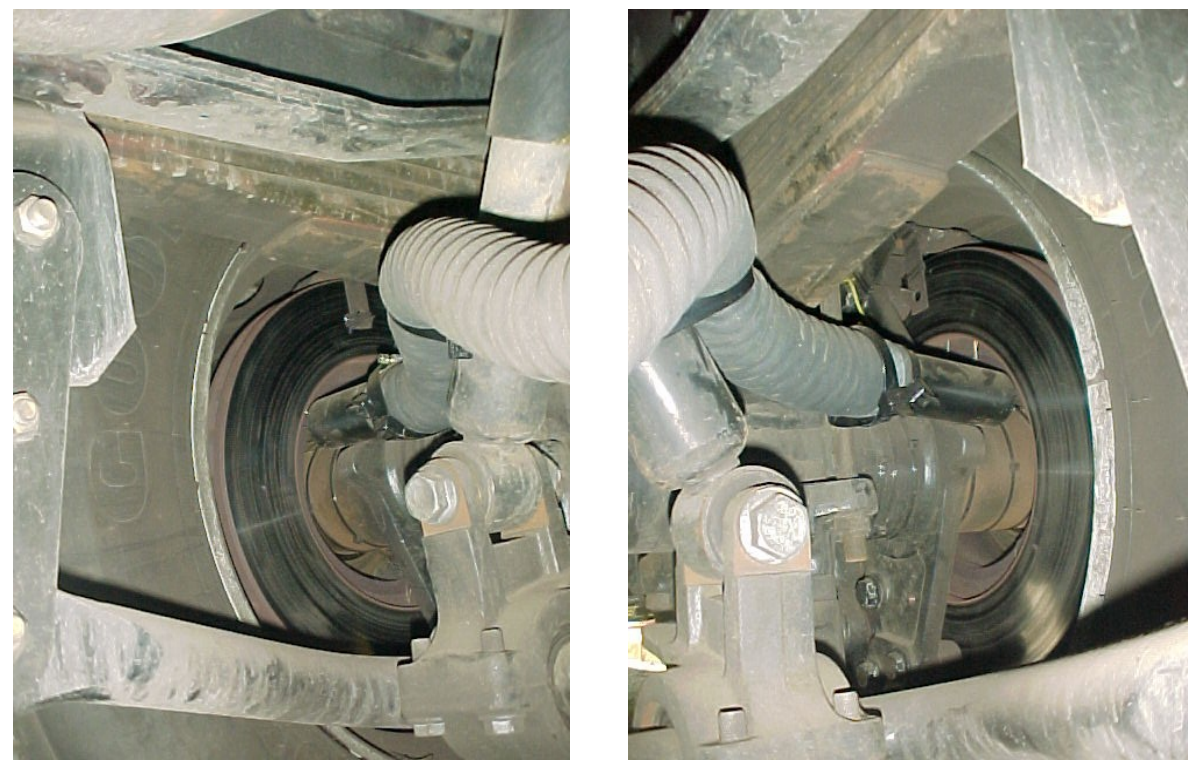

Figura 42 - Dutos de ventilação forçada direcionados aos discos.

As Figuras 43 e 44 mostram a variação de temperatura do disco entre a configuração padrão e o sistema com ventilação forçada. Pode-se observar que devido ao maior aquecimento que ocorre no eixo traseiro, o resfriamento obtido também é mais eficiente neste eixo, cerca de 30\% de redução de temperatura. Já no eixo dianteiro ocorre cerca de $20 \%$ de redução de temperatura nos discos de freio. 


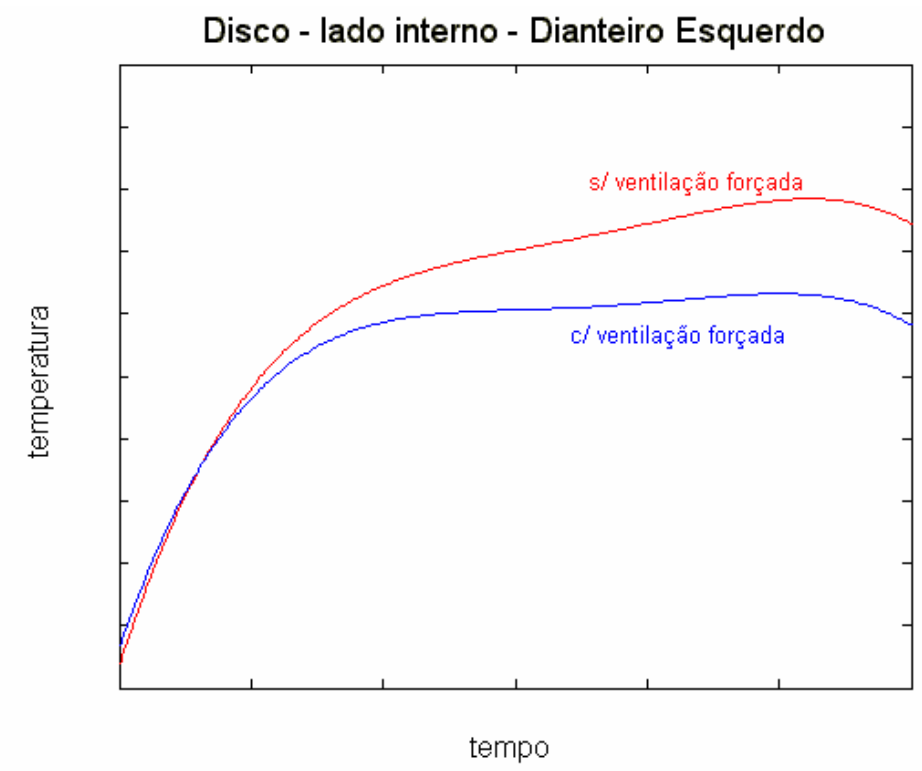

Figura 43 - Comparativo das temperaturas atingidas no disco de freio dianteiro considerando o efeito da ventilação forçada.

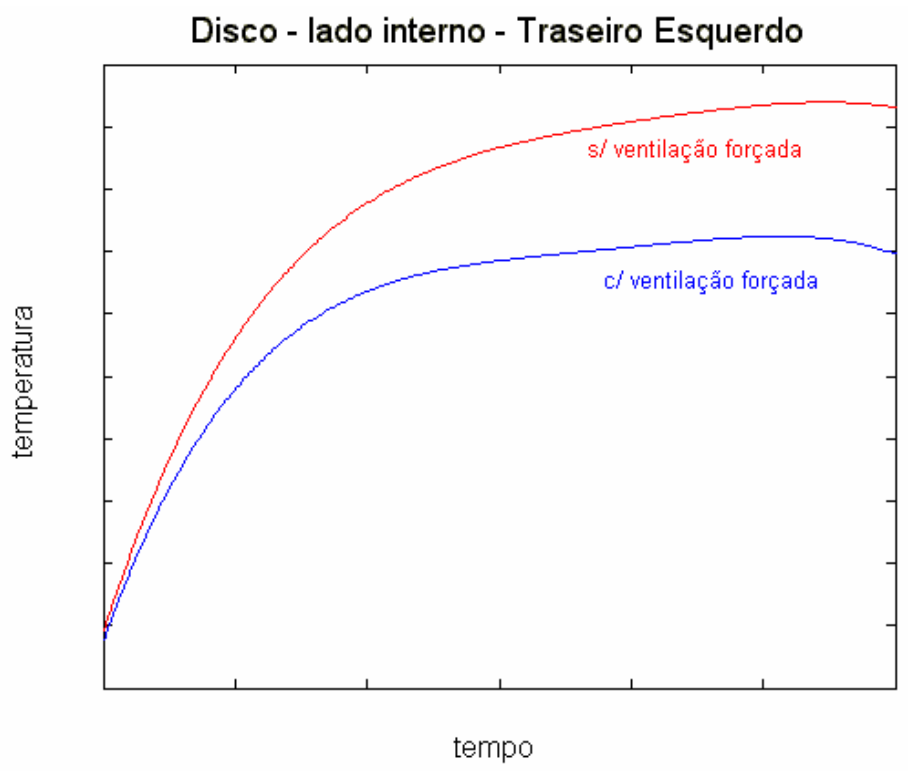

Figura 44 - Comparativo das temperaturas atingidas no disco de freio traseiro considerando o efeito da ventilação forçada.

- Espelho: uma placa de proteção foi instalada em cada roda, protegendo o sistema de resíduos e sujeira, como ilustram as Figuras 45 e 46. 


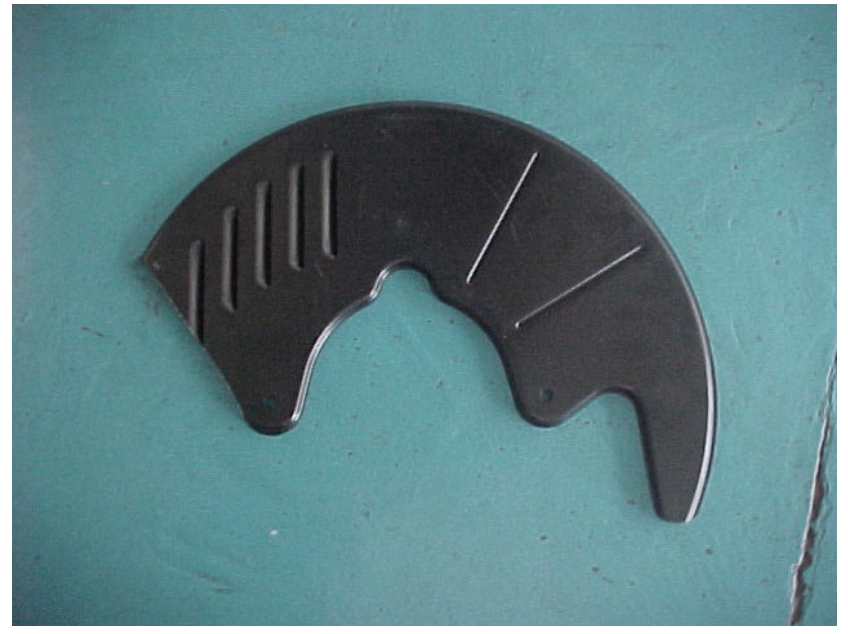

Figura 45 - Placa de proteção - espelho

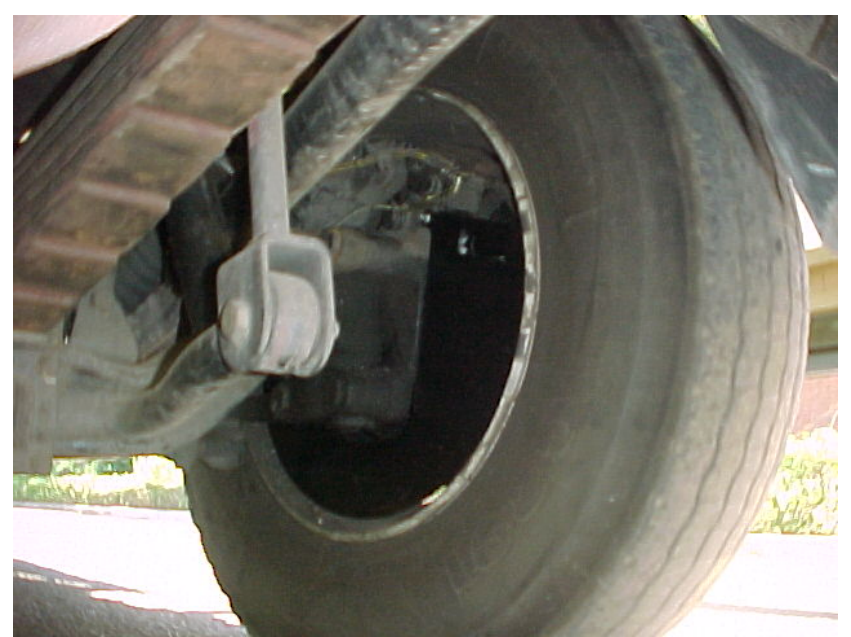

Figura 46 - Espelho instalado em uma das rodas do veículo.

O efeito do espelho, termicamente mostrou-se muito negativo no eixo dianteiro, reduzindo muito a ventilação do sistema de freios, como mostra a Figura 47, aumentando as temperaturas do disco em quase $20 \%$. No entanto, no eixo traseiro, cuja ventilação já é bastante precária, a introdução do espelho praticamente não teve qualquer efeito térmico sobre o disco de freio, como mostra a Figura 48. 


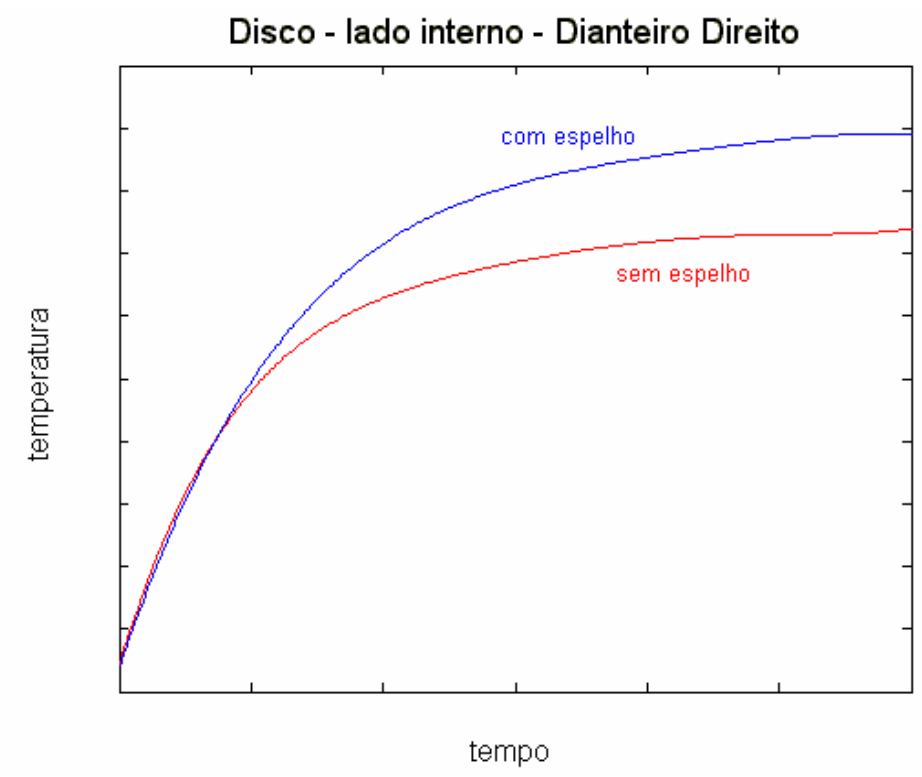

Figura 47 - Comparativo das temperaturas atingidas no disco de freio dianteiro considerando o efeito do espelho.

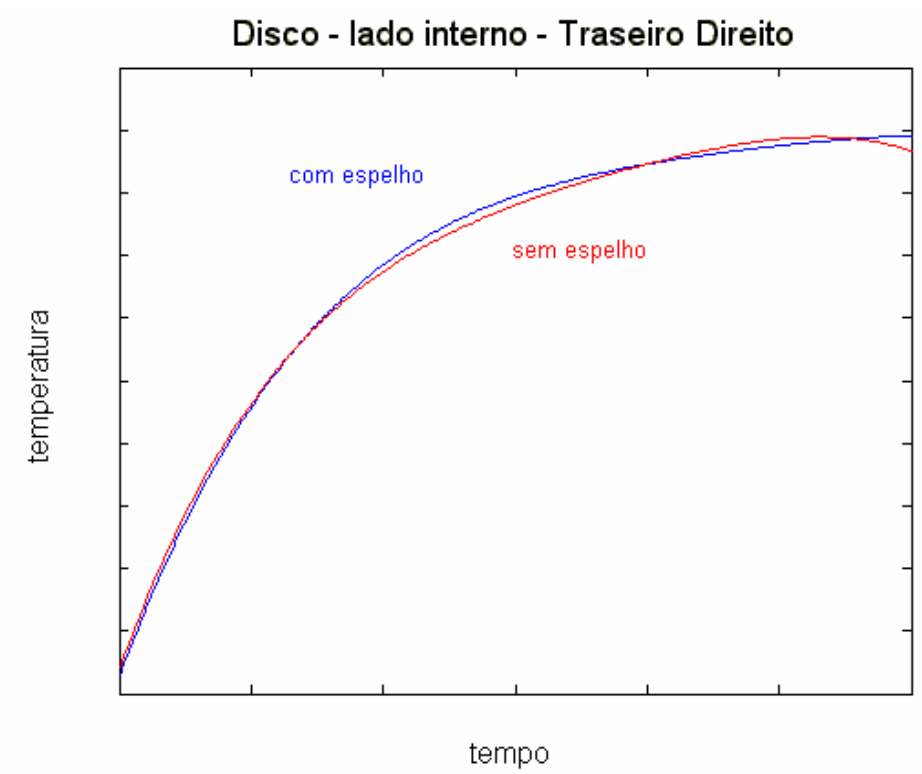

Figura 48 - Comparativo das temperaturas atingidas no disco de freio traseiro considerando o efeito do espelho.

Em seguida, o veículo foi testado com apenas meia-carga e também na condição vazio. O carregamento do veículo foi realizado através de barris com água, amarrados aos bancos e também nos corredores do veículo, como ilustra a Figura 49. 


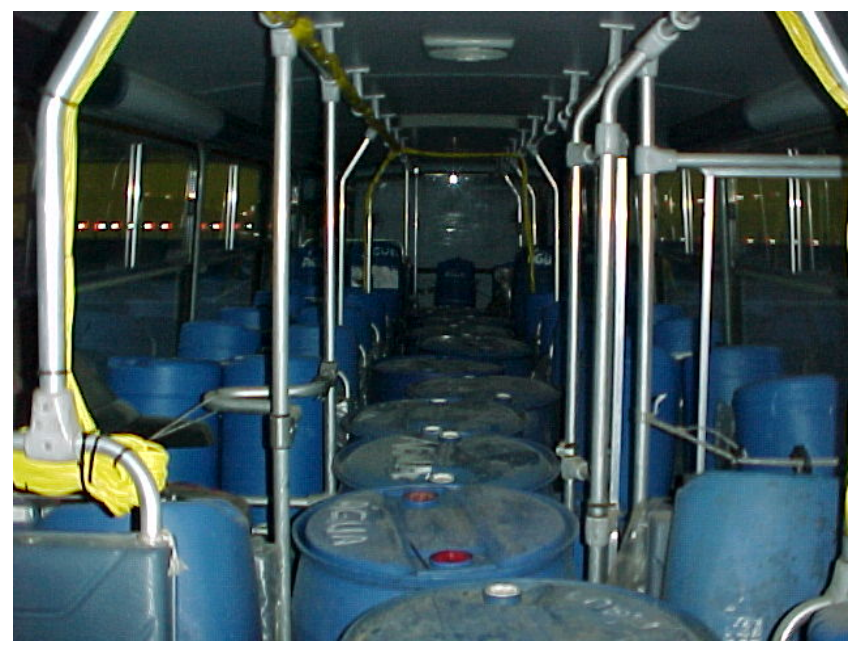

Figura 49 - Vista do carregamento do veículo.

Como se esperava, a redução da temperatura no disco de freio é proporcional à diminuição da carga do veículo, visto que a energia cinética é transformada em energia térmica na frenagem. As Figuras 50 e 51 mostram as curvas obtidas durante os testes com diferentes condições de carregamento.

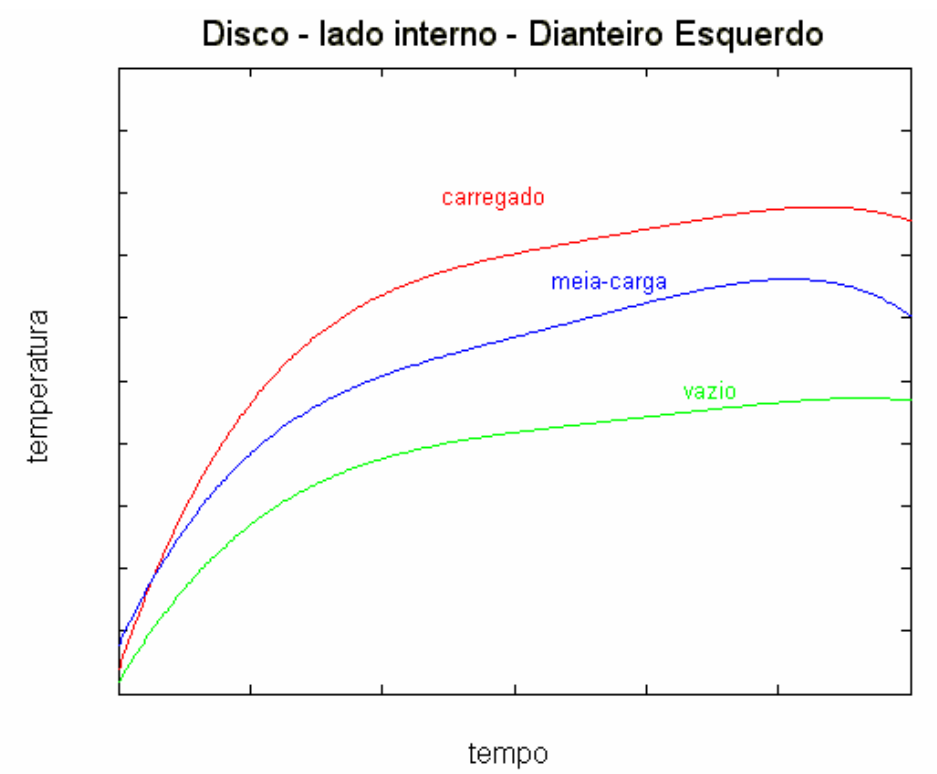

Figura 50 - Comparativo das temperaturas atingidas no disco de freio dianteiro considerando a variação de carga. 


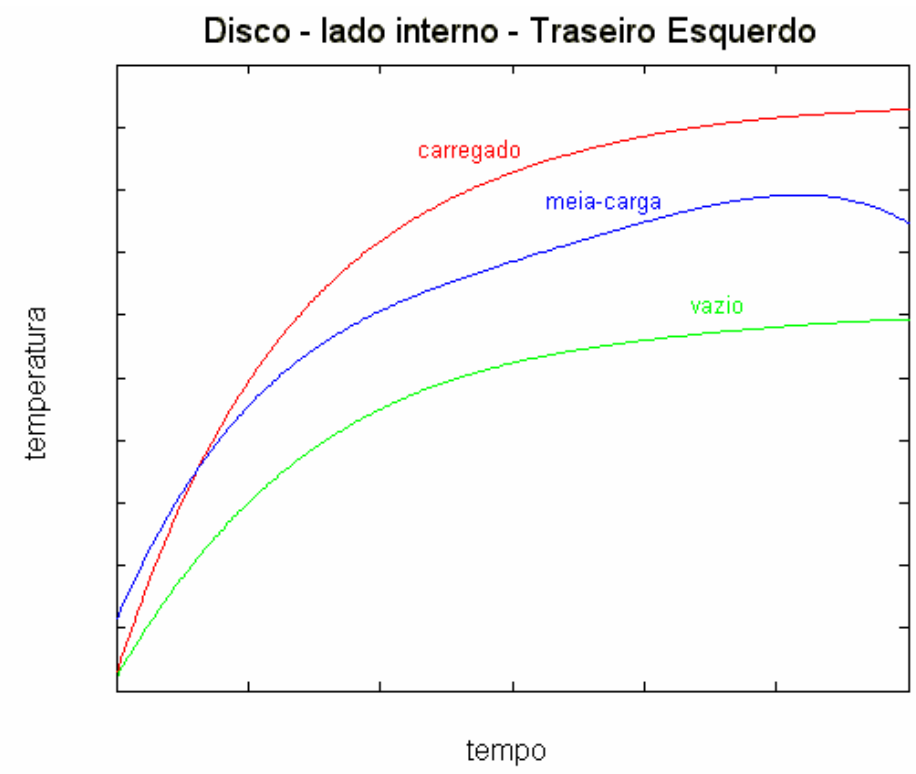

Figura 51 - Comparativo das temperaturas atingidas no disco de freio traseiro considerando a variação de carga.

\subsection{DINAMÔMETRO}

Testes formais em rodovias e pistas de prova vem sendo feitos desde os anos 30, usando o estado da arte em equipamentos veiculares com instrumentos rudimentares. Aplicando o mesmo tipo de técnicas de instrumentação para com os testes em bancadas, os equipamentos foram se tornando mais sofisticados, como os dinamômetros usados atualmente, medindo e registrando temperaturas em diferentes componentes de freios a tambor e a disco, curso do pedal, distâncias de frenagem, desaceleração e velocidade na frenagem, como salienta SMALES (1994).

Os ensaios em dinamômetros também são interessantes, principalmente para observar as variações do fator de freio do veículo estudado.

Segundo GOHRING \& VON GLASNER (1988), no dinamômetro, a energia da massa do veículo freando é simulada por uma massa rotacionando e sendo parada pelos freios a serem testados. Sugerem a utilização do dinamômetro para determinação de alguns fatores, tais como: 
- correlação entre os valores do fator de freio e os parâmetros de temperatura, velocidade e pressão;

- correlação entre o desgaste e os mesmos parâmetros;

- distribuição de temperatura e pressão;

- deformação do disco como resultado da influência da temperatura.

Destacam ainda que o dinamômetro pode ser útil para testar combinações de freios e suas influências mútuas, bem como a distribuição de forças de frenagem no veículo.

SCHWARTZ \& RHEE (1977) descreveram simulações em dinamômetro e propuseram que elas ofereciam melhores resultados em reproduzir o desgaste das pastilhas de freio do que os testes em veículos.

Neste trabalho foram realizados testes em dinamômetro inercial no laboratório da Fras-Le em Caxias do Sul, ilustrado na Figura 52.

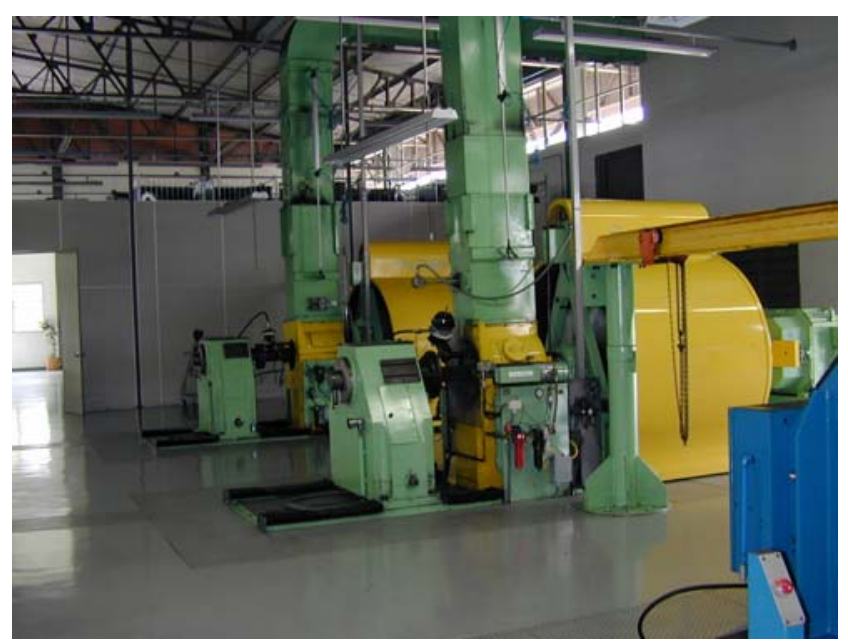

Figura 52 - Dinamômetros inerciais no laboratório de testes da Fras-le.

O sistema de freios a disco similar ao usado no veículo de testes foi montado no dinamômetro inercial, como mostra Figura 53.

Um disco de freio novo foi utilizado, a fim de garantir que este estivesse livre de quaisquer distorções. No entanto, antes de realizar os ensaios, foi feito o assentamento das pastilhas, para assegurar a máxima conformidade entre o contato 
disco/pastilha durante os testes. O procedimento de assentamento também é utilizado nos testes de pista e no perímetro urbano.

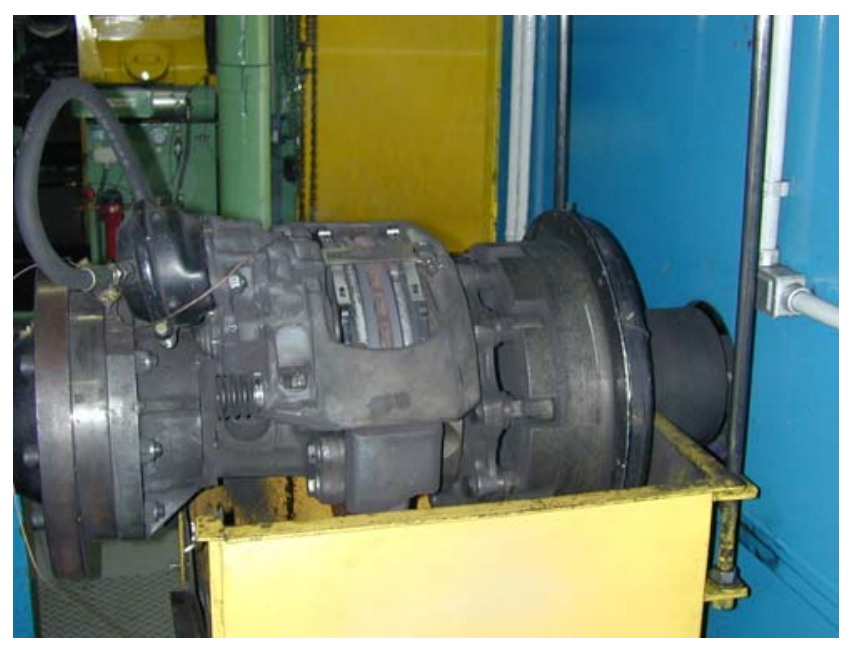

Figura 53 - Sistema de freio a disco montado em dinamômetro inercial.

Pela utilização de diferentes números de volantes, conforme ilustra a Figura 54, a inércia da máquina pode ser ajustada para oferecer aproximadamente a energia cinética necessária para a velocidade apropriada do eixo de direção, a fim de simular as condições obtidas no veículo em pista.

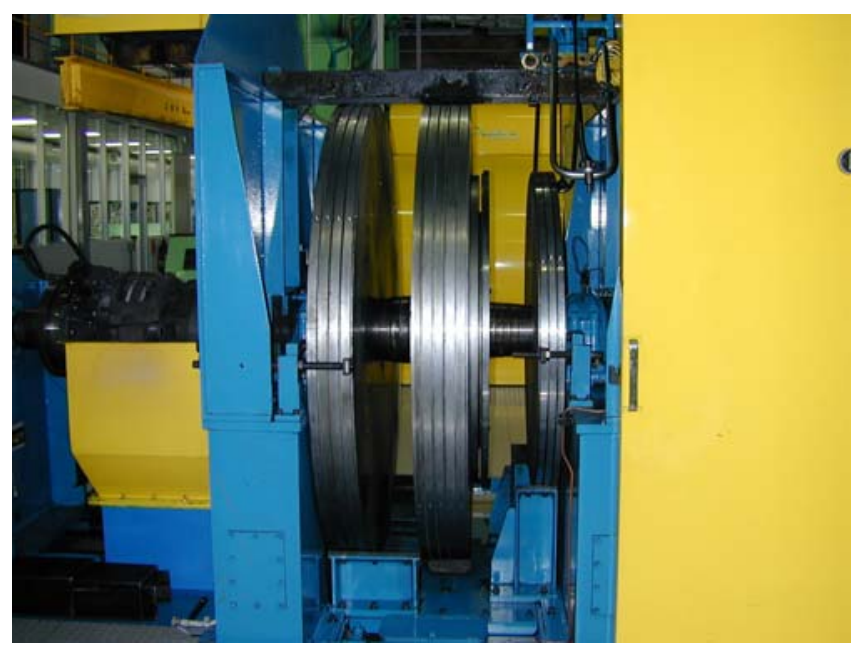

Figura 54 - Volantes do dinamômetro inercial. 
As temperaturas foram monitoradas através de três termopares no disco de freio e um termopar na pastilha.

Além das temperaturas foram também monitorados os seguintes fatores:

- $\quad$ velocidade de frenagem;

- tempo de frenagem;

- desaceleração;

- torque;

- pressão;

- distância de frenagem.

Os testes foram realizados definindo valores de velocidade e pressão semelhantes aos atingidos em perímetro urbano.

Outra variável foi ainda adicionada, realizando os ensaios em duas condições distintas, sem ventilação e com ventilação de $20 \mathrm{~km} / \mathrm{h}$.

Por tratar-se de uma simulação em bancada, foi ainda possível permitir de forma segura, que o sistema de freio atingisse níveis muito altos de temperatura, viabilizando uma melhor definição das curvas de fator de freio. Na Figura 55 é possível observar a mudança na coloração do disco diante de temperaturas bastante elevadas. As Figuras 56 e 57 mostram as curvas características do fator de freio em relação à temperatura do disco, com e sem ventilação respectivamente.

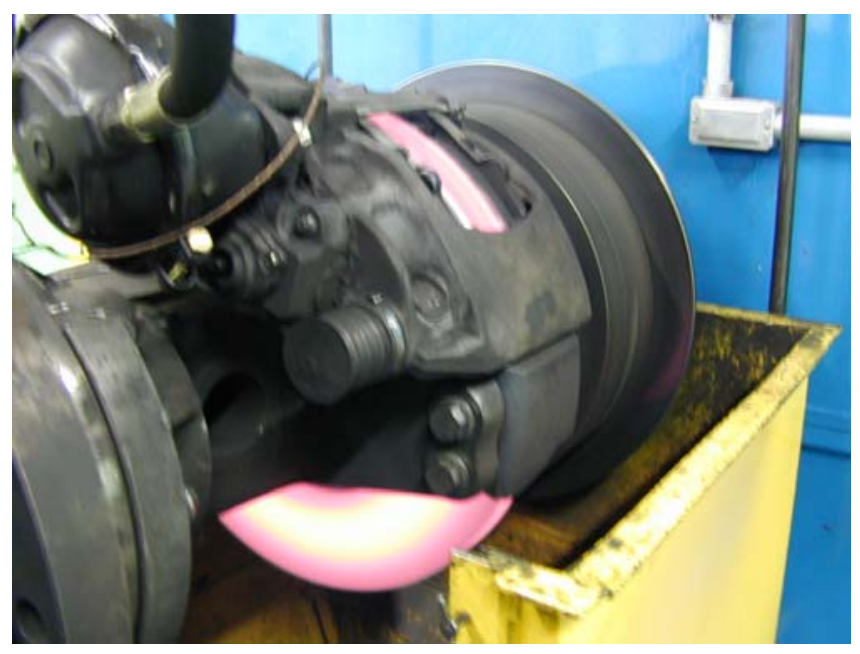

Figura 55 - Disco de freio sob elevadas temperaturas. 
Fator de freio x Temperatura (sem ventilação)

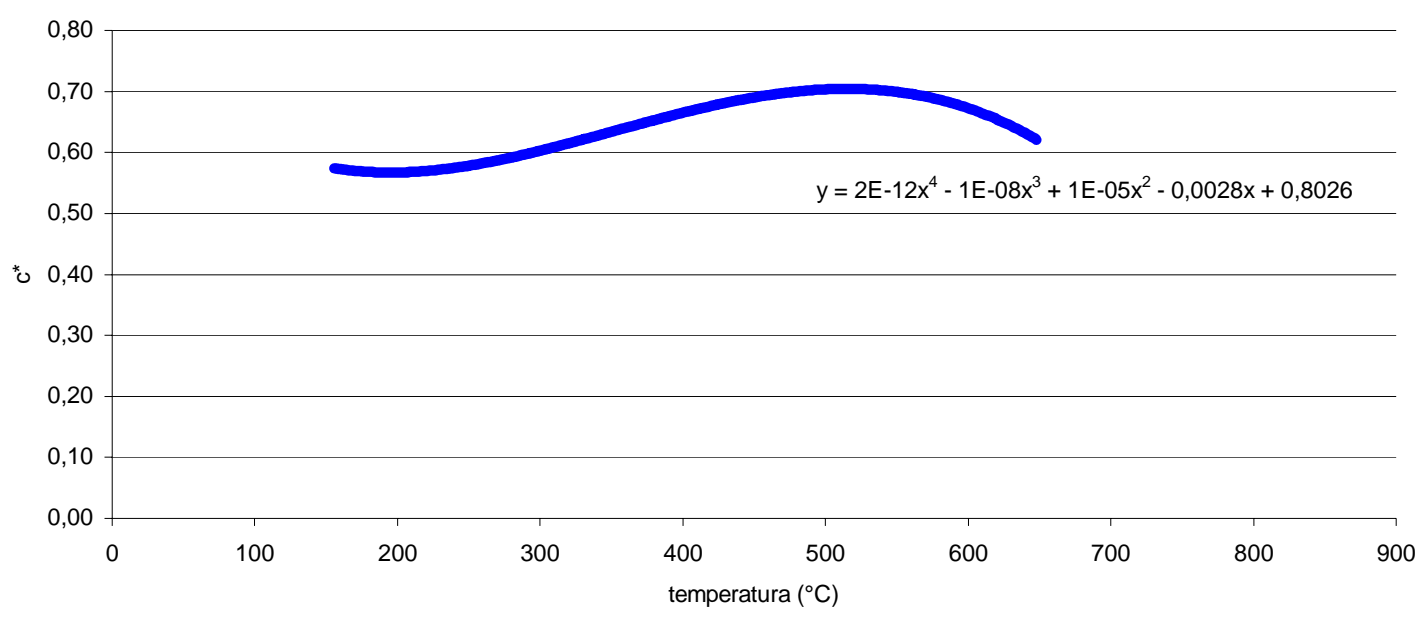

Figura 56 - Curva característica do fator de freio, sem a presença de ventilação.

Fator de freio x Temperatura do disco (com ventilação)

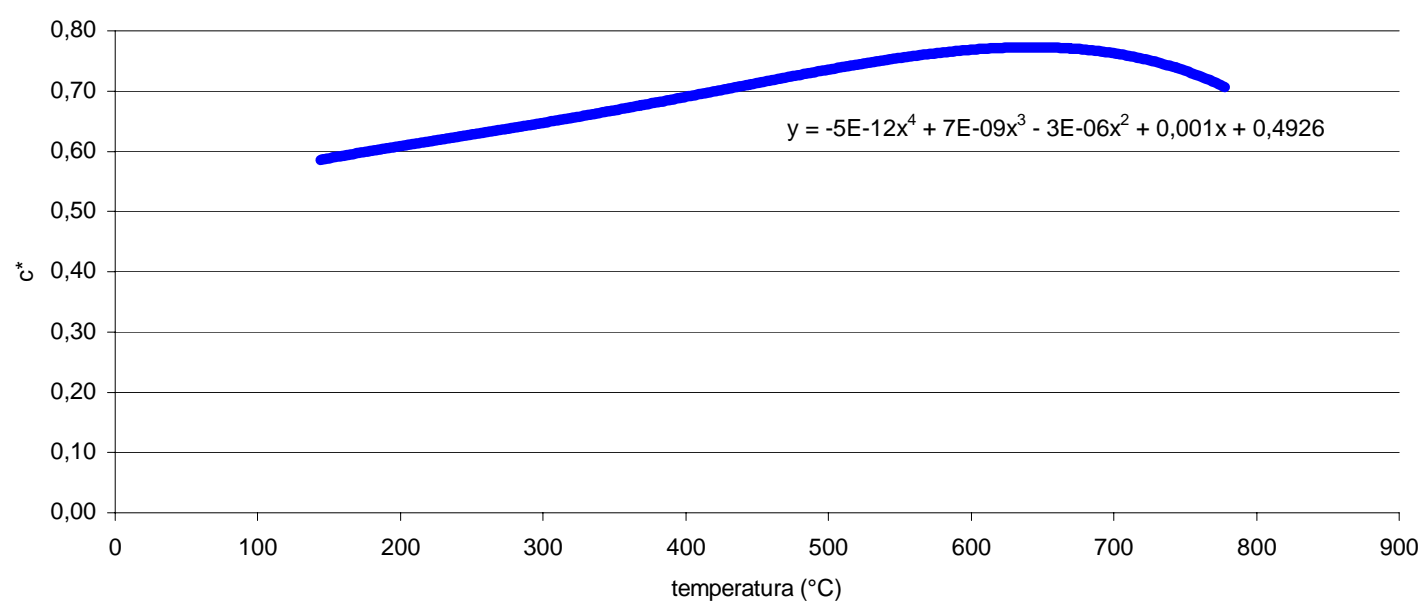

Figura 57 - Curva característica do fator de freio, com presença de ventilação.

Através das curvas características do fator de freio obtidas em dinamômetro, é possível observar-se que o material de atrito avaliado é de boa qualidade, não apresentando variações bruscas com a mudança de temperatura durante o processo de frenagem. 
Além das medidas térmicas feitas através dos termopares instalados no disco, também foi possível realizar-se uma análise termográfica do disco de freio através de uma câmera para infra-vermelho. Exemplos das imagens observadas observa-se na Figura 58.

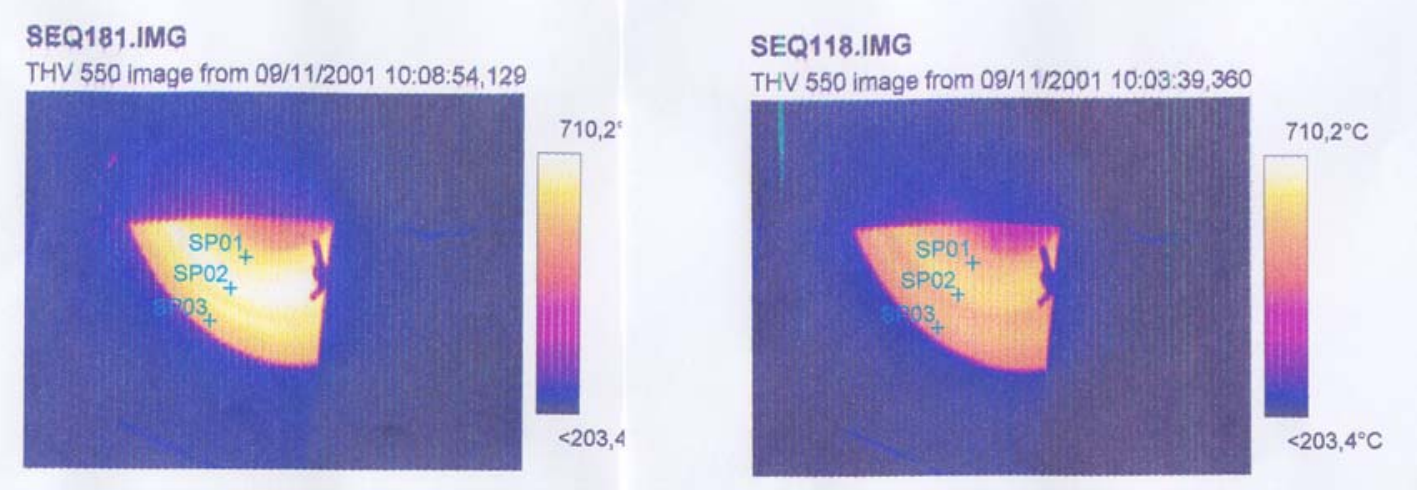

Figura 58 - Imagens da câmera de infra-vermelho de um quadrante do disco de freio no dinamômetro inercial.

A termografia é uma imagem eletrônica produzida e representativa dos padrões térmicos encontrados em uma dada superfície.

TIN (1998) sugere que o uso da termografia no desenvolvimento térmico de veículos, além de mostrar uma imagem dos padrões de calor irradiando por uma superfície, também pode indicar suas variações e os valores de temperatura localizados.

A câmera foi acionada durante toda a realização do ensaio em dinamômetro. Tal equipamento não mede a temperatura diretamente, mas sim a quantidade de radiação infra-vermelha sobre a célula, e a escala de leitura depende da emissividade da superfície e da distância a que a câmera foi posicionada. Os resultados foram armazenados em tempo real e posteriormente descarregados num microcomputador padrão PC e analisados por meio de um software específico.

Tal software permite a visualização de todas as imagens registradas durante o ensaio. Pode-se obter valores de temperaturas sobre qualquer ponto da imagem, traçar áreas ou linhas isotérmicas, delimitar áreas para análise, modificar os padrões 
de cores, corrigir parâmetros, como a emissividade, além de elaboração de gráficos e definição de fotos. 


\section{APLICAÇÃO DO PROGRAMA COMPUTACIONAL}

Foi realizada uma simulação computacional do veículo protótipo estudado. As condições iniciais de frenagem foram definidas considerando o momento em que as temperaturas de estabilização nos discos de freio já tivessem sido atingidas e então aplicada uma frenagem de emergência, até o veículo parar completamente.

Com a finalidade de observar o comportamento do programa computacional e sua validade como ferramenta de análise, foram utilizados valores elevados de temperaturas de estabilização.

A fim de estabilizar o sistema e obter uma melhor resposta, foi dada uma entrada degrau de pressão na simulação em 2 segundos, onde a pressão inicial é nula e a pressão final é de $450.000 \mathrm{~N} / \mathrm{m}^{2}$ (4,5 bar). A pressão final corresponde à máxima pressão para que o veículo não perca a estabilidade com o eixo traseiro na iminência de escorregamento, durante a frenagem. Isto corresponde a um acionamento rápido do pedal de freio com a liberação de 4,5 bar de pressão no circuito do freio de serviço. O tempo de resposta do sistema de freio não foi considerado na simulação.

Ainda em busca de realizar uma análise mais simplificada, os lados do veículo foram considerados simétricos, passando-se a denominar os eixos apenas como dianteiro e traseiro.

As simulações realizadas consideraram diferentes velocidades iniciais de frenagem, temperaturas de estabilização compatíveis com maior ou menor nível de ventilação e fatores de freio constantes e variáveis.

A primeira simulação realizada considera o veículo freando, a partir de uma temperatura de estabilização de $450^{\circ} \mathrm{C}$ no eixo traseiro e $400^{\circ} \mathrm{C}$ no eixo dianteiro, com um fator de freio variável conforme a curva obtida em dinamômetro, na FrasLe, partindo-se de diferentes velocidades iniciais de frenagem até a parada total. 
A Figura 59 mostra as temperaturas atingidas nos discos de freio traseiros, e a influência que o aumento da velocidade inicial tem sobre os níveis de temperatura atingidos. Enquanto o aumento de temperatura a $60 \mathrm{~km} / \mathrm{h}$ é de cerca de $15 \%$ e a 80 $\mathrm{km} / \mathrm{h}$ é de $20 \%$, a $100 \mathrm{~km} / \mathrm{h}$ chega a $40 \%$ de aumento.

Este aumento significativo na temperatura também se reflete na mudança do fator de freio, e como se observa nas Figuras 60 e 61, nesses níveis térmicos tal fator sofre uma redução, o que efetivamente contribui para uma diminuição das forças de frenagem, ilustrada na Figura 62. Na figura 63 é possível também observar-se a variação nos níveis de desaceleração conforme muda a velocidade inicial de frenagem, considerando-se o fator de freio variável durante o processo de frenagem.

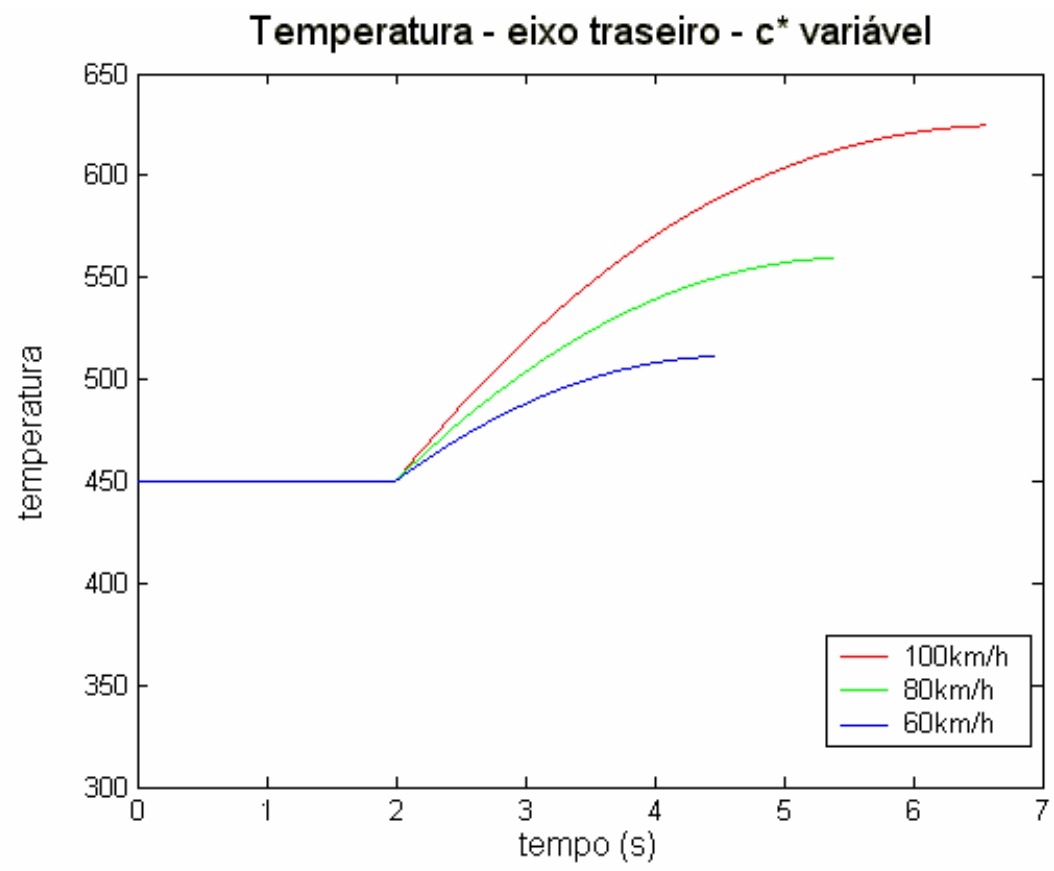

Figura 59 - Temperatura no disco de freio traseiro, com fator de freio variável, para diferentes velocidades iniciais de frenagem. 


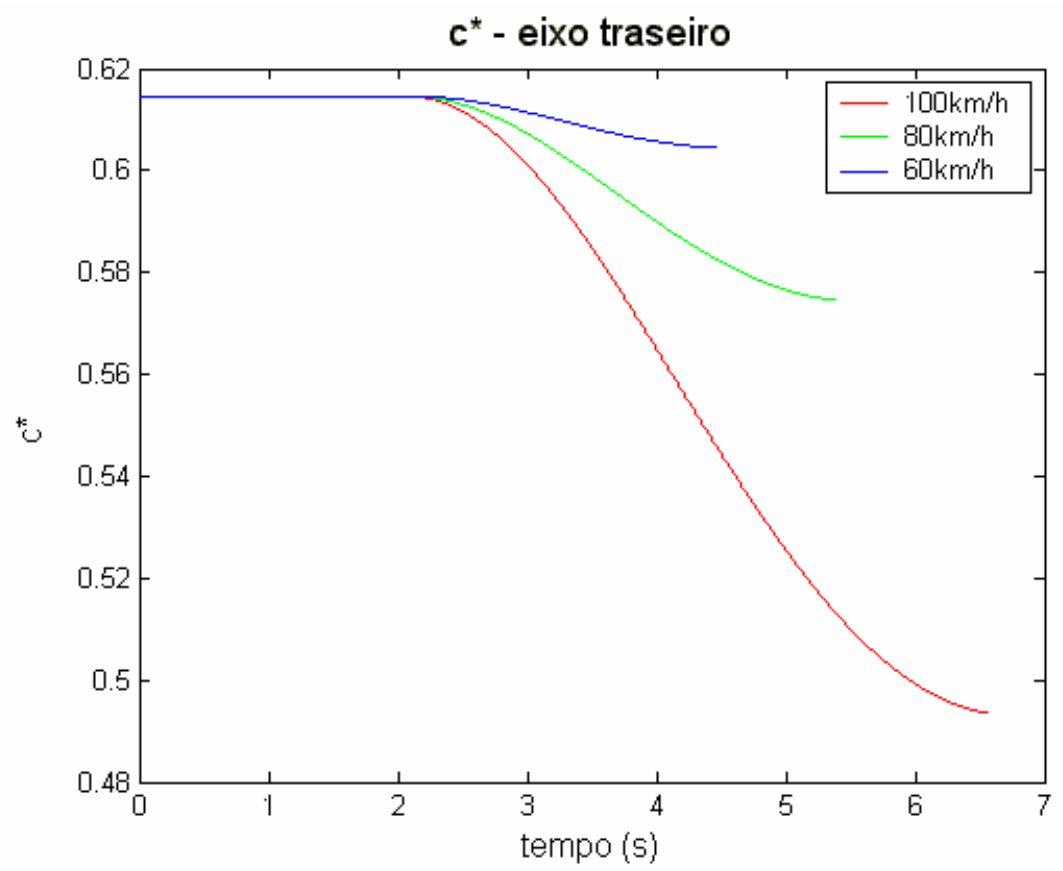

Figura 60 - Fator de freio no eixo traseiro, para diferentes velocidades iniciais de frenagem.

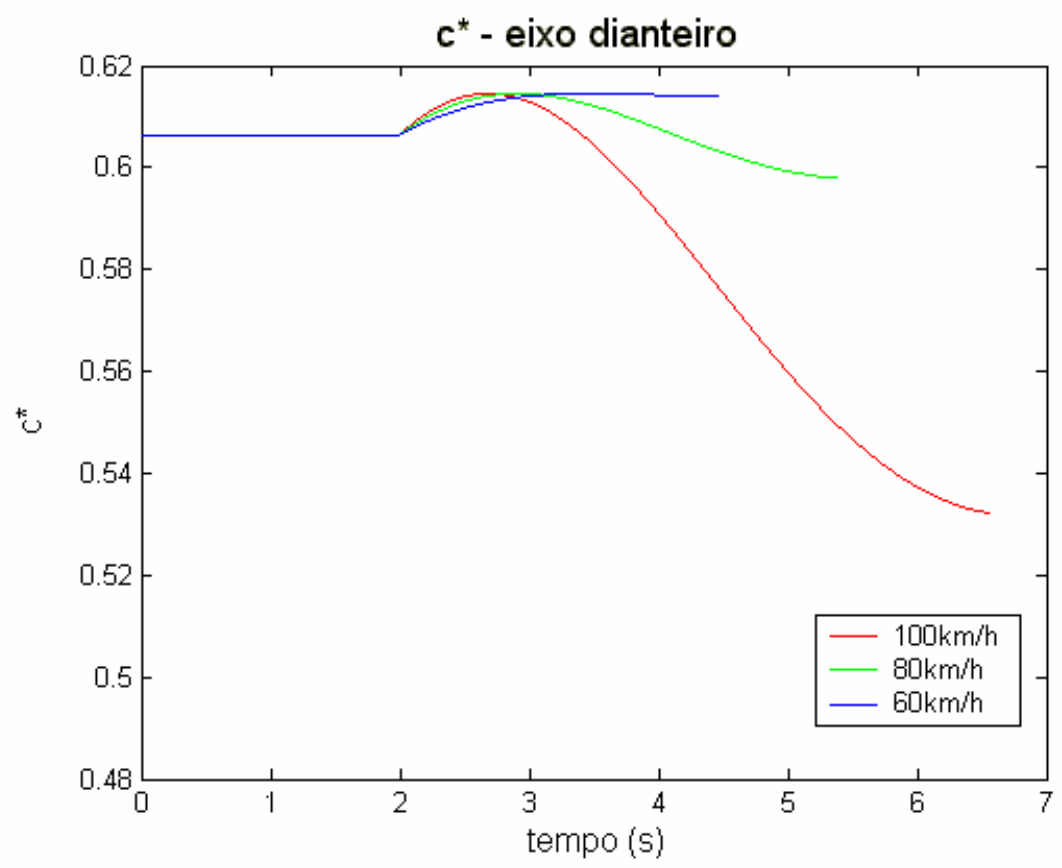

Figura 61 - Fator de freio no eixo dianteiro, para diferentes velocidades iniciais de frenagem. 


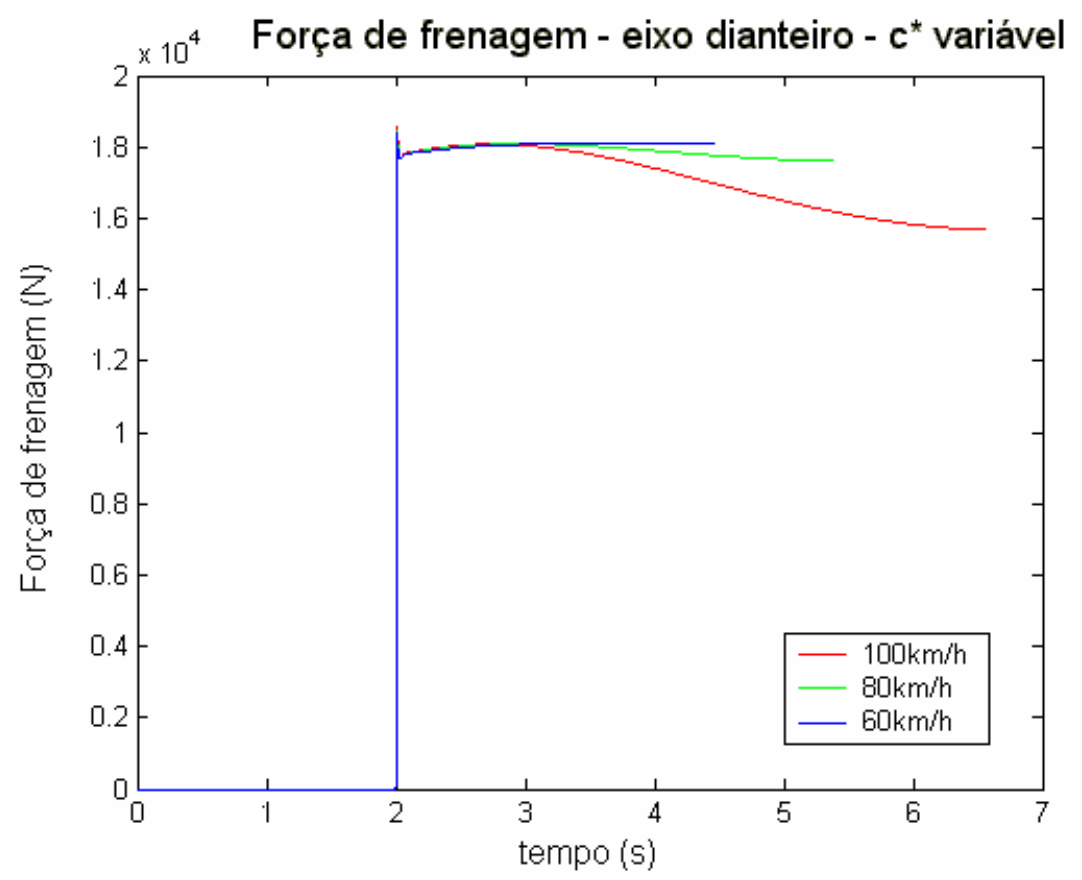

Figura 62 - Força de frenagem no eixo dianteiro, para diferentes velocidades iniciais de frenagem.

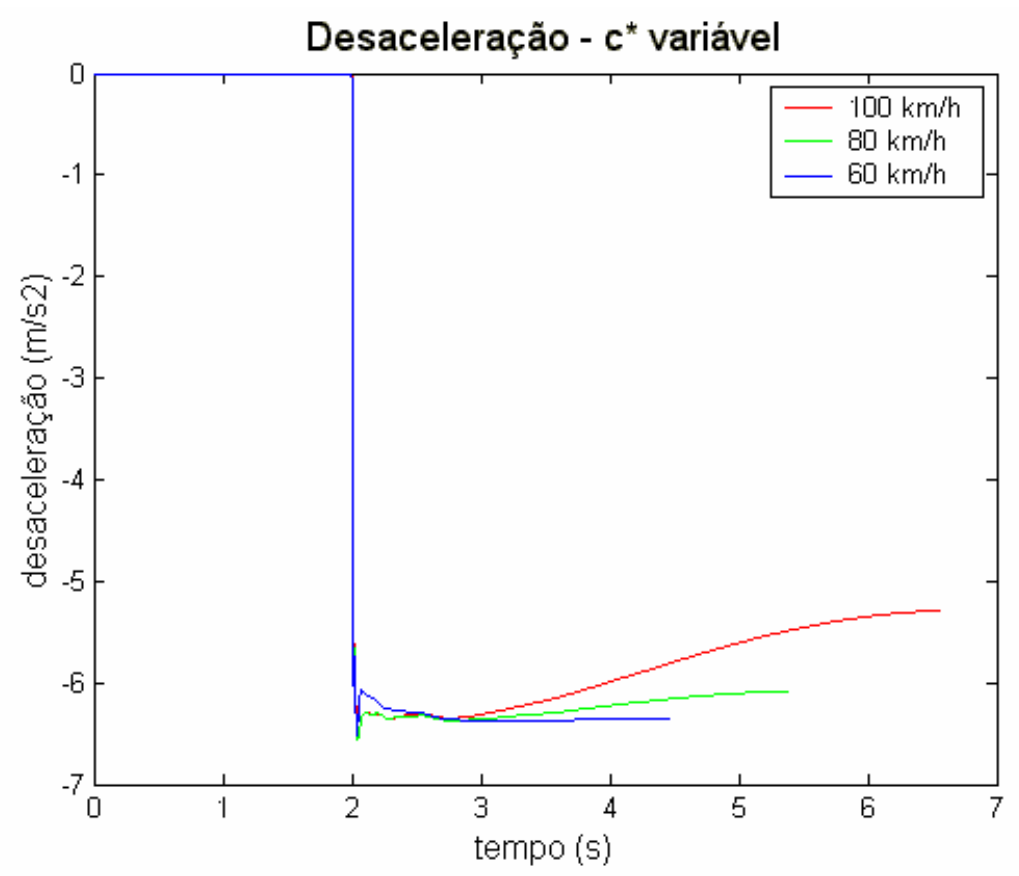

Figura 63 - Desaceleração do veículo para diferentes velocidades iniciais de frenagem. 
O limite de aderência da pista, ou seja, o coeficiente de escorregamento definido para a simulação computacional foi de 0,75 , valor este obtido através de testes na pista de provas. O escorregamento parcial considerado foi de $20 \%$, conforme a curva de aderência dos pneus utilizados, ilustrada na Figura 64. Assim, observa-se na Figura 66 um leve travamento inicial no eixo traseiro, enquanto a Figura 65 mostra um escorregamento parcial muito baixo no eixo dianteiro.

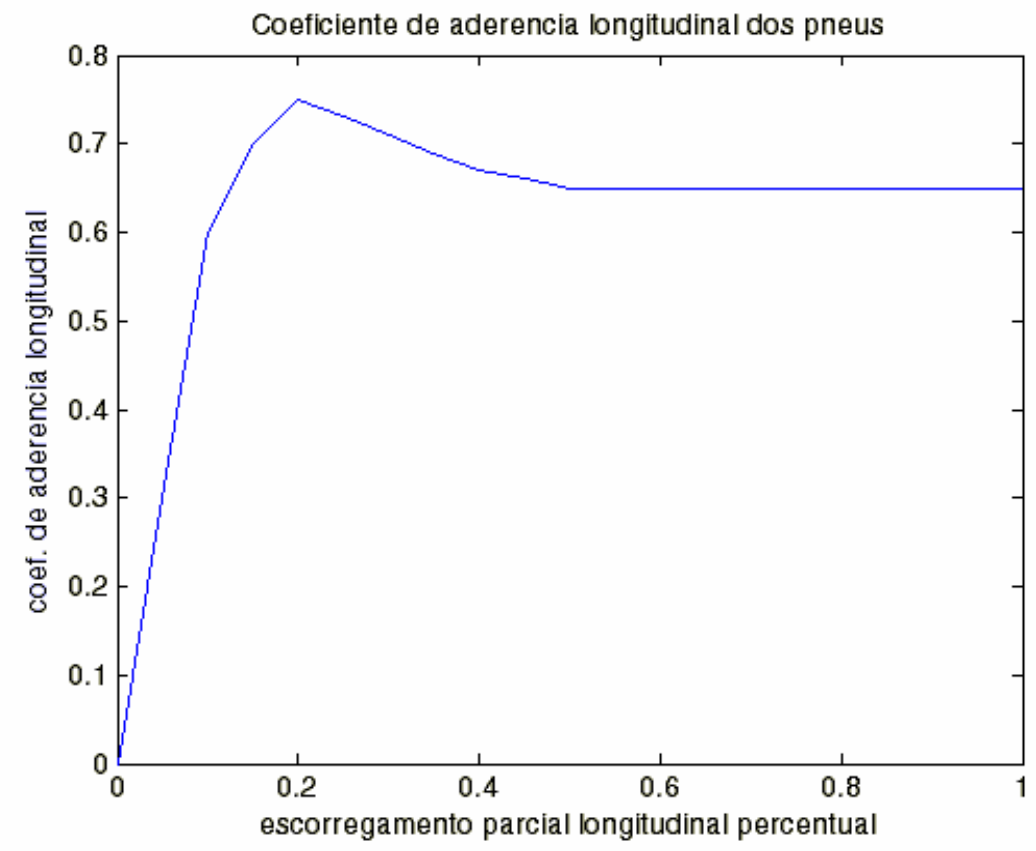

Figura 64 - Coeficiente de aderência dos pneus

As oscilações observadas na Figura 66 são maiores que as da Figura 65 devido à transferência de parte da força normal nos pneus traseiros para os dianteiros.

As freqüências destas oscilações são as características da suspensão nas direções vertical e de arfagem. As amplitudes estão relacionadas com a eficiência dos amortecedores. Desta forma, estes gráficos também podem ser usados para a avaliação da suspensão durante a frenagem do veículo. 


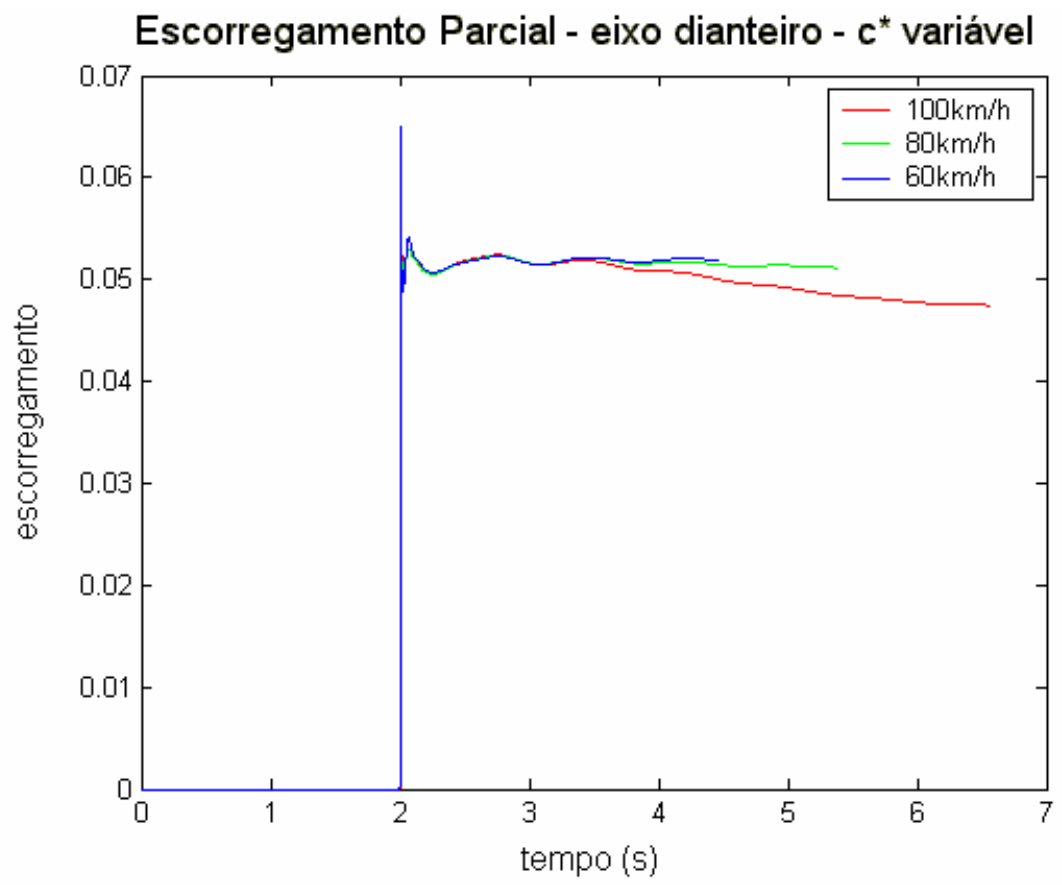

Figura 65 - Escorregamento parcial do eixo dianteiro, para diferentes velocidades iniciais de frenagem.

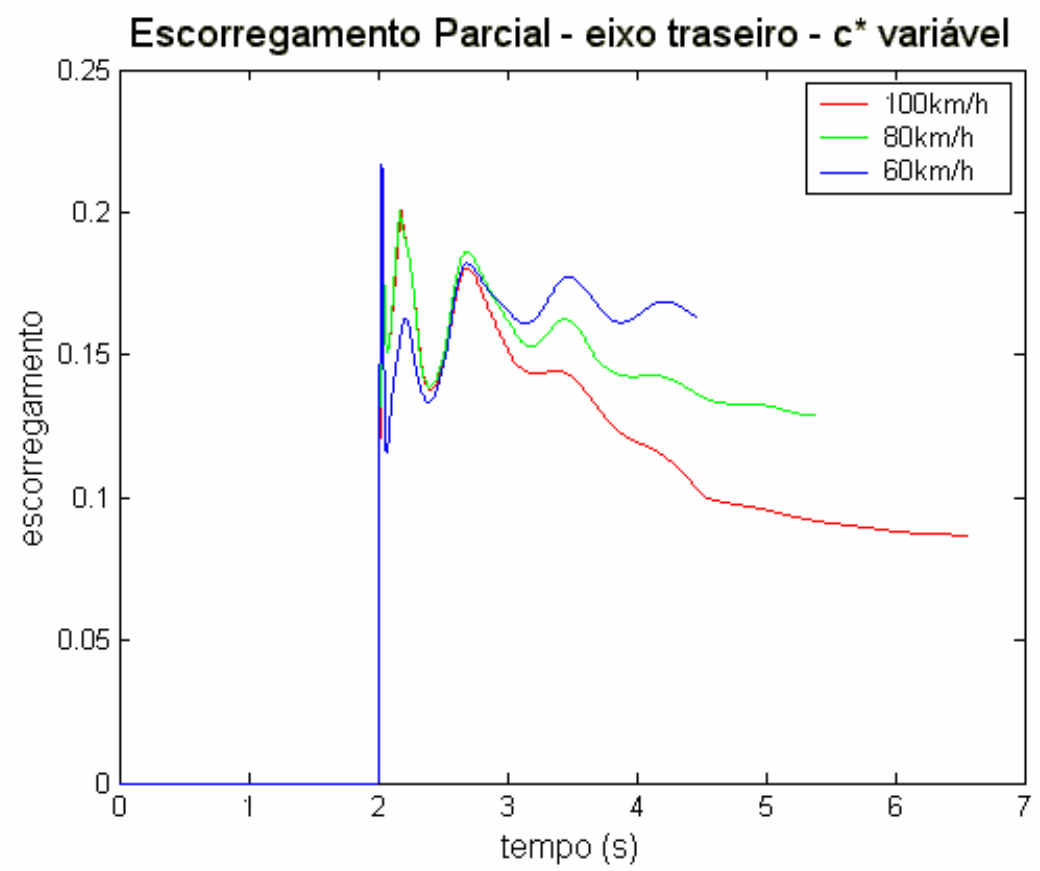

Figura 66 - Escorregamento parcial do eixo traseiro, para diferentes velocidades iniciais de frenagem. 
Sendo a aderência máxima dos pneus de 0,75 na simulação, se observa na Figura 67 e 68 que enquanto o eixo traseiro está próximo deste limite, o eixo dianteiro fica muito abaixo deste patamar. Esta diferença significativa entre os eixos dianteiro e traseiro reflete o incorreto balanceamento do veículo, o que implica em uma utilização desproporcional das forças de frenagem.

Isto diminui a eficiência de frenagem e pode desestabilizar o veículo com o travamento de suas rodas traseiras em uma situação de emergência.

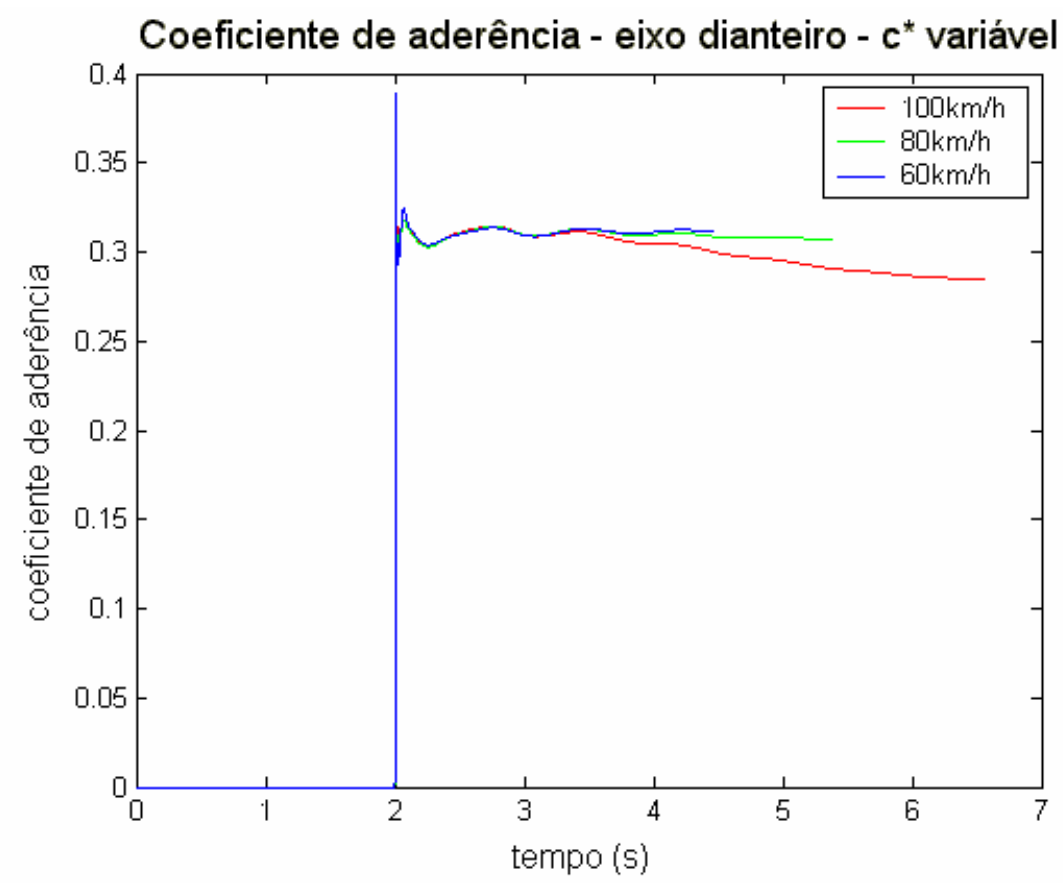

Figura 67 - Coeficiente de aderência no eixo dianteiro, para diferentes velocidades iniciais de frenagem. 


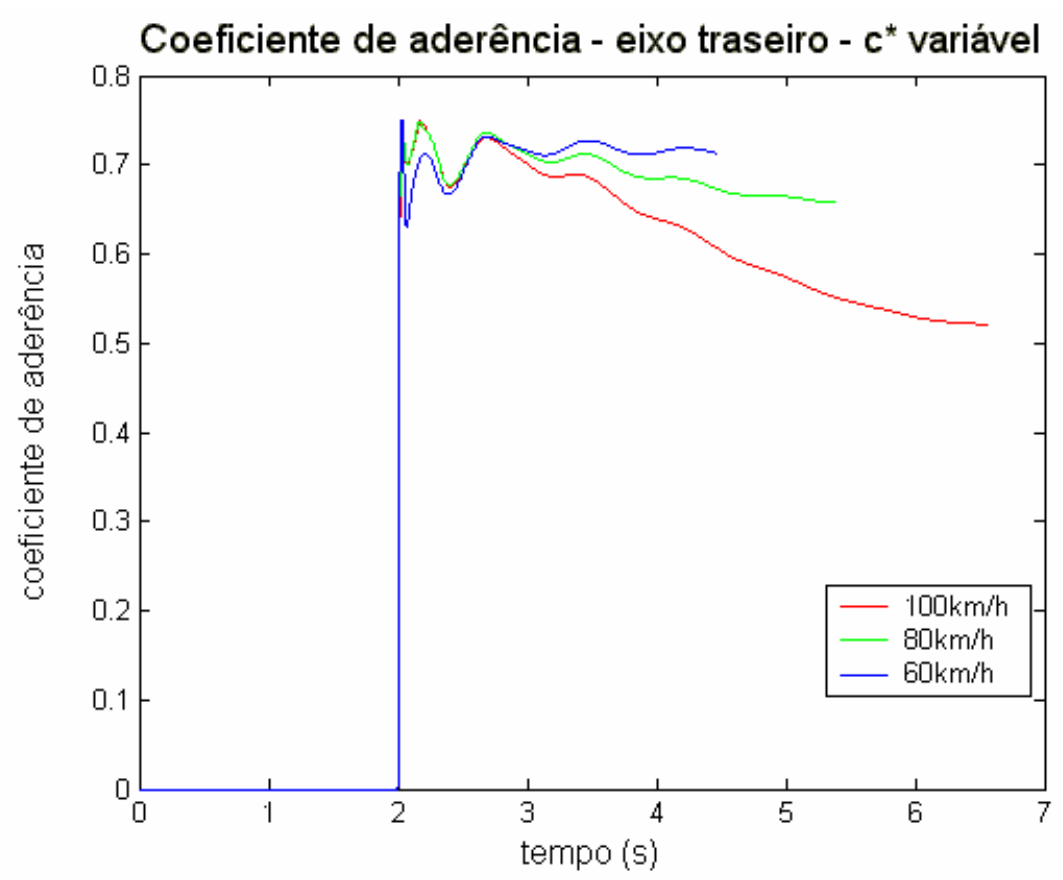

Figura 68 - Coeficiente de aderência no eixo traseiro, para diferentes velocidades iniciais de frenagem.

A segunda simulação considera o veículo freando a partir de uma velocidade inicial de $60 \mathrm{~km} / \mathrm{h}$, com uma temperatura de estabilização de $450^{\circ} \mathrm{C}$ no eixo traseiro e $400^{\circ} \mathrm{C}$ no eixo dianteiro, e para diferentes fatores de freio. As Figuras 69 e 70 mostram as variações na força de frenagem considerando o fator de freio constante de 0,6, 0,65 ou variável conforme a curva obtida em dinamômetro.

Nas Figuras 71 e 72 observa-se as variações no escorregamento parcial e nas Figuras 73 e 74 o coeficiente de aderência utilizado no eixo dianteiro e traseiro, respectivamente.

A figura 74 mostra que para um fator de freio de 0,65 , o escorregamento parcial da roda ultrapassaria 0,2 (20\%) o que levaria ao travamento das rodas do eixo traseiro. Isto pode provocar a perda da estabilidade do veículo durante a frenagem.

No entanto, o programa de simulação computacional mantém a roda em $20 \%$ de escorregamento no máximo, fazendo o papel de um ABS. 


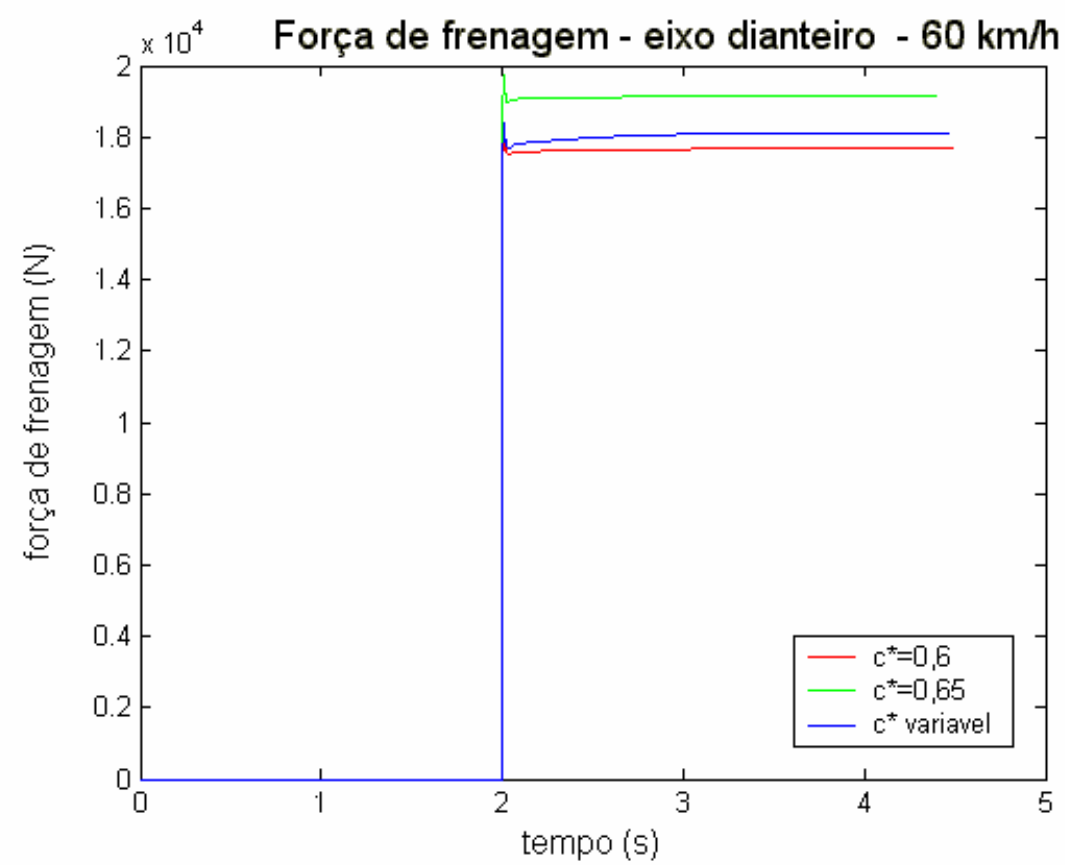

Figura 69 - Força de frenagem no eixo dianteiro, considerando diferentes fatores de freio para a velocidade inicial de frenagem de $60 \mathrm{~km} / \mathrm{h}$.

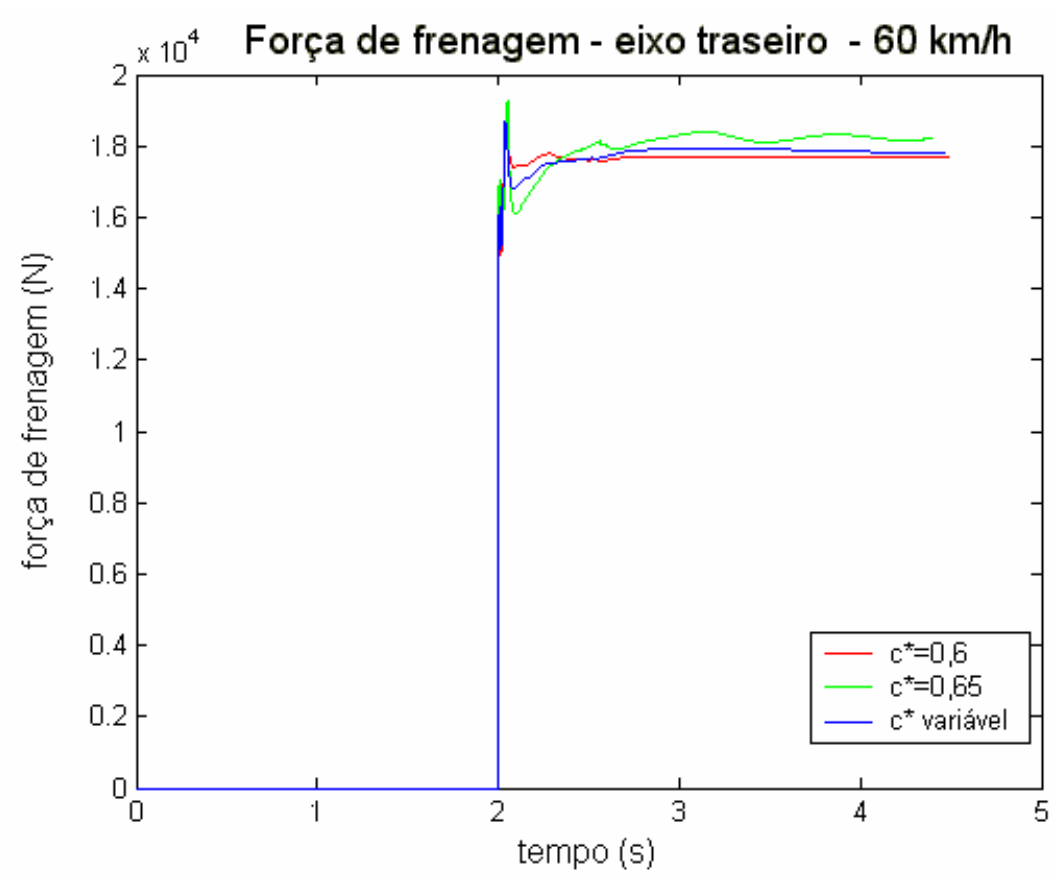

Figura 70 - Força de frenagem no eixo traseiro, considerando diferentes fatores de freio para a velocidade inicial de frenagem de $60 \mathrm{~km} / \mathrm{h}$. 


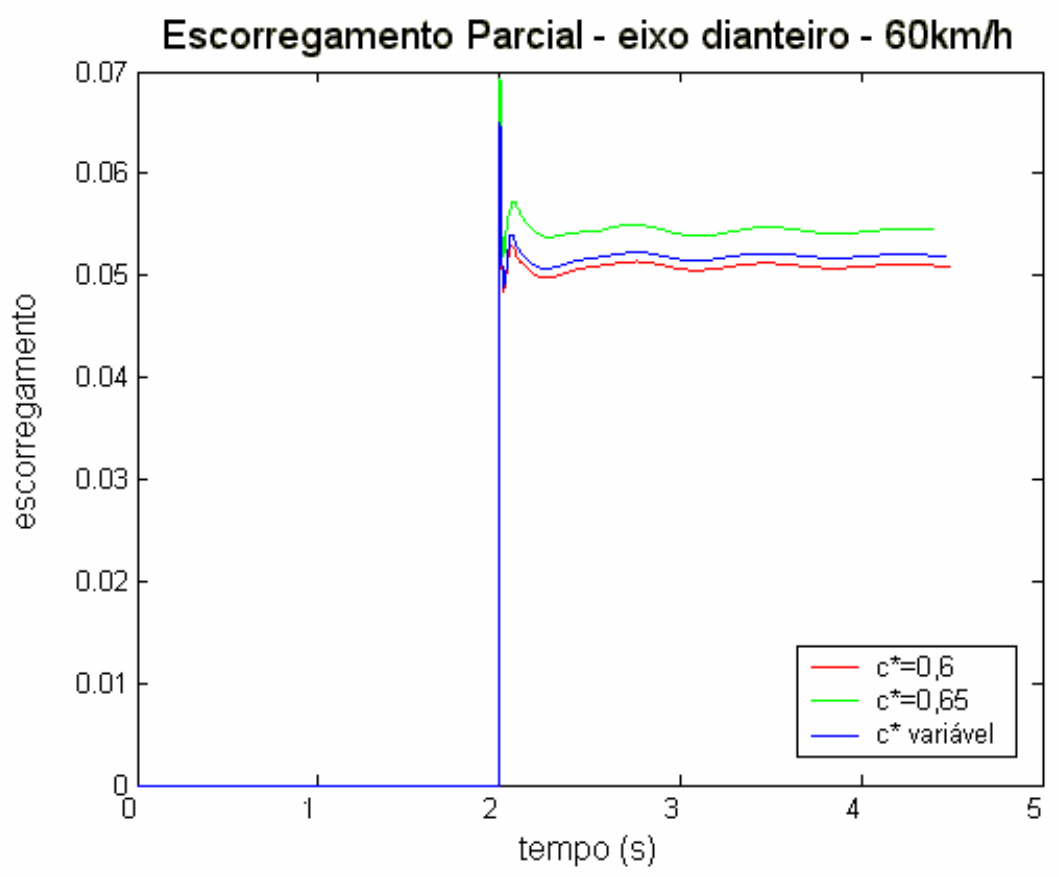

Figura 71 - Escorregamento parcial do eixo dianteiro, considerando diferentes fatores de freio para a velocidade inicial de frenagem de $60 \mathrm{~km} / \mathrm{h}$.

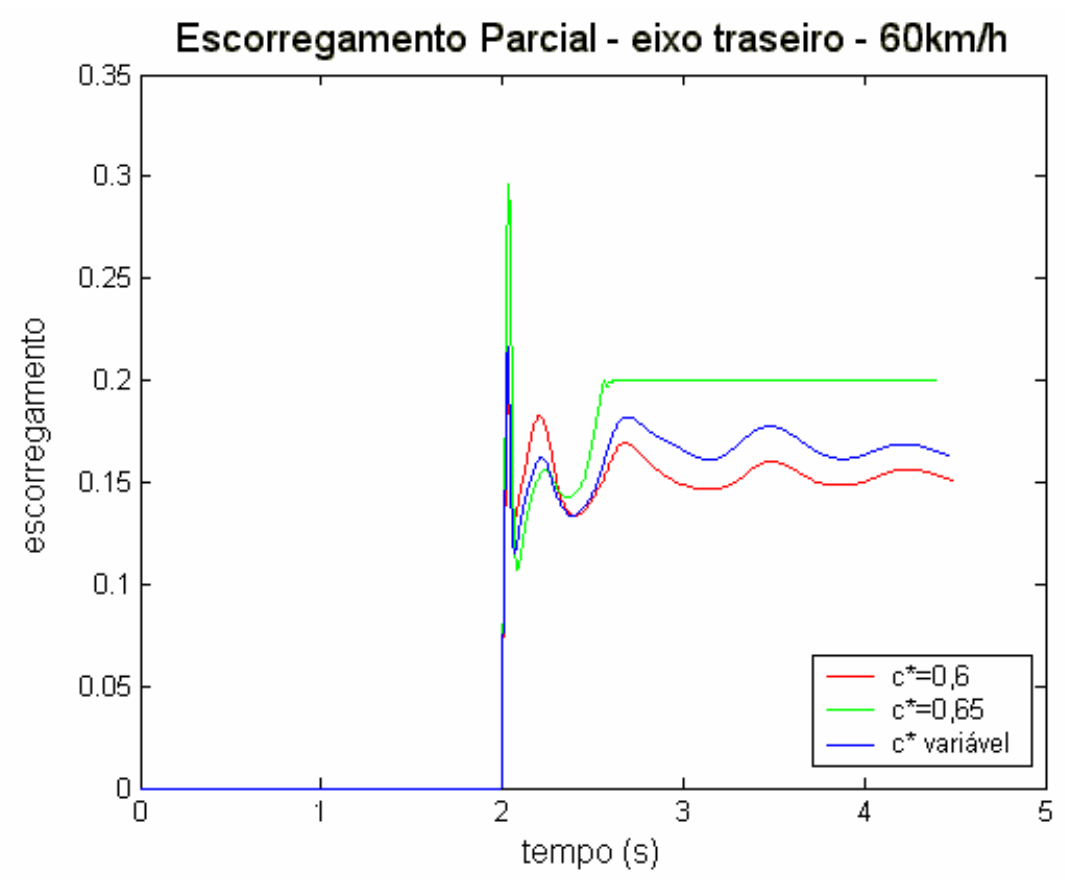

Figura 72 - Escorregamento parcial do eixo traseiro, considerando diferentes fatores de freio para a velocidade inicial de frenagem de $60 \mathrm{~km} / \mathrm{h}$. 


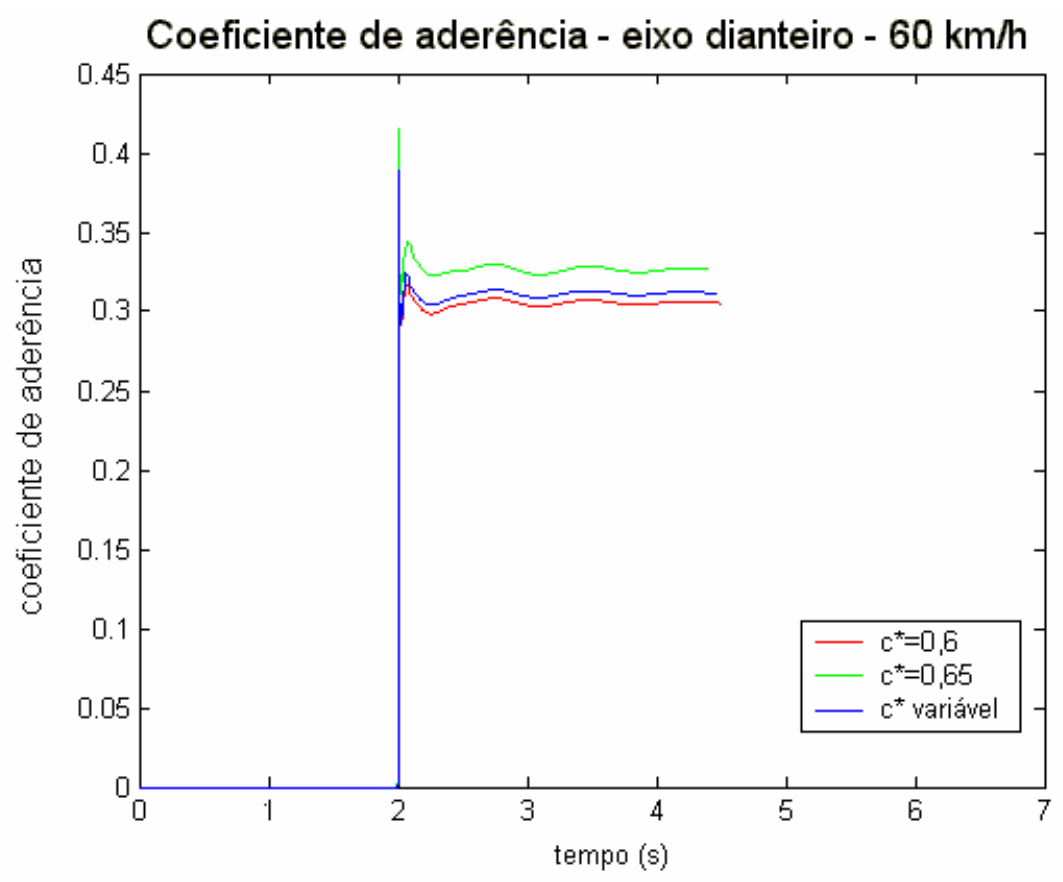

Figura 73 - Coeficiente de aderência no eixo dianteiro, considerando diferentes fatores de freio para a velocidade inicial de frenagem de $60 \mathrm{~km} / \mathrm{h}$.

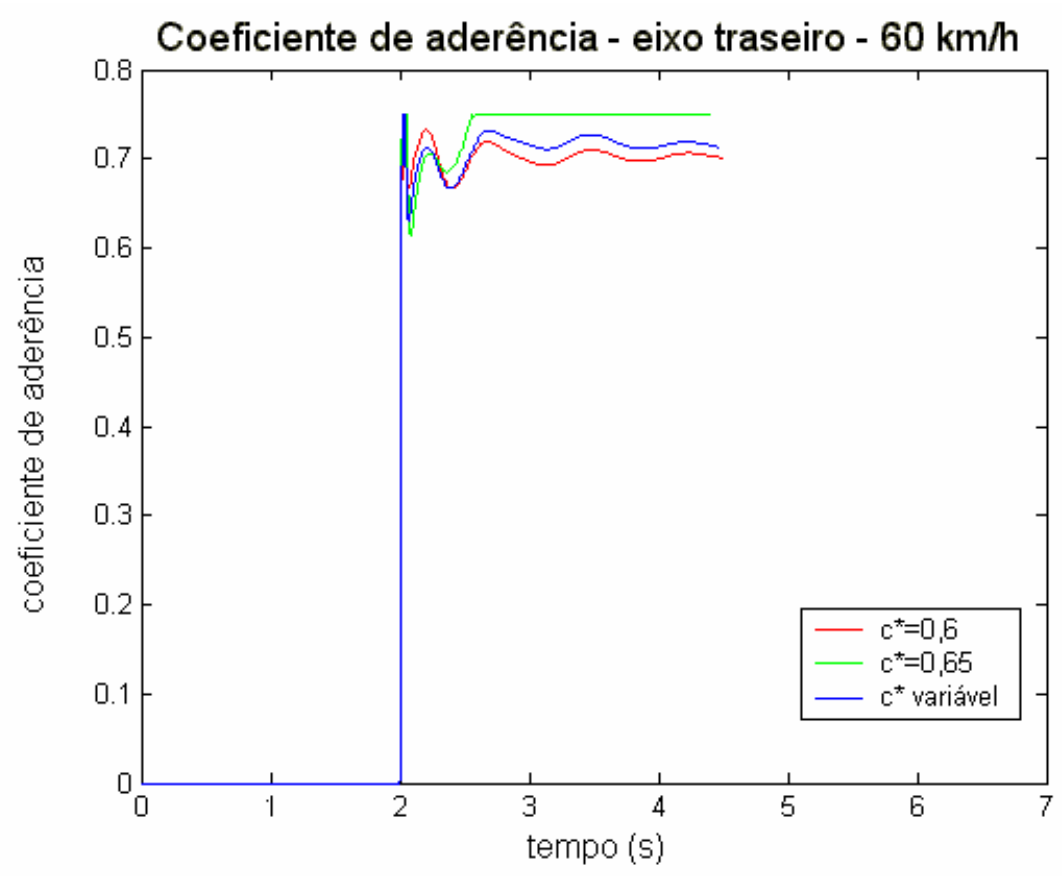

Figura 74 - Coeficiente de aderência no eixo traseiro, considerando diferentes fatores de freio para a velocidade inicial de frenagem de $60 \mathrm{~km} / \mathrm{h}$. 
Na terceira simulação o veículo foi considerado freando a partir de uma velocidade inicial de $80 \mathrm{~km} / \mathrm{h}$, com uma temperatura de estabilização de $450^{\circ} \mathrm{C}$ no eixo traseiro e $400^{\circ} \mathrm{C}$ no eixo dianteiro, e para um fator de freio constante $(0,6)$ ou variável conforme a curva obtida em dinamômetro. As Figuras 75 e 76 mostram a variação no comportamento do fator de freio com o aumento da temperatura. Observa-se que considerar o fator de freio constante em uma análise pode mascarar suas reais alterações e conseqüentemente não se avaliar uma possível redução das forças de frenagem, como ilustra a Figura 77.

Na Figura 78 observa-se que ao utilizar um fator de freio constante também seria considerada uma melhor utilização da força de frenagem do que realmente ocorre com o fator de freio variável. A Figura 79 ilustra ainda a variação no coeficiente de aderência para as diferentes condições de fator de freio.

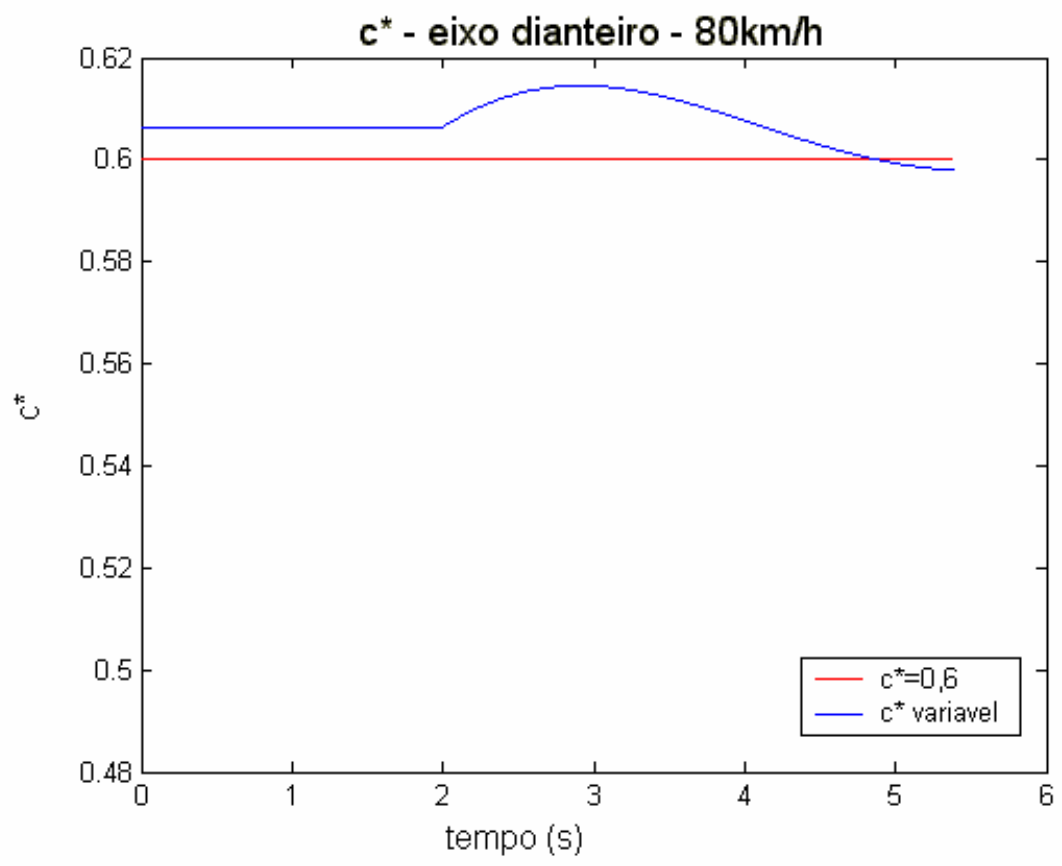

Figura 75 - Fator de freio no eixo dianteiro, para a velocidade inicial de frenagem de $80 \mathrm{~km} / \mathrm{h}$. 


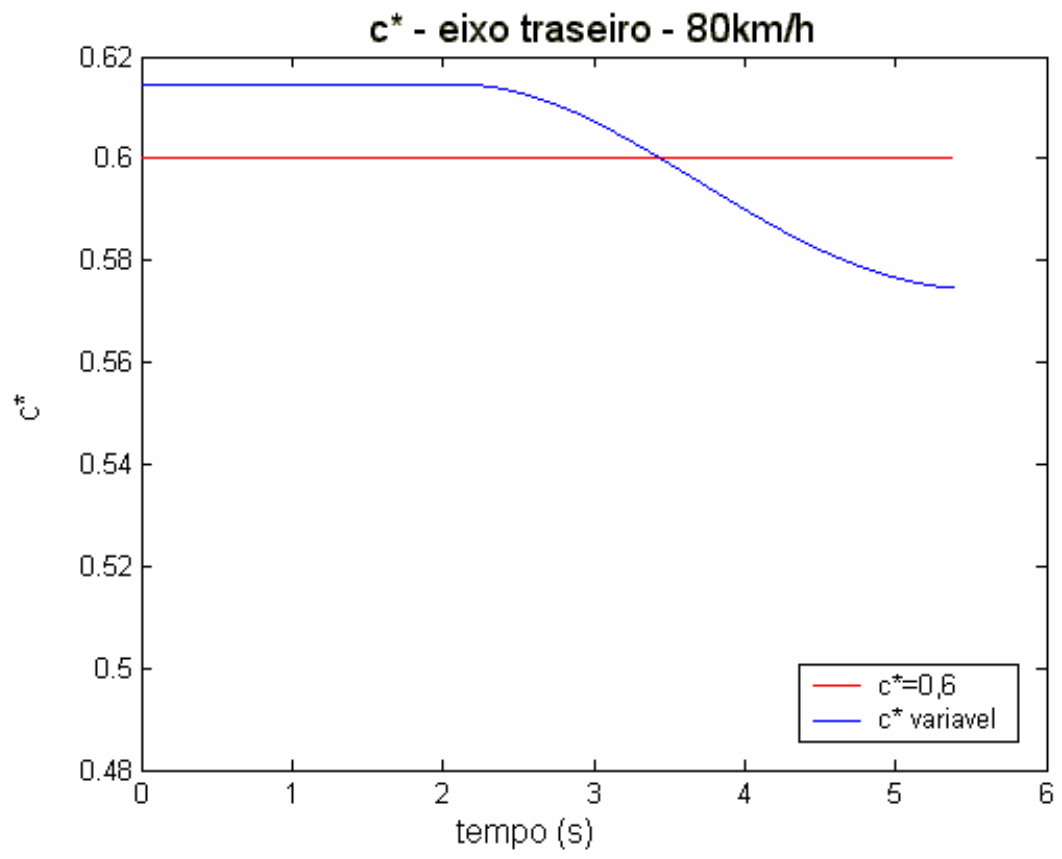

Figura 76 - Fator de freio no eixo dianteiro, para a velocidade inicial de frenagem de $80 \mathrm{~km} / \mathrm{h}$.

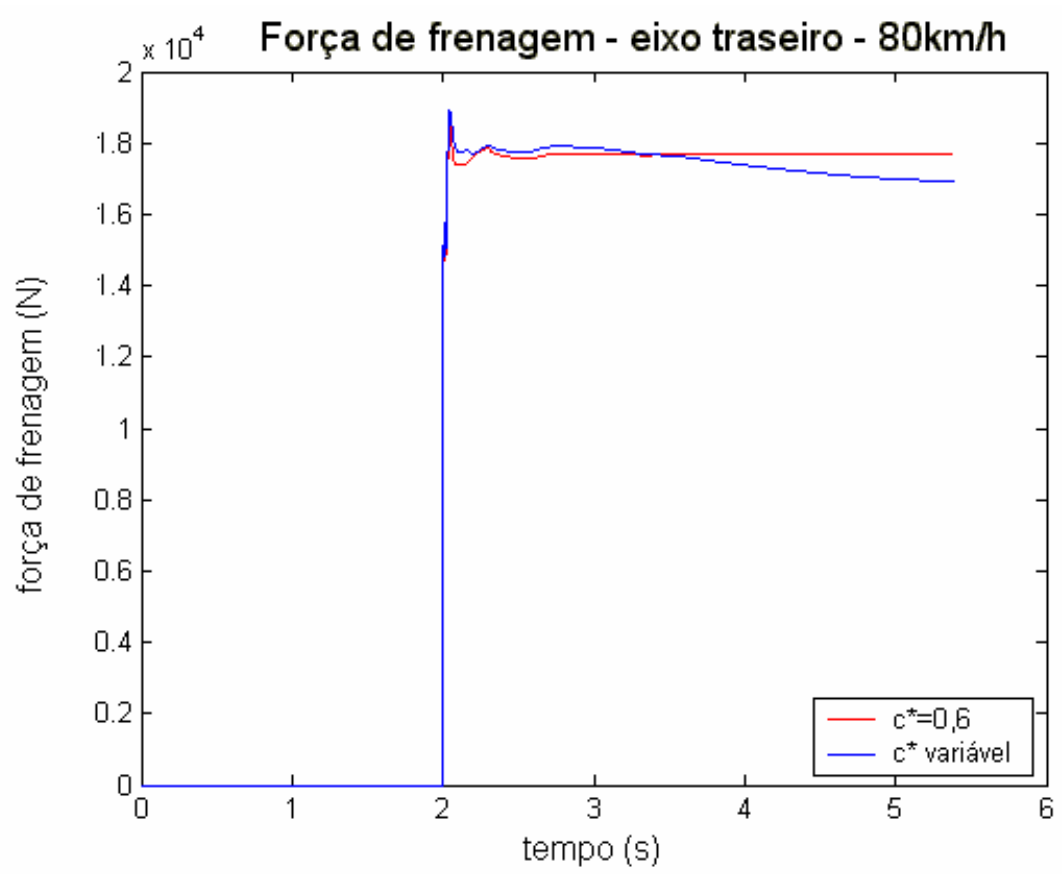

Figura 77 - Força de frenagem no eixo traseiro, considerando diferentes fatores de freio para a velocidade inicial de frenagem de $80 \mathrm{~km} / \mathrm{h}$. 


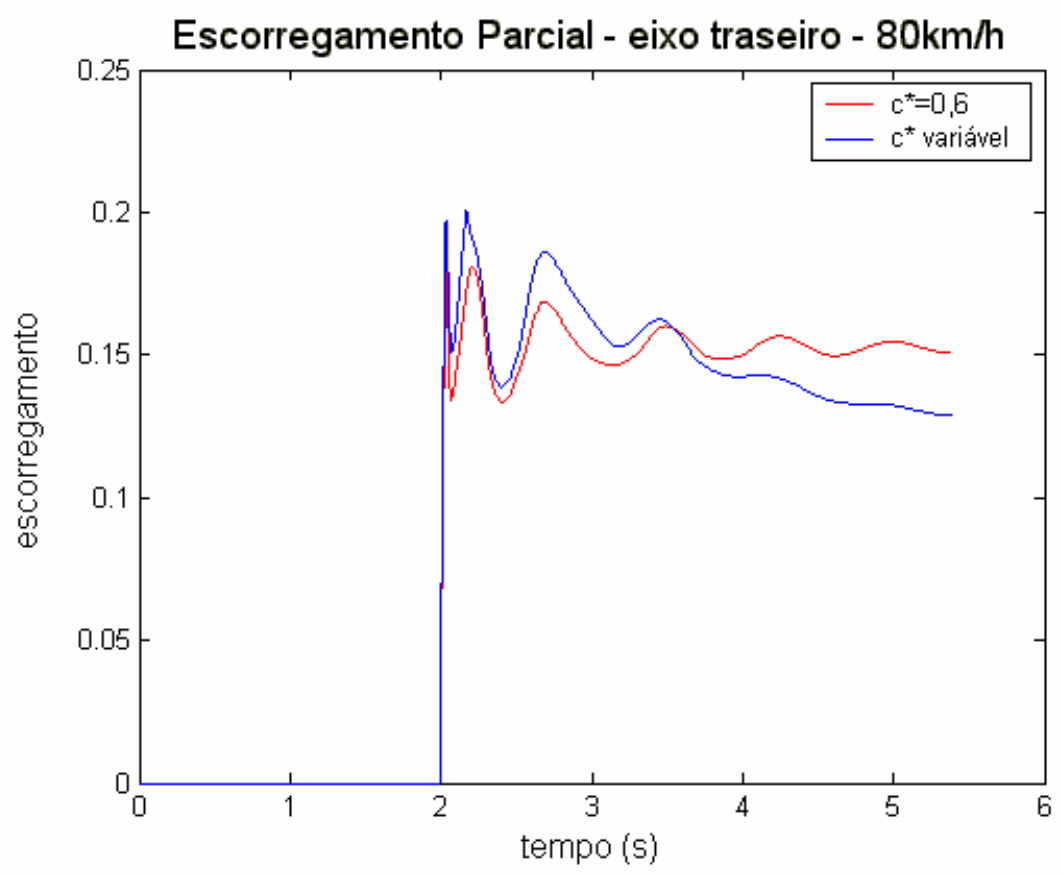

Figura 78 - Escorregamento parcial do eixo traseiro, considerando diferentes fatores de freio para a velocidade inicial de frenagem de $80 \mathrm{~km} / \mathrm{h}$.

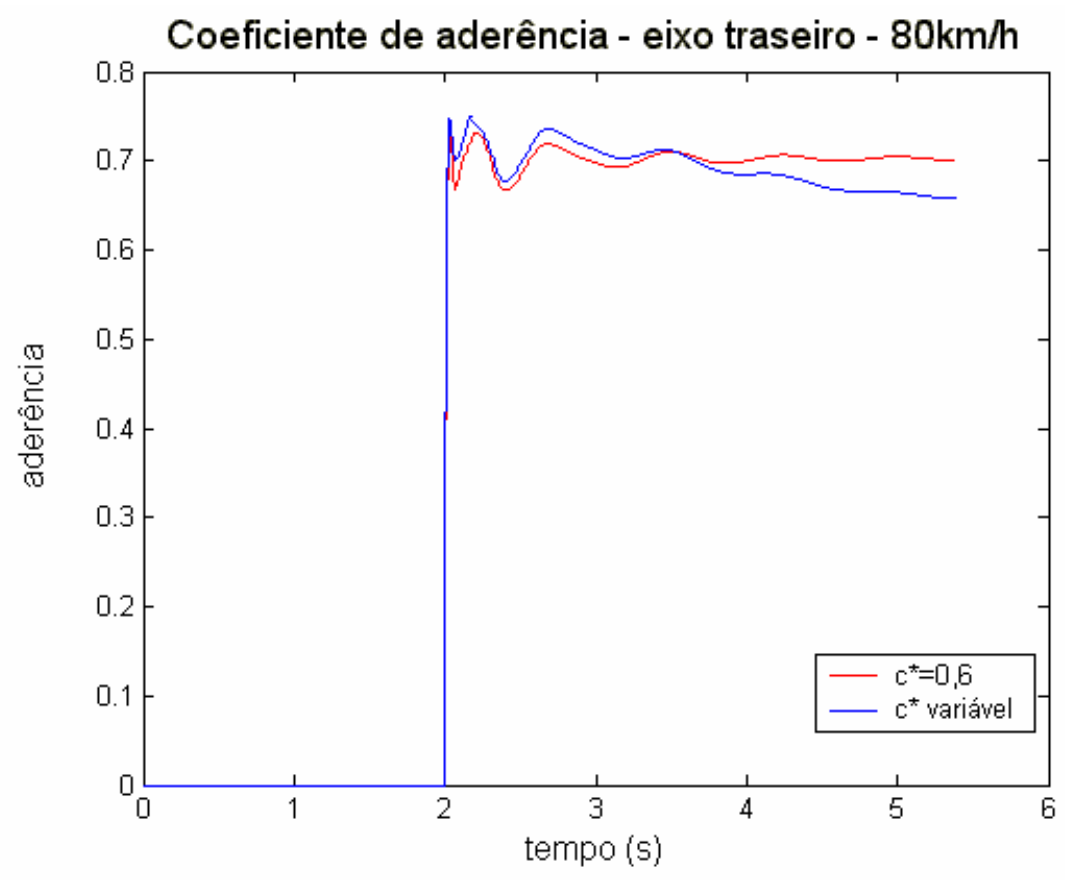

Figura 79 - Coeficiente de aderência no eixo traseiro, considerando diferentes fatores de freio para a velocidade inicial de frenagem de $80 \mathrm{~km} / \mathrm{h}$. 
A quarta simulação considera o veículo freando a partir de uma velocidade inicial de $100 \mathrm{~km} / \mathrm{h}$, com uma temperatura de estabilização de $450^{\circ} \mathrm{C}$ no eixo traseiro e $400^{\circ} \mathrm{C}$ no eixo dianteiro, e para um fator de freio constante $(0,6)$ ou variável conforme a curva obtida em dinamômetro. Observa-se nas Figuras 80 e 81 uma queda no fator de freio bastante significativa com o aumento da temperatura, o que conseqüentemente produz forças de frenagens menores, como ilustram as Figuras 82 e 83.

As Figuras 84 e 85 mostram respectivamente as variações no escorregamento parcial e no coeficiente de aderência.

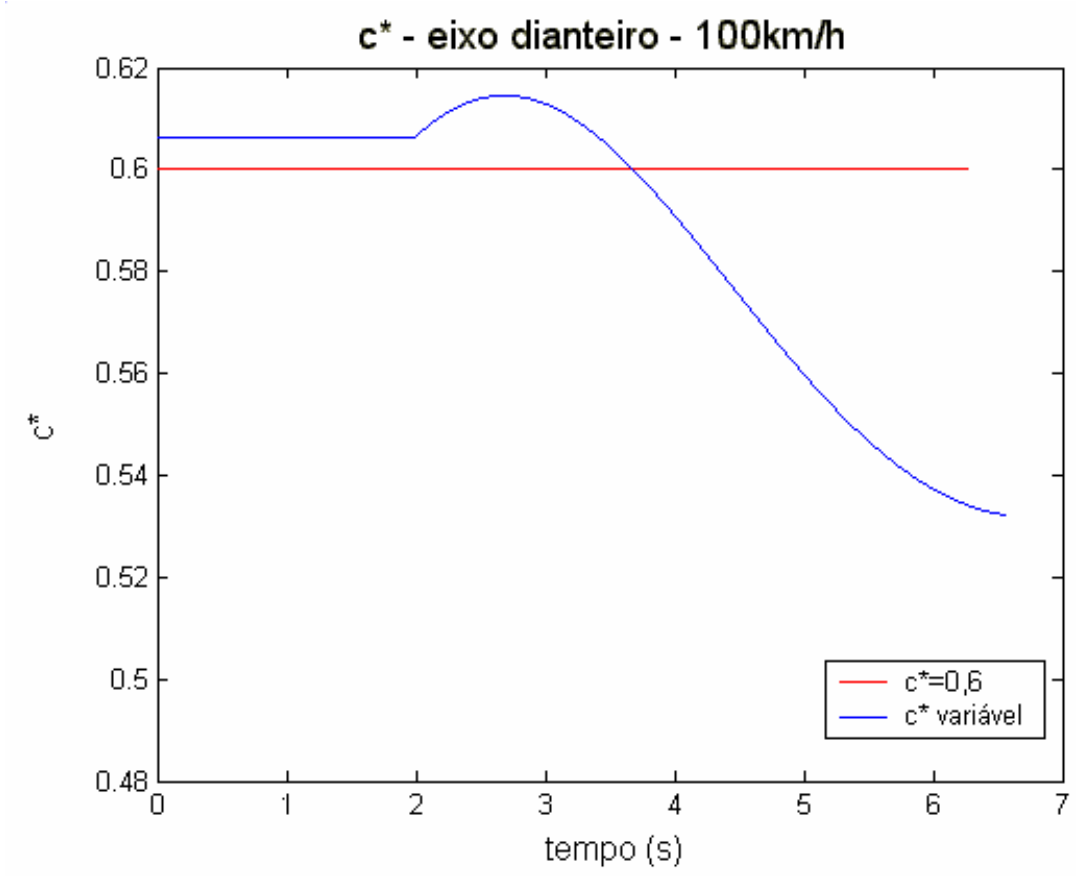

Figura 80 - Fator de freio no eixo dianteiro, para a velocidade inicial de frenagem de $100 \mathrm{~km} / \mathrm{h}$. 


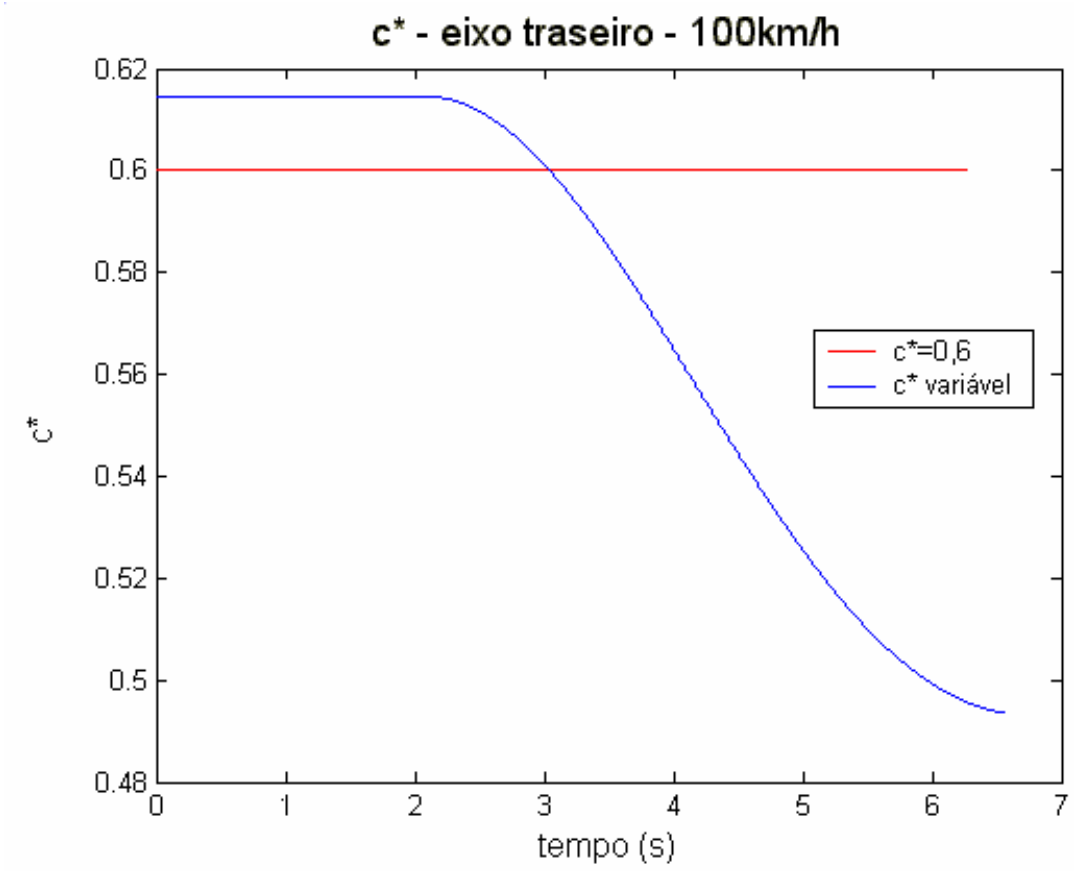

Figura 81 - Fator de freio no eixo traseiro, para a velocidade inicial de frenagem de $100 \mathrm{~km} / \mathrm{h}$.

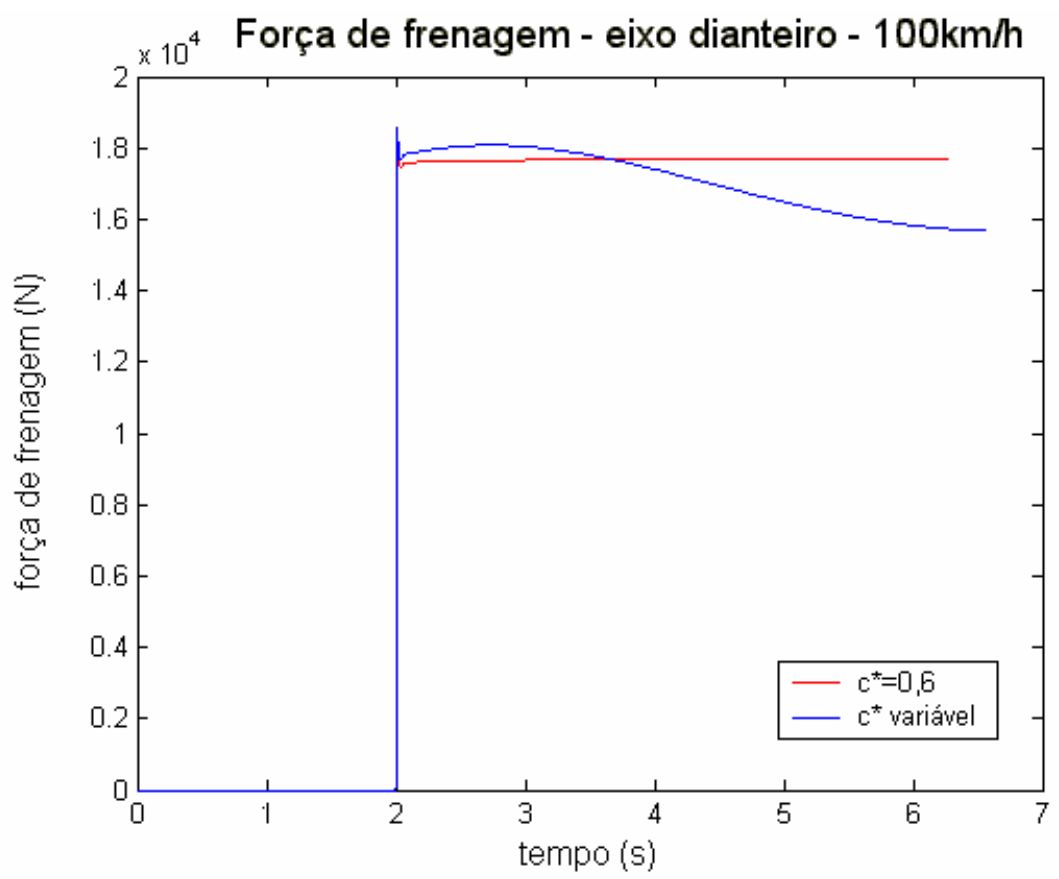

Figura 82 - Força de frenagem no eixo dianteiro, considerando diferentes fatores de freio para a velocidade inicial de frenagem de $100 \mathrm{~km} / \mathrm{h}$. 


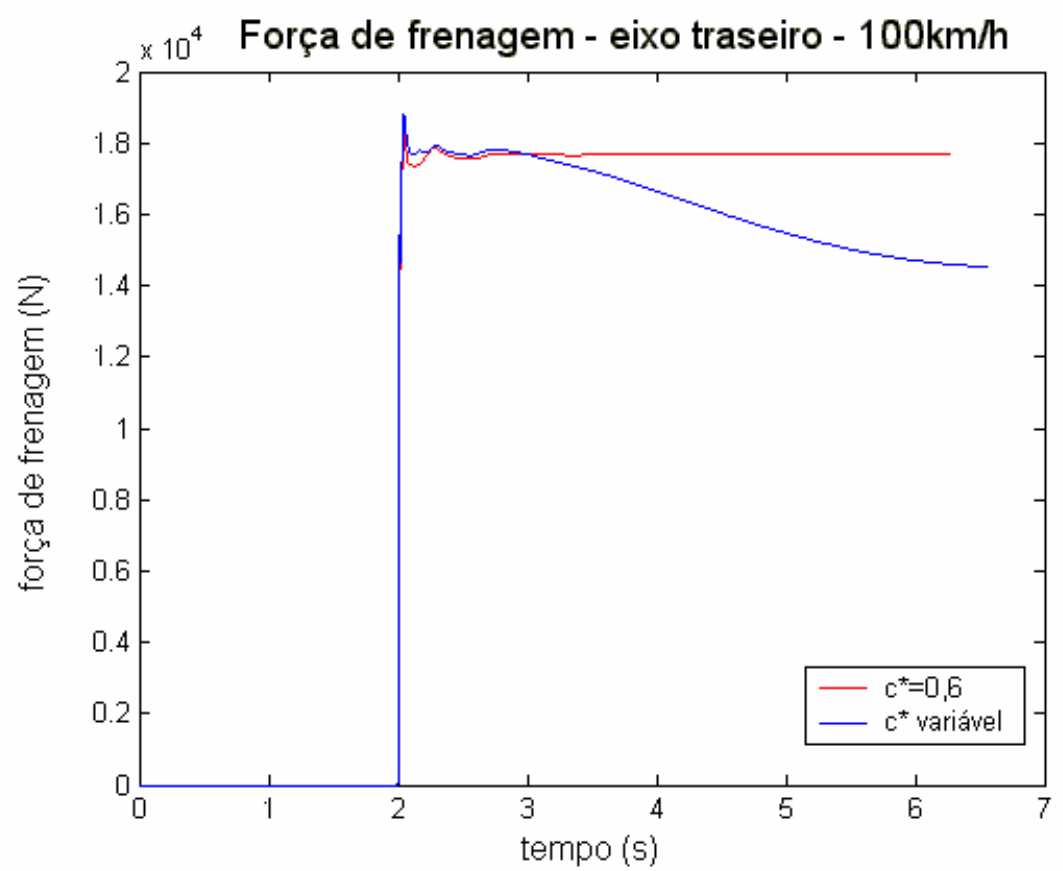

Figura 83 - Força de frenagem no eixo traseiro, considerando diferentes fatores de freio para a velocidade inicial de frenagem de $100 \mathrm{~km} / \mathrm{h}$.

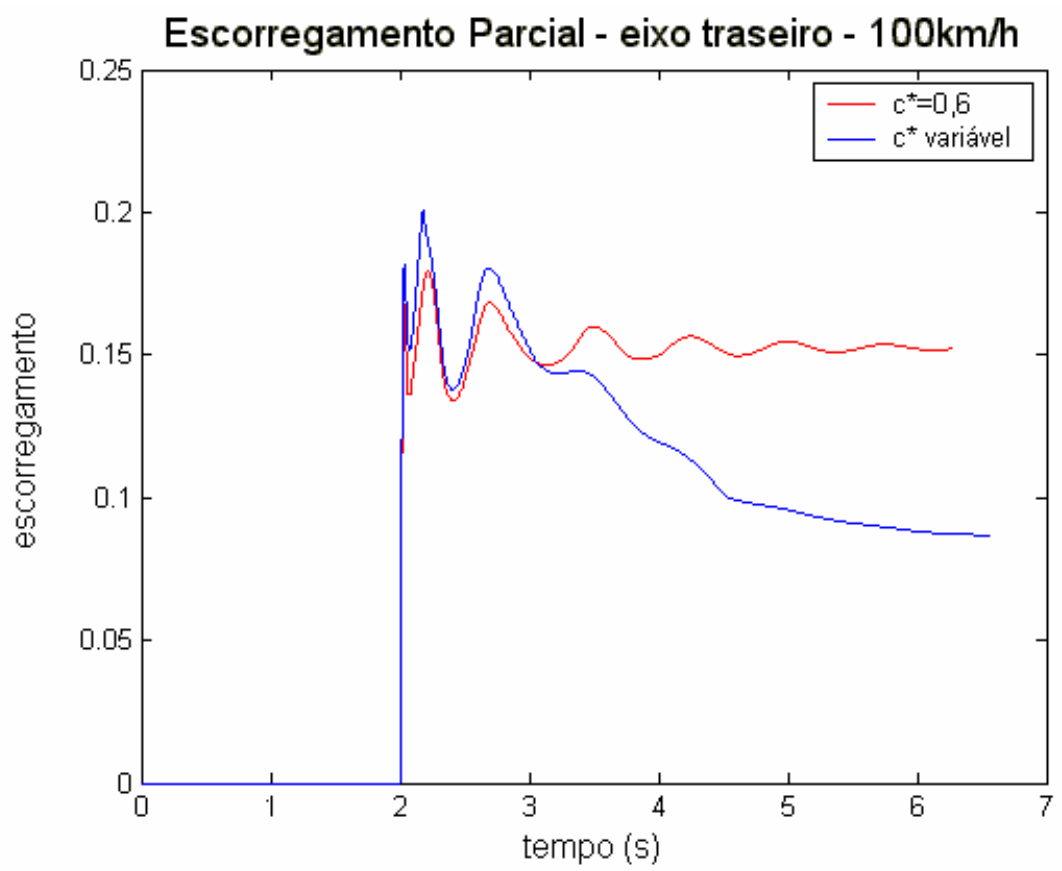

Figura 84 - Escorregamento parcial do eixo traseiro, considerando diferentes fatores de freio para a velocidade inicial de frenagem de $100 \mathrm{~km} / \mathrm{h}$. 


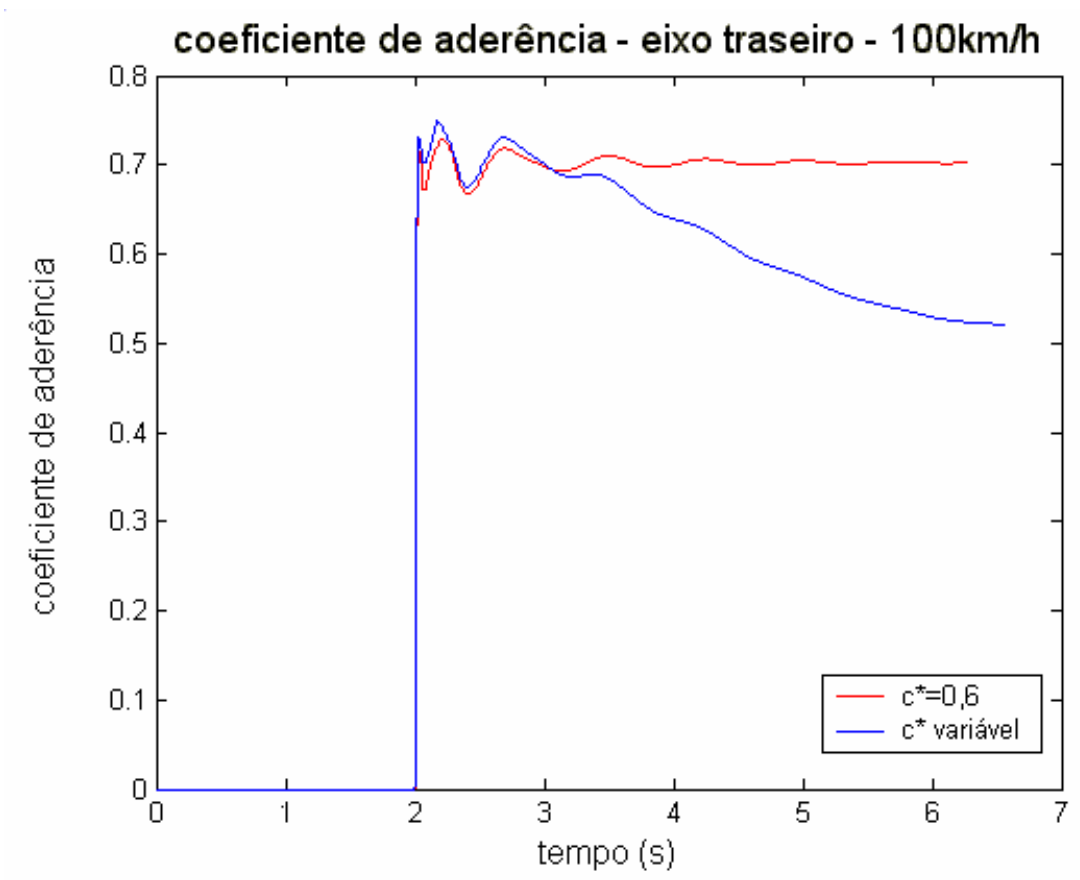

Figura 85 - Coeficiente de aderência no eixo traseiro, considerando diferentes fatores de freio para a velocidade inicial de frenagem de $100 \mathrm{~km} / \mathrm{h}$.

A quinta simulação considera o veículo freando a partir de diferentes velocidades iniciais (60 km/h, $80 \mathrm{~km} / \mathrm{h}$ e $100 \mathrm{~km} / \mathrm{h})$, a partir de uma temperatura de estabilização de $450^{\circ} \mathrm{C}$ no eixo traseiro e $400^{\circ} \mathrm{C}$ no eixo dianteiro, para um fator de freio variável. Foi ainda avaliada a mesma simulação, apenas modificando as temperaturas de estabilização para $350^{\circ} \mathrm{C}$ no eixo traseiro e $300^{\circ} \mathrm{C}$ no eixo dianteiro, redução esta proporcional à instalação de um equipamento de ventilação forçada no sistema de freio.

As Figuras 86 e 87 mostram que com a ventilação forçada, os níveis térmicos atingidos no final da frenagem são bem inferiores aos atingidos normalmente.

Na Figura 88 observa-se que com a presença da ventilação forçada no eixo dianteiro ocorre um aumento mais acentuado no fator de freio, embora se mantenha em níveis inferiores à condição sem ventilação. Já no eixo traseiro, como mostra a Figura 89, ocorre uma inversão do fator de freio, que com a presença da ventilação forçada passa a recuperar-se e conseqüentemente proporciona uma maior força de frenagem. 


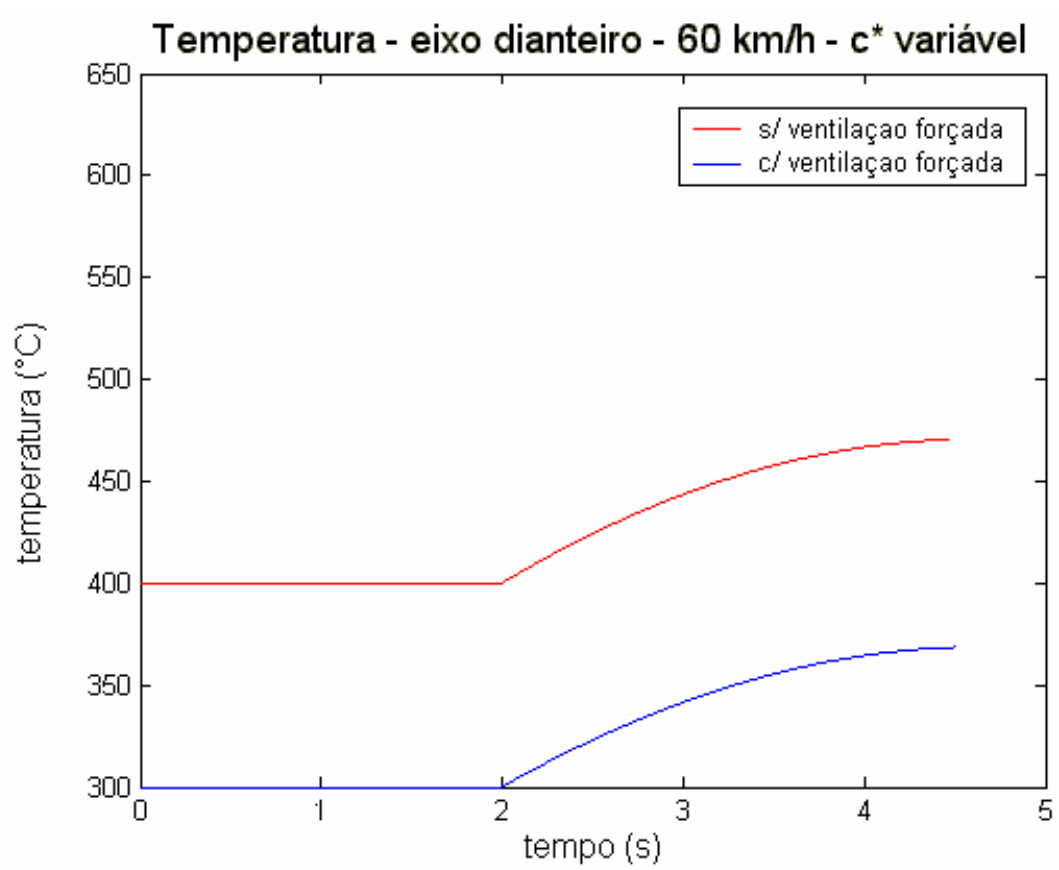

Figura 86 - Temperatura no disco de freio dianteiro, com fator de freio variável, considerando diferentes condições de ventilação e velocidade inicial de frenagem de $60 \mathrm{~km} / \mathrm{h}$.

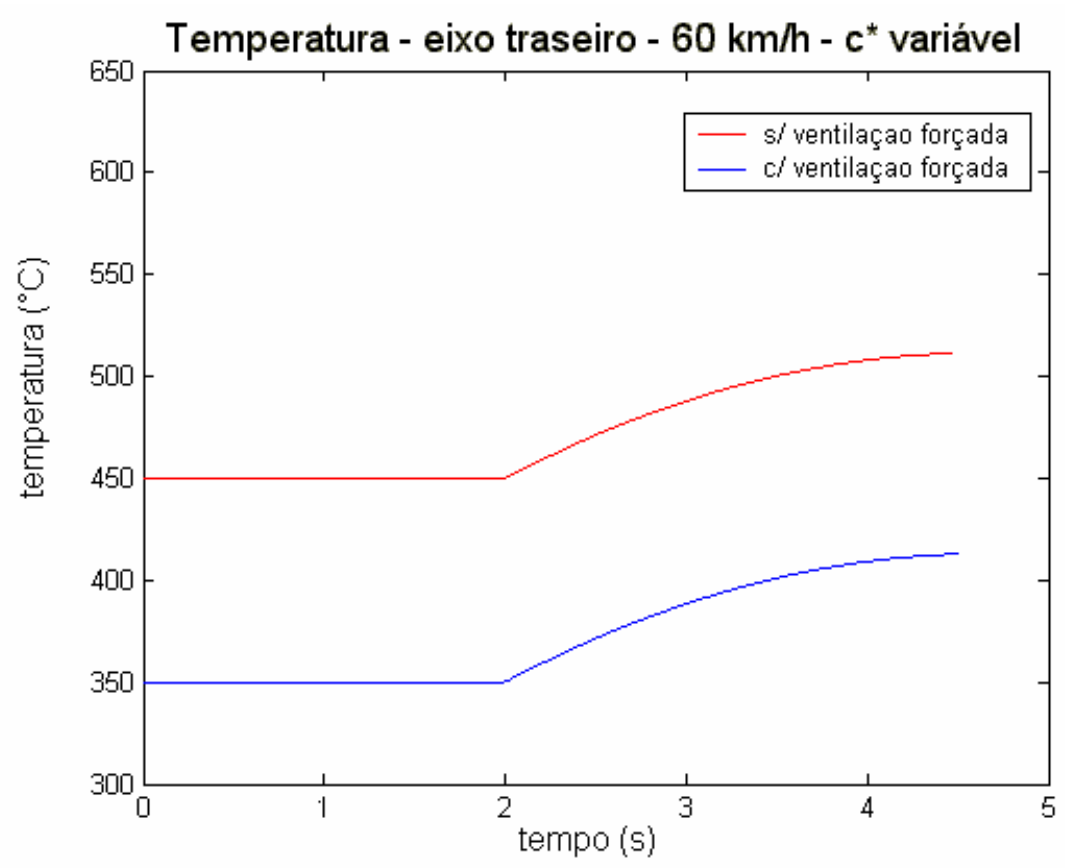

Figura 87 - Temperatura no disco de freio traseiro, com fator de freio variável, considerando diferentes condições de ventilação e velocidade inicial de frenagem de $60 \mathrm{~km} / \mathrm{h}$. 


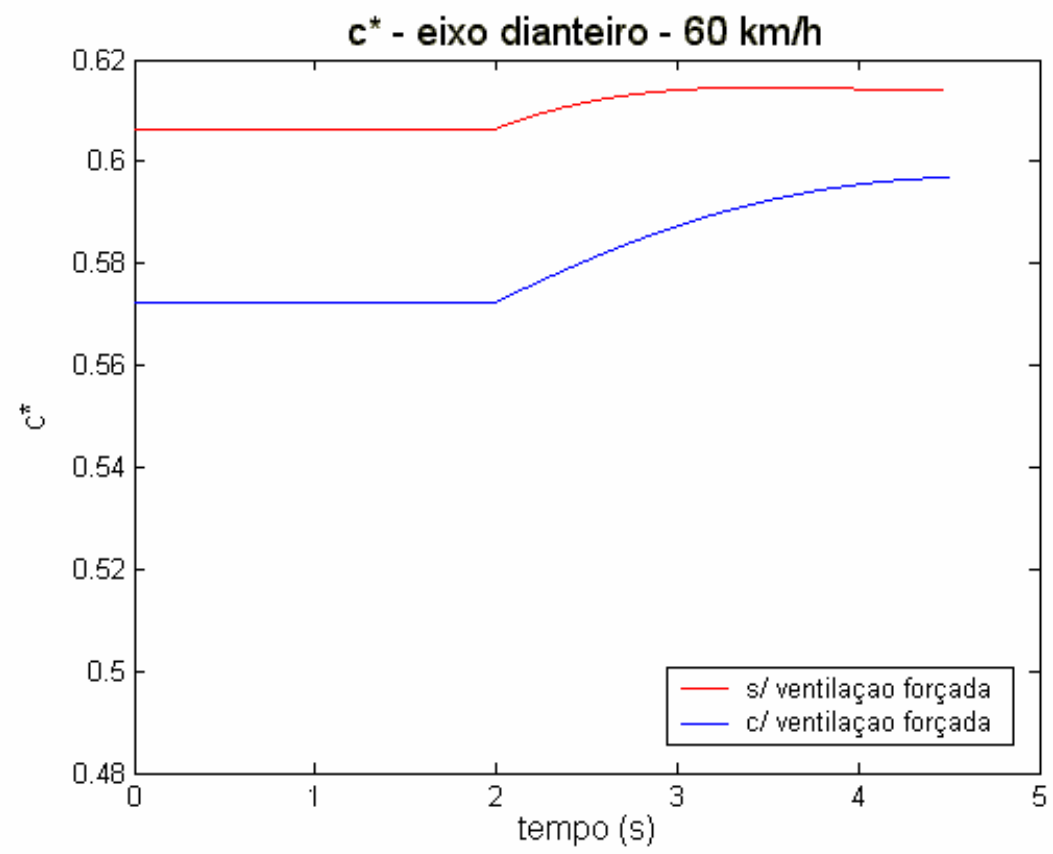

Figura 88 - Variação do fator de freio no eixo dianteiro, considerando diferentes condições de ventilação e velocidade inicial de frenagem de $60 \mathrm{~km} / \mathrm{h}$.

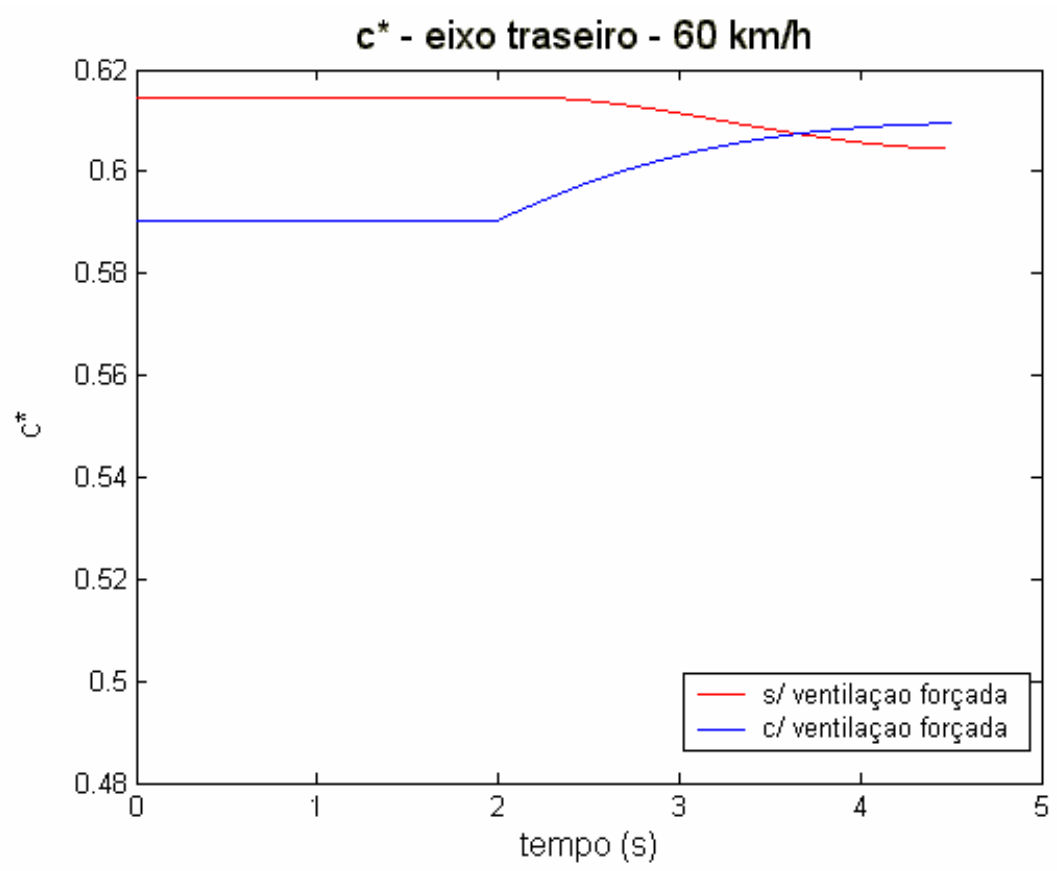

Figura 89 - Variação do fator de freio no eixo traseiro, considerando diferentes condições de ventilação e velocidade inicial de frenagem de $60 \mathrm{~km} / \mathrm{h}$. 
As Figuras 90 e 91 também mostram a recuperação do fator de freio sob ventilação forçada. Nota-se ainda que esta influência é mais significativa no eixo traseiro em virtude de sua condição normal de ventilação deficiente. Conseqüentemente, as forças de frenagem também serão maiores, como mostram as Figuras 92 e 93 e melhor utilizadas, aproximando o escorregamento parcial de seu limite como ilustra a Figura 94.

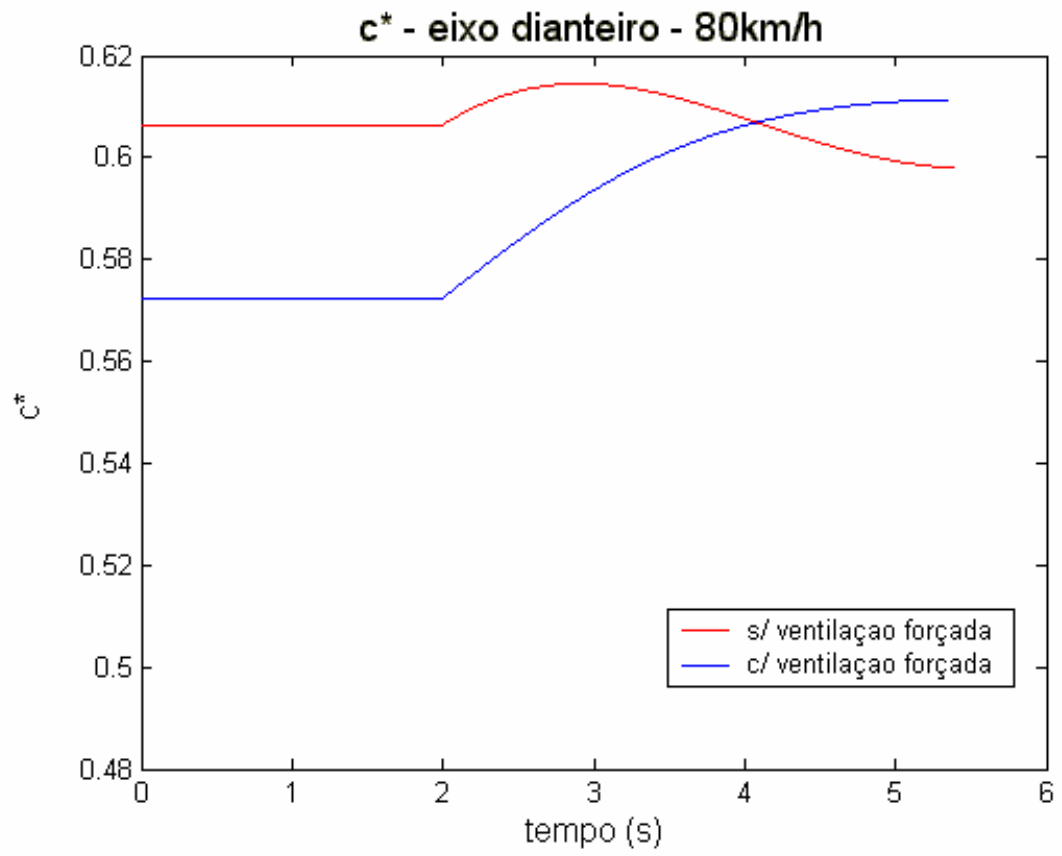

Figura 90 - Variação do fator de freio no eixo dianteiro, considerando diferentes condições de ventilação e velocidade inicial de frenagem de $80 \mathrm{~km} / \mathrm{h}$. 


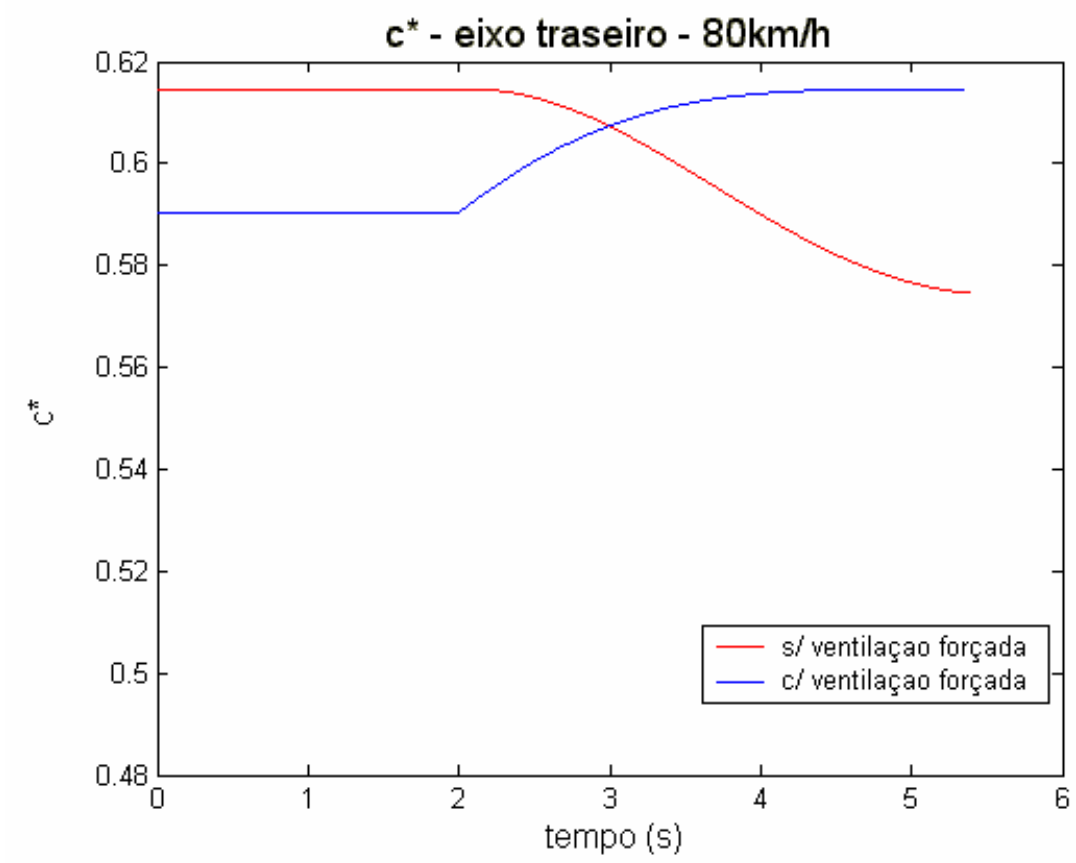

Figura 91 - Variação do fator de freio no eixo traseiro, considerando diferentes condições de ventilação e velocidade inicial de frenagem de $80 \mathrm{~km} / \mathrm{h}$.

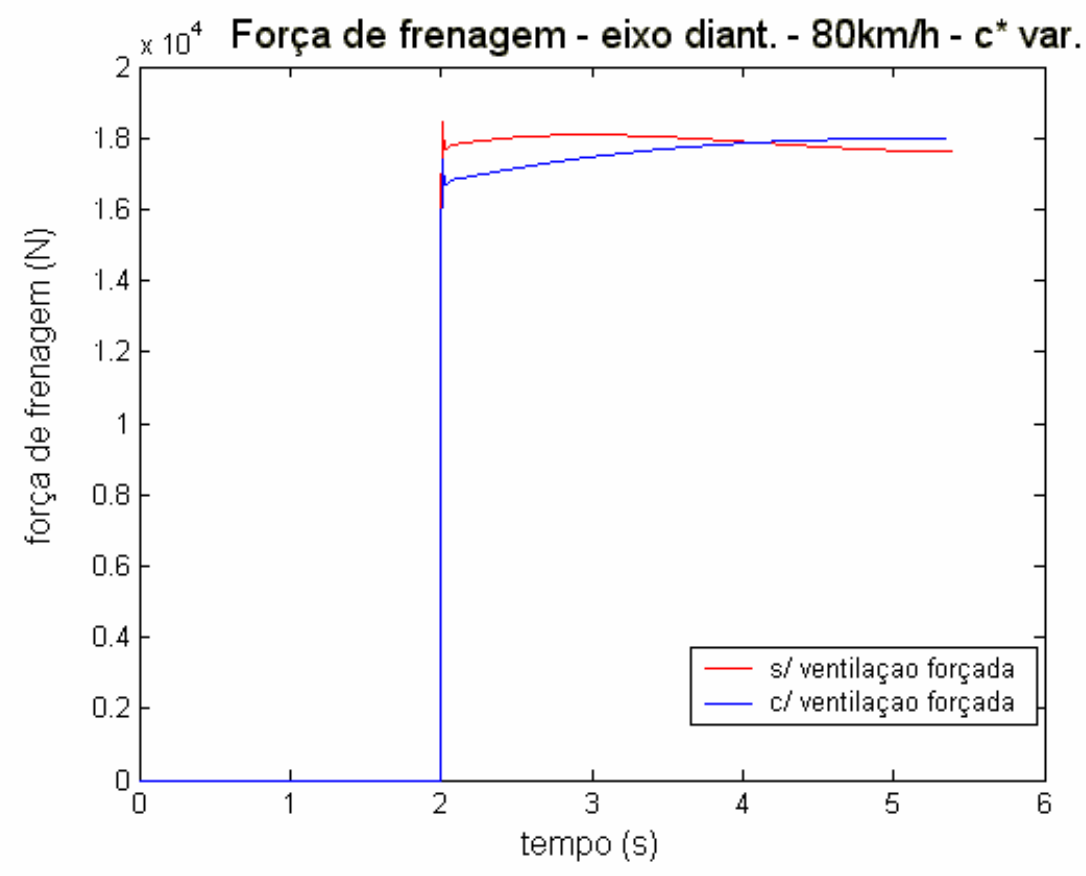

Figura 92 - Força de frenagem no eixo dianteiro, com fator de freio variável, considerando diferentes condições de ventilação e velocidade inicial de frenagem de $80 \mathrm{~km} / \mathrm{h}$. 


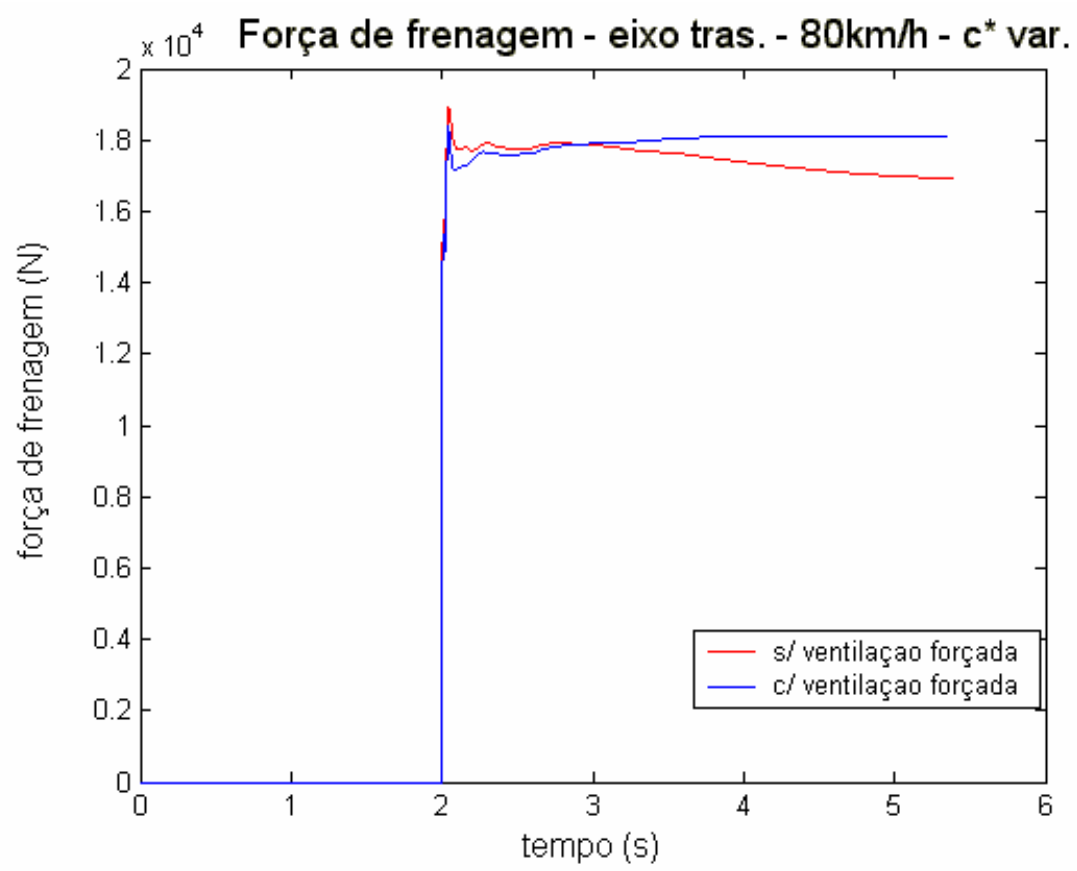

Figura 93 - Força de frenagem no eixo traseiro, com fator de freio variável, considerando diferentes condições de ventilação e velocidade inicial de frenagem de $80 \mathrm{~km} / \mathrm{h}$.

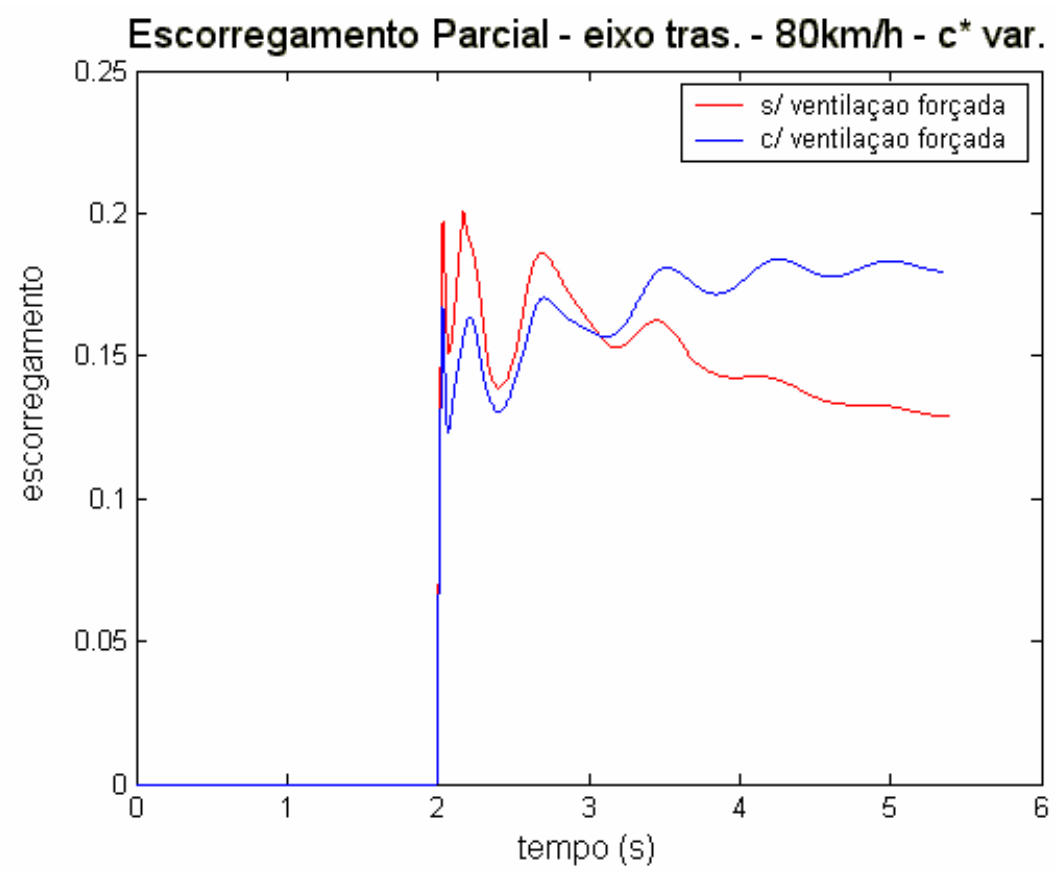

Figura 94 - Escorregamento parcial do eixo traseiro, com fator de freio variável, considerando diferentes condições de ventilação e velocidade inicial de frenagem de $80 \mathrm{~km} / \mathrm{h}$. 
As Figuras 95 e 96 mostram a variação nos níveis térmicos, considerando a presença de ventilação forçada. Em virtude da velocidade inicial de frenagem considerada, $100 \mathrm{~km} / \mathrm{h}$, as temperaturas atingidas são bastante elevadas e normalmente ocorreria uma grande queda no fator de freio, como mostram as Figuras 97 e 98. No entanto, a ventilação forçada pode inverter esta condição do fator de freio e conseqüentemente aumentar as forças de frenagem, ilustradas nas Figuras 99 e 100, melhorando também o aproveitamento destas forças, como se vê na Figura 101, e do balanceamento do veículo, ilustrado no coeficiente de aderência da Figura 102.

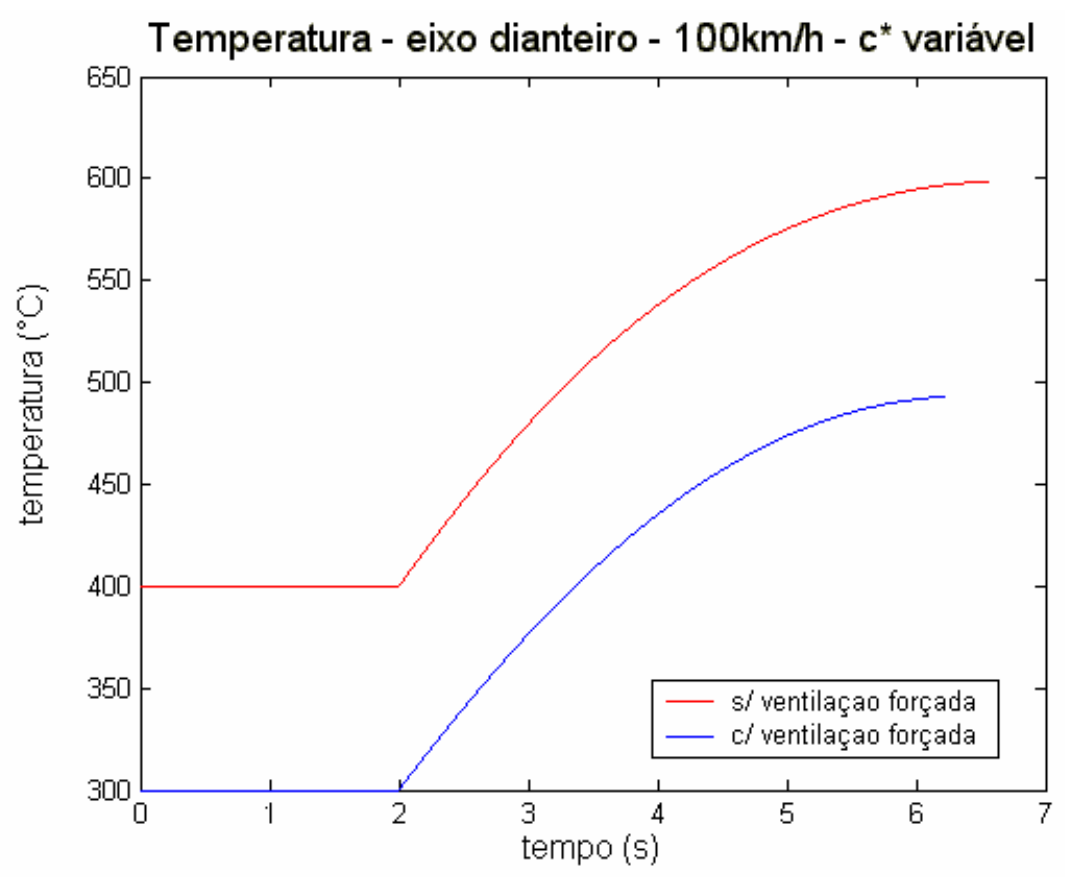

Figura 95 - Temperatura no disco de freio dianteiro, com fator de freio variável, considerando diferentes condições de ventilação e velocidade inicial de frenagem de $100 \mathrm{~km} / \mathrm{h}$. 


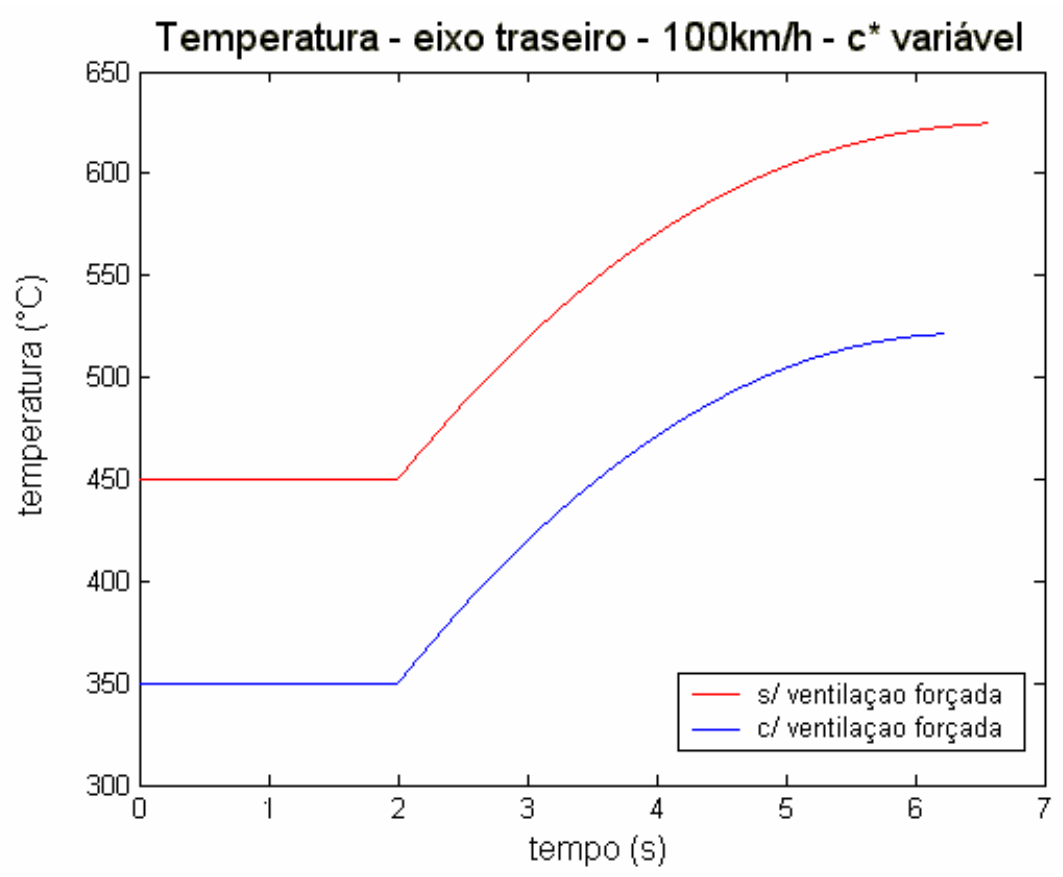

Figura 96 - Temperatura no disco de freio traseiro, com fator de freio variável, considerando diferentes condições de ventilação e velocidade inicial de frenagem de $100 \mathrm{~km} / \mathrm{h}$.

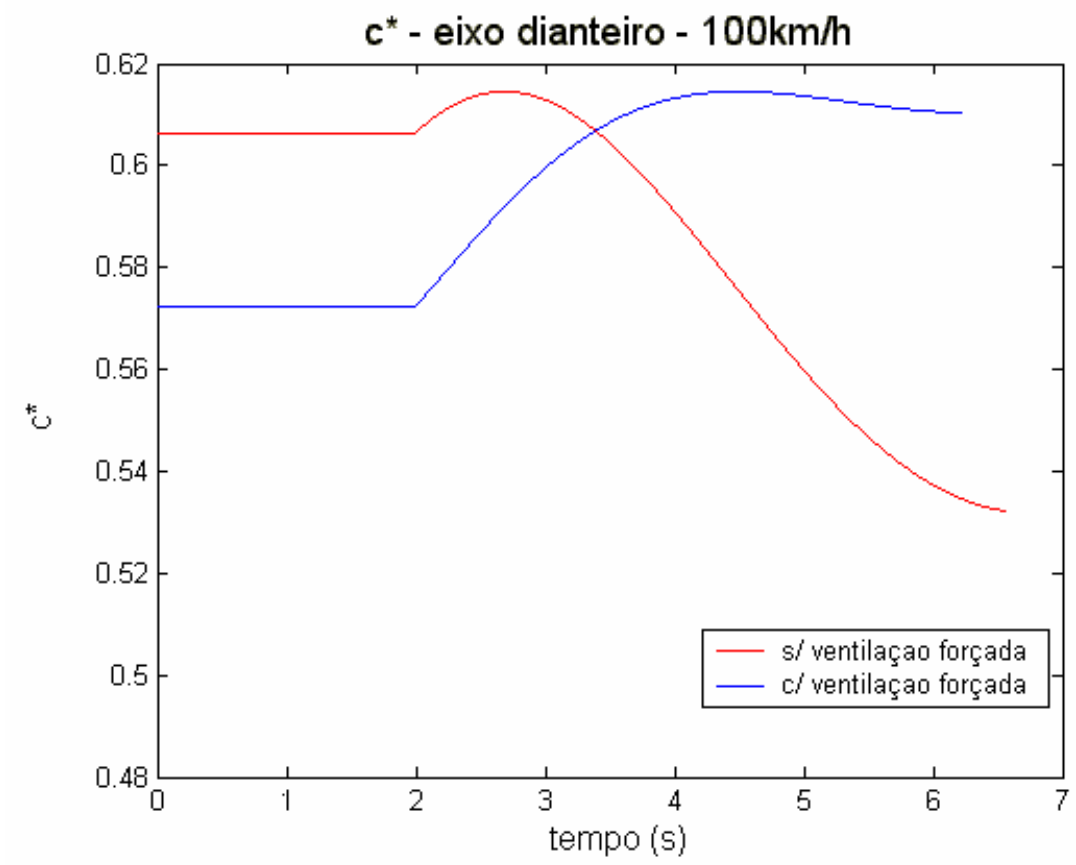

Figura 97 - Variação do fator de freio no eixo dianteiro, considerando diferentes condições de ventilação e velocidade inicial de frenagem de $100 \mathrm{~km} / \mathrm{h}$. 


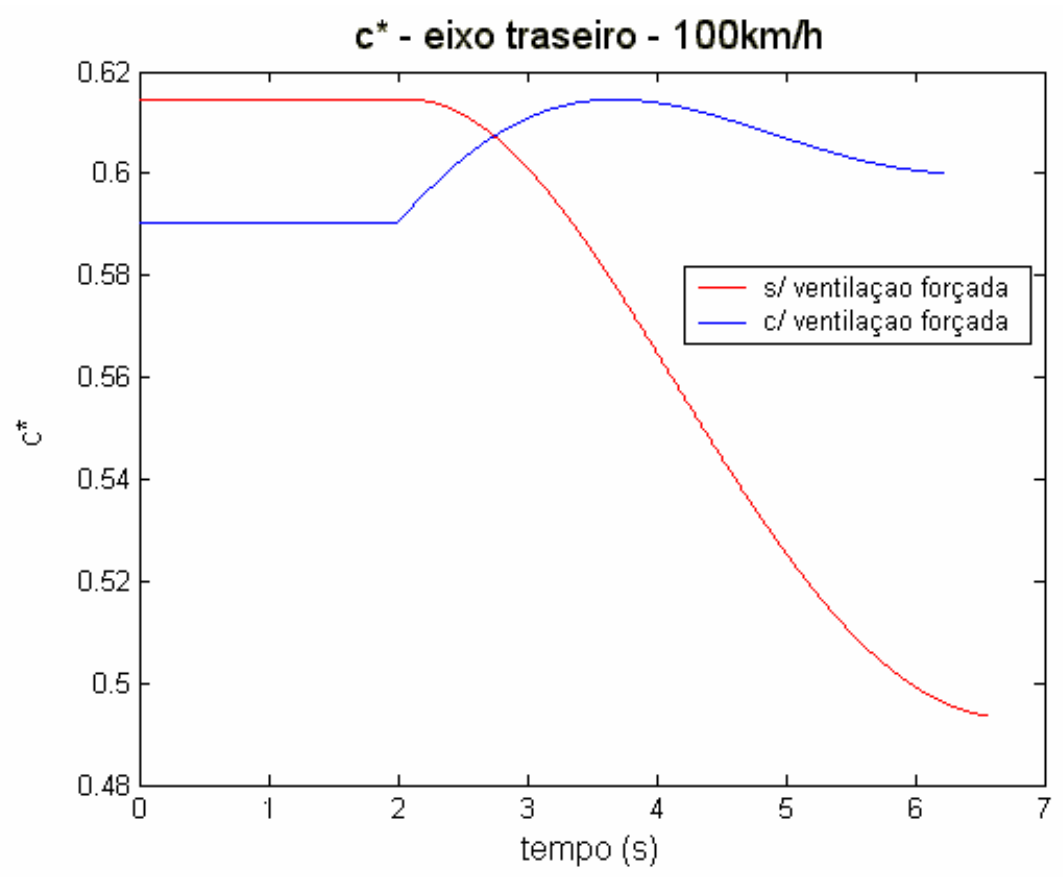

Figura 98 - Variação do fator de freio no eixo traseiro, considerando diferentes condições de ventilação e velocidade inicial de frenagem de $100 \mathrm{~km} / \mathrm{h}$.

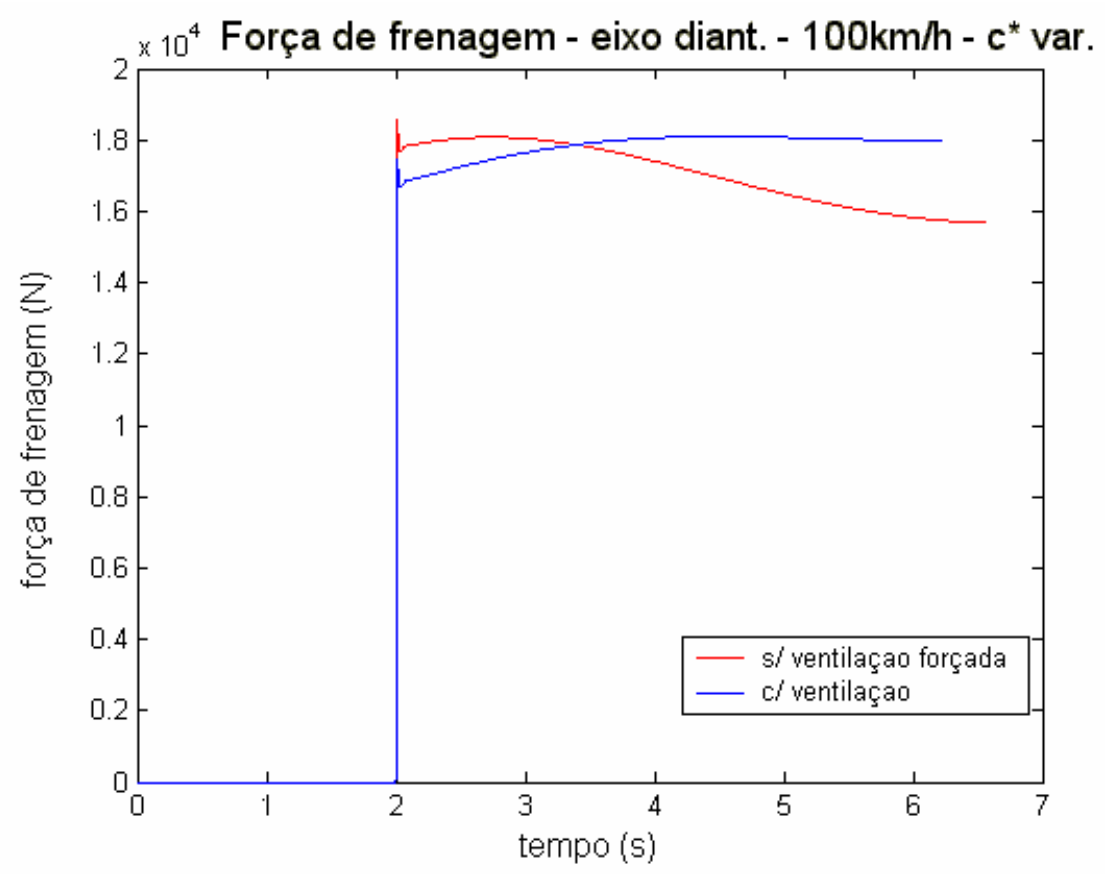

Figura 99 - Força de frenagem no eixo dianteiro, com fator de freio variável, considerando diferentes condições de ventilação e velocidade inicial de frenagem de $100 \mathrm{~km} / \mathrm{h}$. 


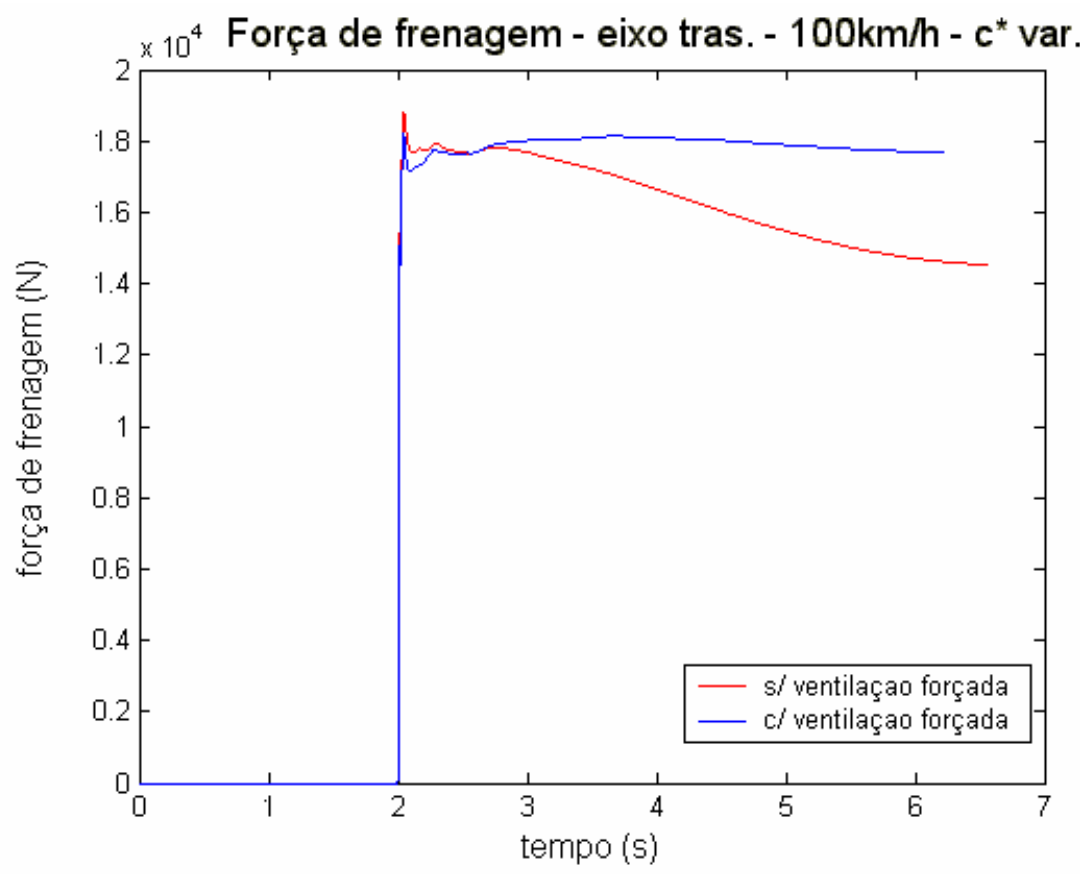

Figura 100 - Força de frenagem no eixo traseiro, com fator de freio variável, considerando diferentes condições de ventilação e velocidade inicial de frenagem de $100 \mathrm{~km} / \mathrm{h}$.

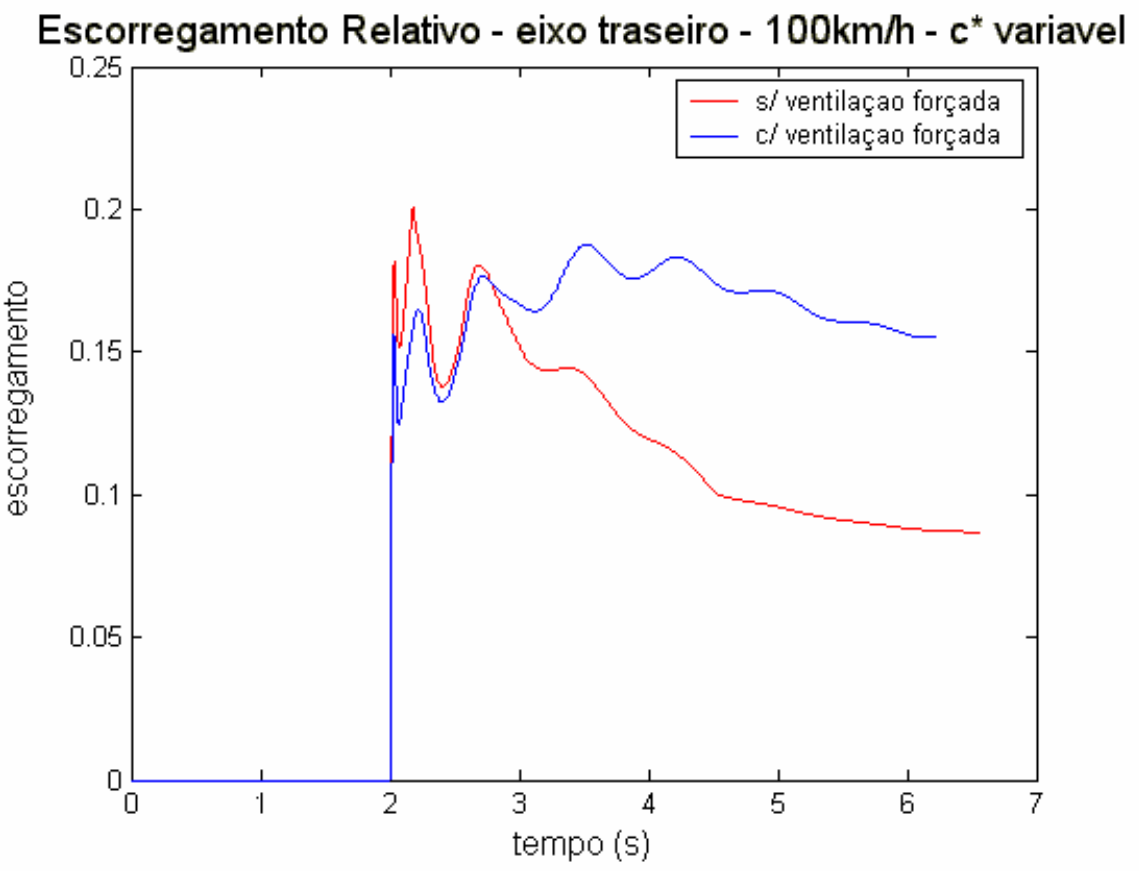

Figura 101 - Escorregamento relativo no eixo traseiro, com fator de freio variável, considerando diferentes condições de ventilação e velocidade inicial de frenagem de $100 \mathrm{~km} / \mathrm{h}$. 


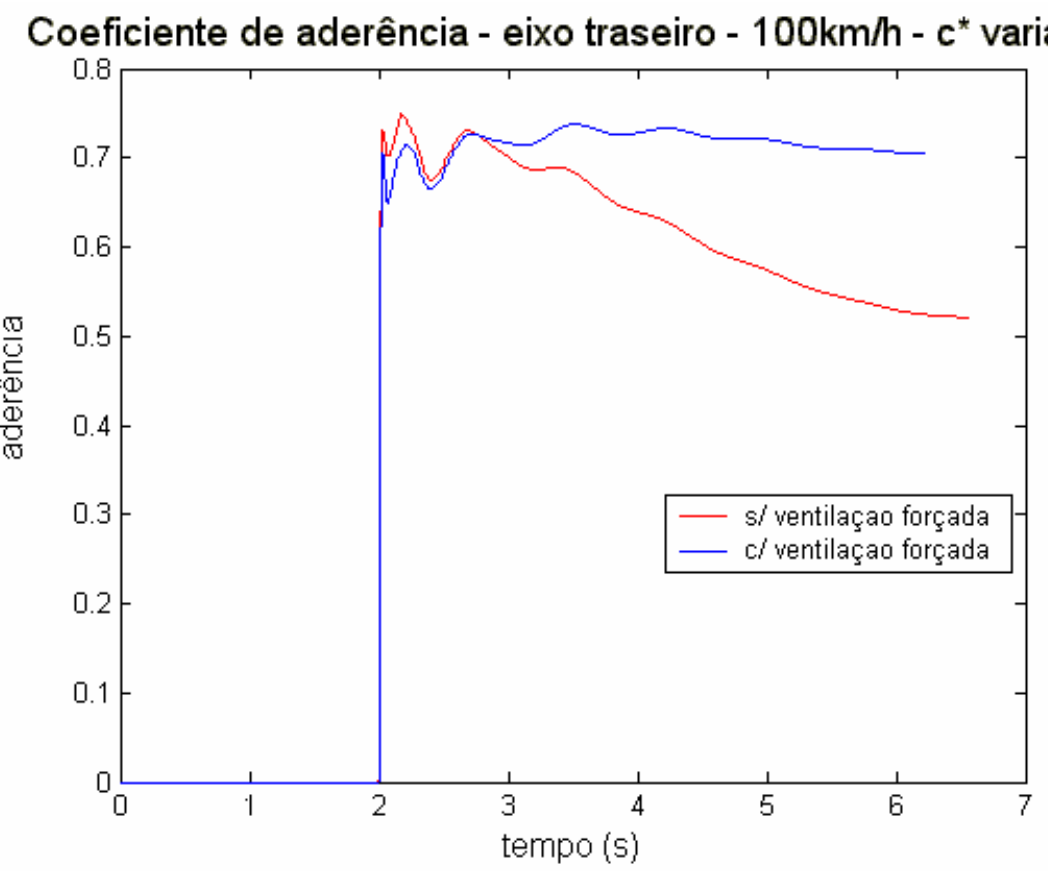

Figura 102 - Coeficiente de aderência do eixo traseiro, com fator de freio variável, considerando diferentes condições de ventilação e velocidade inicial de frenagem de $100 \mathrm{~km} / \mathrm{h}$.

A sexta simulação considera o veículo freando a partir de diferentes velocidades iniciais ( $60 \mathrm{~km} / \mathrm{h}, 80 \mathrm{~km} / \mathrm{h}$ e $100 \mathrm{~km} / \mathrm{h}$ ), a partir de uma temperatura de estabilização de $450^{\circ} \mathrm{C}$ no eixo traseiro e $400^{\circ} \mathrm{C}$ no eixo dianteiro, para um fator de freio variável. Foi ainda avaliada a mesma simulação, apenas modificando as temperaturas de estabilização $450^{\circ} \mathrm{C}$ no eixo dianteiro, alteração esta proporcional à instalação de um equipamento de proteção (espelho) no sistema de freio.

Para uma velocidade inicial de frenagem de $60 \mathrm{~km} / \mathrm{h}$, a Figura 103 mostra o aumento nas temperaturas atingidas considerando a instalação do espelho no eixo dianteiro. Já no eixo traseiro, como mostra a Figura 104, a presença do espelho não influencia os níveis térmicos atingidos. Conseqüentemente, apenas o eixo dianteiro terá seu fator de freio reduzido, como mostram as Figuras 105 e 106. 


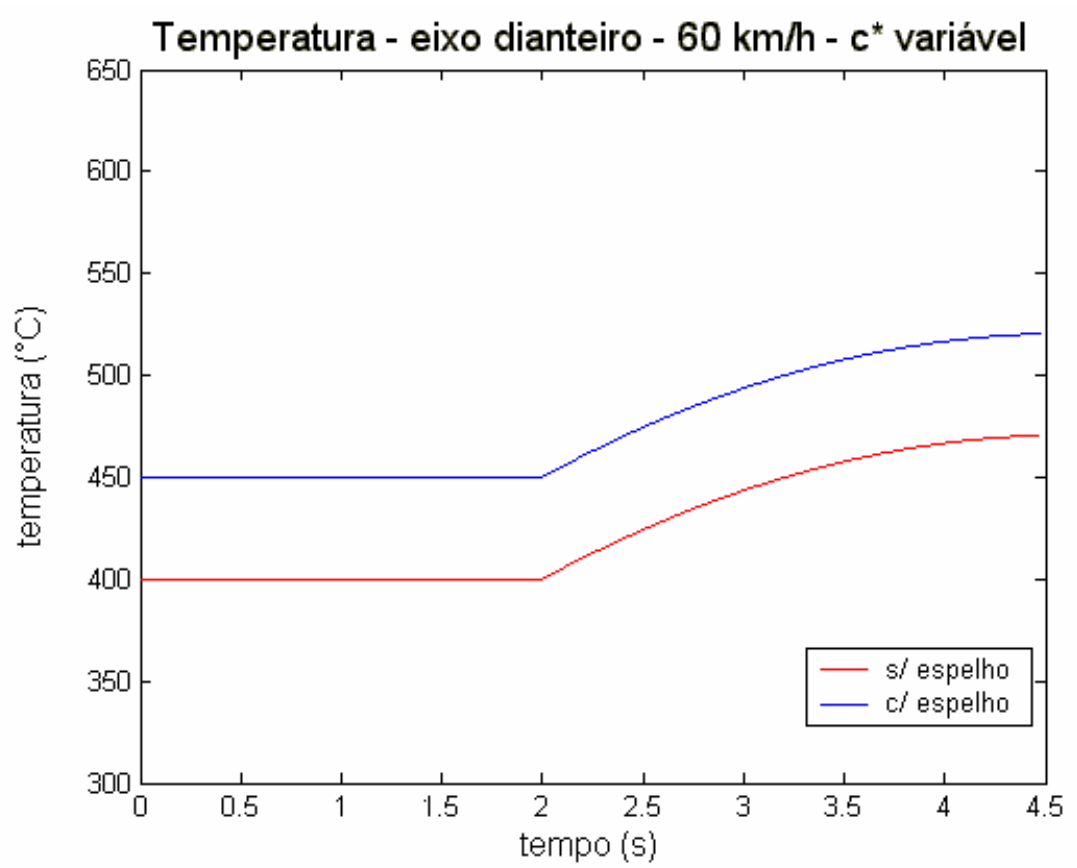

Figura 103 - Temperatura no disco de freio dianteiro, com fator de freio variável, considerando a instalação do espelho e velocidade inicial de frenagem de $60 \mathrm{~km} / \mathrm{h}$.

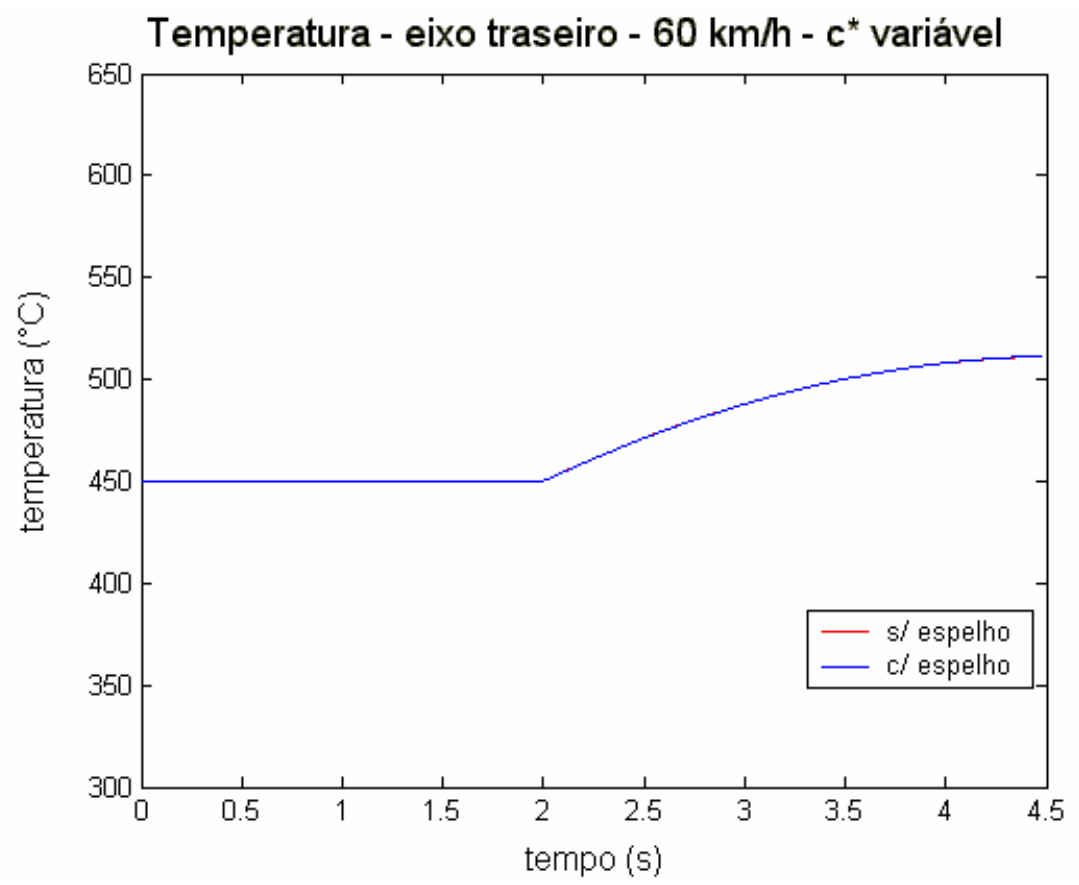

Figura 104 - Temperatura no disco de freio traseiro, com fator de freio variável, considerando a instalação do espelho e velocidade inicial de frenagem de $60 \mathrm{~km} / \mathrm{h}$. 


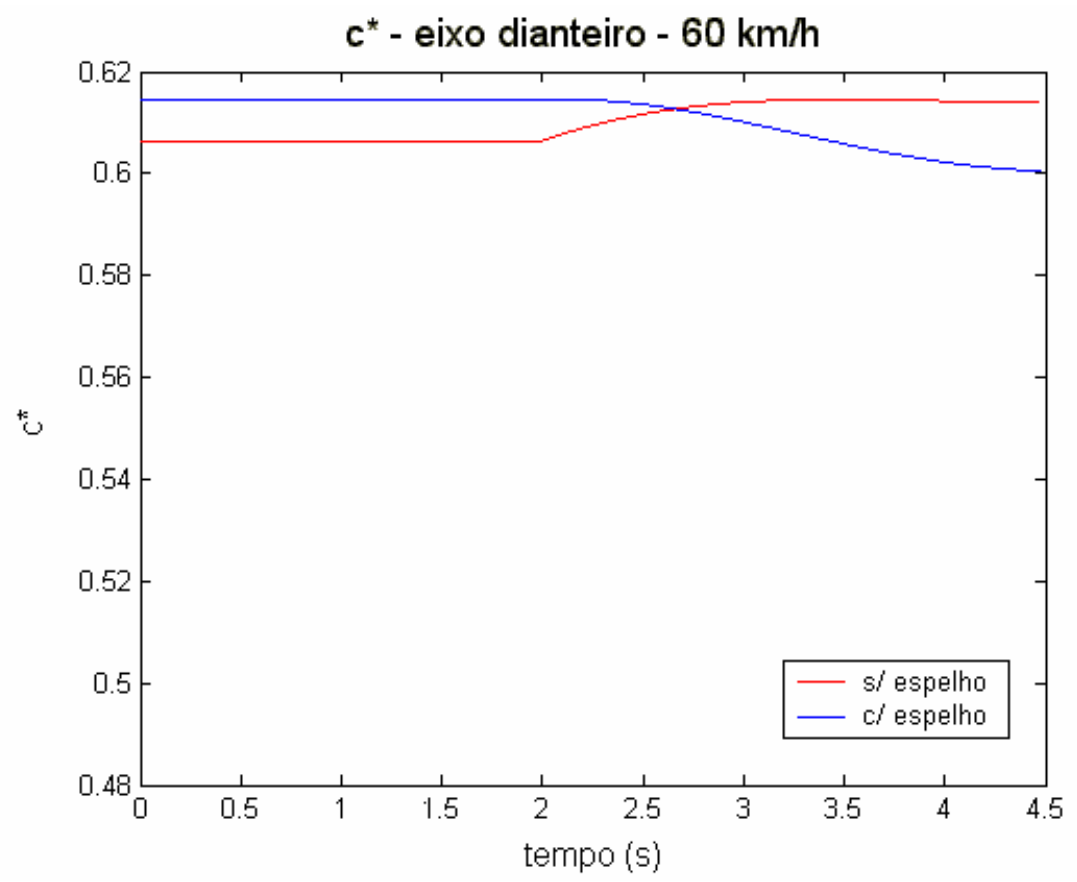

Figura 105 - Fator de freio no eixo dianteiro, considerando a instalação do espelho e velocidade inicial de frenagem de $60 \mathrm{~km} / \mathrm{h}$.

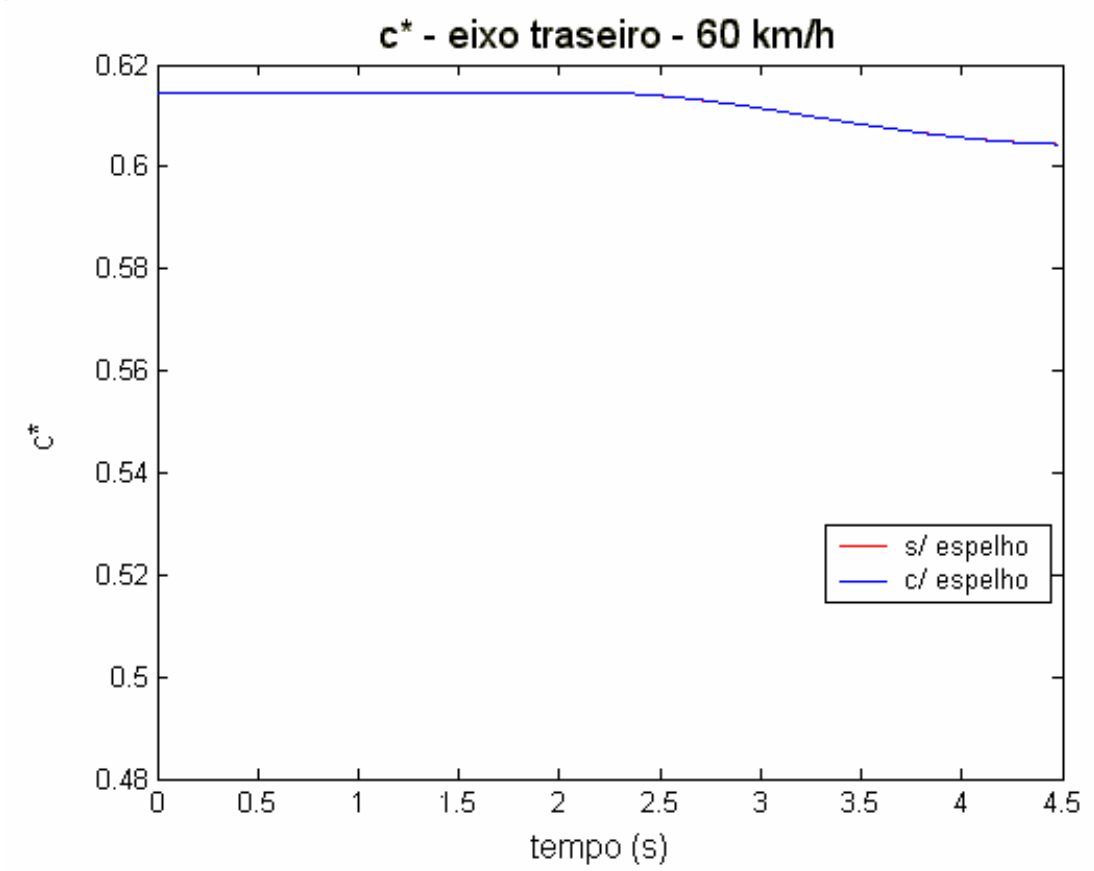

Figura 106 - Fator de freio no eixo traseiro, considerando a instalação do espelho e velocidade inicial de frenagem de $60 \mathrm{~km} / \mathrm{h}$. 
Na Figura 107 observa-se o aumento nos níveis térmicos com a presença do espelho, para uma velocidade inicial de frenagem de 80km/h. As Figuras 108 e 109 mostram a conseqüente queda no fator de freio e a redução das forças de frenagem, respectivamente.

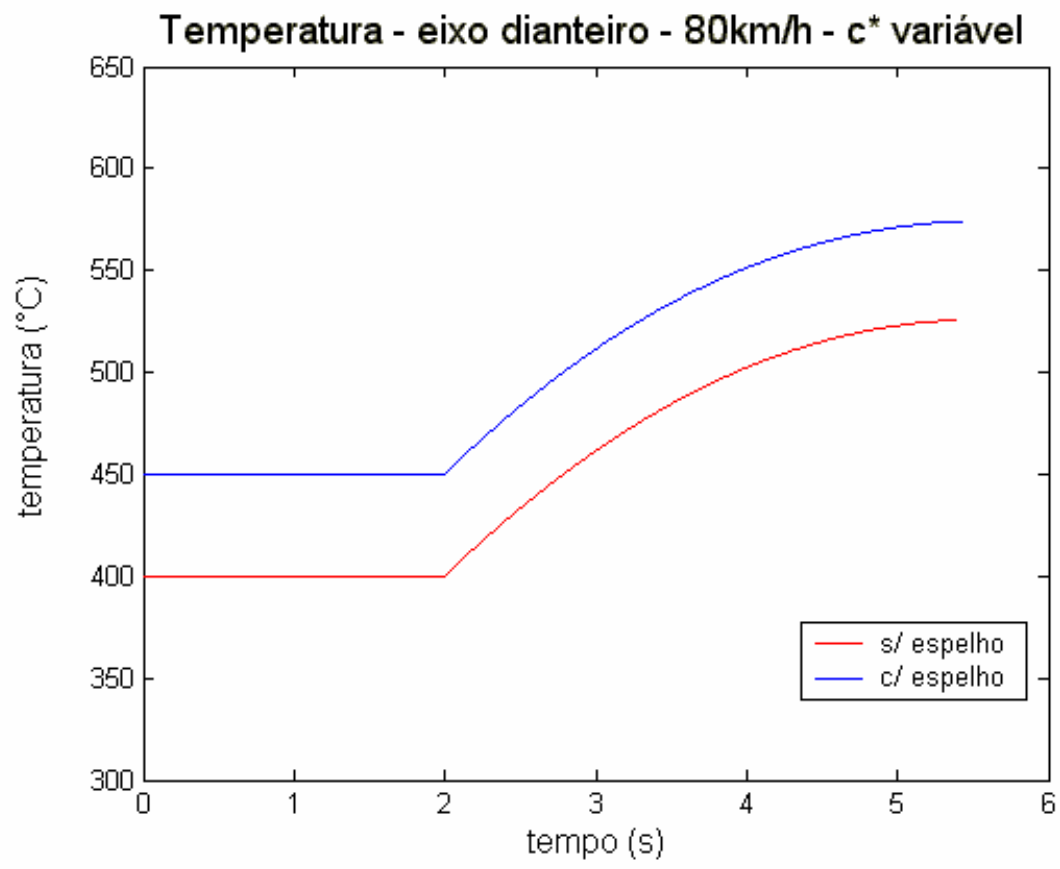

Figura 107 - Temperatura no disco de freio dianteiro, com fator de freio variável, considerando a instalação do espelho e velocidade inicial de frenagem de $80 \mathrm{~km} / \mathrm{h}$. 


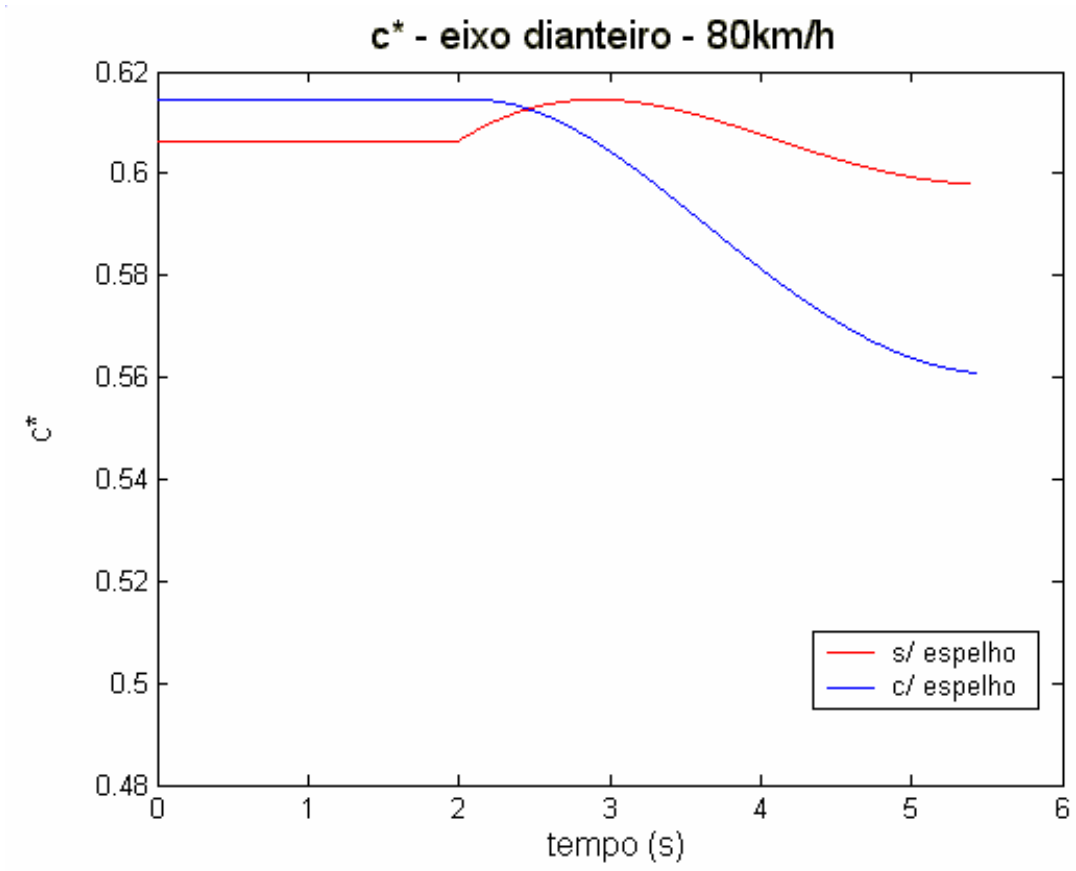

Figura 108 - Fator de freio no eixo dianteiro, considerando a instalação do espelho e velocidade inicial de frenagem de $80 \mathrm{~km} / \mathrm{h}$.

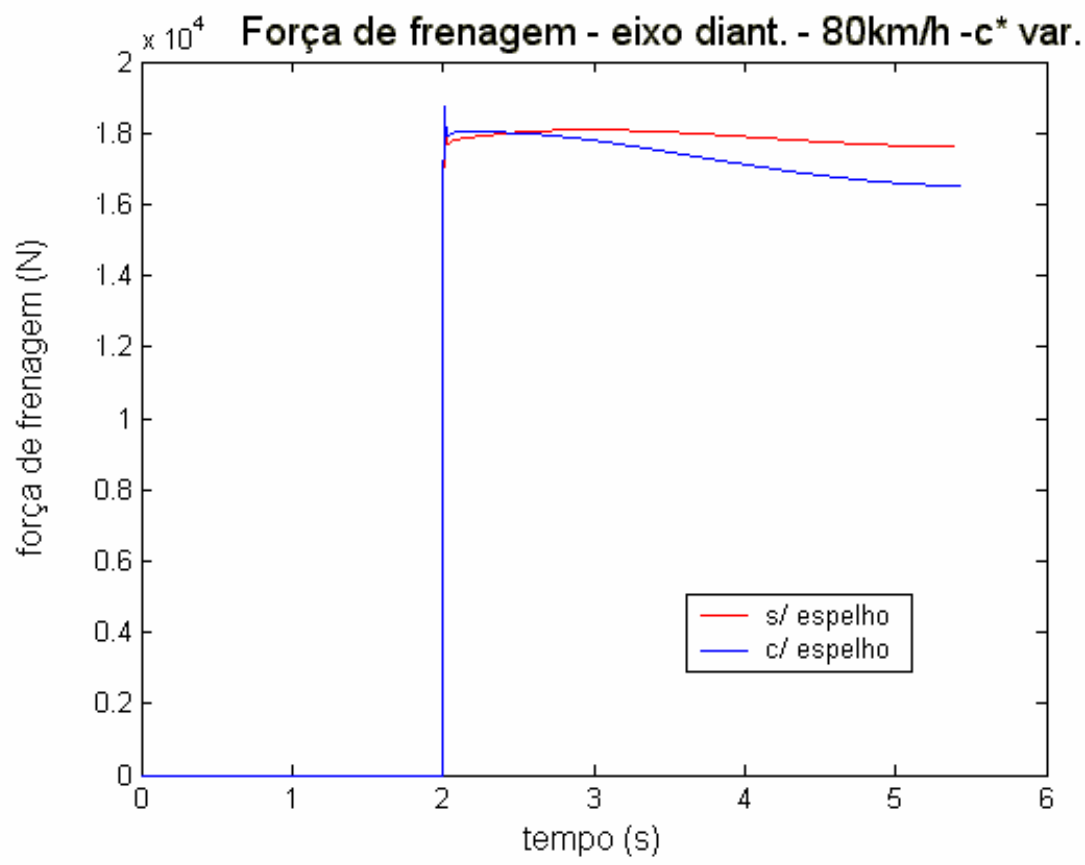

Figura 109 - Força de frenagem no eixo dianteiro, com fator de freio variável, considerando a instalação do espelho e velocidade inicial de frenagem de $80 \mathrm{~km} / \mathrm{h}$. 
Para uma velocidade inicial de frenagem de $100 \mathrm{~km} / \mathrm{h}$, os níveis térmicos atingidos, com a presença do espelho, são ainda maiores e a queda do fator de freio e da força de frenagem ainda mais acentuada, como mostram as Figuras 110, 111 e 112.

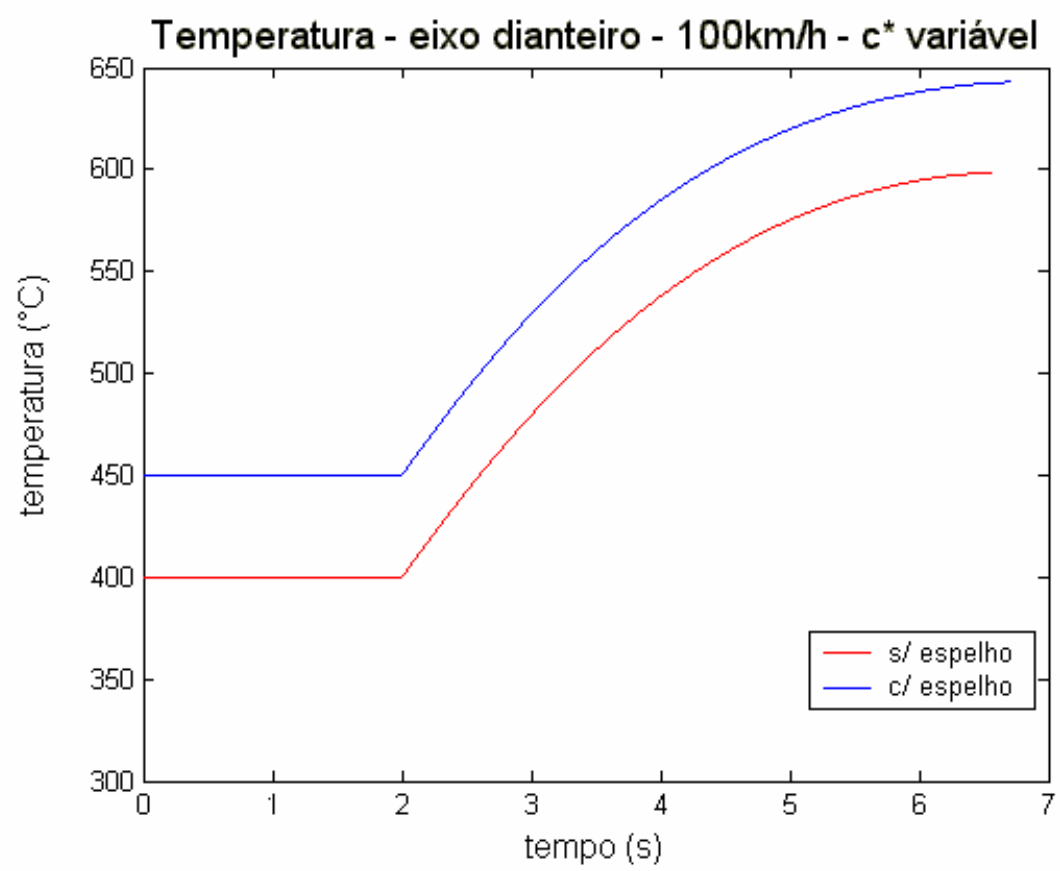

Figura 110 - Temperatura no disco de freio dianteiro, com fator de freio variável, considerando a instalação do espelho e velocidade inicial de frenagem de $100 \mathrm{~km} / \mathrm{h}$. 


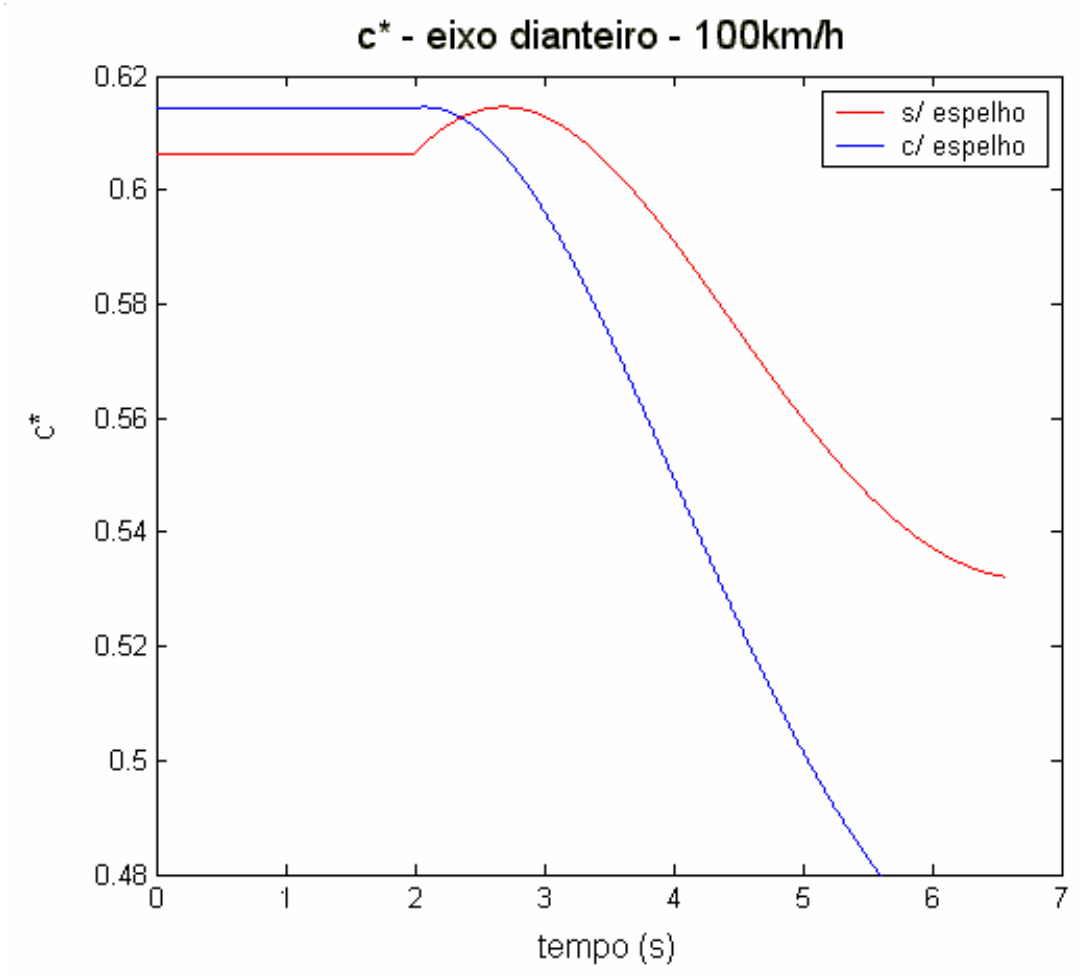

Figura 111 - Fator de freio no eixo dianteiro, considerando a instalação do espelho e velocidade inicial de frenagem de $100 \mathrm{~km} / \mathrm{h}$.

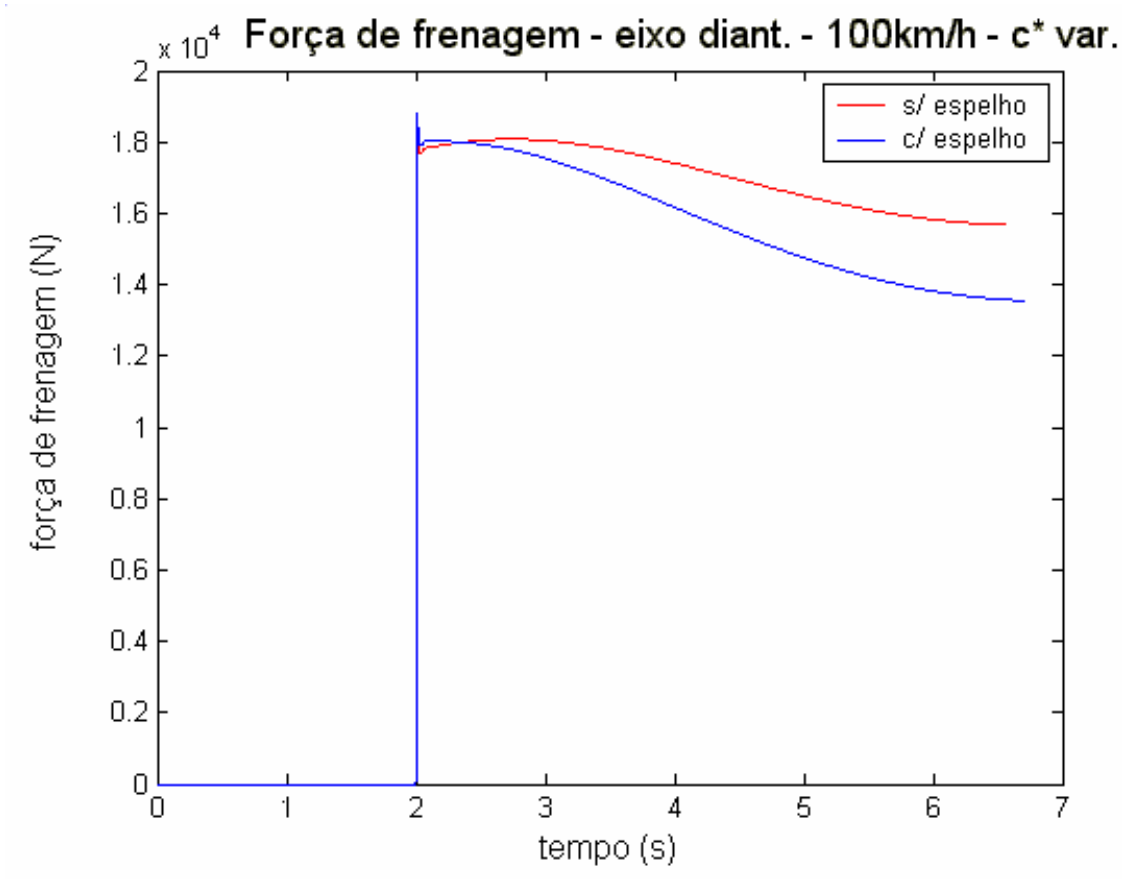

Figura 112 - Força de frenagem no eixo dianteiro, com fator de freio variável, considerando a instalação do espelho e velocidade inicial de frenagem de $100 \mathrm{~km} / \mathrm{h}$. 
Mais do que valores específicos, o resultado de tal avaliação térmica visa fornecer ao projetista uma ferramenta onde observe objetivamente perdas e ganhos nas modificações sugeridas ao sistema de freios de um veículo já projetado, ou no desenvolvimento de um veículo protótipo, com novas características do sistema de freios. 


\section{CONCLUSÕES}

Considerando-se a análise teórica desenvolvida neste trabalho, bem como os testes realizados tanto em perímetro urbano, como em pista de testes e em dinamômetro inercial, pode-se concluir que os objetivos deste trabalho foram alcançados. Um procedimento prático foi desenvolvido, com embasamento matemático e com utilização de recursos computacionais, de aplicação industrial, que permite prever o desempenho de um veículo em frenagens de emergência, sob condições operacionais severas, considerando os efeitos térmicos do sistema de freios.

Comparando-se os resultados obtidos nos testes de pista com os testes realizados em perímetro urbano, observa-se que o transitório, caracterizado pelo aumento contínuo da temperatura, não limitará o desempenho do veículo em frenagem de emergência.

Através dos testes de pista, utilizando-se um procedimento padrão de teste de fade (Teste Tipo 1), repetido seqüencialmente, foi possível atingir nos discos e pastilhas níveis de temperatura de estabilização similares aos obtidos nos testes em perímetro urbano. Tal conclusão permite a utilização dos testes de pista para desenvolvimento do par de fricção, evitando-se assim os riscos e complicações da exposição de um veículo protótipo ao tráfego urbano. Desta forma, também se torna possível a redução dos custos de desenvolvimento, diminuindo o tempo necessário para a realização dos testes.

Os testes realizados em dinamômetro mostraram a variação do fator de freio em relação à temperatura média do disco, bem como a variação de temperaturas na superfície do disco. Foi possível, desta forma, observar o comportamento do material de fricção, que possuindo uma curva de fator de freio sem bruscas variações, apresentou-se de boa qualidade. Também foi possível ainda observar-se os pontos 
mais críticos de aquecimento no disco através da câmera de infra-vermelho instalada junto ao dinamômetro, bem como verificar os picos de temperaturas atingidas.

Com a curva de fator de freio obtida em dinamômetro inercial, foi possível considerar no programa computacional desenvolvido, a variação do fator de freio em relação à temperatura. Esta avaliação do desempenho dinâmico do veículo, considerando seu comportamento térmico mostrou-se inovadora em relação à pesquisa bibliográfica realizada. Através das simulações computacionais realizadas, pode-se observar que a simplificação usualmente adotada de considerar o fator de freio constante durante a frenagem poderá implicar em erros significativos na avaliação do desempenho do veículo freando, como ilustram , entre outras, as Figuras 82, 83, 84 e 85.

No entanto, é importante observar-se no resultado das simulações que mesmo quando ocorre a redução do fator de freio sob determinadas condições de temperatura, o veículo ainda mostra-se capaz de realizar uma frenagem de emergência com eficiência, oferecendo forças de frenagens compatíveis e desacelerações superiores a $5 \mathrm{~m} / \mathrm{s}^{2}$, como ilustra a Figura 63 .

Apesar da legislação vigente exigir a realização de testes de fade em pista normalizada, bem como testes de durabilidade em perímetro urbano para efeitos de homologação, o programa computacional desenvolvido mostrou-se um processo simples de análise com recursos computacionais acessíveis e com um baixo custo envolvido, características estas muito importantes na fase de desenvolvimento e estudo de novos sistemas de freio ou de veículos protótipos.

Desta forma, torna-se possível reduzir sensivelmente os custos tanto de desenvolvimento dos novos sistemas de freios em veículos protótipos como de melhorias nos veículos já produzidos. As respostas da simulação computacional permitem ainda a redução dos custos de homologação, fornecendo uma previsão confiável do comportamento dinâmico do veículo na frenagem, o que possibilita a redução do número de testes para certificação. 


\section{PROPOSTAS DE TRABALHOS FUTUROS}

Durante o desenvolvimento deste trabalho foi considerado um veículo protótipo de dois eixos (4x2), especificamente um ônibus urbano. No entanto, grandes são ainda as oportunidades de análise e estudo, sendo possível aplicar a mesma metodologia de testes e cálculo a outros veículos leves ou pesados.

Mantendo o foco na segurança veicular de veículos pesados, uma proposta futura de trabalho é a avaliação térmica e dinâmica de veículos 6x2 e 6x4, desenvolvendo-se também modelos para quantificar as perdas de calor ocorridas durante a parte transitória do fenômeno térmico.

A partir do banco de dados levantado durante a fase de mapeamento térmico também será ainda possível avaliar-se o comportamento dos demais componentes monitorados durante a frenagem, como retentores, rolamentos, cubos de roda e pneus.

Através dos gráficos resultantes da simulação computacional pode-se avaliar a influência da suspensão, dos amortecedores, entre outros, no desempenho veicular durante a frenagem, o que torna este programa computacional uma ferramenta útil para avaliar o veículo em seu completo desempenho, não se limitando ao sistema de freios.

O programa de simulação computacional mostra ainda em aberto inúmeras possibilidades, como a introdução de válvulas, ou de outros componentes que modifiquem as características técnicas e construtivas do sistema de freios, bem como de outro sistemas do veículo, como suspensão, rodas e pneus, motor e diferentes carregamentos.

Outras propostas de trabalhos futuros podem ainda ser elaboradas considerando-se as modificações na legislação para a certificação de veículos pesados, utilizando-se como condições de contorno para o programa computacional 
os parâmetros definidos para homologação e analisando a influência das modificações no veículo sobre estes parâmetros. 


\section{REFERÊNCIAS BIBLIOGRÁFICAS}

ADAS, C. A.; FONSECA, B.J.;FERNANDES, D. L. G.; CANALE, A. C. (1995). A study of the influence of the brake force distribution on the directional stability of heavy vehicles during the brailing process. In: CONGRESSO E EXPOSIÇÃO INTERNACIONAIS DE TECNOLOGIA DA MOBILIDADE, 4., São Paulo, 1995. SAE Technical Paper Series: 952213.

BARBER, S. A.; TUTEN, J. M. (1986). Measurement of iterface temperatures during braking. In: TRUCK AND BUS MEETING AND EXPOSITION KING OF PRUSSIA, Pennsylvania, 1986. SAE Technical Paper Series 861985.

BENSEDDIQ, N.; WEICHERT, D.; SEIDERMANN, J.; MINET, M. (1996). Optimization of design of railway disc brake pads. Proceeding of the Institution of Mechanical Engineers. Part F. v.210, n.1, p.51-61.

BLANCO, C.; BERMEJO, J.; MARSH, H.; MENENDEZ, R. (1997). Chemical and physical properties of carbon as related to brake performance. Wear, v.213, n.1-2, dec., p.1-12.

BOIOCCHI, T. (1999). Technological differences between tractors, trailers and impact in the safety and drivability. In: COLOQUIUM INTERNACIONAL DE FREIOS, 4, Caxias do Sul, 1999, p.23-28.

BURKMAN, A. J. (1962). A laboratory method for testing moisture sensitivity of brake lining materials. In: NATIONAL AUTOMOBILE WEEK, Detroit, 1962. SAE Technical Paper Series 488A (620128). 
CANALE, A. C.; IOMBRILLER, S. F.; ADAS, C. A.; ANDRADE, F. A. P. (1999). Análise das variáveis do sistema de freios a disco no aspecto térmico. In: CONGRESSO E EXPOSIÇÃO INTERNACIONAIS DA TECNOLOGIA DA MOBILIDADE, 8, São Paulo, 1999. SAE Technical Paper Series 1999-01-3040P.

CANALE, A. C.; RUFINO, R. T. (1993). Estudo teórico do desempenho de um autoveículo rodoviário utilizando um sistema semi-automático. . In: CONGRESSO E EXPOSIÇÃO INTERNACIONAIS DA TECNOLOGIA DA MOBILIDADE, 2, São Paulo, 1993. SAE Technical Paper Series 931620.

CANALE, A. C.; RUFINO, R. T. (1993). Estudo de peso dinâmico no eixo e rodas do veículo usando o equilíbrio estático ou centro de gravidade do veículo. . In: CONGRESSO E EXPOSIÇÃO INTERNACIONAIS DA TECNOLOGIA DA MOBILIDADE, 2, São Paulo, 1993. SAE Technical Paper Series 931648.

CASSETTARI, A. (1998). Aerodinâmica de veículos terrestres: uma investigação teórica da resistência friccional. In: CONGRESSO E EXPOSIÇÃO INTERNACIONAIS DA TECNOLOGIA DA MOBILIDADE, 7, São Paulo, 1998. SAE Technical Paper Series 982865.

COSTA, A. L. A.; INGLESE, M. F.; NATAlinI, M.; XAVIER, O. A. M. (1996). Estudo do superaquecimento dos freios a tambor em ônibus urbanos e caminhões. In: CONGRESSO E EXPOSIÇÃO INTERNACIONAIS DE TECNOLOGIA DA MOBILIDADE, 5, São Paulo, 1996.

CUEVA, G.; TSCHIPTSCHIN, A. P.; SINATORA, A.; GUESSER, W. L. (2000). Desgaste de ferros fundidos usados em discos de freio de veículos automotores. In: CONGRESSO E EXPOSIÇÃO INTERNACIONAIS DE TECNOLOGIA DA MOBILIDADE, 9, São Paulo, 2000. SAE Technical Paper Series 2000-01-3252. 
DAY, A. J. (1988). An analysis of speed, temperature and performance characteristics of automotive drum brakes. Journal of tribology, v.110, p.209-305.

DAY, A. J.; NEWCOMB, T. P. (1980). The use of finite element analysis to predict radial temperature distributions in an annular brake path. In: LEEDS-LYON SYMPOSIUM ON TRIBOLOGY, 7th, 1980, p.333-340.

DAY, A. J.; NEWCOMB, T. P. (1984). The dissipation of frictional energy from the interface of an annular disc brake. Proceedings of the institution of mechanical engineers, part D. vol. 198, n. 11, p.201-209.

DAY, A. J.; HARDING, P. R. J.; NEWCOMB, T. P. (1984). Combined thermal and mechanical analysis of drum brakes. Proceedings of the institution of mechanical engineers, part D. vol. 198, n. 11, p.287-294.

DAY, A. J.; TIROVIC, M.; NEWCOMB, T. P. (1991). Thermal effects and pressure distributions in brakes. Proceedings of the institution of mechanical engineers, part D. vol. 205, n. 3, p.199-206.

DIKE, G. (1974). On optimum design of disc brake. Jornal of engineering for industry. vol. 96, n. 3, p.863-869.

DUSI, F. C.; ADAS, C. A.(2001). Segurança vehicular: tendencias mundiais para sistemas de freios em veículos comerciais. In: INTERNATIONAL BRAKE COLLOQUIUM, 5, Caxias do Sul, 2001. p. 67-70.

EBERT, D. G.; KAATZ, R. A. (1994). Objective characterization of vehicle brake feel.. SAE Technical Paper Series 940331.

EL ABDI, R.; SAMROUT, H. (1999). Anisothermal modeling applied to brake discs. International journal of non-linear mechanics. vol.34, n.5, p.795-805. 
FERNANDES, D. L. G. (2000). Análise de veículos rodoviários articulados pesados na freagem através da técnica dos mapas de desempenho. São Carlos. 214p. Tese de Doutorado - Escola de Engenharia de São Carlos - Universidade de São Paulo.

FERNANDES, D. L. G.; CANALE, A. C.; ADAS, C. A. (1998). Mapas de desempenho: uma análise completa do desempenho de veículos pesados na frenagem. In: CONGRESSO E EXPOSIÇÃO INTERNACIONAIS DA TECNOLOGIA DA MOBILIDADE, 7, São Paulo, 1998. SAE Technical Paper Series 982915.

FERNANDES, D. L. G.; ADAS, C. A.; HAGE, M. M.; CANALE, A. C. (2000). Análise da influência do carregamento no desempenho e estabilidade de veículos articulados pesados na freagem. In: CONGRESSO E EXPOSIÇÃO INTERNACIONAIS DA TECNOLOGIA DA MOBILIDADE, 9, São Paulo, 2000. SAE Technical Paper Series 2000-01-3284.

FUAD, K.; DAIMARUYA, M.; KOBAYASHI, H. (1994). Temperature and thermal stresses in a brake drum subjected to cyclic heating. Journal of thermal stresses, v.17, p.515-527.

FUKANO, A.; MATSUI, H. (1986). Development of disc brake design method using computer simulation of heat phenomena. In: INTERNATIONAL CONGRESS AND EXPOSITION, Detroit, 1986. SAE Technical Paper Series 860634.

GARRO, A.; GAVELLO, E.; ROSSI, F. (1981). Thermal transient analysis of disc brake problems concerning a mathematical model. SAE Technical Paper Series 811328.

GILLESPIE, T. D. (1992). Fundamentals of vehicle dynamics. 2 ed. Warrendale, SAE. 
GOHRING, E.; VON GLASNER, E. C. (1988). Performance comparison of drum and disc brakes for heavy-duty commercial vehicles. In: INTERNATIONAL CONFERENCE ON DISC BRAKES FOR COMMERCIAL VEHICLES, London, 1988. Paper C462/88, p.105-114.

GOHRING, E.; VON GLASNER, E. C. (1990). Performance comparison of drum and disc brakes for heavy-duty commercial vehicles. In: TRUCK AND BUS MEETING AND EXPOSITION, Detroit, 1990. SAE Technical Paper Series 902206.

GRIEVE, D. G.; BARTON, D. C.; CROLLA, D. A.; BUCKINGHAM, J. T. (1998). Design of a lightweight automotive brake disc using finite element and Taguchi techniques. Journal of automobile engineering, v.212, p.245-254.

GUDMAND-HOYER, L.; BACH, A.; NIELSEN, G. T.; MORGEN, P. (1999) Tribological properties of automotive disc brakes with solid lubrificants. Wear, v.232, n.2, October, p.168-175.

GUESSER, W. L.; GUEDES, L. C. (1997). Desenvolvimentos recentes em ferros fundidos aplicados à indústria automobilística. Simpósio de Engenharia Automotiva, 9., AEA, São Paulo, agosto.

HARDING, P. R. J.; WINTLE, B. J. (1978). Flexural effects in disc brake pads. Proceedings of the institution of mechanical engineers, vol.192, p. 1-7.

HARTTER, L. L.; SCHWARTZ, H. W.; RHEE, S. K. (1974). Evaluating copper alloy brake discs by thermal modeling. In: AUTOMOTIVE ENGINEERING CONGRESS, Detroit, 1974. SAE Technical Paper Series 740560.

HIGHLEY, F. H. (1971). Techniques for determining the thermal characteristics of brake drums and discs. SAE Technical Paper Series 710589. 
HOHMANN, C.; SCHIFFNER, K.; OERTER, K.; REESE, H. (1999). Contact analysis for drum brakes and disk brakes using ADINA. Computers and Structures. vol.72, July, p.185-198.

HOLMAN, J. P. (1983). Transferência de calor. Trad. Por Luiz Fernando Milanez. São Paulo, McGraw-Hill.

INGRAM, B. (1983). Aplication of disc brakes to commercial vehicles. In: BRAKING OF ROAD VEHICLES - IMECHE CONFERENCE. Paper C30/83, p.89-100.

IOMBRILLER, S. F. (1997). Estudo do desempenho na frenagem de emergência de um ônibus considerando o efeito da temperatura no contato lona/tambor. São Carlos, 1997. 81p. Dissertação (Mestrado) - Escola de Engenharia de São Carlos, Universidade de São Paulo.

JIMBO, Y.; MIBE, T.; AKIYAMA, K.; MATSUI, H.; YOSHIDA, M.; OZAWA, A. (1990). Development of high thermal conductivity cast iron for brake disk rotors. Society of automotive engineers transactions. vol.99, n.5, p.1-7. SAE Technical Paper Series 900002.

KENNEDY JR., F. E.; LING, F. F. (1974). A thermal, thermoelastic and wear simulation of a high-energy sliding contact problem. Journal of lubrication technology, v.96, p.497-507.

KERN, D. Q. (1982). Processos de transmissão de calor. Trad. por Adir M. Luiz, Rio de Janeiro, Guanabara Dois.

KLOOS, E. (1999). Theoretical and experimental investigation into disc cracks of air actuated disc brakes for trucks with a total weight of $>7,5$ t. In: COLOQUIUM INTERNACIONAL DE FREIOS, 4, Caxias do Sul, 1999, p.36-39. 
KOWALSKI, M. F.; EBERT, D. G. (1993). Brake design parameters for customer satisfaction. Automotive Engineering, v.101, n. 6, p. 13-16, jun.

KRÜSEMANN, R.; SCHMIDT, G. (1995). Analysis and optimization of disk brake cooling via computational fluid dynamics. In: INTERNATIONAL CONGRESS AND EXPOSITION, Michigan, 1995. SAE Technical Paper Series 950791.

KRÜSEMANN, R.; URBAN, J.; ZAJCEV, V. (1997). Brake disk temperature calculation in ABAQUS based on heat transfer coefficients from numerical flow simulation. In: ABAQUS USER'S CONFERENCE PROCEEDINGS, jun., Milão, 1997, p.445-460.

LAGEDROST, J. F.; ELDRIDGE, E. A.; STONE, D. H. (1979). Thermal property measurements in brake shoe materials. In: CONFERENCE ON RAILWAY BRAKING. Paper C160-79, p.111-114.

LIMPERT, R. (1975). Cooling analysis of disc rotors. In: TRUCK MEETING, Philadelphia, 1975. SAE Technical Paper 751014.

LIMPERT, R. (1992). Brakes: design and safety. Warrendale, SAE.

MARCON, F. (1999). Avaliação de discos de freio de diferentes fabricantes quanto ao desgaste e performance do freio. In: COLOQUIUM INTERNACIONAL DE FREIOS, 4, Caxias do Sul, 1999. p.130-135.

MINEGISHI, H.; SHIMIZU, H.; WAKAMATSU, H.; YOSHINO, Y. (1984). Prediction of brake pad wear / life by means of brake severity factor as measured on a data logging system. In: INTERNATIONAL CONGRESS \& EXPOSITION, Michigan, 1984. SAE Technical Paper Series 840358.

MOORE, M. W.; WATTON, B. (1971). Disc brake pad wear evalution. Proceedings of the institution of mechanical engineers, vol.185, 12/71. 
MORGAN, S.; DENNIS, R. W. (1972). A theoretical prediction of disc brake temperatures and a comparison with experimental data. In: AUTOMOTIVE ENGINEERING CONGRESS, Detroit, 1972. SAE Technical Paper Series 720090.

NAERHEIM, Y.; PAN, J.; MIN, P. (1999). A tribometer for studying friction films in brakes. In: COLOQUIUM INTERNACIONAL DE FREIOS, 4, Caxias do Sul, 1999, p.7-20.

NEWCOMB, T. P. (1960). Temperatures reached in disc brakes. Journal of mechanical engineering science, vol.2, n.3, p.167-177.

NEWCOMB, T. P.; MILLNER, N. (1965). Cooling rates of brake drum and discs. Proceedings of the institution of mechanical engineers, vol.180, n.6, p.191-205.

NEWCOMB, T. P.; SPURR, R. T. (1966). Braking of road vehicles. Chapman \& Hall, London.

NICHOLSON, G. (1995). Facts about friction. Ed. Gedoran.

OLIVEIRA, Z.A.A.; ANTONELLI, R.L.; VANZETTI, N.F.D. (1993). Nova técnica para aumentar a vida útil do material de atrito dos freios a ar tipo S'came e pneus aplicados em caminhões, ônibus e semi-reboques, sem aumentar custos. In: CONGRESSO E EXPOSIÇÃO INTERNACIONAIS DE TECNOLOGIA DA MOBILIDADE, 2, São Paulo, 1993. SAE Technical Paper Series 931621.

PAUL, D.; BUENO JR., R. A. (1999). Comparativo experimental em semi-reboques. In: COLOQUIUM INTERNACIONAL DE FREIOS, 4, Caxias do Sul, 1999, p.49-62. 
PAULETTI, R. M. (1993). Determinação do campo de temperaturas em rodas de ônibus urbanos. In: SIMEA - SIMPÓSIO DE ENGENHARIA AUTOMOTIVA, 7., São Paulo, 1993. Anais. São Paulo, p.220-229.

POVEL, R.; BERGMANN, H.; VON GLASNER, E. C.; MARWITZ, H. (2000). Active safety of commercial vehicles - the European status. In: CONGRESSO E EXPOSIÇÃO INTERNACIONAIS DE TECNOLOGIA DA MOBILIDADE, 9, São Paulo, 2000. SAE Technical Paper Series 2000-01-3154.

RAMACHANDRA RAO, V. T. V. S.; RAMASUBRAMANIAN, H. (1988). Computer modelling of temperature distribution in brake drums for fade assessment. Proceedings of the institution of mechanical engineers, vol. 202, p. 257-264.

RENFROE, D. A. (1990). Representation of brake operational characteristics using a one line equation. In: INTERNATIONAL CONGRESS AND EXPOSITION, Detroit, 1990. SAE Technical Paper Series 900167.

RHEE, S. K. (1974). Friction coefficient of automotive friction materials - its sensitivity to load, speed, and temperature. In: AUTOMOTIVE ENGINEERING CONGRESS, Detroit, 1974. SAE Technical Paper Series 740415.

RITZ, S., ADAS, C.A.; FRANCISCO, E.G. (1995). Definição de um modelo matemático para análise e cálculo do freio de roda tipo simplex sob o aspecto termodinâmico. In: CONGRESSO E EXPOSIÇÃO INTERNACIONAIS DE TECNOLOGIA DA MOBILIDADE, 4, São Paulo, 1995. SAE Technical Paper Series 952288.

ROMARO, M. (1998). Segurança veicular: a contribuição da correta divulgação de seus conceitos para a segurança no trânsito. In: CONGRESSO E EXPOSIÇÃO INTERNACIONAIS DE TECNOLOGIA DA MOBILIDADE, 7, São Paulo, 1998. SAE Technical Paper Series 982934. 
ROWSON, D. M. (1978). The interfacial surface temperature of a disc brake. Wear, vol.47, p.323-328.

SAMIE, F.; SHERIDAN, D. C. (1990). Contact analysis for a passenger car disc brake. Society of automotive engineers transactions, v.99, n.6, Sept, p.9-15.

SANTINI, J. J.; KENNEDY, F. E.; LING, F. F. (1976). Effect on design factors on surface temperature and wear in disk brakes. NASA contractor report 134923.

SARTORI, S. (1972). Uma contribuição ao estudo do aquecimento e ao ensaio dos freios de tambor. 227p. Campinas. Dissertação (Mestrado). - Faculdade de Engenharia Mecânica - Universidade de Campinas.

SCHWARTZ, H. W.; HARTTER, S. K.; RHEE, S. K.; BYERS, J. E. (1975). Evaluation of gray iron brake discs for trucks by thermal modeling. In: TRUCK MEETING, Philadelphia, 1975. SAE Technical Paper n. 751013.

SCHWARTZ, H. W.; RHEE, S. K. (1977). Brake dynamometer evalution of the Detroit traffic road test. SAE Technical Paper n. 770026.

SEGAL, L. (1999). Diagnostic method for vehicle brakes. NDT\&E International, v.32, n.7, p. 369-373, oct.

SHERIDAN, D. C.; KUTCHEY, J. A.; SAMIE, F. (1988). Approaches to the thermal modeling of disc brakes. In: INTERNATIONAL CONGRESS AND EXPOSITION, Detroit, 1988. SAE Technical Paper Series 880256.

SILVA, J. M. R.; DIEHL, C. A. (1996). Os efeitos da composição química e estrutural sobre as propriedades térmicas e mecânicas dos tambores de freios. /Apresentado ao II COLLOQUIUM DE FREIOS - SAE, Caxias do Sul, 1996. 
SMALES, H. (1995). Friction materials - black art or science? Proceedings of the institution of mechanical engineers, part D, Journal of automobile engineering, vol. 209, n.3, p.151-157.

SPERANZA NETO, M.; SILVA, F. R.; MARTINEZ, J. F. (1992). Metodología de projeto em dinâmica de veículos utilizando os procedimentos de modelagem, simulação e análise de dinâmica dos sistemas. In: CONGRESSO E EXPOSIÇÃO INTERNACIONAIS DE TECNOLOGIA DA MOBILIDADE, 1, São Paulo, 1992. SAE Technical Paper Series 921480.

TANAKA, S.; KUBOTA, K.; IWASAKI, T.; HATANAKA, H. (1990). The compatibility of air disc brakes and s-can brakes installed on combination vehicles. Society of automotive engineers transactions, vol.99, n.2, Sept, p.653660. SAE Technical Paper n. 902201.

TIN, V. J. (1998). Termografia aplicada ao desenvolvimento térmico de veículos. In: CONGRESSO E EXPOSIÇÃO INTERNACIONAIS DE TECNOLOGIA DA MOBILIDADE, 7, São Paulo, 1998. SAE Technical Paper Series 982892.

TIROVIC, M.; TODOROVIC, J. (1988). Flexural effects in commercial vehicles'disc brake pads. In: CONFERENCE ON DISC BRAKES FOR COMMERCIAL VEHICLES, London, 1988, paper C455/88, p.47-52.

TRICHÊS JR., M.; JORDAN, R.; GERGES, S. N. Y.; TOUSSI, S. (2001). Análise modal de pastilhas de freio considerando os efeitos do amortecimento e da temperatura. In: International Brake Colloquium, 5, Caxias do Sul, 2001. p. 52-58.

VON GLASNER, E. C.; POVEL, R.; WUEST, K. (1994). Results and economical aspects of simulation systems evaluating the braking and steering performance of commercial vehicles. Heavy vehicle dynamics and simulation in braking, steering and suspension systems. SP-1059. SAE Technical Paper Series 942300. 
YEVTUSHENKO, A.; IVANYK, E. (1995). Determination of heat and thermal distortion in braking systems. Wear, vol.185, jun., p.159-165. 


\section{BIBLIOGRAFIA CONSULTADA}

ANDRADE, S. M.; JORGE, M. H. P. M. (2000). Características das vítimas por acidentes de transporte terrestre em município da Região Sul do Brasil. Rev. Saúde Pública, n.34, p.149-156.

AOKI, K. (1978). Trend of japanese truck, bus, and trailer brakes. In: TRUCK MEETING, Dearborn, 1978. SAE Technical Paper Series 781068.

ASHWORTH, F. J.; SHERBINY, M.; NEWCOMB, T. P. (1977). Temperature distribution and thermal distortion of brake drums. Proceedings of the institution of mechanical engineers, v.191, p.169-176.

BAKKER, E.; PACEJKA, H. B.; LIDNER, L. (1989). A new tire model with an application in vehicle dynamics studies. SAE Technical Paper Series 890087.

BARRETTI, R. S. D.; FRAGOSO, H. R.; SIMÕES, M. E. (1992). Nova sistemática para desenvolvimento de caminhões. In: CONGRESSO E EXPOSIÇÃO INTERNACIONAIS DE TECNOLOGIA DA MOBILIDADE, 1, São Paulo, 1992. SAE Technical Paper Series 921470.

BLAKEMORE, T. (1996). Safety in numbers. Transport engineer, p. 25-27, dec.

BOLINA, A. O. (1992). Potência em dois estágios: uma solução para a relação custodesempenho dos equipamentos. In: CONGRESSO E EXPOSIÇÃO INTERNACIONAIS DE TECNOLOGIA DA MOBILIDADE, 1, São Paulo, 1992. SAE Technical Paper Series 921482. 
BROGE, J. L. (2000). Heavy-duty truck safety systems. Automotive engineering international online, tech briefs, p. 4, may.

CARVALHO, F. (2000). Evolução nos transportes. Revista autodata, n.2020, p. 5455.

CARVALHO, F. (2000). Veículo seguro existe. Revista autodata, n.2020, p. 34-36.

CANALE, A. C. (1989). Automobilística: dinâmica e desempenho. São Paulo, Érica.

CANALE, A. C.; RUFINO, R. T. (1992). Estudo do desempenho na frenagem de autoveículos rodoviários utilizando a técnica do "balanceamento estático” ou “passeio do centro de gravidade”. In: CONGRESSO E EXPOSIÇÃO INTERNACIONAIS DE TECNOLOGIA DA MOBILIDADE, 1, São Paulo, 1992. SAE Technical Paper Series 921438.

CHICUREL, R. (1998). A compromise solution for energy recovery in vehicle braking. Energy, v.24, jan, p.1029-1034.

COBREQ - Informações técnicas sobre lonas e pastilhas para freios.

COLE, D. J.; CEBON, D. (1994) Predicting vertical dynamic tire forces of heavy trucks. In: VEHICLE, TIRE, PAVEMENT INTERFACE. Philadelphia. American Society for Testing and Materials, ASTM STP 1225, p.27-35.

DAIMARUYA, M.; KOBAYASHI, H.; FUAD, K. (1997). Thermoelasto-plastic stresses and thermal distortions in a brake drum. Journal of thermal stresses, v.20, n.3-4, p.345-361.

DUBENSKY, R. G. (1985). Experimental techniques for rotor performance measurements. SAE Technical Paper Series 850078. 
DUFRENOY, P.; WEICHERT, D. (1995). Prediction of railway disc brake temperatures taking the bearing surface variations into account. Proceedings of the Institution of Mechanical Engineers, Part F. Journal of Rail and Rapid Transit. V.209, n.2, p.67-76.

DUNAEVSKY, V. V. (1991). Prediction of railroad friction braking temperatures: prediction of average bulk and average surface temperatures of railroad wheels and brake discs. Tribology transactions, v.34, n.3, p.343-352.

FABCHER, P. S. (1981). Retarders for heavy Vehicles: evaluation of performance characteristics and in-service costs. Highway Safety Research Institute Phase I Technical Report to NHTSA, Contract No.DOT-HS-9-02239, University of Michigan, Feb., 1981.

FANCHER JR., P. S.; MATHEW, A. (1989). Performance factors for heavy trucks. Automotive engineering, v. 97, n. 11, p. 21-24, nov.

FERNANDES, D. L. G. (1994). Estudo da frenagem de autoveículos rodoviários articulados pesados. São Carlos. 153p. Dissertação (Mestrado) - Escola de Engenharia de São Carlos, Universidade de São Paulo.

FERNANDES, D. L. G.; CANALE, A. C.; ADAS, C. A. (1997). Performance, distribuition of heavy vehicles during braking process including ECE-13 requirements. In: CONGRESSO E EXPOSIÇÃO INTERNACIONAIS DE TECNOLOGIA DA MOBILIDADE, 6, São Paulo, 1997. SAE Technical Paper Series 973045.

FERMÉR, M.; LUNDÉN, R. (1991). Transient brake temperatures found by use of analytical solutions for finite hollow cylinders. Proceedings of institution of mechanical engineers. PartC: Mechanical engineering science, v.205, n.3, p.189200. 
FLAIM, T. A. (1989). Vehicle brake balance using objective brake factors. In: INTERNATIONAL CONGRESS AND EXPOSITION, Michigan, 1989. SAE Technical Paper Series 890804.

FUGANTI, A.; LORENZI, L. (1996). Performance of a redesigned MMC automotive brake drum. SAE Technical Paper Series 960994.

GAMA, R. M. S. (1984). Análise da troca de calor por radiação entre um arranjo simétrico formado por " $\mathrm{n}$ ” superfícies e o meio ambiente. Revista brasileira de ciências mecânicas, v. 6, n. 1, p. 59-74.

GAMA, R. M. S. (1985). Uma formulação variacional geral para problemas de troca de calor por radiação difusa. Revista brasileira de ciências mecânicas, n. 2, p. 163-169.

GELLING, I. R. (1994). Influence of tread polymer on traction, rolling resistance, and wear properties of tires. In: VEHICLE, TIRE, PAVEMENT INTERFACE. Philadelphia, B. T. Kulakowski. American Society for Testing and Materials, ASTM STP 1225, p.107-118.

GÖRING, E.; VON GLASNER, E. C.; POVEL, R. (1992). Aprimoramento das características de dirigibilidade e frenagem de veículos comerciais através da inteligência eletrônica. In: CONGRESSO E EXPOSIÇÃO INTERNACIONAIS DE TECNOLOGIA DA MOBILIDADE, 1, São Paulo, 1992. SAE Technical Paper Series 921440.

GOUYA, M.; NISHIWAKI, M. (1990). Study on disc brake groan. Society of automotive engineers transactions, v.99, n.6, Sept, p.16-22.

HAGE, M. M.; FERNANDES, D. L. G.; ADAS, C. A.; KOELSCH, W. E.; ROMANI, S. R.; SCABBIA, A.; SETTI, J. R. A. (2000). Dimensionamento e 
análise de uma rampa de escape para caminhões. In: CONGRESSO E EXPOSIÇÃO INTERNACIONAIS DE TECNOLOGIA DA MOBILIDADE, 9, São Paulo, 2000. SAE Technical Paper Series 2000-01-3232.

HARDY, M. S. A.; CEBON, D. (1995). Investigation of anti-locking strategies for heavy goods vehicles. Proceedings of institution of mechanical engineers. Part D: Journal of automobile engineering, v. 209, n. 4, p. 263-271.

HARRIES, D. A. (1978). Pedal feel with power braking systems. Lucas engineering review, v.7, n.3, p.65-69.

HARRISON, P. T. C.; LEVY, L. S.; PATRICK, G.; PIGOTT, G. H.; SMITH, L. L. (1999). Comparative hazards of chrysolite asbestos and its substitutes: a European perspective. Environmental health perspectives, v. 107, p.607-611.

HEGMON, R. R. (1992). Some results from ongoing research on road roughness. Vehicle, tire, pavement interface, ASTM STP 1164. J. J. Henry and J. C. Wambold, Eds., American Society for Testing and Materials, Philadelphia, 1992, p. 14-31.

HENDERSON, G. W.; SCHILKE, N. A. (1992). Mobility technology tomorrow II. Automotive engineering, v.100, n.5, p.23-30, may.

HERRERO, R. J.; SIGNORELLI, C. C.(1992). Plataforma de caminhões autolatina programa de racionalização. In: CONGRESSO E EXPOSIÇÃO INTERNACIONAIS DE TECNOLOGIA DA MOBILIDADE, 1, São Paulo, 1992. SAE Technical Paper Series 921475.

HIRANO, M. (1993). Development of vehicle - following distance warning system for trucks and buses. Proceedings of IEEE on vehicle navigation and information systems 93CH3285-4, p.513-516. 
IACOVIDES, H.; CHEW, J. W. (1993). The computation of convective heat transfer in rotating cavities. International journal of heat and fluid flow, v.14, n.2, jun., p.146-154.

IOMBRILLER, S. F.; CANALE, A. C. (2001). Anlysis of emergency braking performance with particular consideration of temperature effects on brakes. Journal of the brazilian society mechanical sciences, v.23, n.1.

IOMBRILLER, S. F.; CANALE, A. C.; ADAS, C. A.; ANDRADE, F. A. P. (2001). Modelagem do sistema de freios a disco considerando o aspecto térmico. In: INTERNATIONAL BRAKE COLLOQUIUM, 5., p.59-63.

JACOBSON, M. (1997). Eletronic braking systems review. Automotive engineer, v.22, n.1, p.54-55, feb.

JOHANSSON, G.; RUMAR, K.(1971). Driver's brake reaction times. Human factors, v. 13, n.1, p.23-27.

JOHNSON, L. K.; FANCHER, P. S.; GILLESPIE, T. D. (1978). An empirical model for the prediction of the torque output of commercial vehicle air brakes. Highway Safety Research Institute, University of Michigan, Technical Report No.UMHSRI-78-53,1978.

JORGE, M. H. P. M. (1997). Acidentes e violências no Brasil I - análise dos dados de mortalidade. Revista Saúde Pública, v. 31, n.4, p. 5-25.

KAINRADL, P.; KAUFMANN, G. Heat generation in pneumatic tires. Rubber chemistry an technology, v.49, p.823-861.

KARCZEWSKI, J. (1992). Evolution in braking. Automotive engineering, v. 100, n.8, p. 10-11, aug. 
KEMPF, D.; BONDERSON, L.; SLAFER, L. (1987). Real time simulation for application to ABS development. SAE Technical Paper Series 870336.

KENNEDY, R. H.; MCMINN, M. S. (2000). Tire temperature prediction during post-cure inflation. Tire science and technology, v. 28, n.4, p. 248-263.

KENNET, P. (1996). Safe and sound in the long run. Transport engineer, p. 10-12, dec.

KETTELL, J. (1989). Friction materials for wet applications for the 1990's. In: 40TH ANNUAL EARTHMOVING INDUSTRY CONFERENCE, Illinois, April, 1989. SAE Technical Paper Series 890951.

KRAMER, D.; ROPER, D.; TRACKMAN, E. (1987). Drive axle antilock improves truck braking stability. Automotive Engineering, v.95, n.11, p.61-65, nov.

KRENKEL, W.; HENKE, T. (1999). Design of high performance CMC brake discs. High temperature ceramic matrix composites III, v.164, n.1, p.421-424.

KULAKOWSKI, B. T.; CHI, M. C.; LIN, C. M. (1992). Measurement and modeling of truck tire traction characteristics. In: VEHICLE, TIRE, PAVEMENT INTERFACE. Philadelphia, J. J. Henry and J. C. Wambold. American Society for Testing and Materials, ASTM STP 1225, p.112-124.

KUNG, S. W.; BRENT DUNLAP, K.; BALLINGER, R. S. (2000). Complex eingenvalue analysis for reducing low frequency brake squeal. In: CONGRESSO E EXPOSIÇÃO INTERNACIONAIS DE TECNOLOGIA DA MOBILIDADE, 9, São Paulo, 2000. SAE Technical Paper Series 2000-01-0444.

LERNER, N. (1993). Brake perception-reaction times of older and younger drivers. Human factors and ergonomics society, p.206-210. 
LIN, L.; COHEN, H. H. (1997). Accidents in the trucking industry. International journal of industrial ergonomics, v.20, p.287-300.

LISTER, R. D. (1950). The reaction times of drivers in moving and stationary vehicles. Road research laboratory, Crowthone, Berks, RN/1324/.

LIEBERMAN, D. G.; BEM-DAVID, G.; SCHWEIZER, N.; APTER, Y.; PARUSH, A. (1995). A field study on braking response during driving. Ergonomics, v. 38, p.1894-1910.

LIMBERG, C. A.; SIQUEIRA, L. P. (1999). Desenvolvimento do sistema de freio a fim de atender às curvas de aderência em caminhões e ônibus. In: INTERNATIONAL BRAKE COLLOQUIUM, 4.

LLANERAS, R. E.; SWEZEY, R. W.; BROCK, J. F.; ROGERS, W. C.; VAN COTT, H. P. (1998). Enhancing the safe driving performance of older commercial vehicle drivers. International journal of industrial ergonomics, v.22, Sept, p.217245.

LLOYD, F. A.; ANDERSON, J. N.; BOWLES, L. S. (1988). Effects of operating conditions on performance of wet friction materials: a guide to material selection. In: INTERNATIONAL OFF-HIGHWAY \& POWERPLANT CONGRESS AND EXPOSITION, Wisconsin, 1988. SAE Technical Paper Series 881280.

LUCCA, A. A.; MARQUEZ, F. S. (1993). Desenvolvimento de um chasis de ônibus urbano. In: CONGRESSO E EXPOSIÇÃO INTERNACIONAIS DE TECNOLOGIA DA MOBILIDADE, 2, São Paulo, 1993. SAE Technical Paper Series 931626.

MATHUES, T. P. (1994). ABS extending the range. SAE Technical Paper Series 940829. 
MATSUMOTO, S.; YAMAGUCHI, H.; INOUE, H. YASUNO, Y. (1992). Improvement of vehicle dynamics through braking force distribution control. SAE Technical Paper Series 920645.

MELLO, M. T.; SANTANA, M. G.; SOUZA, L. M.; OLIVEIRA, P. C. S.; VENTURA, M. L.; STAMPI, C.; TUFIK, S. (2000). Sleep patterns and sleeprelated complains of Brazilian interstate bus drivers. Brazilian journal of medical and biological research, v. 33, p. 71-77.

MOURA, L. F. M.; JERONYMO, C. E.; SILVA, J. B. C. (1994). Solução numérica de problemas de transferência de calor pelo método de elementos finitos baseado em volumes de controle. RBCM - Journal of the brazilian society mechanical sciences, v. 16, n. 1, p. 35-50.

NEWCOMB, T. P.; SPURR, R. T. (1967). Braking of road vehicles. London, Chapman and Hall Ltd.

NINA, A. P. (1992). O uso de sistemas de aquisição e estímulo de dados baseados em computadores industriais na indústria automobilística. In: CONGRESSO E EXPOSIÇÃO INTERNACIONAIS DE TECNOLOGIA DA MOBILIDADE, 1, São Paulo, 1992. SAE Technical Paper Series 921503.

OPPENHEIMER, P. (1988). Comparing stopping capability of cars with and without antilock braking systems (ABS). SAE Technical Paper Series 880324.

ÖZISIK, M. N. (1985). Transferência de calor - um texto básico. Traduzido por Luiz de Oliveira. Rio de Janeiro, Guanabara Koogan S.A

ÖZISIK, M. N. (1988). Inverse heat conduction problems. Revista brasileira de ciências mecânicas, v. 10, n. 4, p. 303-321. 
OWEN, J. M.; HAYNES, C. M.; BAYLEY, F. J. (1974). Heat transfer from an aircolled rotating disk. Proceedings of the Royal society of London, series A, mathematical and physical sciences, v. 336, n. 1607, p. 453-473, feb.

PACHECO, P. M. C. L.; HUBSCHER, F. P.; MATTOS, H. C. (1993). High temperature lifetime prediction in metallic materials subjected to cyclic loadings. RBCM- Journal of the brazilian society mechanical sciences, v. 15, n. 1, p. 5464.

PALKOVICS, L.; EL-GINDY, M. (1996).Examination of different control strategies of heavy vehicle performance. Journal of dynamic systems, measurement and control, v. 118, p. 489-497, sept.

PETERSEN, E. HESSE, K. H.; KAESS, H.; LINDEMANN, K. (1990). A new ABS with integral automatic traction control for air-braked trucks an buses. SAE Transactions, v. 99, n. 2, p. 688-703. SAE Technical Paper Series 902210.

PINHEIRO, M. (1995). Um século do ônibus motorizado. Tecnologia Automotiva, n.1, p.20-25.

POHL, L.; RIBEIRO, J. L. D.; GIL, W. J.; FAGUNDES, M.; CALCAGNOTTO, J. (1999). Modelos de desempenho aplicados ao estudo da confiabilidade de componentes automotivos. In: CONGRESSO E EXPOSIÇÃO INTERNACIONAIS DE TECNOLOGIA DA MOBILIDADE, 8, São Paulo, 1999. SAE Technical Paper Series 1999-01-3073.

RADLINSKI, R. W. (1989). Heavy vehicle braking - U.S. versus Europe. SAE Technical Paper Series 892504.

RAMACHANDRA RAO, V. T. V. S.; RAMASUBRAMANIAN, H.; SEETHARAMU, K. N. (1989). Modeling of temperature distribution in a brake 
drum using finite element method. Indian Journal of Technology, v. 27, p. 417424 , sept.

RANDHAWA, S. U.; MILLER, S. G.; BELL, C. A., MONTAGNE, P. E. (1998). A study of commercial vehicle safety alliance's out-of-service criteria. Accid. anal. and prev., v. 30, n.1, p.61-67.

RATH, H.; KNECHTGES, J. (1995). Effective active safety to reduce road accidents. . SAE Technical Paper Series 950761.

RELATÓRIO TÉCNICO MERCEDES-BENZ, Transmissão térmica convectiva a freios a disco. RT n. 94-083.

RELATÓRIO TÉCNICO MERCEDES-BENZ, Fluxo de ar em canais de refrigeração de freios a disco. RT n. 94-084.

RINEK, L. M.; COWAN, C. W. (1995). United States passenger car brake history. Automotive Engineering, v.103, n.7, p.37-41, July.

ROMANO, R. A.; STONER, J. W.; EVANS, D. F. (1991). Real time vehicle dynamics simulation: enabling tool for fundamental human factors research. Vehicle dynamics and electronic controlled suspensions. SP-861. SAE Technical Paper Series 910237.

RUNCHAL, A. K. (1972). Convergence and accuracy of three finite difference schemes for a two-dimensional conduction and convection problem. International jounal for numerical methods in engineering, v. 4, p. 541-550.

RUSSO, V. A. F.; BRESCIANI F., E. (1992). Função de pesquisa e planejamento estratégico. In: CONGRESSO E EXPOSIÇÃO INTERNACIONAIS DE TECNOLOGIA DA MOBILIDADE, 1, São Paulo, 1992. SAE Technical Paper Series 921529. 
RUSSO, V. A. F.; BRESCIANI F., E. (1993). Tratamento sistêmico de um programa de pesquisa para empresa industrial no setor de autopeças. In: CONGRESSO E EXPOSIÇÃO INTERNACIONAIS DE TECNOLOGIA DA MOBILIDADE, 2, São Paulo, 1993. SAE Technical Paper Series 931640.

SALMONI, R. (1966). Transmissão de calor. São Paulo, Mestre Jou.

SANTOS JÚNIOR, A. A. (1996). Determinação do coeficiente global de transferência de calor em rodas ferroviárias. 122p. Campinas. Tese (Doutorado) Faculdade de Engenharia Mecânica - Universidade de Campinas.

SCHENK, D. E.; WELLS, R. L.; MILLER, J. E. (1995). Intelligent braking for current and future vehicles. SAE Technical Paper Series 950762.

SCHWEITZER, N.; APTER, Y.; PARUSH, A.; LIEBERMANN, D. G., BEMDAVID, G. (1995). A field study on braking responses during driving. Ergonomics, v.38, n.9, p.1903-1910.

SEBAALY, P. E. (1992). Pavement damage as related to tires, pressures, axle loads, and configurations. In: VEHICLE, TIRE, PAVEMENT INTERFACE, Philadelphia, 1992, p.54-68.

SHERIDAN, D. C.; CHANG. H. H. (1993). A requirements driven design methodology for a vehicle brake system. ABS/TCS and brake technology. SP-953. SAE Technical Paper Series 930800.

SHERIF, H. A. (1991). On the design of anti-squeal friction pads for disc brakes. In: INTERNATIONAL CONGRESS AND EXPOSITION, Detroit, 1991. SAE Technical Paper Series 910575. 
SHIBATA, K.; GOTO, A.; YOSHIDA, S.; AZUMA, Y.; NAKAMURA, K. (1993). Development of brake friction material. ABS/TCS and brake technology. SP-953. SAE Technical Paper Series 930806.

SILVA, S. L. (1994). Organização e desempenho de novos produtos na indústria automobilística brasileira. In: CONGRESSO E EXPOSIÇÃO INTERNACIONAIS DE TECNOLOGIA DA MOBILIDADE, 3, São Paulo, 1994. SAE Technical Paper Series 942429.

SINGH, M.; BRIDGENS, B. (1996). Design of a brake by wire system using OOA. SAE Technical Paper Series 960992.

SIQUEIRA, L. P.; OLIVEIRA, A. C.; AGU, H. C. (2001). Formulação de critério para limites de aceitação de micro-trincas em tambores de freio. In: INTERNATIONAL BRAKE COLLOQUIUM, 5., p.14-17.

SOHN, S. Y.; STEPLEMAN, R. (1998). Meta-analysis on total braking time. Ergonomics, v.41, aug, p.1129-1140.

STANCATO, F.; ONUSIC, H.; ANTONELLI, R. A.; AVILA, P. U. (1992). Análise numérica e experimental de cargas térmicas em um ônibus rodoviário. In: CONGRESSO E EXPOSIÇÃO INTERNACIONAIS DE TECNOLOGIA DA MOBILIDADE, 1, São Paulo, 1992. SAE Technical Paper Series 921474.

STRINGHAM, W.; JANK, P.; PFEIFER, J.; WANG, A. (1993). Brake roughness disc brake torque variation, rotor distortion and vehicle response. ABS/TCS and brake technology. SP-953. SAE Technical Paper Series 930803.

TEICHNER, W. H. (1954). Recent studies in simple reaction time. Psychological bulletin, vol.51, p.128-149. 
TIROVIC, M.; DAY, A. J. (1991). Disc brake interface pressure distributions. Journal of automobile engineering, v.205, n.2, p.137-146.

TODOROVIC, J.; DUBOKA, C.; ARSENIC, Z. (1995). Braking system quality for customer satisfaction. SAE Technical Paper Series 950790.

TRICHÊS JR., M.; JORDAN, R.; GERGES, S. N. Y.; TOUSSI, S. (2001). Análise modal de pastilhas de freio considerando os efeitos do amortecimento e da temperatura. In: INTERNATIONAL BRAKE COLLOQUIUM, 5., p.52-58.

VAUGHAN, C. M.; GILHAM, S.; CHEW, J. W. Numerical solutions of rotating disc flows using a non-linear multigrid algorithm. Proc. $6^{\text {th }}$ Int. Conf. Numer. Meth. Laminar and Turbulent Flow.

VON GLASNER, E. C.; BERGMANN, H.; MARWITZ, H.; POVEL, R. (2000). Intelligent braking management for commercial vehicles. In: CONGRESSO E EXPOSIÇÃO INTERNACIONAIS DE TECNOLOGIA DA MOBILIDADE, 9, São Paulo, 2000. SAE Technical Paper Series 2000-01-3156.

WALTON, D. (1999). Examining the self-enhancement bias: professional truck driver's perceptions of speed, safety, skill and consideration. Transportation research Part F: Traffic psychology and behaviour, v.2, p.91-113, jun.

WANG, N. (1994). The evolution of the pad guided disc brake caliper. SAE Technical Paper Series 940332.

WEDLIN, J.; BANE, O.; TILLBACK, L. R. (1992). Combining properties for driving pleasure and driving safety: a challenge for the chassis engineer. SAE Technical Paper Series 921595. 
WILLIAMS, A. R. (1990). A review of tire traction. In: VEHICLE, TIRE, PAVEMENT INTERFACE. Philadelphia, J. J. Henry and J. C. Wambold. American Society for Testing and Materials, ASTM STP 1225, p 125-148.

WINKLER, C. B. (1976). Predicting the braking performance of trucks and tractortrailers. Highway Safety Research Institute, University of Michigan, Part III Technical Report.

WOOD, P.; AMOS, D. (1994). Increased braking power for mine winder applications. Mining technology, n.876, jun., p.171-175.

WREDE, J.; DECKER, H. (1992). Brake by wire for commercial vehicles. SAE Technical Paper Series 922489.

ZAGRODZKI, P. (1991). Influence of design and material factors on thermal stresses in multiple disc wet clutches and brakes. Journal of commercial vehicles, v.100, n.2, p.395-405. SAE Technical Paper Series 911883.

ZIENKIEWICZ, O. C.; TAYLOR, R. L. (1989). The finite element method. 4 ed. London, McGraw-Hill. 


\section{APÊNDICE 1}

Configuração esquemática do programa de simulação veicular. 


\section{APÊNDICE 2}

Relatório de inspeção e calibração dos termopares utilizados. 


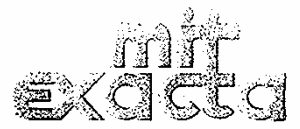

\section{RELATÓRIO DE INSPECÁO DE TERMOPAR 20110K32}

\section{Cliente: Daimler Chrysler do Brasil Ltda}

Ordem Interna: 0179/02

PROJETO MERCEDES BENZ: FSK

RESPONSÁVEL: Paulo Ávila

Objetivo:

Inspeção Visual, Testes de Isolação e Funcionabilidade.

Peças Ensaiadas:

Sensor tipo K (CR-AL) bainha AISI 316, fornecedor BICC Pynotenax - Canadá elemento simples, isolação mineral $1,0 \mathrm{~mm} \times 1000 \mathrm{~mm}$ de comprimento, com pote cabo de extensão tipo $\mathrm{K} 3 \times 12 \mathrm{~mm}$ Awg, comprimento, 50mm isolação Tefion com conector compensado macho grande e com presilhas, MARLIN - USA.

\section{Quantidade:}

50 peças

Data da realização do ensaio:

29 de Janeiro de 2002

Ambiente dos testes: Laboratório

Temperatura do ambiente do laboratório: $21^{\circ} \mathrm{C}+1-1^{\circ} \mathrm{C}$

Pressẫo: $706 \mathrm{~mm} \mathrm{Hg}$

\section{Testes realizados:}

- Inspeção Visual (Conforme ASTM E585)

Foram verificados a aparência do termopar, quanto a oxidação do conec-

tor e da bainha e a integridade da isolação externa do cabo de extensâo e

do conector.

- Teste de Isolação (Conforme ASTM E585)

A isolaçæo elétrica, entre a bainha e o conector, foi medida em $100 \mathrm{VCC}$, que

é tensão indicada para os termopares com bainha DE: $1,0 \mathrm{~mm}$.

- Incerteza: $0,3 \% \mathrm{C}$

- Profundidade de imersão do termopar: $70 \%$ do comprimento do termopar

- Teste de Funcionabilidade (Conforme ASTM E230/1992)

$$
\text { (Ver tabela) }
$$


in

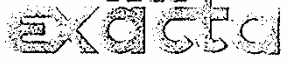

Tabela:

\begin{tabular}{|c|c|c|c|c|c|c|c|c|c|}
\hline TAG N $\mathbf{N}^{\circ}$ & $\begin{array}{r}\text { VALOR } \\
\text { REAL } \\
{ }^{\circ} \mathrm{C}\end{array}$ & $\begin{array}{r}\text { VALOR } \\
\text { INDICADO } \\
{ }^{\circ} \mathrm{C}\end{array}$ & $\begin{array}{r}\text { DESVIO } \\
{ }^{\circ} \mathrm{C}\end{array}$ & $\begin{array}{r}\text { VALOR } \\
\text { REAL } \\
{ }^{\circ} \mathrm{C}\end{array}$ & $\begin{array}{r}\text { VALOR } \\
\text { INDICADO } \\
{ }^{\circ} \mathrm{C} \\
\end{array}$ & $\begin{array}{r}\text { DESVIO } \\
{ }^{\circ} \mathrm{C}\end{array}$ & $\begin{array}{r}\text { VALOR } \\
\text { REAL } \\
{ }^{\circ} \mathrm{C}\end{array}$ & $\begin{array}{r}\text { VALOR } \\
\text { INDICADO } \\
{ }^{\circ} \mathrm{C}\end{array}$ & $\begin{array}{r}\text { DESVIO } \\
{ }^{\circ} \mathrm{C}\end{array}$ \\
\hline 01 & 100 & 100.35 & 0.35 & 200 & 200.30 & 0.30 & 300 & 300.25 & 0.25 \\
\hline 02 & 100 & 100.40 & 0.40 & 200 & 200.50 & 0.50 & 300 & 300.55 & 0.55 \\
\hline 03 & 100 & 100.30 & 0.30 & 200 & 200.35 & 0.35 & 300 & 300.40 & 0.40 \\
\hline 04 & 100 & 100.60 & 0.60 & 200 & 200.55 & 0.55 & 300 & 300.50 & 0.50 \\
\hline 05 & 100 & 100.45 & 0.45 & 200 & 200.35 & 0.35 & 300 & 300.40 & 0.40 \\
\hline 06 & 100 & 100.25 & 0.25 & 200 & 200.60 & 0.60 & 300 & 300.55 & 0.55 \\
\hline 07 & 100 & 100.35 & 0.35 & 200 & 200.60 & 0.60 & 300 & 300.25 & 0.25 \\
\hline 08 & 100 & 100.40 & 0.40 & 200 & 200.35 & 0.35 & 300 & 300.40 & 0.40 \\
\hline 09 & 100 & 100.60 & 0.60 & 200 & 200.25 & 0.25 & 300 & 300.50 & 0.50 \\
\hline 10 & 100 & 100.25 & 0.25 & 200 & 200.20 & 0.20 & 300 & 300.30 & 0.30 \\
\hline 11 & 100 & 100.20 & 0.20 & 200 & 200.25 & 0.25 & 300 & 300.35 & 0.35 \\
\hline 12 & 100 & 100.30 & 0.30 & 200 & 200.40 & 0.40 & 300 & 300.45 & 0.45 \\
\hline 13 & 100 & 100.35 & 0.35 & 200 & 200.40 & 0.40 & 300 & 300.45 & 0.45 \\
\hline 14 & 100 & 100.60 & 0.60 & 200 & 200.55 & 0.55 & 300 & 300.50 & 0.50 \\
\hline 15 & 100 & 100.20 & 0.20 & 200 & 200.30 & 0.30 & 300 & 300.25 & 0.25 \\
\hline 16 & 100 & 100.55 & 0.55 & 200 & 200.60 & 0.60 & 300 & 300.50 & 0.50 \\
\hline 17 & 100 & 100.25 & 0.25 & 200 & 200.35 & 0.35 & 300 & 300.30 & 0.30 \\
\hline 18 & 100 & 100,45 & 0.45 & 200 & 200.50 & 0.50 & 300 & 300,40 & 0.40 \\
\hline 19 & 100 & 100.20 & 0.20 & 200 & 200.25 & 0.25 & 300 & 300.30 & 0.30 \\
\hline 20 & 100 & 100.25 & 0.25 & 200 & 200.60 & 0.60 & 300 & 300.50 & 0.50 \\
\hline 21 & 100 & 100.60 & 0.60 & 200 & 200.50 & 0.50 & 300 & 300.55 & 0.55 \\
\hline 22 & 100 & 100.20 & 0.20 & 200 & 200.50 & 0.50 & 300 & 300.25 & 0.25 \\
\hline 23 & 100 & 100.50 & 0.50 & 200 & 200.60 & 0.60 & 300 & 300.35 & 0.35 \\
\hline 24 & 100 & 100.35 & 0.35 & 200 & 200.50 & 0.50 & 300 & 300.40 & 0.40 \\
\hline 25 & 100 & 100.55 & 0.55 & 200 & 200.25 & 0.25 & 300 & 300.45 & 0.45 \\
\hline 26 & 100 & 100.55 & 0.55 & 200 & 200,45 & 0.45 & 300 & 300.60 & 0.60 \\
\hline 27 & 100 & 100.60 & 0.60 & 200 & 200.50 & 0.50 & 300 & 300.55 & 0.55 \\
\hline 28 & 100 & 100.35 & 0.35 & 200 & 200.40 & 0.40 & 300 & 300.45 & 0.45 \\
\hline 29 & 100 & 100.55 & 0.55 & 200 & 200.50 & 0.50 & 300 & 300.55 & 0.55 \\
\hline 30 & 100 & 100.20 & 0.20 & 200 & 200.25 & 0.25 & 300 & 300.30 & 0.30 \\
\hline 31 & 100 & 100.40 & 0.40 & 200 & 200.55 & 0.55 & 300 & 300.50 & 0.50 \\
\hline 32 & 100 & 100.55 & 0.55 & 200 & 200.60 & 0.60 & 300 & 300.50 & 0.50 \\
\hline 33 & 100 & 100.45 & 0,45 & 200 & 200.35 & 0.35 & 300 & 300.40 & 0.40 \\
\hline 34 & 100 & 100.35 & 0.35 & 200 & 200.40 & 0.40 & 300 & 300.30 & 0.30 \\
\hline 35 & 100 & 100.60 & 0.60 & 200 & 200.55 & 0.55 & 300 & 300.50 & 0.50 \\
\hline 36 & 100 & 100.25 & 0.25 & 200 & 200.30 & 0.30 & 300 & 300.20 & 0.20 \\
\hline 37 & 100 & 100.25 & 0.25 & 200 & 200.35 & 0.35 & 300 & 300.20 & 0.20 \\
\hline 38 & 100 & 100.55 & 0.55 & 200 & 200.50 & 0.50 & 300 & 300.45 & 0.45 \\
\hline 39 & 100 & 100,30 & 0.30 & 200 & 200,40 & 0.40 & 300 & 300.35 & 0.35 \\
\hline 40 & 100 & 100.55 & 0.55 & 200 & 200.25 & 0.25 & 300 & 300.35 & 0.35 \\
\hline
\end{tabular}

Mit-Exacta Indústria e Comércio de Instrumentos e Sistemas de Automação Ltda Av. Eng ${ }^{\circ}$. Caetano Álvares, 1553 - Casa Verde - CEP 02546-000 - São Paulo - SP PABX: (11) 3951-0020 - Fax: (11) 3951-0244 -E-mail: mitexacta@uol.com.br 


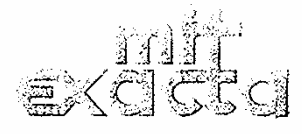

\begin{tabular}{|c|r|r|r|r|r|r|r|r|r|}
\hline TAG N & $\begin{array}{r}\text { VALOR } \\
\text { REAC } \\
{ }^{\circ} \mathrm{C}\end{array}$ & $\begin{array}{r}\text { VALOR } \\
\text { INDICADO }\end{array}$ & $\begin{array}{r}\text { DESVIO } \\
{ }^{\circ} \mathrm{C}\end{array}$ & $\begin{array}{r}\text { VALOR } \\
\text { REAL }\end{array}$ & $\begin{array}{r}\text { VALOR } \\
\text { INDICADO }\end{array}$ & $\begin{array}{r}\text { DESVIO } \\
{ }^{\circ} \mathrm{C}\end{array}$ & $\begin{array}{r}\text { VALOR } \\
\text { REAL } \\
{ }^{\circ} \mathrm{C}\end{array}$ & $\begin{array}{r}\text { VALOR } \\
\text { INDICADO }\end{array}$ & $\begin{array}{r}\text { DESVIO } \\
{ }^{\circ} \mathrm{C}\end{array}$ \\
\hline 41 & 100 & 100.20 & $\mathbf{0 . 2 0}$ & 200 & 200.30 & 0.30 & 300 & 300.35 & 0.35 \\
\hline 42 & 100 & 100.50 & 0.50 & 200 & 200.45 & 0.45 & 300 & 300.60 & 0.60 \\
\hline 43 & 100 & 100.20 & 0.20 & 200 & 200.30 & 0.30 & 300 & 300.25 & 0.25 \\
\hline 44 & 100 & 100.55 & 0.55 & 200 & 200.35 & 0.35 & 300 & 300.40 & 0.40 \\
\hline 45 & 100 & 100.45 & 0.45 & 200 & 200.40 & 0.40 & 300 & 300.55 & 0.55 \\
\hline 46 & 100 & 100.35 & 0.35 & 200 & 200.55 & 0.55 & 300 & 300.25 & 0.25 \\
\hline 47 & 100 & 100.25 & 0.25 & 200 & 200.45 & 0.45 & 300 & 300.40 & 0.40 \\
\hline 48 & 100 & 100.60 & 0.60 & 200 & 200.50 & 0.50 & 300 & 300.55 & 0.55 \\
\hline 49 & 100 & 100.40 & 0.40 & 200 & 200.50 & 0.50 & 300 & 300.55 & 0.55 \\
\hline 50 & 100 & 100.60 & 0.60 & 200 & 200.55 & 0.55 & 300 & 300.45 & 0.45 \\
\hline
\end{tabular}

- Conclusẩo:

Os termopares testados, foram liberados com as peças identificadas, número de relatório $20110 \mathrm{~K} 32$

Os instrumentos utilizados neste relatório de inspeção, possuem certificado de calibração rastreável e com planejamento de reaferição regulares tendo como referência laboratórios de calibração independentes.

\begin{tabular}{|c|c|c|c|c|c|c|}
\hline PADRĀO & $\begin{array}{l}\text { DATA DE } \\
\text { CALIBRAÇÃO }\end{array}$ & $\begin{array}{l}\text { DATA DE } \\
\text { RECALIBRAÇÃO }\end{array}$ & $\begin{array}{l}N^{\circ} \\
\text { CERTIICAD } \\
0\end{array}$ & MARCA & $\begin{array}{l}\text { CADEIA DE } \\
\text { RASTREABILIDADE }\end{array}$ & NORMA \\
\hline$P T-100$ & $25 / 09 / 2001$ & 03.2002 & LTR $3436 / 02$ & MIT EXACTA & $\mathrm{RBC}$ & ASTM- 230 \\
\hline $\begin{array}{l}\text { Multímetro } \\
\text { HP } 3457 \text { A }\end{array}$ & $22 / 10 / 2001$ & 10.2002 & 40940 & $\begin{array}{l}\text { HEWLETT } \\
\text { PACKARD }\end{array}$ & $\begin{array}{l}\text { 1. IPT/RBC } \\
\text { 2. INMETRO }\end{array}$ & 95NP60PR09X \\
\hline
\end{tabular}

A reprodução por inteiro deste relatório só poderá ser feita através de aprovação por escrito da MIT EXACTA. 


\section{GLOSSÁRIO}

$\underline{\text { Fade }}$ - é o termo utilizado para designar o efeito da perda de atrito da lona ou pastilha, provocada pelo excesso de calor gerado durante as frenagens.

Fator de freio - é a razão entre a força de frenagem produzida no contato entre pastilhas e disco e a força tangencial aplicada para comprimir as pastilhas contra o disco.

Freio motor - sua atuação ocorre no sistema de escapamento do motor, por obstrução parcial da saída dos gases, através de uma borboleta. Desta forma, o motor oferece uma resistência ao deslocamento do veículo.

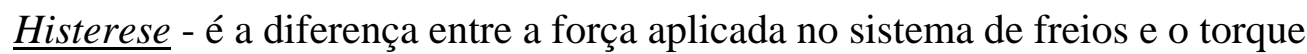
constante de frenagem. 